\title{
ESTUDO CEFALOMÉTRICO DAS ALTERAÇÕES DAS ALTURAS FACIAIS ANTERIOR E POSTERIOR EM PACIENTES NIPO-BRASILEIROS COM MÁS OCLUSÕES DE CLASSE I E CLASSE II, 1ª DIVISÃO DE ANGLE, TRATADOS ORTODONTICAMENTE
}

\author{
SANDRA MÁRCIA HAYASAKI
}

Dissertação apresentada à Faculdade de Odontologia de Bauru, da Universidade de São Paulo, como parte dos requisitos para obtenção do título de Mestre em Odontologia, área de Ortodontia.

(Edição Revisada)

BAURU 


\title{
ESTUDO CEFALOMÉTRICO DAS ALTERAÇÕES DAS ALTURAS FACIAIS ANTERIOR E POSTERIOR EM PACIENTES NIPO-BRASILEIROS COM MÁS OCLUSÕES DE CLASSE I E CLASSE II, 1ª DIVISÃO DE ANGLE, TRATADOS ORTODONTICAMENTE
}

\author{
SANDRA MÁRCIA HAYASAKI
}

Dissertação apresentada à Faculdade de Odontologia de Bauru, da Universidade de São Paulo, como parte dos requisitos para obtenção do título de Mestre em Odontologia, área de Ortodontia.

(Edição Revisada)

Orientador: Prof. Dr. José Fernando Castanha Henriques

BAURU 


\begin{tabular}{|l|}
\hline Hayasaki, Sandra Márcia \\
Estudo cefalométrico das alterações das alturas faciais anterior e posterior \\
em pacientes nipo-brasileiros com más oclusões de classe I e classe II, 1 \\
divisão de Angle, tratados ortodonticamente / Sandra Márcia Hayasaki - \\
Bauru, 2002. \\
197p. + apêndices: il.; $29,7 \mathrm{~cm}$. \\
Dissertação. (Mestrado) - Faculdade de Odontologia de Bauru, USP. \\
Orientador: Prof. Dr. José Fernando Castanha Henriques.
\end{tabular}

Autorizo, exclusivamente para fins acadêmicos e científicos, a reprodução total ou parcial desta dissertação, por processos fotocopiadores e/ou meios eletrônicos.

Assinatura da autora:

Data:

Projeto de pesquisa aprovado pelo Comitê de Ética em Pesquisa da Faculdade de Odontologia de Bauru - Universidade de São Paulo na reunião do dia 24 de fevereiro de 2000. 


\section{DADOS CURRICULARES \\ SANDRA MÁRCIA HAYASAKI}

19 de janeiro de 1973

Nascimento

Ribeirão Preto - SP

1993-1996

Curso de Graduação em

Odontologia- Faculdade de

Odontologia de Bauru -

Universidade de São Paulo (USP).

1997-1999

Curso de Aperfeiçoamento em Ortodontia pela APCD- Regional Bauru.

2000-2002

Curso de Pós-Graduação em Odontologia, área de Ortodontia, ao nível de Mestrado, pela Faculdade de Odontologia de BauruUniversidade de São Paulo (USP).

ASSOCIAÇÕES APCD - Associação Paulista de Cirurgiões-Dentistas 
“O futuro pertence àqueles que acreditam na beleza dos seus sonhos".

Eleanor Roosevelt 
"Quando Sócrates conheceu a resposta do oráculo que o proclamava o homem mais sábio de todos, surpreendido, andou a interrogar os que pareciam sábios e deu-se conta de que a sabedoria deles era nula. Compreendeu, então, o significado do oráculo: nenhum homem sabe verdadeiramente nada, mas é sábio quem sabe que não sabe, não quem se ilude com o saber e ignora, assim, até a sua própria ignorância. E na realidade só quem sabe que não sabe procura saber, enquanto os que crêem estar na posse de um saber fictício não são capazes de investigação, não se preocupam consigo mesmos e permanecem irremediavelmente afastados da verdade e da virtude".

ABBAGNANO, 1976. 
Dedico este trabalho

A DEUS, pelo infinito Amor e Orientação em todos os momentos de minha vida, principalmente nos mais difíceis e por me proporcionar saúde e disposição para trabalhar e estudar;

Aos meus pais, Massaro e Irene, pelo carinho, apoio e incentivo em benefício da minha formação humana e profissional;

Ao meu querido filho, André Luís, pelo amor, companheirismo e amizade.

Minha eterna gratidão!!! 
Meu reconhecimento e agradecimento especial

\section{Ao Professor Doutor \\ JOSÉ FERNANDO CASTANHA HENRIQUES,}

Orientador deste trabalho, pela confiança em mim depositada, concedendo-me uma oportunidade única para meu tão sonhado ingresso no Curso de Mestrado, além de seu constante apoio, orientação e amizade ao longo desses cinco anos de convivência. Seu incentivo e ensinamentos foram essenciais para a minha formação profissional! Muito obrigada!!! 
Ao Prof. Dr. José Mondelli, pelo exemplo de amor e dedicação à vida acadêmica e pela honra de sua amizade. 
Agradecimentos especiais

Ao Prof. Dr. Décio Rodrigues Martins, pelos sábios ensinamentos transmitidos durante todo o curso de Pós-graduação.

Ao Coordenador do Curso de Pós-graduação em Ortodontia, ao nível de Mestrado, Prof. Dr. Guilherme Janson, pela oportunidade concedida e pelos ensinamentos que contribuíram para minha formação ortodôntica.

Aos demais Professores da Disciplina de Ortodontia, Prof. Dr. Marcos Roberto de Freitas, Prof. Dr. Renato Rodrigues de Almeida, Prof. Dr. Arnaldo Pinzan, pela amizade, ensinamentos, e valiosa contribuição para minha formação profissional.

Aos Profs. Dr. Deocleciano Carvalho e Dr. Luciano da Silva Carvalho, pela oportunidade em utilizar as documentações pertencentes aos seus pacientes, material fundamental para a realização deste trabalho.

Aos Profs. Omar Gabriel da Silva Filho e Terumi Okada, por me concederem gentilmente parte da amostra utilizada nesta pesquisa.

Ao Prof. Dr. Rumio Taga e demais professores e funcionários do Departamento de Histologia da Faculdade de Odontologia de Bauru- USP, pela amizade, pela convivência durante minha fase acadêmica, por incentivarem minha carreira docente e pela orientação e oportunidade de desenvolvimento da pesquisa de iniciação científica realizada durante o curso de graduação. 
À Prof. Dra. Denise Tostes pela amizade, pela orientação profissional e pela confiança em mim depositada.

Ao Prof. José Roberto Lauris, pelos esclarecimentos estatísticos.

Aos amigos do Curso de Mestrado em Ortodontia, Adriana, Célia, Cláudia, Daniele, Denise, Fábio, Fabrício, Fernanda, José Eduardo, José Norberto, Karina, Maria Fernanda e Rejane, pelos momentos agradáveis e principalmente pelo árduo caminho que, juntos, conseguimos superar.

Aos amigos do Novo Curso de Mestrado em Ortodontia, Analu, Celso, Cristina Yuka, Dani, Karina, Leniana, Rodrigo e Ângela.

Aos amigos do Curso de Doutorado em Ortodontia, Ana Carla, Ana Cláudia, Dani Garib, Danilo, Fausto, Karina Cruz, Karyna Valle, Paulo, Renata e Roberto pela convivência agradável.

Aos colegas do antigo Curso de Doutorado, Acácio, Alexandre, Liliana, Márcio, Maria Helena e Ricardo, pelo convívio, amizade e orientação de trabalhos científicos.

À minha grande amiga Graziela De Luca Canto, uma das principais responsáveis por minha formação ortodôntica, pelo apoio e incentivo constantes.

Ao meu amigo Ricardo Takahashi, pelo companheirismo, pelo grande incentivo profissional e pela orientação dos trabalhos apresentados. 
À Maria Helena Vasconcelos, pela orientação na utilização do programa cefalométrico.

Aos meus amigos, Linda, Cláudia, Cristiane, Renata Baiana, Fernanda, Ana Paula, Dani Rios, Heitor, Rosa, Valéria, Maíta, Luciana Reis, Milena, Patrícia, Marco, Hugo e Dudu, pelos momentos felizes, pela verdadeira amizade e apoio constantes.

À minha madrinha D. Aparecida Pimentel (em memória), pelo grande incentivo à minha carreira.

Aos meus colegas da Multclínica, Josther e Mariângela, pela convivência agradável e pela amizade.

Aos meus colegas de Santa Cruz, Sílvia Helena, Larissa e Paulo.

E a você, Eduardo, pela paciência, pela compreensão, por conseguirmos juntos superar os momentos mais difíceis, pelo apoio, por sua amizade, seu carinho e principalmente pelo tempo que dispensou na elaboração das figuras, tabelas e na formatação deste trabalho. 


\section{Agradeço ainda}

Aos funcionários da Disciplina de Ortodontia, Verinha, Tia Maria, Cris e Sérgio, pela colaboração e amizade.

Aos funcionários da ACOPEN, Sônia, Simone e César, pela cordialidade com que sempre me receberam.

Aos funcionários da biblioteca, em especial à Cibele, Vera, Rita, Ademir e César, pela atenção e serviços prestados.

Ao amigo Daniel (Bonné) pela colaboração em vários aspectos do campo da informática e elaboração das figuras.

Aos funcionários da Pós-graduação, em especial à Geane e Aurélio, pela atenção e simpatia com que sempre me receberam.

Aos pacientes, que muito contribuíram para o meu enriquecimento profissional.

Enfim, a todos aqueles que contribuíram, direta ou indiretamente, para meu desenvolvimento profissional e para a realização deste trabalho. 


\section{Agradecimentos administrativos}

Ao Prof. Dr. Aymar Pavarini, Diretor da Faculdade de Odontologia de Bauru- USP.

Ao Prof. Dr. Luís Fernando Pegoraro, Presidente da Comissão de Pósgraduação da Faculdade de Odontologia de Bauru- USP.

À Fundação de Amparo à Pesquisa do Estado de São Paulo (FAPESP), pela concessão da bolsa de estudo. 


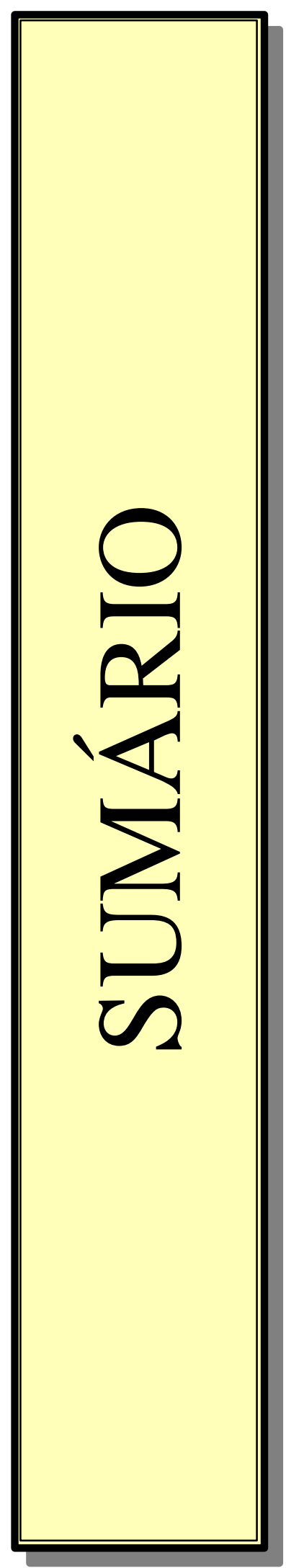




\section{SUMÁRIO}

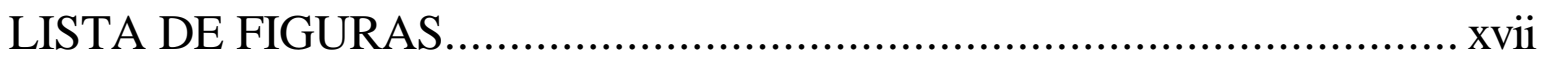

LISTA DE TABELAS .....................................................................

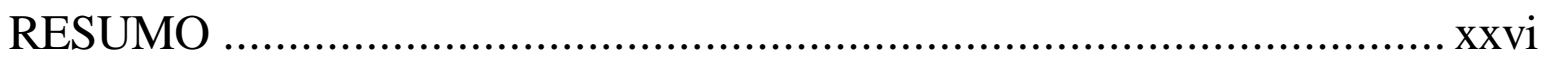

1. INTRODUÇÃ

2. REVISÃO DE LITERATURA.........................................................

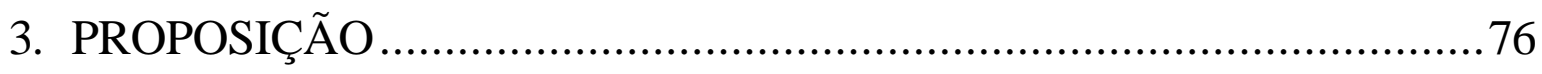

4. MATERIAL E MÉTODOS......................................................... 78

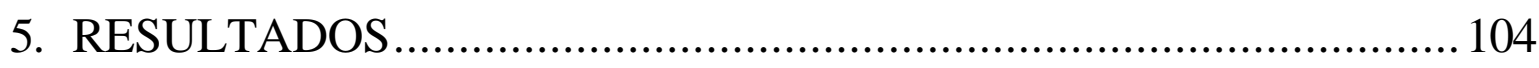

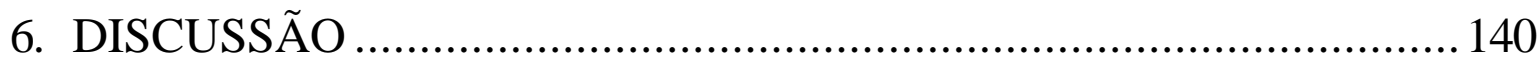

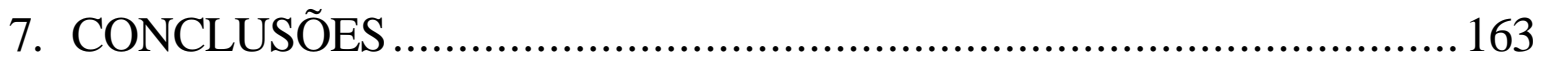

REFERÊNCIAS BIBLIOGRÁFICAS ........................................... 166

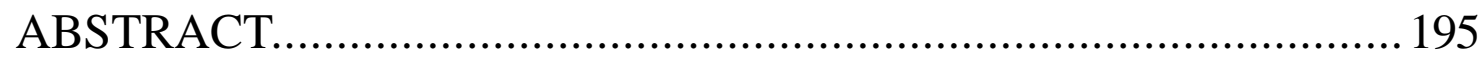

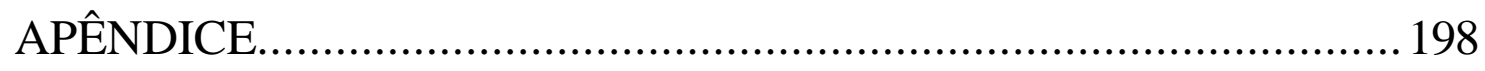




\section{LISTA DE FIGURAS}

FIGURA 4.1 - Delimitação do desenho anatômico......................................87

FIGURA 4.2 - Pontos cefalométricos utilizados.........................................90

FIGURA 4.3 - Linhas e planos de referência utilizados ..............................92

FIGURA 4.4 - Grandezas cefalométricas angulares ...................................94

FIGURA 4.5 - Grandezas cefalométricas lineares dentoalveolares ...............96

FIGURA 4.6 - Grandezas cefalométricas lineares esqueléticas ...................98

FIGURA 5.1 - Angulação do plano mandibular em relação ao plano de Francfort. Valores médios iniciais e finais para cada grupo

FIGURA 5.2 - Angulação do plano mandibular em relação à base do crânio. Valores médios iniciais e finais para cada grupo.

FIGURA 5.3 - Distância entre a ponta de cúspide mesial do primeiro molar superior permanente e o Plano de Francfort. Valores médios iniciais e finais para cada grupo. 
FIGURA 5.4 - Distância entre a ponta de cúspide mesial do primeiro molar superior permanente e o plano palatino. Valores médios iniciais e finais para cada grupo.

FIGURA 5.5 - Distância entre a ponta de cúspide mesial do primeiro molar inferior permanente e o Plano Mandibular. Valores médios iniciais e finais para cada grupo.

FIGURA 5.6 - Distância horizontal entre a face distal do primeiro molar superior permanente e a linha PTV. Valores médios iniciais e finais para cada grupo. 133

FIGURA 5.7 - Distância horizontal entre a face distal do primeiro molar inferior permanente e a linha PTV. Valores médios iniciais e finais para cada grupo.

FIGURA 5.8 - Altura facial póstero-inferior. Valores médios iniciais e finais para cada grupo.

FIGURA 5.9 - Altura facial ântero-inferior segundo GEBECK \& MERRIFIELD. Valores médios iniciais e finais para cada grupo 135

FIGURA 5.10 - Índice de HORN. Proporção entre a medida PFH e a medida AFH. Valores médios iniciais e finais para cada grupo 
FIGURA 5.11 - Altura facial posterior total. Valores médios iniciais e finais para cada grupo............................................. 136

FIGURA 5.12 - Altura facial anterior total. Valores médios iniciais e

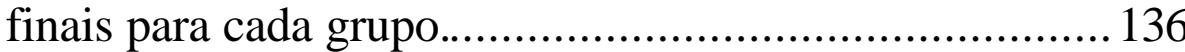

FIGURA 5.13 - Quociente de JARABAK. Proporção entre a altura facial posterior total e a altura facial anterior total. Valores médios iniciais e finais para cada grupo

FIGURA 5.14 - Altura facial ântero-superior. Valores médios iniciais e finais para cada grupo.

FIGURA 5.15 - Altura facial ântero-inferior. Valores médios iniciais e finais para cada grupo. 138

FIGURA 5.16 - Proporção entre a altura facial ântero-inferior e a altura facial anterior total. Valores médios iniciais e finais para cada grupo 138

FIGURA 5.17 - Proporção entre a altura facial ântero-inferior e a altura facial ântero-superior. Valores médios iniciais e finais para cada grupo

FIGURA 5.18 - Proporção entre a altura facial ântero-superior e a altura facial anterior total. Valores médios iniciais e finais para cada grupo 
FIGURA 6.1 - Alterações das medidas angulares esqueléticas.

FIGURA 6.2 - Medidas utilizadas no Índice de HORN. 148

FIGURA 6.3 - Alterações das alturas faciais póstero-inferior e ântero-inferior e do Índice de HORN

FIGURA 6.4 - Alterações das alturas faciais posterior e anterior e do Quociente de JARABAK.

FIGURA 6.5 - Alterações das proporções faciais anteriores. 153

FIGURA 6.6 -Alterações das distâncias entre a ponta de cúspide mesial do primeiro molar superior permanente e o plano de Francfort (CMS-Franc) e o plano palatino (CMS-PP). 154

FIGURA 6.7 - Alterações da distância entre a ponta de cúspide mesial do primeiro molar inferior permanente e o plano mandibular. 156

FIGURA 6.8 - Alterações das distâncias horizontais entre a face distal dos primeiros molares superior e inferior permanentes e a linha PTV. 


\section{LISTA DE TABELAS}

TABELA 4.1 - Características da amostra empregada. .80

TABELA 4.2 -Descrição das estruturas anatômicas constituintes do traçado cefalométrico .86

TABELA 4.3 - Descrição dos pontos cefalométricos utilizados .88

TABELA 4.4 - Descrição das linhas e planos utilizados 91

TABELA 4.5 - Descrição das grandezas cefalométricas angulares .93

TABELA 4.6 - Descrição das grandezas cefalométricas lineares dentoalveolares .95

TABELA 4.7 - Grandezas cefalométricas lineares esqueléticas .97

TABELA 4.8 - Proporções entre as medidas cefalométricas verticais esqueléticas .99

TABELA 4.9- Análise estatística para determinação da confiabilidade do método cefalométrico. Apresentação das médias (X) e desvio-padrão (DP) e do erro casual (Dalhberg- E) e erro sistemático (Teste "t" pareado) para os dois tempos realizados. 102 
TABELA 5.1 - Média das idades iniciais e finais dos jovens nos quatro grupos e o tempo de tratamento. 105

TABELA 5.2- Média das idades iniciais, finais e do tempo de tratamento dos jovens nos quatro grupos, divididos de acordo com o gênero. 106

TABELA 5.3 - Apresentação das alterações médias ocorridas durante o tratamento de pacientes do Grupo I 108

TABELA 5.4 - Apresentação das alterações médias ocorridas durante o tratamento de pacientes do Grupo II 110

TABELA 5.5- Apresentação das alterações médias ocorridas durante o tratamento de pacientes do Grupo III 112

TABELA 5.6- Apresentação das alterações médias ocorridas durante o tratamento de pacientes do Grupo IV 114

TABELA 5.7- Comparação entre os gêneros feminino e masculino das alterações médias ocorridas durante o tratamento do Grupo I 116

TABELA 5.8 -Comparação entre os gêneros feminino e masculino das alterações médias ocorridas durante o tratamento do Grupo II 118 
TABELA 5.9 -Comparação entre os gêneros feminino e masculino das alterações médias ocorridas durante o tratamento do Grupo III

TABELA 5.10 - Comparação entre os gêneros feminino e masculino das alterações médias ocorridas durante o tratamento do Grupo IV 122

TABELA 5.11 - Comparação entre os quatro grupos das alterações médias obtidas durante o tratamento (ANOVA) 125

TABELA 5.12 - Coeficiente de correlação de Pearson para verificar a correlação entre as alterações das medidas FMA, SN.GoGn e PFH, AFH, PFH/AFH, AFP, AFA, AFP/AFA, CMS-Franc, CMS-PP e CMI-PM para o Grupo I 127

TABELA 5.13 - Coeficiente de correlação de Pearson para verificar a correlação entre as alterações das medidas FMA, SN.GoGn e PFH, AFH, PFH/AFH, AFP, AFA, AFP/AFA, CMS-Franc, CMS-PP e CMI-PM para o Grupo II 127

TABELA 5.14 - Coeficiente de correlação de Pearson para verificar a correlação entre as alterações das medidas FMA, SN.GoGn e PFH, AFH, PFH/AFH, AFP, AFA, 
AFP/AFA, CMS-Franc, CMS-PP e CMI-PM para

o Grupo III 128

TABELA 5.15- Coeficiente de correlação de Pearson para verificar a correlação entre as alterações das medidas FMA, SN.GoGn e PFH, AFH, PFH/AFH, AFP, AFA, AFP/AFA, CMS-Franc, CMS-PP e CMI-PM para o Grupo IV. 128

TABELA 5.16- Coeficiente de correlação de Pearson para verificar a correlação entre as alterações da altura facial anterior e as medidas lineares dentoalveolares CMS-Franc, CMS-PP, CMI-PM, DMS-PTV e DMI-PTV para o Grupo I.

TABELA 5.17- Coeficiente de correlação de Pearson para verific ar a correlação entre as alterações da altura facial anterior e as medidas lineares dentoalveolares CMS-Franc, CMS-PP, CMI-PM, DMS-PTV e DMI-PTV para o Grupo II

TABELA 5.18- Coeficiente de correlação de Pearson para verificar a correlação entre as alterações da altura facial anterior e as medidas lineares dentoalveolares CMS-Franc, CMS-PP, CMI-PM, DMS-PTV e DMI-PTV para o Grupo III 
TABELA 5.19- Coeficiente de correlação de Pearson para verificar a correlação entre as alterações da altura facial anterior e as medidas lineares dentoalveolares CMS-Franc, CMS-PP, CMI-PM, DMS-PTV e DMI-PTV para o Grupo IV 130 


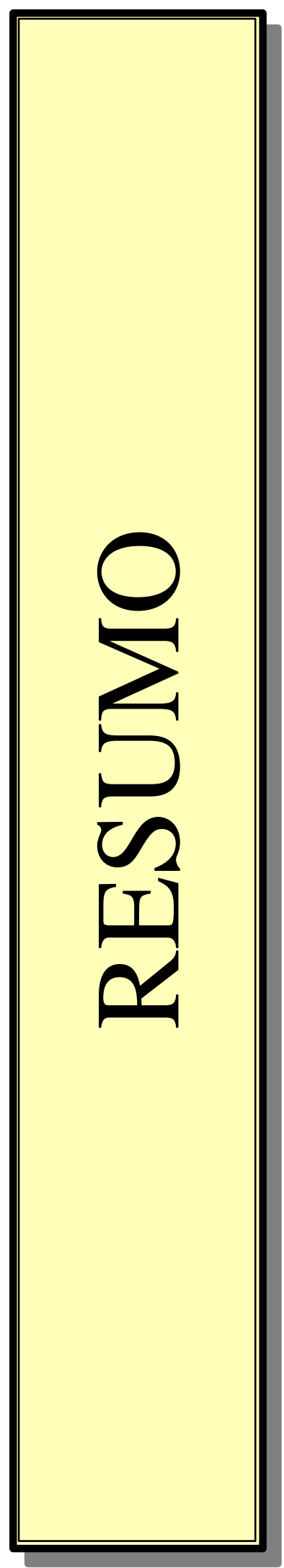

xxvi 


\section{RESUMO}

$\mathbf{E}$

mbora muito estudados, os efeitos da extração dos quatro primeiros pré-molares sobre as alturas faciais ainda causam certa controvérsia. Devido à variação de resultados encontrados na literatura e pelo fato de todos os estudos terem sido realizados em leucodermas, propusemonos a analisar cefalometricamente as alterações das alturas faciais anterior e posterior em pacientes nipo-brasileiros com más oclusões de Classe I e II, $1^{\underline{a}}$ divisão de Angle tratados ortodonticamente.

A amostra consistiu de quatro grupos: Grupo I - 15 jovens com Classe I tratados com extração dos quatro primeiros pré-molares; Grupo II - 15 jovens com Classe I tratados sem extrações; Grupo III - 14 jovens com Classe II, $1^{\underline{a}}$ divisão tratados com extração dos quatro primeiros pré-molares; Grupo IV- 15 jovens com Classe II, $1^{\underline{a}}$ divisão tratados sem extrações. Todos foram tratados com a técnica do Arco de Canto Simplificada por um período médio de 2,49 anos. A idade média inicial foi de 12,14 anos e a final de 14,64 anos.

A análise dos resultados revelou que a extração de pré-molares não diminui a dimensão vertical em pacientes nipo-brasileiros com padrão de crescimento equilibrado, uma vez que as alterações nas alturas faciais anterior e posterior foram similares nos quatro grupos estudados, apresentando aumento de ambas ao final do tratamento ortodôntico. As alterações dos ângulos FMA e SN.GoGn não foram estatisticamente significantes e, quanto ao Índice de Horn e à proporção AFP/AFA, verificou-se aumento nos Grupos 
I e III. Observou-se dimorfismo apenas nas medidas dentoalveolares DMSPTV e DMI-PTV, no Grupo I, e nas medid as CMI-PM, PFH e AFP, no Grupo III, em que o gênero masculino apresentou valores maiores que o feminino. 


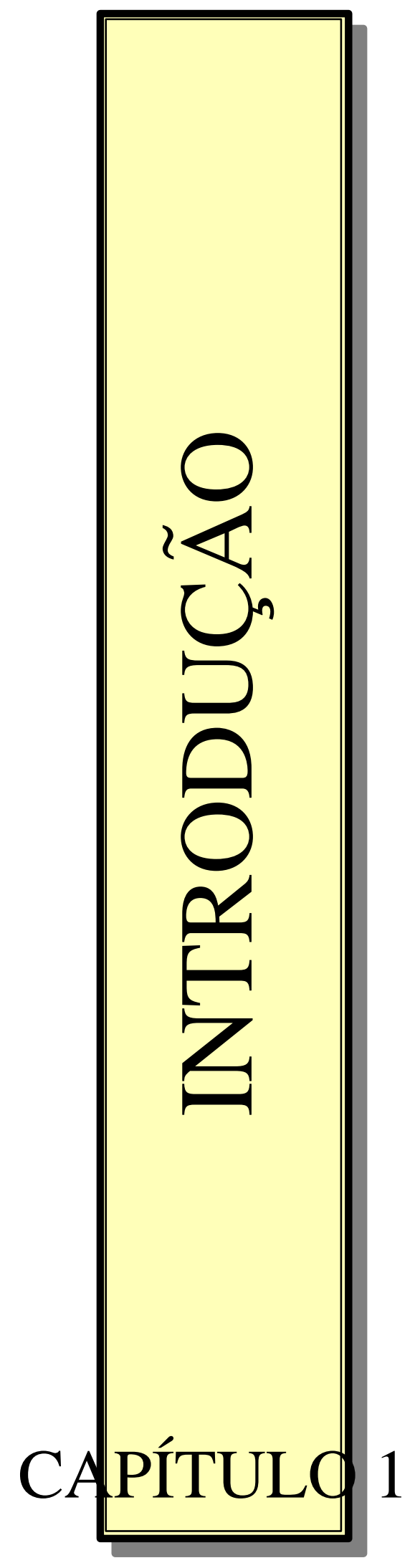




\section{INTRODUÇÃO}

No final do século XIX, o pai da Ortodontia, Dr. Edward Hartley ANGLE $^{5}$, classificou as más oclusões de uma maneira bastante didática e, por esse motivo, foi amplamente divulgada, sendo utilizada até os dias de hoje. Entretanto, sua classificação foi definida apenas no sentido horizontal. Isso, de início, instigou os pesquisadores a se preocuparem principalmente com o equilíbrio ântero-posterior do complexo craniofacial.

Com o aprimoramento dos conhecimentos científicos relacionados à cefalometria e ao processo de crescimento e desenvolvimento craniofacial, observou-se que, para a obtenção da estética facial, é necessário haver equilíbrio e harmonia não somente no sentido horizontal, mas também no transversal e no vertical.

Segundo SASSOUNI; NANDA ${ }^{178}$, em 1964, e LINDER-ARONSON; WOODSIDE $^{119}$ em 2000, muitas más oclusões ântero-posteriores são decorrentes de um desenvolvimento vertical anormal. ORTIAL ${ }^{153}$, em 1995, relatou que o padrão esquelético no sentido vertical constitui um fator que diferencia as más oclusões com um relacionamento dentário idêntico. Logo, se o crescimento normal das alturas faciais for bem compreendido, o ortodontista terá um meio mais efetivo de diagnosticar a má oclusão e tratá-la de modo eficiente e correto.

A altura facial anterior e a altura facial posterior desempenham papéis fundamentais no equilíbrio e harmonia da face humana, pois orientam o sentido da rotação mandibular. Em oclusões normais, a face cresce 
verticalmente mais na parte posterior do que na anterior, ou seja, a altura facial posterior desenvolve-se mais do que a anterior ${ }^{11,63,82,101,127}$. Assim, para que o tratamento ortodôntico seja efetivo e com resultados estáveis, deve ser harmonioso com o processo de crescimento normal, compensando os casos de padrões faciais desfavoráveis. Para o padrão de crescimento vertical, SCHUDY $^{184}$ e outros autores ${ }^{41,51,111,175}$ aconselham compensá-lo, sempre que possível, por meio de tratamento ortodôntico com extrações.

A literatura pertinente demonstra que os casos tratados com sucesso não apresentam diferenças significantes em relação ao processo de crescimento normal, ao passo que os casos tratados sem sucesso apresentam um maior aumento da altura facial ântero-inferior em relação ao aumento da altura facial póstero-inferior, acentuando a convexidade facial, o que é desfavorável para a estética, especialmente em casos de Classe II com ângulo FMA aumentado ${ }^{70,75,76}$. Sendo assim, alguns autores propuseram a utilização de índices de altura facial durante o tratamento ortodôntico para o controle da resposta mandibular ${ }^{91,120,121}$. Além disso, a realização de extrações dentárias é vista de modo favorável no tratamento de pacientes com padrão de crescimento hiperdivergente, pois acredita-se que esta manobra colabora para o controle da dimensão vertical da face ${ }^{39,53,75,76,105}$. Em relação ao padrão de crescimento horizontal, a literatura ortodôntica encontra-se bastante escassa.

Ainda hoje, os efeitos das extrações dos quatro primeiros pré-molares sobre as alturas faciais não se encontram claramente definidos. Há autores que contra-indicam a extração de pré-molares, principalmente nos casos de Classe II com padrão de crescimento equilibrado ou horizontal, pois relatam que a 
mesialização dos molares provoca o fechamento do ângulo do plano mandibular de modo acentuado, diminuindo a dimensão verticall ${ }^{28,160,202,217}$.

Face ao exposto, tornou-se evidente a necessidade de se verificarem quais as alterações provocadas pelo tratamento ortodôntico com e sem extrações dos quatro primeiros pré-molares sobre as alturas faciais nas más oclusões de Classe I e de Classe II, 1' divisão. Além disso, atualmente, a sociedade brasileira é composta por várias etnias, necessitando de estudos que as caracterizem, tanto nas más oclusões como nas oclusões normais. Os brasileiros descendentes de japoneses representam uma parcela considerável da população, particularmente nos estados de São Paulo e Paraná. Entretanto, não foi encontrado, na literatura brasileira, nenhum estudo cefalométrico sobre as alterações suscitadas pelo tratamento ortodôntico em nipobrasileiros. 


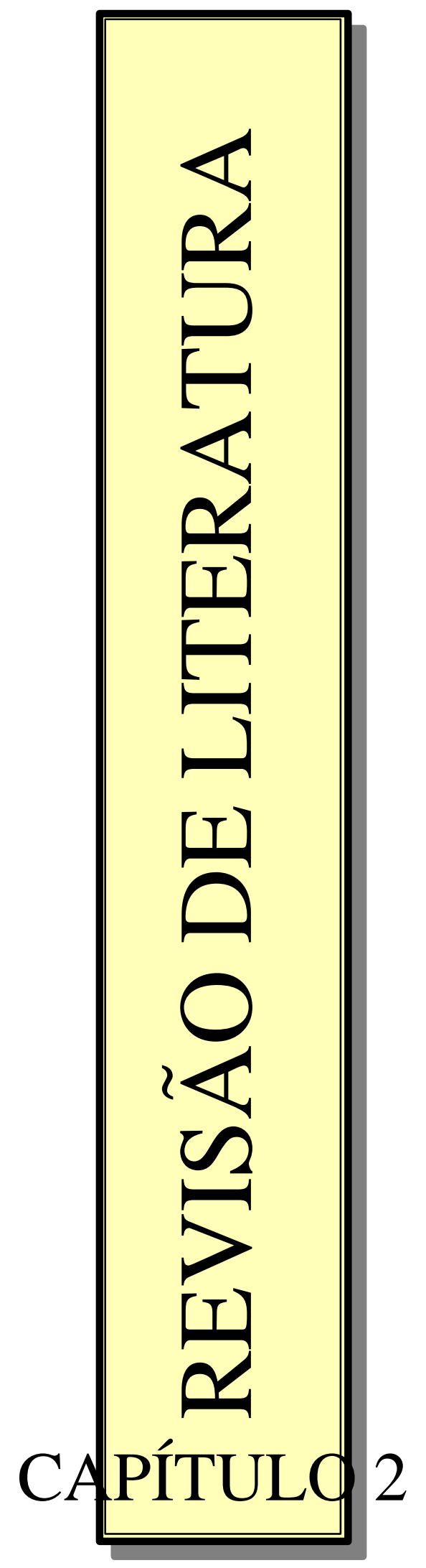




\section{REVISÃO DE LITERATURA}

Para uma maior compreensão e facilidade de leitura, a revisão de literatura foi dividida em cinco tópicos:

2.1- A estética e o estudo das proporções faciais na arte e na ciência

2.2- $\mathrm{O}$ crescimento e desenvolvimento craniofacial no sentido vertical

2.3- As proporções faciais verticais

2.4- O controle vertical no tratamento ortodôntico com e sem extrações

2.5- O estudo cefalométrico em grupos raciais e étnicos

No primeiro deles, "A estética e as proporções faciais na arte e na ciência”, associaram-se os valores estéticos em Ortodontia e as proporções faciais aos estudos e à Filosofia da Arte, pois os conceitos de estética, equilíbrio e harmonia em Odontologia foram extraídos das produções artísticas e das idéias estéticas filosóficas, conforme explanado por LUNA; BLAHA $^{122}$ apud CARDOSO ${ }^{40}$, em 1990. A compreensão de uma arte só é possível a partir da análise da época em que ela se desenvolveu. Logo, essa primeira parte da revisão de literatura descreve resumidamente a estética e o estudo das proporções faciais dentro de todo um contexto histórico. Entretanto, na História da Arte, segundo OUVRARD ${ }^{154}$, em 1964, o que interessa ao cirurgião-dentista, particularmente, são os momentos em que o homem reproduz sua própria imagem.

A revisão da literatura pertinente demonstrou a necessidade de se estudar não somente as alturas faciais, e o processo de crescimento no sentido vertical, mas também a estética e as proporções da face, uma vez que elas se 
encontram intimamente relacionadas às alterações nas alturas faciais. Embora o equilíbrio e a harmonia da face humana não recebam influência apenas desses dois fatores, é de suma importância que o ortodontista possua o conhecimento dos padrões de normalidade, para que assim ele possa reconhecer mais facilmente as anormalidades do complexo craniofacial (ARNETT; BERGMAN ${ }^{8}$, 1993; BASS ${ }^{10}$, 1991; CHRISTIE ${ }^{44}$, 1977; COX; VAN DER LINDEN ${ }^{50}, \quad$ 1971; DOWNS ${ }^{63}, 1948 ; \quad$ LOCKS $^{121}, 1996$; LUSTERMAN $\left.^{123}, 1963\right)$.

TWEED $^{203}$, em 1944, declamou que o conceito de normalidade é indispensável ao ortodontista; sem este, ele não sabe onde iniciar ou terminar seu tratamento. Dessa maneira, ele definiu o "normal" como sendo o equilíbrio e a harmonia de proporções consideradas como as mais agradáveis na face humana.

Para avaliar as deficiências de proporções, as anormalidades de crescimento e para orientar a dentição, MARGOLIS ${ }^{126}$, em 1947, afirmou que se deve estabelecer um conceito de padrão facial normal, que funcione como um guia para o ortodontista.

Desde os seus primórdios, a Ortodontia busca padrões ideais para direcionar o planejamento e o término do tratamento. A grande dificuldade encontrada, segundo CZARNECKI; NANDA; CURRIER ${ }^{54}$, em 1993, é que a estética e a harmonia não são conceitos fixos e os padrões de beleza variam apreciavelmente de pessoa para pessoa, entre as diferentes etnias, além de serem influenciados pelo padrão sócio-econômico-cultural. Assim, pelo fato 
da estética ser um sentimento muito pessoal e subjetivo, a avaliação das proporções faciais é muito mais útil do que a avaliação estética por si só.

ANGLE $^{6}$, em 1907, já afirmava que, para a correção de uma má oclusão, era necessário estudar a Arte, uma vez que o estudo da Ortodontia encontra-se indissoluvelmente associado a ela.

Outro ponto importante a ser discutido neste trabalho é que, com o desenvolvimento das diferentes análises cefalométricas, começaram-se a verificar que o diagnóstico, o resultado final e a estabilidade da correção ortodôntica eram dependentes das limitações impostas pelo tipo facial do paciente, que por sua vez, variava de acordo com o grupo racial ou étnico ao qual pertencia. Daí a importância de analisar cada caso como único, levandose em consideração as diferenças étnico-culturais.

\section{1- A ESTÉTICA E O ESTUDO DAS PROPORÇÕES FACIAIS NA ARTE E NA CIÊNCIA}

As considerações sobre a estética facial compõem parte inseparável e cada vez mais relevante dos conceitos e da prática da Ortodontia, cujos princípios científicos, apesar de bastante solidificados, não deixam de apresentar também seu lado artístico.

A palavra estética, segundo $\mathrm{PECK}^{159}$, em 1997, é derivada do grego "aisthesis", que significa algo perceptivo, especialmente pela sensibilidade, 
envolvendo muita subjetividade. Porém, apesar de filósofos gregos como Sócrates (470-399 a.C.), Platão (428-347 a.C.) e Aristóteles (384-322 a.C.) já estudarem e desenvolverem intrincadas fórmulas para construir representações humanas e divinas da beleza, curiosamente, nunca aplicaram nenhum termo específico para as descreverem. Apenas em meados do século XVIII, o termo "aesthetica" foi empregado pela primeira vez pelo filósofo alemão Alexander Baumgarten em um tratado em latim sobre a beleza da poesia; a partir daí, o termo passou a ser imediata e amplamente aplicado às artes e à natureza.

Desde a Pré-História, há uns 40 mil anos, o homem vem desenvolvendo sua consciência estética e sua sensibilidade. As considerações conscientes de estética foram provavelmente poucas devido à preocupação com as necessidades materiais para a própria sobrevivência, conforme os relatos de PECK\&PECK ${ }^{158}$, em 1970. É interessante observar, no entanto, que existem milhares de exemplos de desenhos, pinturas e esculturas pré-históricas encontradas em cavernas. Essas obras de arte demonstram que os artistas préhistóricos já tinham conhecimento sobre as cores, simetria, harmonia e proporções. As esculturas representavam crianças e mulheres, e destacavam principalmente o corpo e não a face.

O estudo das proporções faciais foi destaque na cultura egípcia. As primeiras evidências que denotam a preocupação com a estética facial surgiram com os artistas egípcios durante as dinastias do Reino Antigo (2.600 - 2.000 a.C.). Uma das características de suas esculturas era a imobilidade das pessoas retratadas. Toda a atenção se concentrava na face, que representava o ideal egípcio de beleza, harmonia e proporção. Segundo GARNOT ${ }^{73}$, em 
1958, nos templos funerários do Antigo Egito havia uma câmara destinada às estátuas, que eram concebidas com finalidade funerária e religiosa. Isso explica a expressão tranqüila e estática dos deuses e faraós retratados, tal qual exigia a nobreza e sua natureza imortal. Estas estátuas serviam, momentânea ou definitivamente, de moradia para os espíritos desencarnados; por isso, as características faciais eram produzidas o mais fielmente possível, já que a face é a parte mais característica e individual do ser humano. Caso contrário, a alma encontraria dificuldade para "entrar" na estátua do morto. Eles utilizavam um sistema quadriculado com o intuito de desenharem as figuras humanas em proporções ideais, principalmente os reis e faraós. Os nobres inferiores eram retratados mais realisticamente. PECK $^{159}$, em 1997, relatou que, em todos os casos, porém, as proporções faciais eram as mesmas para homens e mulheres em todo esse período. Para eles, beleza e divindade eram sinônimos. SMITH ${ }^{189}$, em 1961, estudando os exames radiográficos de remanescentes mumificados de antigos egípcios, na Universidade de Michigan, confirmou a alta incidência de prognatismo bimaxilar daquela população. Essa característica provavelmente vem do fato do vale do Nilo ter sido originariamente ocupado por uma sucessão de povos da África e da Ásia.

Seguindo a evolução histórica da Arte, os gregos, a partir do século V a.C., também se destacaram no estudo da beleza e estética, embora ainda não se preocupassem com o dimorfismo entre os gêneros. A Arte Grega Clássica simboliza o humanismo, a glorificação do homem como a mais importante criatura do universo. Os estudos de BURNS ${ }^{37}$, em 1972, revelaram que tanto a arquitetura quanto a escultura continham os ideais de equilíbrio, harmonia, ordem e moderação. Na Grécia Antiga, por volta do século V a.C., a beleza era considerada um caminho para o bem e para a verdade. Uma estátua grega 
traduzia um ideal ao mesmo tempo artístico, moral e intelectual de perfeição humana. Dois grandes escultores gregos estabeleceram regras estritas para as proporções corporais e as relações anatômicas harmoniosas: Policleto (450420 a.C.) e Fídias (500-432 a.C.). Dessa forma, eles seguiam fielmente uma fórmula de proporção, a "Lei de Polycletus", em que a face compreendia 1/10 da altura do corpo e a cabeça, 1/8, conforme os estudos de BASS ${ }^{10}$, em $1991 \mathrm{e}$ WILLIAMS $^{212}$, em 1953. A face, por sua vez, era dividida em três partes iguais: do queixo ao limite inferior do nariz, deste ponto ao limite superior do nariz e deste até a linha do cabelo. A estética facial da Escultura Grega atraiu sobremaneira os primeiros ortodontistas, como ANGLE ${ }^{6}$, em 1907. Ele considerava Apolo de Belvedere e Afrodite (Vênus de Milo) os protótipos de beleza facial, pois eram perfis bastante retificados. Ainda que ANGLE ${ }^{6}$ admitisse que "beleza, equilíbrio e harmonia" não se limitavam a um só tipo facial, mas sim a vários, conservou o modelo de Apolo como o mais agradável em termos estéticos. Contudo, sua teoria de que a oclusão adequada exigia a presença de todos os dentes impreterivelmente fez com que não alcançasse o padrão ideal em seus pacientes. A expansão das arcadas dentárias para o alinhamento dos dentes resultava, muitas vezes, num perfil facial convexo, biprotruso, exatamente o oposto do perfil de Apolo proposto por ele.

Quando a Grécia foi tomada por Alexandre, deu-se início ao período helenístico, no qual a beleza "idealizada" foi deixada de lado e as artes passaram a retratar mais a realidade. Com a conquista da Grécia pelos romanos, houve um retorno do ideal de beleza grego. 
Muito tempo assim se passou até que, no final do século IV d.C., toda a Europa, por influência religiosa cristã, começou a condenar a beleza física e a exaltar a beleza espiritual. Deu-se início, desse modo, à Idade Média, ou Idade das Trevas. Para PECK; PECK ${ }^{158}$, em 1970, foi nessa época que as contribuições gregas e romanas para a compreensão da beleza foram consideradas pagãs, sendo que um grande número de obras foi destruído por esse motivo.

Somente durante o Renascimento, no século XV d.C., é que a estética voltou a ter destaque na arte ocidental. Foi um período de transição, recebendo influências dos ideais clássicos da beleza greco-romana, mas agora procurando definir a beleza natural e não mais a ideal. Leonardo Da Vinci (1452-1519) foi o primeiro renascentista a desenhar a cabeça, a face e os dentes à procura da harmonia maxilofacial. SOLNICA ${ }^{190}$ apud CARDOSO ${ }^{40}$, em 1974, e BAIRD ${ }^{9}$ apud $\mathrm{JANSON}^{101}$, em 1952, observaram que seus conceitos de estética facial são utilizados até os dias de hoje. Desenhou as más formações e reabsorções dos maxilares, as perdas dentárias e as más oclusões que afetavam a face, chegando à caricatura. Simultaneamente a esses estudos, procurou definir também os possíveis tipos de normalidade facial. Em seus desenhos, Leonardo Da Vinci utilizou as proporções divinas para dar harmonia às faces. A divina proporção ou "secção ideal" originária da teoria de Pitágoras, foi adotada por Platão como uma relação matemática que expressa a harmonia universal e também uma medida ideal para governar a relação dos elementos do corpo humano. Encontra-se relacionada com a série de Fibonacci e é expressa por 1/1,618 ou, simplificando, 5/8. A secção ideal é considerada importante esteticamente e ocorre em muitas formas naturais, como as flores, as conchas e os flocos de neve. É interessante observar que, 
quatro séculos depois, a proporção 1/1,618 levou $\operatorname{RICKETTS~}^{170}$, em 1982, a propor uma divina proporção para a análise facial com fins ortodônticos e cirúrgicos.

Atualmente, com a grande propagação dos meios de comunicação, os valores estéticos encontram-se acentuados. Um número cada vez maior de mulheres e de homens procura por cirurgiões-plásticos, cirurgiões bucomaxilofaciais e ortodontistas.

Com o aprimoramento dos conhecimentos científicos relacionados à cefalometria e ao processo de crescimento e desenvolvimento craniofacial, juntamente com os valores estéticos, um enfoque cada vez mais acentuado está sendo dado às discrepâncias verticais da face, principalmente às alturas faciais inferiores anterior e posterior, pois encontram-se intimamente relacionadas à estética facial e ao sucesso e estabilidade dos casos tratados ortodonticamente. A endência atual das análises cefalométricas e da análise facial é a preocupação com as proporções verticais da face, pois são elas que orientam o sentido de rotação mandibular, fundamental para a estética facial.

Simultaneamente à evolução da Ortodontia, um fato interessante relatado por PECK \& $\mathrm{PECK}^{158}$ foi que há 20 anos, a extração dos pré-molares compunha cerca de 60 a $80 \%$ dos casos e atualmente este número caiu para aproximadamente $20 \%$. Isso sugere que o ortodontista de hoje está elaborando um plano de tratamento mais individualizado, e que, apesar de haver necessidade de mais estudos, já demonstra certa preocupação com as discrepâncias verticais. 
Assim, para a continuidade e compreensão desta linha de pensamento, serão descritos, a seguir, o processo de crescimento e desenvolvimento craniofacial no sentido vertical e os principais trabalhos correlatos.

\section{2- O CRESCIMENTO E DESENVOLVIMENTO CRANIOFACIAL NO SENTIDO VERTICAL}

Os primeiros trabalhos sobre o crescimento e desenvolvimento craniofacial iniciaram-se no século XVIII e se definiam como estudos qualitativos, ou seja, preocupavam-se com o processo de crescimento em si, em suas características histológicas sem, no entanto, quantificá-lo (BELCHIER $^{13}, \quad 1736$; DUHAMEL ${ }^{66}, \quad 1739 ;$ HUNPHREY $^{93}, \quad 1864$; HUNTER $^{94}, 1771$ apud BRODIE $\left.{ }^{33}, 1941\right)$.

Para o estudo do crescimento humano quantitativo, o primeiro método utilizado pela antropologia foi a craniometria, cuja maior vantagem é a possibilidade de se obter medidas precisas diretamente em crânios secos. Porém, como relatado por PROFFIT ${ }^{164}$, em 1986, a desvantagem deste processo é que ele fornece apenas dados transversais do crescimento pela comparação de crânios secos de diferentes idades. Outra desvantagem, segundo TODD ${ }^{201}$, em 1981, é que esses crânios secos podem ter sido de crianças mortas por algumas doenças crônicas que poderiam ter alterado o curso normal do crescimento craniofacial. 
Apesar das limitações impostas à craniometria, alguns autores realizaram estudos que são consagrados e aplicáveis à Ortodontia até os dias atuais. HELLMAN ${ }^{82,84}$, em 1927, realizou dois importantes estudos em crânios secos, concluindo que o crescimento da face ocorre por meio de cinco processos: crescimento em largura, altura e profundidade; ajuste da posição facial e modificação dos ângulos faciais. $\mathrm{O}$ autor observou ainda que estes incrementos não ocorrem com a mesma intensidade, velocidade ou época levando, dessa forma, a uma alteração nas proporções faciais e à diminuição dos ângulos facial, alveolar, goníaco e mentoniano.

Em 1930, KROGMAN ${ }^{113}$ reiterou os achados de HELLMAN ${ }^{82}$, quando relatou que o crescimento não ocorre uniformemente, mas sim com alteração nas proporções faciais.

Para o acompanhamento progressivo do crescimento em uma única criança, houve necessidade de uma padronização das tomadas radiográficas para que as mesmas medições, realizadas em épocas diferentes, pudessem ser comparadas corretamente, obtendo-se dados longitudinais do crescimento. Isso somente se tornou possível com a introdução do cefalostato, por BROADBENT $^{30}$, nos Estados Unidos, e HOFRATH ${ }^{90}$, na Alemanha, em 1931. Essa nova técnica foi denominada de telerradiografia cefalométrica, que a partir de então se tornou um instrumento de comparação in vivo bastante confiável, além de ser imprescindível ao estudo do crescimento e desenvolvimento craniofacial.

Continuando seus estudos, mas agora com o auxílio da cefalometria, $\operatorname{HELLMAN}^{83,85}$, em 1932 e 1935, reafirmou que a face da criança se 
transforma na do adulto por aumento em tamanho, por alterações nas proporções e pela mudança de sua posição em relação à base do crânio. Assim, o incremento vertical é maior na região posterior do que na anterior; nos sentidos transversal e ântero-posterior, o maior aumento ocorre na região inferior da face, sendo que ele também observou diferenças entre os gêneros quanto à época, velocidade, quantidade e intensidade de crescimento.

Os primeiros pesquisadores que se interessaram pelo estudo cefalométrico longitudinal do crescimento e desenvolvimento craniofacial, no início do século XX, advogavam que o padrão de crescimento se estabelecia precocemente e não se alterava com o evoluir da idade. BROADBENT ${ }^{31}$, em 1937, pontificou que o padrão de crescimento facial dirige-se para frente e para baixo, sendo estabelecido quando a dentadura decídua se completa e permanecendo constante até o final do crescimento.

Também em concordância com BROADBENT ${ }^{31}$, BRODIE $^{33}$, em 1941, explicou que o padrão de crescimento expressa a manutenção das proporções das estruturas faciais entre si, apresentando uma mesma proporção relativa em qualquer idade, tanto no crescimento normal como nos desvios de normalidade. Para BRODIE ${ }^{33}$, o ângulo SN.Gn era um dos mais estáveis durante o processo de crescimento.

A partir de então, o que se observa na literatura pertinente é uma verdadeira concentração de esforços em se saber se o padrão de crescimento e as proporções faciais eram constantes ou se alteravam com a idade e também de se compreender como esse complexo processo ocorria. 
Estudando 326 crânios humanos originários de várias partes do mundo, HERZBERG \& HOLIC $^{89}$, em 1943, objetivaram confirmar os resultados de $\mathrm{BRODIE}^{33}$ relativos à constância do padrão de crescimento. Além disso, verificaram o efeito do desgaste dentário por atrito sobre a altura facial anterior $(\mathrm{N}-\mathrm{Gn})$, observando também em quais variáveis havia diferenças raciais. Ao dividir a altura facial anterior em superior (N-ENA) e inferior (ENA-Gn), concluíram que havia uma constância de proporcionalidade independentemente da idade ou grupo racial, ou seja, a altura facial ânterosuperior representava $43,51 \%$ da altura facial anterior total e a altura facial ântero-inferior, $56,49 \%$. Observaram também que o desgaste dos dentes pelo atrito não alterou as proporções faciais nem a distância N-Gn.

Em 1944, WYLIE ${ }^{214}$ demonstrou que as alturas nasal e dentária encontram-se entre as dimensões craniofaciais mais estáveis, concordando com BRODIE $^{33}$ de que a proporcionalidade das partes faciais não se altera com o crescimento.

Dois anos mais tarde, em outro importante estudo cefalométrico, BRODIE $^{34}$ afirmou que a altura nasal e a altura facial ântero-inferior apresentam a mesma porcentagem relativa com o decorrer da idade, sendo que esta regra se aplica às diversas medidas faciais. Entretanto esclareceu que quando se relaciona uma medida craniana a uma facial, obtém-se o gráfico de uma curva, pois a velocidade de crescimento do crânio diminui mais precocemente do que a velocidade de crescimento facial. Posteriormente, TIRK $^{200}$, em 1948, também concordaria com os resultados de BRODIE ${ }^{34}$. 
Em busca de se estabelecer correlações entre a dimensão vertical do ramo mandibular, a distância vertical entre as arcadas dentárias e o grau de sobremordida, WYLIE ${ }^{215}$, em 1946, estudou uma amostra constituída de 90 telerradiografias laterais pré-tratamento, pertencentes a 61 jovens do gênero feminino e 29 do masculino, na fase de dentadura permanente. Estes pacientes foram divididos de acordo com o gênero e de acordo com o grau de sobremordida: suave (1,5 a $2 \mathrm{~mm}$ ), média e acentuada (borda do incisivo inferior além da altura do cíngulo do incisivo superior). O principal motivo que o incentivou a realizar esse trabalho foi a discordância com a teoria proposta por DIAMOND ${ }^{61}$, em 1943, que advogava que a causa da sobremordida acentuada era a falta de desenvolvimento suficiente do ramo mandibular, uma vez que este causaria um espaço intermaxilar diminuído. Se isso de fato ocorresse, então WYLIE ${ }^{215}$, ao comparar os casos de sobremordida suave, média e acentuada, deveria observar que, quanto mais acentuada a sobremordida, menor seria a altura do ramo da mandíbula. Porém, verificou-se diferença estatisticamente significante apenas na altura facial anterior total e na ântero-inferior, principalmente entre os grupos de sobremordida suave e acentuada. Não houve dimorfismo entre os gêneros. Concluiu também que, apesar do crescimento do ramo mandibular apresentar importância nas linhas faciais harmoniosas, não mantém correlação com o grau de desenvolvimento do espaço intermaxilar.

Contrariamente aos estudos de BRODIE ${ }^{33,34}$, TIRK $^{200}$, WYLIE $^{215}$ e $\operatorname{outros}^{33,89}$, vários autores observaram alterações nas proporções faciais, principalmente na puberdade. Foi assim que, em 1947, BJÖRK ${ }^{25}$ comparou cefalometricamente o prognatismo facial de 322 jovens suecos, aos 12 anos de idade, com o de 281 adultos, todos do gênero masculino. Como nenhuma 
alteração na forma da base craniana foi observada, atribuiu-se ao aumento do prognatismo a alteração da relação entre a base craniana e o comprimento das bases apicais. Apesar do aumento do comprimento das bases apicais ter sido praticamente proporcional, houve um maior aumento do prognatismo mandibular em relação ao maxilar. Segundo o autor, isso ocorreu devido a um deslocamento mais acentuado da mandíbula para frente, que foi associado, por sua vez, ao aumento em altura do ramo, uma vez que, durante o mesmo período, cresceu o dobro em relação ao aumento da altura facial anterior.

Apesar de BRODIE ${ }^{35}$, em 1950, afirmar não ter encontrado nenhuma evidência que pudesse alterar suas conclusões sobre o processo de crescimento facial obtidas em $1941^{33}$, JOHNSON ${ }^{103}$, também em 1950, verificou alterações nas proporções faciais durante o crescimento. Em seu trabalho, visou estudar algumas medidas cefalométricas verticais em diferentes padrões faciais, avaliando um grupo de 150 jovens, com oclusão normal e morfologia facial aceitável, de acordo com os valores do ângulo FMA. Observou que, à medida que o FMA aumentava, havia uma leve tendência ao aumento da altura facial ântero-superior. Já a altura facial ânteroinferior apresentou um aumento consistente, sendo determinado principalmente pelo crescimento vertical dos processos alveolares superior e inferior. Desse modo, a AFAI apresenta importante papel no estabelecimento da altura facial anterior total e no valor do ângulo FMA, conforme BRASH ${ }^{29}$, em 1946, já havia pontificado.

Paralelamente a esses trabalhos, observou-se também uma crescente preocupação com o dimorfismo entre os gêneros durante o crescimento craniofacial. Assim, PETRAITIS ${ }^{162}$, em 1951, comparando os padrões faciais 
de jovens dos gêneros masculino e feminino, de 12 anos de idade com os de adultos, verificou que os padrões faciais dos meninos foram significantemente diferentes dos adultos, ao passo que os padrões faciais do gênero feminino não, exceto pelo tamanho.

Ainda em 1951, duas importantes pesquisas realizadas por BJÖRK ${ }^{26} \mathrm{e}$ $\mathrm{BAUM}^{11}$, nas quais compararam as estruturas faciais de crianças e adultos, destacaram-se ao confrontarem os resultados de BRODIE $^{34}$ e BROADBENT $^{31}$ sobre a constância do padrão de crescimento. Segundo eles, a estrutura facial encontra-se sujeita a consideráveis alterações no seu padrão, durante o processo de crescimento, principalmente durante a adolescência.

Num estudo longitudinal em 34 jovens do gênero masculino, dos 4 anos e 5 meses aos 17 anos e 1 mês, LANDE ${ }^{116}$, em 1952, demonstrou alterações no perfil ósseo, observando uma diminuição da convexidade facial, uma diminuição do ângulo SN.GoGn e um crescimento não proporcional do osso alveolar em relação à sua base óssea no sentido horizontal.

Estudando-se, comparativamente, crianças dos 7 aos 9 anos, de ambos os gêneros e crianças dos 11 aos 13 anos, também com oclusão normal e de ambos os gêneros, BAIRD ${ }^{9}$, em 1952, concluiu que os meninos apresentaram constância no padrão de crescimento, aumentando apenas em tamanho. O gênero feminino, entretanto, apresentou alterações no padrão facial, com uma diminuição da convexidade do perfil e aumento do ângulo facial com a idade, além de uma maior dimensão das estruturas. Em ambos os grupos, a mandíbula cresceu mais do que a maxila. 
Com o fim precípuo de se verificar em quais idades ocorria o maior incremento no sentido vertical, MCNAIR ${ }^{133}$, em 1953, estudou 107 casos com oclusão normal, sendo 50 meninos e 57 meninas, entre os 7 e os 14 anos. Verificou que o maior crescimento vertical ocorreu entre as idades de 12 e 13 anos no gênero masculino e entre os 11 e 12 anos no gênero feminino.

Objetivando averiguar se as proporções faciais nos planos horizontal e vertical permaneciam constantes com a idade, WILLIAMS ${ }^{212}$, em 1953, realizou um estudo cefalométrico longitudinal em 30 jovens (24 do gênero masculino e 6 do feminino), utilizando telerradiografias tomadas nas fases pré (8,13 anos em média) e pós-pubescente (15,16 anos em média). Todos apresentavam oclusão normal e nunca tinham sido submetidos ao tratamento ortodôntico. Concluiu que as proporções verticais são mais variáveis que as horizontais, advertindo quanto à necessidade de estudos complementares neste contexto.

Estudando as alterações das alturas faciais e sua relação com a profundidade facial, $\mathrm{COBEN}^{47}$, em 1955, analisou 47 jovens leucodermas com idades entre os 8 e 16 anos, com oclusão normal, sendo 25 do gênero masculino e 22 do feminino. Observou que o gênero masculino apresentou um maior aumento na altura do que na profundidade facial, com mais crescimento na porção anterior do que na posterior. Em geral, os meninos também apresentaram maiores mudanças nas proporções faciais do que no gênero feminino, além de apresentarem um acentuado aumento da dimensão vertical, tornando a face relativamente mais alongada que a feminina. Resultados bastante semelhantes foram obtidos por SHULTZ ${ }^{188}$ no mesmo ano. 
Em 1956, DOWNS ${ }^{64}$ comparou transversalmente os valores cefalométricos de sua análise, obtidos de amostras de jovens com oclusão normal, aos 3, 9 anos e seis meses e 12 anos e 8 meses, verificando que a mandíbula se movimenta para frente em uma velocidade maior que a maxila, aumentando o ângulo facial e diminuindo o ângulo de convexidade. Além disso, concluiu que o crescimento vertical é maior na região do ramo do que na região anterior, levando a uma diminuição do ângulo do plano mandibular. Os jovens do gênero masculino crescem e se desenvolvem continuamente até os 20 anos de idade, enquanto as meninas experimentam mínimas alterações em tamanho e proporção após os 14-15 anos de idade.

Em relação ao crescimento facial no sentido vertical, SCOTT $^{185}$, em 1958, verificou a influência de alguns fatores determinantes, tais como o crescimento da cartilagem do septo nasal simultaneamente ao crescimento do palato para baixo, por aposição e reabsorção, resultando num aumento da cavidade nasal em altura; o componente vertical de crescimento da cartilagem do côndilo mandibular, demonstrado pelo aumento da altura do ramo da mandíbula; e o crescimento do osso alveolar nos maxilares. A extensão do crescimento vertical do processo alveolar superior é indicada pelo aumento da distância entre o plano palatino e o plano oclusal.

Ainda em 1958, estudando a relação dos componentes nasal e subnasal da altura facial em 55 crianças dos 4 aos 12 anos, nunca submetidas a tratamento ortodôntico, MEREDITH; KNOTT; HIXON ${ }^{137}$ analisaram a proporção entre a altura nasal (N-ENA) e a altura subnasal (ENA-Me). Concluíram que o componente nasal da altura facial aumenta em relação ao 
componente subnasal de acordo com a idade, ou seja, aos 4 anos a proporção N-ENA em relação à ENA-Me é de 71,7\% e aos 12 anos, passa para 79,2\%. Também não houve dimorfismo entre os gêneros.

Paralelamente aos inúmeros trabalhos científicos sobre crescimento, MOORE ${ }^{143}$, em 1959, questionou o conceito de "constância do padrão de crescimento facial", preconizado por BROADBENT ${ }^{31}, \mathrm{BRODIE}^{33}$, ao acompanhar longitudinalmente quatro casos com oclusão normal, afirmando que a variação é a regra e não a constância. Concluiu que o tratamento ortodôntico pode influenciar favorável ou desfavoravelmente o padrão de crescimento facial.

Nos estágios finais do crescimento, durante a puberdade, a direção de crescimento mandibular freqüentemente se converte de vertical para horizontal, segundo GRABER ${ }^{79}$, em 1962. Nos meninos, essa alteração na direção de crescimento ocorre mais freqüentemente dos 14 aos 17 anos, geralmente coincidindo com a época após a remoção do aparelho ortodôntico.

Os resultados de um importante estudo longitudinal realizado por $\mathrm{COBEN}^{48}$, em 1961, em 47 jovens dos 8 aos 16 anos de idade, levaram-no a verificar que a sutura frontoetmoidal cessa aproximadamente aos 7 anos de idade. Após este período, qualquer aumento na dimensão entre $\mathrm{S}$ e $\mathrm{N}$ seria devido a um desenvolvimento aposicional no osso frontal. $\mathrm{O}$ crescimento dos ossos da face superior é predominantemente sutural durante a infância. Como a sutura pterigopalatina participa do mesmo complexo que a sutura esfenoetmoidal, ela também cessa o seu crescimento aos 7 anos de idade. Portanto, o desenvolvimento ântero-posterior da face média, após essa idade, 
deve-se à aposição óssea. Logo, o crescimento facial parece apresentar duas fases, a primeira sutural, até os 7 anos de idade, e a segunda, ocasionada principalmente pela aposição e reabsorção. $\mathrm{O}$ crescimento na sincondrose esfenoccipital continua durante a puberdade, aumentando a base craniana posterior, sendo que no gênero masculino esse incremento da base craniana ocorre mais verticalmente. $\mathrm{O}$ crescimento da sincondrose esfenoccipital desloca a face superior e os dentes para cima e para frente; do mesmo modo, o crescimento do côndilo e do ramo desloca o corpo mandibular e os dentes inferiores para baixo e para frente. Entre esses dois vetores, cria-se o espaço para o desenvolvimento vertical da face.

Com o objetivo de se compreender melhor o processo de crescimento e desenvolvimento craniofacial nos padrões faciais extremos, SASSOUNI \& NANDA $^{178}$, em 1964, diferenciaram os pacientes que apresentam mordida aberta esquelética da sobremordida profunda, relatando que a altura dentoalveolar superior é maior no primeiro caso. A altura facial ânteroinferior também é maior e a altura facial póstero-inferior menor. Além disso, um ramo mandibular encurtado, uma posição mais superior do côndilo e uma distância côndilo-molar maior encontram-se relacionados com o desenvolvimento da mordida aberta anterior. Desse modo, os autores concluíram que muitas discrepâncias ântero-posteriores são apenas os efeitos das discrepâncias verticais e o tratamento ortodôntico deve estabelecer o controle da dimensão vertical para se alcançar a correção ântero-posterior e a estabilidade do caso.

Também estudando o diagnóstico e o tratamento das mordidas abertas anteriores, SUBTELNY \& SAKUDA ${ }^{194}$ advogaram que os fatores etiológicos 
envolvidos são a deficiência de crescimento vertical posterior, a função muscular alterada e a presença de hábitos bucais deletérios.

Uma citação do estudo realizado por Behm, na Universidade de Northwestern, foi relatada por SCHUDY ${ }^{184}$, também em 1964, em que ele estudou 60 pacientes com má oclusão de Classe II, $1^{\text {a }}$ divisão, comparando a altura facial anterior e a posterior. Sua conclusão foi que a distância do násio ao mento varia muito menos que a distância da sela ao gônio, ou seja, pontificou que "a porção mais variável do complexo craniofacial é o segmento posterior, que é confirmado pela variabilidade apresentada pelo ângulo formado pelos planos oclusal e mandibular".

Com o intuito de documentar as mudanças de crescimento que causam rotação na mandíbula e suas implicações no tratamento ortodôntico, SCHUDY $^{183}$, em 1965, estudou uma amostra composta por 307 pacientes tratados, com idades entre 11 e 14 anos e divididos de acordo com o tipo facial, comparando-os com um grupo controle formado por 62 jovens, sendo que 29 apresentavam faixa etária de 11 a 14 anos e os outros 33, uma faixa etária de 8 a 11 anos. Concluiu que as variações no crescimento dos côndilos e na área molar são responsáveis pela rotação do corpo da mandíbula. Desse modo, a rotação mandibular no sentido horário é resultante de um crescimento vertical maior na área molar do que da região do côndilo da mandíbula. Em casos mais extremos, essa condição pode causar mordida aberta. A rotação no sentido anti-horário, entretanto, é o resultado de um crescimento condilar maior do que o crescimento vertical na área molar, sendo que em casos extremos pode haver a sobremordida acentuada. Sua principal conclusão, entretanto, foi que, ao contrário do que muitos acreditam, não é o crescimento 
mandibular o principal determinante da morfologia facial e sim o crescimento vertical da maxila. Assim, em casos de padrão vertical, recomendou o controle da extrusão dos molares superiores, evitando-se o uso de elásticos de Classe II e de ancoragem extrabucal cervical.

As direções do crescimento facial da infância até a idade adulta foram relatadas por BERGENSEN ${ }^{14}$, em 1966, comentando que as alterações na oclusão, particularmente as produzidas pela erupção e esfoliação dentárias, podem produzir alterações verticais na posição da mandíbula, resultando posteriormente em alterações na direção do crescimento.

Outro importante autor que declarou que o padrão de crescimento não é constante, podendo ser alterado pelo crescimento e pelo tratamento ortodôntico foi CREEKMORE ${ }^{51}$, em 1967. Dessa maneira, aconselhou que o crescimento vertical deve ser estimulado ou inibido de acordo com as necessidades de cada paciente. Para isso, torna-se fundamental o conhecimento do processo normal de crescimento e desenvolvimento craniofacial, pois somente assim é possível o reconhecimento das anormalidades e seu correto diagnóstico e tratamento.

O crescimento vertical da maxila, principalmente o crescimento alveolar póstero-superior, constitui a causa primária do aumento da altura facial anterior, segundo SCHUDY ${ }^{183}$, em 1968. O crescimento vertical dos primeiros molares superiores excede o crescimento vertical dos incisivos na proporção de 2:1, o que faz com que este seja um importante fator na redução da sobremordida e no estabelecimento da altura facial anterior. 
O terço superior facial cresce de acordo com a curva de crescimento neural, cessando seu crescimento aproximadamente aos 7 anos. Este crescimento foi estudado por KROGMAN ${ }^{115}$, em 1968, em que verificou também que os dois terços inferiores da face seguem a curva de crescimento geral e continuam durante a adolescência. Há uma tendência bem definida de que o surto de crescimento circumpubertário ocorra mais tarde para a face em relação à altura corporal, continuando-se por aproximadamente mais 1 ano.

Devido à grande divergência de opiniões quanto aos fatores que influenciam a mordida aberta esquelética e a sobremordida, RICHARDSON $^{168}$, em 1969, estudou cefalometricamente 110 jovens com mordida aberta e 110 com sobremordida profunda. Concordando com a maioria dos autores de sua revisão, observou que a AFAI é significantemente maior nos casos de mordida aberta. Sugeriu que a sobremordida profunda foi resultante do relacionamento entre o comprimento do corpo da mandíbula, da altura do ramo ascendente e do ângulo por eles formado. Não houve correlação entre a AFAI e as demais dimensões estudadas nos casos de sobremordida profunda, entretanto a base anterior do crânio apresentou-se significantemente maior do que nos casos de mordida aberta.

No mesmo ano, baseando-se nos diferentes padrões de crescimento, SASSOUNI ${ }^{176}$ propôs uma classificação para as más oclusões esqueléticas. Segundo o autor, há dois tipos de desproporções verticais (mordida aberta e sobremordida profunda esqueléticas) e dois tipos de desproporções ânteroposteriores (Classe II e Classe III esqueléticas). Em relação às más oclusões verticais, a classificação foi realizada de acordo com as proporções entre a altura facial posterior (AFP) e a anterior (AFA). Assim, ele definiu a 
sobremordida profunda esquelética como aquela em que a AFP (sela-gônio) é aproximadamente igual à AFA (supraorbitário-mento) e a AFAI (ENAmento) é menor que a AFAS (Sor-ENA). O ramo é longo, tendendo a se igualar em tamanho ao corpo mandibular. Para a mordida aberta esquelética, a AFP tende a ser metade da dimensão da AFA; a AFAI excede a AFAS, enquanto que o contrário ocorre na porção posterior, ou seja, a AFPI é menor que a AFPS.

Estudando 52 crianças, 26 do gênero masculino e 26 do feminino, dos 3 aos 8 anos, com oclusão normal, $\mathrm{CANNON}^{38}$, em 1970, objetivou encontrar parâmetros para a predição do padrão facial. Observou que enquanto as médias da altura facial ântero-inferior foram maiores nos meninos, a altura facial ântero-superior foi maior nas meninas. Concluiu que é possível predizer o tamanho aproximado de muitos componentes craniofaciais. Assim, se uma criança aos 3 anos de idade apresentava a altura facial anterior maior que a média, esta também o será aos 8 anos de idade.

SUBTELNY ${ }^{195}$, em 1970, observou que durante o período de crescimento, a maxila se torna menos protrusiva em relação ao perfil esquelético e o mento mais protrusivo. Esses resultados demonstram que não existe uma proporcionalidade constante no crescimento facial. NANDA \& TANEJA $^{150}$, em 1972, também observaram que o padrão dentário apresentava-se mais protruído e o perfil facial mais convexo na fase de dentadura mista em relação à dentadura permanente.

Com a finalidade de examinar a relação entre as medidas verticais da face e a rotação mandibular, ISAACSON et al. ${ }^{96}$, em 1971, mediu a altura 
facial anterior total, a altura facial ântero-superior, a altura facial ânteroinferior e a altura do ramo nos 3 tipos de padrão de crescimento: vertical, horizontal e equilibrado. Concluiu que nas faces mais alongadas, a altura facial anterior total apresenta-se apreciavelmente aumentada, sendo que a maior parte desse aumento ocorre na altura facial ântero-inferior. A altura facial ântero-superior permanece praticamente constante $(53 \mathrm{~mm})$. Já a altura do ramo mandibular é inversamente proporcional ao ângulo formado por SN e o plano mandibular mais alto (padrão dolicofacial).

Com relação ao estudo da mordida aberta anterior, NAHOUM ${ }^{147}$ foi um dos autores que mais se destacou. Em seu trabalho de 1971, comparou um grupo composto por 52 pacientes com mordida aberta e 82 indivíduos com Classe I. Concluiu que a proporção entre a altura facial ântero-superior e a altura facial ântero-inferior apresentou-se menor na mordida aberta anterior, sendo constante com a idade. A altura facial ântero-superior foi menor, mas a altura facial ântero-inferior foi suficientemente maior para fazer com que a altura facial anterior total na mordida aberta anterior fosse suavemente maior do que na oclusão normal. O ângulo SN.PM e PP.PM foram maiores, mas SN.PP foi menor na mordida aberta, demonstrando assim que a rotação antihorária do plano palatino é um dos responsáveis pela diminuição da altura facial ântero-superior e pelo aumento da altura facial ântero-inferior na mordida aberta anterior, havendo também dimorfismo entre os gêneros.

No ano seguinte, NAHOUM ${ }^{148}$ relatou que a proporção AFAS/AFAI em jovens com oclusão normal e face equilibrada é de 0,810 . Para a mordida aberta anterior, é de 0,686 e para a sobremordida profunda, de 0,900. Sugeriram que estes valores podem servir de guia para a predição dos 
resultados. Assim, em casos de AFAS/AFAI abaixo de 0,650, a indicação ideal é a abordagem cirúrgico-ortodôntica.

O termo "síndrome da face longa" foi introduzido por SCHENDEL et al. ${ }^{180}$, em 1976, para representar um quadro clínico que até então apresentava várias denominações e muitas confusões. Por exemplo, acreditava-se que toda face longa estava associada à mordida aberta anterior. No entanto, existem duas variáveis na face longa: a presença da mordida aberta e a sua ausência. Nos casos com mordida aberta associada, há um ramo mandibular de tamanho normal, enquanto que nos casos sem mordida aberta, este se apresenta aumentado em relação ao normal. Como características comuns, os dois subgrupos apresentam a AFAI aumentada, devido ao desenvolvimento acentuado da maxila no sentido vertical; além disso, há um ângulo do plano mandibular aumentado, um comprimento normal do lábio superior com excesso de exposição dos dentes ântero-superiores e um sorriso gengivoso.

Outros autores que se preocuparam em caracterizar os dois tipos de padrão de crescimento facial vertical: associado ou não à mordida aberta anterior foram FISH; WOLFORD; EPKER. ${ }^{68}$, em 1978. Observaram que a maior diferença entre os grupos encontrou-se na altura facial posterior, ou seja, em casos com mordida aberta anterior, a altura facial posterior foi menor que no grupo que não apresentava mordida aberta associada.

Ao estudarem as proporções cefalométricas de pacientes antes e após o tratamento ortodôntico, SPYROPOULOS \& ASKARIEH ${ }^{191}$ relataram a possibilidade de se encontrar uma das seguintes situações quanto às dimensões faciais verticais: um aumento harmonioso tanto da AFA quanto da 
AFP, com os planos palatino, oclusal e mandibular, numa direção paralela. Isso permite uma constância das proporções entre as alturas faciais anterior e posterior e entre a AFP/AFAI. Esse tipo de mudança foi denominada de “ Mudança tipo A"; um aumento da AFA sem um aumento proporcional da AFP, que pode ser resultante de: um aumento da distância entre a ENA e o plano oclusal; um aumento da distância entre o plano oclusal e o plano mandibular e uma combinação dos fatores citados. Conseqüentemente, poderá haver uma alteração na razão entre as alturas faciais superior e inferior, bem como na razão entre a AFP e a AFAI. É a "Mudança tipo B"; um aumento da AFP sem um aumento proporcional da AFA, rotando a mandíbula no sentido anti-horário e alterando a proporção entre a AFA e a AFP. É a "Mudança do tipo C" e muito raramente, uma ausência de mudança tanto relativa quanto absoluta ("Mudança do tipo D").

Avaliando o crescimento facial antes, durante e após o tratamento ortodôntico, quanto à constância ou não do padrão facial, $\mathrm{CROSS}^{52}$ afirmou, em 1977, que a variação individual é comum; as faces variam em tamanho e forma, ao passo que o crescimento varia em direção e velocidade.

Neste mesmo ano, um célebre estudo experimental foi realizado por MCNAMARA JÚNIOR ${ }^{134}$ com o intuito de se verificar as alterações e os efeitos sobre o processo de crescimento facial promovidos em 5 macacos Rhesus jovens nos quais foram instalados splints cimentados no arco superior, com aberturas de 2, 3, 5, 10 e $15 \mathrm{~mm}$. As modificações foram monitoradas por meio de telerradiografias e implantes metálicos. Os resultados indicaram que parte do aumento da dimensão vertical ocorreu por adaptação e redirecionamento do crescimento, principalmente na maxila, que teve seu 
controle vertical, desenvolvendo-se mais no sentido ântero-posterior. Este estudo demonstrou que o complexo maxilar é uma estrutura plástica, que responde às alterações na abertura da mordida. A importância clínica desse estudo é que o ortodontista pode, por meio de um plano de tratamento correto, aproveitar-se desse conhecimento e redirecionar favoravelmente o crescimento.

Em uma amostra composta por 82 caucasianos (43 do gênero feminino e 39 do masculino), CHRISTIE ${ }^{44}$, também em 1977, realizou um estudo sobre o padrão cefalométrico dos adultos com oclusão normal. Observou que há uma nítida tendência que faz com que o padrão braquifacial apresente mais oclusão normal do que o dolicofacial. Segundo seus resultados, a distância do primeiro molar superior à linha PTV é maior nos primeiros, demonstrando que os arcos dentários destes apresentam mais espaços disponíveis para os dentes. Além disso, a altura facial posterior é aproximadamente 8 milímetros maior e a distância do primeiro molar superior à linha PTV é 4 milímetros maior no gênero masculino. $\mathrm{O}$ autor também aconselha que o diagnóstico sempre leve em conta a discrepância vertical, que muitas vezes dita o plano de tratamento.

Com o intuito de estudar as proporções faciais verticais, DERMAUT \& O’REILLY $^{59}$, em 1978, estudaram uma amostra de 24 meninas leucodermas, com oclusão normal, todos os dentes permanentes, tomando-se as telerradiografias aproximadamente 2 a 3 anos antes da menarca e depois dela. Analisaram a AFAT (N-Me), a AFAS (N-ENA) e a AFAI (ENA-Me), concluindo que existe uma grande variação na quantidade e época de crescimento para todas as variáveis, sendo que o pico de velocidade de 
crescimento para a AFAS ocorreu entre os 11 e 12 anos e para a AFAI, dos 12 aos 13 anos. Quanto mais precoce a menarca, mais precoce o pico de velocidade de crescimento, sendo que o maior crescimento vertical anterior ocorreu antes da menarca na maioria dos casos. Além disso, verificaram que a quantidade de crescimento durante o estudo foi similar para a AFAI e AFAS.

Sabe-se que o crescimento rotacional da mandíbula no sentido horário resulta em um aumento da altura facial ântero-inferior. Essa rotação, segundo PEARSON $^{156}$, em 1978, ocorre quando as estruturas anteriores crescem mais do que as posteriores, isto é, a altura do processo alveolar excede o aumento vertical do côndilo, ou quando a base craniana se horizontaliza, resultando em uma posição mais superior da fossa glenóide.

Avaliando as alterações nas dimensões faciais e suas relações, ocorridas entre os 5 e os 25,5 anos de idade, BISHARA; JAKOBSEN; BISHARA ${ }^{22}$, em 1984, analisaram as telerradiografias de 35 jovens (20 do gênero masculino e 15 do feminino), dividindo-os em 3 grupos: Grupo $\mathrm{F}$ dos 5 aos 10 anos. Grupo II- dos 10 aos 15 anos; Grupo III- dos 15 aos 25,5 anos. Analisaram as medidas relativas à altura facial anterior (N-ENA; N-Me; N-ENA/N-Me), à altura facial posterior (Ar-Go, S-Go e Ar-Go/S-Go) e a relação entre a AFP e AFA (S-Go/N-Me, SN.PM, SN.Gn), verificando que N-ENA e N-ENA/N-Me aumentaram significativamente no grupo I em ambos os gêneros. Quanto à AFP, no gênero masculino não houve diferença estatística nos 3 períodos estudados. No feminino, o aumento foi significante no Grupo I. Quanto à proporção Ar-Go/S-Go, houve diminuição no Grupo I e aumento nos Grupos II e III. A proporção S-Go/N-Me e o ângulo SN.PM alteraram mais no gênero masculino do que no feminino, no Grupo III. Em geral, a maioria das 
alterações no gênero feminino ocorreram nos Grupos I e II e no masculino, houve distribuição nos 3 períodos de crescimento.

Para compararem a altura facial anterior e a posterior nos 3 tipos faciais, BISHARA \& JAKOBSEN ${ }^{21}$, em 1985, estudaram uma amostra de 20 meninos e 15 meninas dos 5 aos 25,5 anos, observando que aos 25 anos, no gênero masculino, a AFA (N-Me) foi significantemente maior na face longa; já a AFP (Ar-PM) foi significantemente maior no gênero feminino com face curta. Os dados obtidos indicaram que $77 \%$ da amostra demonstrou o mesmo tipo facial dos 5 aos 25 anos, significando que há uma acentuada tendência de se manter o mesmo tipo facial com a evolução do crescimento.

A afirmação de que o padrão de crescimento facial é estabelecido em idades precoces, antes mesmo da irrupção dos primeiros molares permanentes foi realizada por NANDA ${ }^{149}$, em 1988. O autor estudou os padrões de crescimento facial em 32 jovens sem distinção de gênero, com idades entre 3 e 18 anos, leucodermas, não submetidos a tratamento ortodôntico, com mordida aberta ou sobremordida profunda esqueléticas. Concluiu que a mordida aberta anterior geralmente apresenta a AFAI (ENA-Me) aumentada e a sobremordida profunda caracteriza-se pela AFAS (N-ENA) aumentada. A AFP (S-Go) e a altura do ramo (Ar-PM) não diferem significantemente entre a mordida aberta anterior e a sobremordida profunda.

Com o propósito de se estudar o crescimento facial entre as idades de 13 anos e 4 meses e 17 anos e 10 meses, JANSON ${ }^{101}$, em 1990, utilizou a análise cefalométrica de McNamara. para analisar uma amostra de 31 jovens do gênero masculino e 29 do gênero feminino acompanhados 
longitudinalmente. No gênero masculino, as telerradiografias foram obtidas nas idades médias de 13 anos e 6 meses, 15 anos e 7 meses e 17 anos e 10 meses e no gênero feminino, nas idades de 13 anos e 4 meses, 15 anos e 5 meses e 17 anos e 8 meses. O período entre a primeira e a segunda telerradiografias foi denominado de primeiro período de crescimento e entre a segunda e a terceira telerradiografias, de segundo período de crescimento. Os resultados demonstraram que, no gênero masculino, ocorreu uma diminuição significante no ângulo do plano mandibular (PoOr.GoMe) no primeiro período de crescimento enquanto que no gênero feminino, houve uma diminuição significante deste mesmo ângulo nos dois períodos de crescimento estudados.

Com a finalidade de se estudar as alterações verticais ocorridas em 20 anos, FORZBERG et al. ${ }^{69}$, em 1991, selecionaram uma amostra de 30 adultos (15 do gênero feminino e 15 do masculino) dos 25 aos 45 anos de idade. Durante esse período, observaram que a AFAT aumentou em média 1,6mm, sendo que 4/5 desse aumento ocorreu na AFAI, principalmente devido ao aumento em altura dos processos alveolares na região posterior.

Objetivando estudar a influência que os componentes dentoalveolares e esqueléticos exercem sobre as alturas faciais e, conseqüentemente, sobre a rotação mandibular, NIELSEN ${ }^{152}$, em 1991, observou que os pacientes que apresentam um crescimento do côndilo para cima e para frente, geralmente apresentam a AFAI reduzida e a sobremordida acentuada. Já os pacientes que apresentam a face longa, com a AFAI acentuadamente aumentada, apresentam um desenvolvimento do côndilo mais para posterior e geralmente encontram-se com mordida aberta anterior e Classe I ou II associadas. Os 
fatores que determinam o aumento da AFAI são a irrupção dos dentes posteriores e a quantidade de deslocamento para baixo das suturas maxilares, ao passo que os fatores determinantes do aumento da altura facial posterior (AFP) são o deslocamento para baixo da fossa têmporomandibular e o crescimento condilar. Assim, quando o crescimento vertical do côndilo excede o crescimento dentoalveolar, a mandíbula tem uma rotação antihorária. Os pacientes com crescimento condilar para posterior apresentam quantidades de crescimento similares da AFA e AFP e a mandíbula translada durante o crescimento, sem rotação. Entretanto, se a AFA se desenvolver mais que a AFP, a rotação mandibular é horária, podendo causar uma mordida aberta anterior, dependendo da compensação vertical dentoalveolar. Quando o tratamento ortodôntico é instituído, deve-se ter um cauteloso controle vertical, pois a mecânica é extrusiva, havendo possibilidades de rotação mandibular no sentido horário, que é indesejável para o padrão de crescimento vertical, principalmente na Classe II.

Estudando telerradiografias de 124 meninos com idade média de 10 anos, não submetidos a tratamento ortodôntico, KERR \& LANFORD $^{107}$, em 1991, objetivaram verificar as alterações da AFAI com o decorrer da idade. Concluíram que a distância ENA-Me está entre as dimensões lineares de maior variabilidade, tanto na Classe I, como na Classe II ou III. Sabendo-se que esta dimensão cresce até o final da segunda década de vida, ela é mais suscetível às influências ambientais e, portanto, ao tratamento ortodôntico.

Para observarem as possíveis alterações nas dimensões faciais verticais ocorridas com o crescimento, VAN DER BEEK et al. ${ }^{207}$, em 1991, estudaram uma amostra de 72 meninas com idades entre os 7 e 14 anos. Propuseram o 
estudo de um polígono formado pela altura facial anterior (AFA), pela altura facial posterior e pelo ângulo do plano mandibular (SN.GoGn). Concluíram que havia pouca correlação entre os parâmetros de crescimento das alturas faciais anterior e posterior, os quais apontaram para a existência de um crescimento e desenvolvimento independentes de ambas as partes. Entretanto, a correlação entre a AFA e SN.GoGn foi altamente significante, demonstrando que as alterações durante o crescimento relacionam-se mais à altura facial anterior do que com a altura facial posterior. As diferenças entre a mordida aberta e a sobremordida localizam-se normalmente na altura facial anterior. Outra conclusão interessante deste trabalho foi a constatação de que as meninas que inicialmente apresentam uma altura facial anterior relativamente pequena crescem mais devagar do que as que têm uma altura facial anterior mais longa.

Em 1992, para relacionarem as velocidades de crescimento da AFAS e da AFAI, LIGTHEN-BAKKER et al. ${ }^{117}$ estudaram 32 meninas e 28 meninos entre 7 e 22 anos, com oclusão normal, verificando que aqueles que apresentaram uma taxa rápida de crescimento da AFAS (N-ENA), mostraram uma baixa taxa de crescimento da AFAI (ENA-Me) e, conseqüentemente, tiveram uma tendência a apresentar sobremordida profunda. Já os que apresentaram uma baixa taxa de crescimento da AFAS, mostraram uma rápida taxa de crescimento da $\mathrm{AFAI}$ e uma tendência à mordida aberta anterior.

Num estudo cefalométrico longitudinal, cujo objetivo foi estudar as alterações dimensionais do crescimento em padrões faciais diferentes, KARLSEN $^{106}$, em 1994, utilizou uma amostra composta por 30 pacientes do 
gênero masculino, cujas telerradiografias foram tomadas aos 6, 12 e 15 anos de idade, sendo divididos em dois grupos: os que apresentavam valores altos e baixos para o ângulo do plano mandibular, respectivamente. Observou-se que, embora os dois grupos apresentassem uma diminuição do ângulo do plano mandibular com o crescimento, houve tendência para que o grupo com ângulo do plano mandibular baixo, principalmente dos 6 aos 12 anos, tivesse uma rotação anti-horária mais acentuada da mandíbula em relação ao outro grupo. Dos 12 aos 15 anos de idade, a rotação mandibular anti-horária foi semelhante entre os grupos.

Por meio de uma amostra de oclusão normal com idades variando dos 5 aos 45 anos, BISHARA \& JAKOBSEN ${ }^{24}$, em 1998, analisaram as correlações entre o trespasse vertical e as alturas faciais, concluindo que as mesmas são baixas, não sendo úteis clinicamente. Existem outros fatores, como o crescimento do processo alveolar, que podem influenciar as alterações do trespasse vertical de maneira mais significativa.

$\mathrm{GONDIM}^{78}$, em 1999, realizou um estudo cefalométrico visando estudar o crescimento vertical da face. Para isso, determinou os valores para a sobremordida, para as alturas faciais e dentárias e para os ângulos de crescimento, a significância dos valores entre as idades, o dimorfismo entre os gêneros e as variáveis que contribuem para a sobremordida e para as alturas faciais ântero-inferior e póstero-inferior. A amostra constituiu-se de 233 telerradiografias em norma lateral oriundas de 37 jovens leucodermas do gênero masculino e 38 do feminino, sem mutilações nos arcos dentários e sem tratamento ortodôntico, que apresentavam as radiografias nas idades de 6, 9,12, 15 e 18 anos. Constatou que a sobremordida aumentou seus valores até 
os 12 anos, com posterior redução e estabilização, sendo influenciada principalmente pelas alturas dentárias anteriores. As alturas faciais anteriores aumentaram progressivamente dos 6 aos 18 anos, de forma acentuada na AFAI, com valores maiores no gênero masculino. A AFAI apresentou alterações principalmente pelas alturas dentárias anteriores, pela sobremordida e pelas medidas dentárias, sugerindo um forte componente dentoalveolar. As alturas faciais posteriores progrediram até os 15 anos no feminino e até os 18 no masculino. A AFPI recebeu grande influência das alturas dentárias posteriores e dos ângulos de crescimento. Os ângulos de crescimento apresentaram uma suave tendência de crescimento vertical com redução dos valores com a idade, sem diferenças significantes e sem dimorfismo entre os gêneros.

Também neste ano, GURGEL ${ }^{81}$ avaliou, comparativamente, 15 jovens com má oclusão de Classe II, $1^{\text {a }}$ divisão e 25 jovens com oclusão normal para se determinar os efeitos da correção ortodôntica ao final do tratamento e dois anos após o término. Os 15 jovens foram tratados ortodonticamente por meio do uso do aparelho fixo superior e inferior (técnica do Arco de Canto Simplificada) com extração dos quatro primeiros pré-molares. A idade deste grupo variou de 12 anos e 10 meses e 18 anos e 10 meses. Durante os dois anos após o término do tratamento, observou-se a ocorrência de incrementos que, embora reduzidos, exibiram-se de modo mais marcante no sentido vertical e com predominância no grupo controle.

As alturas faciais anteriores superior e inferior são variáveis totalmente independentes entre si, segundo LINDER-ARONSON; WOODSIDE ${ }^{119}$, em 2000. Já a altura facial ântero-inferior é acentuadamente dependente da 
direção de crescimento mandibular, bem como dos fatores ambientais relacionados a ela, como a respiração bucal.

\section{3- AS PROPORÇÕES FACIAIS VERTICAIS}

Nos itens anteriores, pôde-se observar que o estudo das proporções faciais é de longa data, havendo ainda uma controvérsia na literatura quanto à sua constância ou não durante o processo de crescimento e desenvolvimento craniofacial. Porém, no geral, constata-se que os estudos mais recentes sobre esse assunto concordam quanto à alteração nas proporções faciais.

O estudo das proporções faciais diminui as chances de erro, pois não recebe influência do aumento das imagens radiográficas, segundo WEINBERG; KRONMAN ${ }^{210}$, em 1966. Além disso, pelo fato da estética ser um sentimento muito pessoal e subjetivo, a avaliação das proporções faciais é muito mais útil do que a avaliação estética por si só.

O primeiro autor a defender a idéia de "constância" do padrão de crescimento foi BRODIE ${ }^{33}$, em 1941. Em sua amostra, constituída de 21 crianças do gênero masculino, com oclusão normal, e faixa etária variando dos 3 meses aos 8 anos de idade, observou que aproximadamente aos 2 anos de idade, a altura facial superior, AFAS (N-ENA), representava $43 \%$ da altura facial anterior total (AFAT), apresentando estabilidade com o crescimento. Sua principal conclusão foi que após o estabelecimento da dentadura decídua, ou seja, após os 24 meses de vida, a proporção entre a AFAS e a AFAT 
permanecia constante com o crescimento. No ano seguinte, suas observações foram novamente confirmadas quando estudou longitudinalmente $\mathrm{o}$ crescimento e desenvolvimento craniofacial desde o nascimento até a fase adulta.

A estabilidade das proporções faciais, independentemente da idade, também foi verificada por THOMPSON \& BRODIE ${ }^{199}$, também em 1942. Comparando pacientes de diferentes faixas etárias, os autores relataram que a altura facial ântero-superior (AFAS), medida do ponto násio à espinha nasal anterior, representa cerca de $43 \%$ da altura facial anterior total (AFAT), distância do násio ao mento e, conseqüentemente, a altura facial anteroinferior (AFAI) representa $57 \%$ desta proporção, independentemente da idade.

Em concordância com BRODIE ${ }^{33}$, BRODIE $^{34}$ e THOMPSON \& BRODIE $^{199}$, os pesquisadores HERZBERG \& $\mathrm{HOLIC}^{89}$, no ano seguinte, também observaram que a distância N-ENA representa uma média de 43,51\% da AFAT. Eles estudaram antropometricamente a altura facial de 326 crânios humanos adultos de diferentes raças, concluindo que as proporções faciais não apresentaram diferenças raciais significativas, assim como o atrito dos dentes não alterou as proporções da altura facial inferior, como já era de se esperar.

Com o objetivo de se estabelecer valores padrão para a análise facial no sentido vertical, WYLIE \& JOHNSON ${ }^{216}$, em 1952, realizaram um valioso estudo cefalométrico avaliando as proporções faciais de 171 pacientes, sendo 97 do gênero masculino e 74 do feminino, com idades entre 11 e 13 anos. 
Para isso, utilizaram as seguintes medidas: altura facial total (AFT)- distância do násio ao mento, composta pela altura facial superior, medida do násio à espinha nasal anterior (ENA), e pela altura facial inferior, ou seja, da ENA ao mento; borda inferior da mandíbula- distância do mento ao gônio; ramo mandibular- distância do gônio ao ponto mais superior do côndilo e ângulo condilar- intersecção das linhas côndilo- gônio e gônio-mento. Com base no valor da AFT, classificaram-se as faces em normais, regulares e desfavoráveis, observando que nas primeiras, o ângulo condilar era menor, o bordo inferior da mandíbula mais longo e a AFT maior do que nos outros dois tipos faciais. Além disso, nas faces normais, a AFS correspondia a $45 \%$ da AFT e a AFI, a 55\%. Os autores também observaram que a face adquire um aspecto cada vez mais desfavorável quando a AFI aumenta em relação à AFT, o ramo ascendente apresenta-se curto, o ângulo do plano mandibular encontra-se aumentado e a fossa glenóide do osso temporal está localizada numa posição relativamente mais alta que o normal.

Num estudo longitudinal em 55 crianças dos 4 aos 12 anos de idade (27 meninos e 28 meninas), MEREDITH; KNOTT; HIXON ${ }^{137}$, em 1958, utilizaram o índice AFAS/AFAI. Concluíram que a AFAS aumenta suavemente em relação à AFAI de acordo com a idade, ou seja, aos 4 anos a proporção da AFAS em relação à AFAI é de 71,7\% e aos 12 anos, passa para $79,2 \%$. Também não houve dimorfismo entre os gêneros.

A proporção entre a altura facial posterior e a anterior foi analisada por SCHUDY $^{184}$, em 1964, bem como a porcentagem entre a profundidade e a altura facial em 270 adolescentes com idades entre 10 e 14 anos com más oclusões que justificariam o tratamento ortodôntico. Observou-se que as 
proporções estudadas variaram de acordo com o padrão de crescimento, ou seja, as dimensões verticais e suas proporções identificam mais apropriadamente os tipos faciais do que as dimensões ântero-posteriores. Com base nos valores médios do ângulo do plano mandibular (SN.GoMe) de $33^{\circ} \mathrm{e}$ do ângulo do plano palatino e o plano mandibular (ENA-ENP.GoMe) de $16^{\circ}$, dividiu-se a amostra em 3 grupos classificados em tipos médio, retrognata e prognata. Assim, a profundidade facial corresponde a $76 \%$ da altura, em média, sendo que nos retrognatas esta porcentagem era de $70 \%$ e nos prognatas, de $80 \%$. A AFAS (N-ENA) não apresentou diferenças estatisticamente significantes entre os tipos faciais, o que se permitiu concluir que a diferença encontra-se na AFAI, que em média corresponde a 56\% da AFAT, nos retrognatas, 59,5\% e nos prognatas, 54,4\%. Pelas várias medidas do estudo, o autor conseguiu correlacionar positivamente o ângulo SN.GoMe com os tipos faciais, relatando que esta seria a medida da "divergência facial" e sugerindo os termos "hipo e hiperdivergentes" para os extremos dos valores da divergência facial. Em relação ao tratamento ortodôntico, SCHUDY também relatou que nos "hipodivergentes" a altura facial posterior excede a anterior, sendo que nos casos de Classe II, os molares superiores devem ser distalizados, evitando-se as extrações. Já em relação aos pacientes "hiperdivergentes", a altura facial está desproporcional em relação à profundidade e que a AFAI encontra-se mais aumentada em relação à posterior. Portanto, deve-se evitar o uso dos elásticos intermaxilares e, sempre que necessário, recomenda as extrações dentárias para o controle da dimensão vertical.

Objetivando-se estudar as alturas faciais entre os 5 e os 15 anos de idade, numa amostra com oclusão normal composta por 20 meninos e 20 meninas, 
JONES \& MEREDITH ${ }^{104}$ concluíram que a AFAS e a AFAT são maiores nos meninos do que nas meninas, sendo que no gênero masculino, aos 5 anos, a AFAS representa $44 \%$ da AFAT aumentando para $46 \%$ aos 15 anos de idade. No gênero feminino, varia de 44,5 para $46,5 \%$ na mesma faixa etária e entre os 11 e 15 anos de idade, a AFAS permanece praticamente constante em ambos os gêneros.

Utilizando o quociente de JARABAK, proposto por SIRIWAT \& JARABAK $^{186}$, AIDAR \& SCANAVINI ${ }^{2}$ concluíram que os grupos de oclusão normal e Classe II, $2^{\text {a }}$ divisão apresentaram um padrão hipodivergente

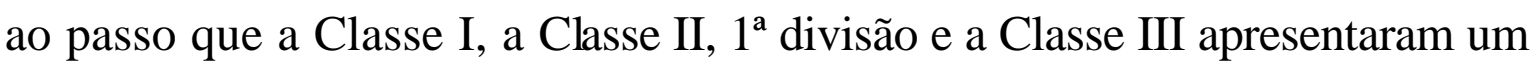
padrão de crescimento neutro, ou seja, quando a proporção entre a altura facial posterior (S-Go) apresenta-se entre 59 a $63 \%$ da altura facial anterior (N-Me).

Por meio de uma amostra composta por 79 crianças brasileiras, leucodermas, com idades entre 8 e 11 anos, sendo 33 do gênero masculino e 46 do feminino, todas com má oclusão de Classe I não tratadas, na fase de dentadura mista, LOCKS $^{121}$, em 1996, estudou, num intervalo de tempo que variou de 8 a 16 meses, as alturas faciais anterior e posterior. Verificou que o crescimento das dimensões faciais anterior e posterior mantiveram-se constantes no período de tempo estudado. Além disso, o Índice de Horn foi de 0,66, com tendência a aumentar com a idade. As proporções faciais anteriores apresentaram-se praticamente constantes, com $42 \%$ para a altura facial ânterosuperior e 58\% para a inferior, sendo que esta última teve maior participação no aumento da altura facial anterior total. Não houve dimorfismo entre os 
gêneros, nem em relação às proporções faciais anteriores nem ao Índice de Horn.

D'CUNHA $^{55}$, em 1983, apresentou uma pesquisa utilizando-se a “análise quadrangular" de DI PAOLO ${ }^{60}$ em adultos leucodermas, de ambos os gêneros, de 20 a 30 anos de idade, com oclusão normal. Ele observou que a proporção entre a altura facial póstero-inferior (AFPI) e a altura facial ânteroinferior (AFAI) era de 1:1,43, concluindo que a análise também pode ser aplicada aos adultos. A "análise quadrangular" de DI PAOLO ${ }^{60}$ indica qual o grau de proporcionalidade existente entre o crescimento vertical e horizontal.

Utilizando a mesma análise, em 60 leucodermas brasileiros, 31 do gênero masculino e 29 do feminino, ESTRIPEAUT LOPEZ ${ }^{67}$, em 1988, estudou longitudinalmente o comportamento da proporcionalidade da face inferior dos 13 anos e 3 meses aos 17 anos e 9 meses de idade. Encontrou uma proporção entre AFPI e AFAI de 1: 1,53 para o gênero masculino e 1: 1,54 para o feminino.

Em 1990, realizando um estudo para investigar quais as melhores, mais práticas e confiáveis medidas lineares para a análise das proporções verticais da face, TANAKA ${ }^{197}$ concluiu que os pontos esqueléticos que se adequaram foram násio $(\mathrm{N})$, subespinhal $(\mathrm{A})$ e o gnátio $(\mathrm{Gn})$ e os pontos tegumentares foram glabela $(\mathrm{Gl})$, subnasal $(\mathrm{Sn})$ e o ponto intermediário entre o mento e gnátio no tecido mole (MG). O autor ainda observou que a medida Gl-Sn apresentou valor equivalente à medida Sn-MG, referente ao terço inferior do mesmo modo que N-A e A-Gn. 
A proporção entre a AFPI e a AFAI em jovens com oclusão normal encontrada nestes estudos confirmam o que HELLMAN ${ }^{83}$ já pontificava, em 1932, ou seja, que a face cresce verticalmente mais na parte posterior do que na anterior, sendo essas mudanças mais acentuadas no gênero masculino.

\section{4- O CONTROLE VERTICAL NO TRATAMENTO ORTODÔNTICO COM E SEM EXTRAÇÕES}

Embora amplamente estudado, o tratamento ortodôntico com extração dos quatro primeiros pré-molares e seus efeitos nas alturas faciais ainda são alvo de certa polêmica. Há autores que contra-indicam a extração de prémolares, principalmente nos casos de Classe II, pois relatam que a mesialização dos molares provoca o fechamento do ângulo do plano mandibular de modo acentuado, diminuindo a dimensão vertical (BOWBEER $^{28}$, 1987; PERRY ${ }^{160}$, 1973; TULLEY ${ }^{202}$, 1959; WYATT $^{213}$, 1987). Essa assertiva, entretanto, não apresenta nenhuma comprovação científica. Pelo contrário, muitos autores concordam que não há alteração significante do ângulo do plano mandibular (BISHARA et al. ${ }^{23}, 1995$; CAPELOZZA FILHO et $\mathrm{al}^{39}, \quad 2000$; KOCADERELI $^{112}, \quad$ 1999; STAGGERS $^{193}$, 1994; TANER-SARISOY; DARENDELILER ${ }^{198}$, 1999;). Numa apresentação de um caso clínico, GARLINGTON ${ }^{74}$, em 1987, demonstrou que, mesmo após a remoção precoce dos dentes decíduos e a enucleação dos segundos pré-molares, conseguiu promover uma diminuição do ângulo do plano mandibular de somente $0,8^{\circ}$. Num outro caso clínico, PEARSSON $^{157}$ conseguiu um fechamento de $3,9^{\circ}$ neste mesmo ângulo por 
meio da extração de pré-molares e da utilização de uma mentoneira vertical antes e durante o tratamento ortodôntico. Entretanto, não houve um estudo pós-tratamento para se determinar se o ângulo do plano mandibular retornava ao seu valor original após o tratamento.

A importância do controle vertical durante o tratamento ortodôntico veio à tona somente a partir de 1968, com os estudos de SCHUDY $^{182}$. Entretanto, apesar dele recomendar a extração dos primeiros pré-molares, sempre que possível, para o controle da dimensão vertical, seus conceitos e experiência clínica a este respeito ainda não foram suficientes para incutir os ortodontistas da época. Porém, foram úteis para despertar um certo interesse dos pesquisadores.

CREEKMORE $^{51}$ já havia relatado em 1967 que o crescimento vertical tem diferentes efeitos sobre os vários tipos faciais, e deve ser estimulado ou inibido de acordo com as necessidades de cada paciente.

Assim, objetivando descrever as implicações clínicas do controle vertical, bem como as alterações decorrentes do tratamento ortodôntico, SPYROPOULOS \& ASKARIEH ${ }^{191}$, em 1976, pontificaram que em pacientes dolicofaciais, o controle vertical é essencial para um resultado estético satisfatório. Em pacientes com padrão de crescimento horizontal, o controle vertical não é tão crítico, pois o próprio crescimento o compensa durante o tratamento ortodôntico.

O sucesso da correção ortodôntica costuma ser avaliado pela relação dentária ântero-posterior; no entanto, WARD ${ }^{209}$, em 1994, advogou que a 
movimentação horizontal da dentição depende diretamente de um adequado controle vertical do complexo maxilomandibular. Por isso, é imprescindível que estejam claros os objetivos do tratamento, para que se alcance a correção eficaz da má oclusão, tanto no sentido horizontal como no vertical.

Com o intuito de verificarem os efeitos da mecânica ortodôntica e a influência do crescimento na correção da Classe II, HULTGREN et $\mathrm{al}^{92}$., em 1978, avaliaram a proporção entre a altura facial anterior e a posterior. Uma diminuição nesta proporção indicaria um maior crescimento na região dos côndilos do que nos molares, alterando a rotação mandibular de modo favorável para a correção da Classe II. Um aumento nessa proporção caracterizaria um efeito oposto de rotação mandibular. Constataram que o tratamento ortodôntico alterou estes parâmetros, aumentando a tendência de rotação mandibular; entretanto, após o término do tratamento, esta proporção atinge valores próximos aos observados em pacientes com crescimento normal não tratados. Assim, concluíram que, após o término do tratamento, o padrão de crescimento retornou ao observado ao início da correção ortodôntica.

Muitos estudos estavam se concentrando no controle vertical dos molares superiores sem, no entanto, avaliar se a extrusão dos molares inferiores também influenciaria significantemente a altura facial ânteroinferior, ao fazer com que a mandíbula apresentasse uma rotação horária, segundo PEARSON ${ }^{157}$, em 1973. O trabalho realizado por RICKETTS ${ }^{171}$, em 1960, foi um dos poucos com esse objetivo. Ele já havia observado que os molares inferiores se desenvolveram no sentido vertical aproximadamente 3,3 milímetros durante 30 meses de tratamento, sendo que o grupo controle 
(composto por Classe I e Classe II) apresentou um aumento de 1,5 milímetros durante o mesmo intervalo de tempo. CREEKMORE ${ }^{51}$, em 1967, também observou um aumento de 1,59 milímetros em jovens não tratados. Para os casos tratados com extrações, DOUGHERTY ${ }^{62}$, em 1968, encontrou 3,4 milímetros de aumento para os casos com extração e preparo de ancoragem; para os casos sem extração e com preparo de ancoragem, 2,6 milímetros. O autor ainda relatou que para cada milímetro de extrusão posterior há uma abertura de 3 milímetros na região anterior.

Com o desenvolvimento e aprimoramento cada vez maior da cefalometria, os autores começaram a verificar que as alterações verticais advindas do tratamento ortodôntico também se encontravam relacionadas ao padrão de crescimento facial.

Um dos primeiros trabalhos neste contexto é o de CROSS $^{52}$, de 1977. Por meio de um estudo longitudinal das direções de crescimento facial antes, durante e após o tratamento ortodôntico, observou que nem todas as faces respondem da mesma maneira. Algumas mantêm a direção de crescimento original enquanto outras apresentam uma rotação mandibular no sentido horário.

Entretanto, já na década de 60, algumas pesquisas buscavam também correlacionar os efeitos do tratamento ortodôntico com e sem extração dos primeiros pré-molares, a ancoragem extrabucal e o tipo de padrão facial.

$\mathrm{KING}^{110}$, em 1957, por exemplo, realizou uma avaliação cefalométrica do tratamento da Classe II, $1^{\text {a }}$ divisão, na dentadura pemanente, utilizando o 
aparelho extrabucal cervical associado ao aparelho fixo de "edgewise". Observou que, nos casos tratados com extração de pré-molares, a correção da Classe II ocorreu pela menor movimentação dos molares superiores no sentido ântero-posterior, enquanto os inferiores apresentaram maior mesialização.

Objetivando estudar a influência do tratamento ortodôntico associado à ancoragem extrabucal cervical sobre o desenvolvimento do complexo craniofacial, WIESLANDER ${ }^{211}$, em 1963, analisou as telerradiografias de 30 jovens, na fase de dentadura mista, com Classe II tratados com ancoragem extrabucal cervical, comparando com um grupo controle com oclusão normal. Quanto à dimensão vertical, constatou um significativo aumento da altura facial ântero-inferior do grupo tratado, fato este que pode estar relacionado à alteração na posição dos molares superiores; entretanto, observou um crescimento vertical significante dos côndilos mandibulares neste grupo, mantendo inalterada a inclinação do plano mandibular. Concluiu assim que a ancoragem extrabucal cervical auxiliou na alteração da direção do padrão de crescimento facial.

Estudando a altura facial anterior e suas proporções, WEINBERG \& KRONMAN $^{210}$, em 1966, compararam 30 crianças com oclusão normal e 30 crianças com sobremordida profunda. A AFAT foi medida do N ao Gn. Os autores não observaram diferenças nas proporções verticais entre os grupos. Eles concluíram também que a correção ortodôntica da sobremordida profunda não alterou significantemente a proporção AFAI/AFAT, pois relataram que os músculos mastigatórios são fatores determinantes desta proporção, agindo sempre no intuito de manter o comprimento de repouso 
muscular. A correção da sobremordida acentuada foi principalmente dentoalveolar, com participação maior dos incisivos inferiores.

Discordando dos resultados de WEINBERG \& KRONMAN $^{210}$, SCHUDY $^{182}$, em 1968, observou que, apesar de se poder intruir os incisivos no tratamento da sobremordida acentuada, há também uma forte tendência de haver extrusão dos mesmos no período pós-tratamento. É preferível, sempre que possível, extruir o molar a intruir o incisivo inferior. Além disso, afirmaram que o movimento para baixo dos molares superiores é o mais importante fator de crescimento no estabelecimento da altura facial. O crescimento para baixo do molar superior excede o do incisivo superior na proporção de 2:1. MEROW ${ }^{138}$, em 1962, encontrou um coeficiente de correlação de 0,80 deste fator com o aumento da altura facial anterior, enquanto CREEKMORE ${ }^{51}$, em 1967, encontrou um valor de 0,62. Aproximadamente $70 \%$ do crescimento vertical da face ocorre devido ao crescimento para baixo dos molares superiores e $30 \%$ dos molares inferiores. O crescimento maxilar e o condilar apresentam direções opostas: enquanto a maxila tende a levar o mento para baixo e para trás, o crescimento condilar o leva para frente e para cima. Assim, um crescimento maxilar bem controlado tem o mesmo efeito de um maior crescimento condilar.

Avaliando uma amostra de 100 pacientes com idades entre 12 e 15 anos, GEBECK \& MERRIFIELD ${ }^{75,76}$, em 1989, objetivaram verificar se havia diferença dentoalveolar ou esquelética entre aqueles cujo resultado do tratamento ortodôntico foi satisfatório e os que foram considerados desfavoráveis. Todos haviam sido tratados com a mecânica proposta por TWEED $^{203}$ e foram comparados a um grupo controle. Concluíram que os 
casos tratados com sucesso não apresentavam diferença com o grupo controle, ou seja, o resultado do tratamento foi harmonioso com o processo de crescimento normal: a altura facial posterior desenvolveu-se mais que a altura facial anterior. Já quando o grupo de casos com resultados desfavoráveis foi comparado ao grupo controle, observaram que a altura facial anterior aumentou acentuadamente. Esta diferença também foi observada quando este grupo foi comparado aos casos com sucesso. $\mathrm{O}$ aumento excessivo da altura facial anterior resultou num aumento da convexidade facial, fator responsável pelo insucesso dos casos.

Comparando 22 pacientes com má oclusão de Classe I tratados com extração dos quatro primeiros pré-molares e 22 pacientes tratados com extração dos quatro segundos molares, STAGGERS ${ }^{192}$, em 1990, não observou diferenças significantes nas alterações do ângulo do plano mandibular, nem no perfil facial e nas angulações dos terceiros molares.

A decisão de extração de dentes na Ortodontia depende das discrepâncias esqueléticas e dentoalveolares sagitais e verticais. Sendo assim, YAMAGUCHI \& NANDA ${ }^{217}$, em 1991, realizaram um estudo sobre os efeitos do tratamento ortodôntico com e sem extrações no posicionamento mandibular. Avaliaram pacientes com más oclusões de Classe I e Classe II, $1^{\text {a }}$ divisão, sendo 48 tratados sem extrações e 73 com extrações. Verificaram que as alterações verticais no complexo nasomaxilar e na posição dos molares superiores e inferiores podem resultar em uma rotação posterior da mandíbula. No grupo tratado com extrações dentárias, observaram uma diferença significante entre os diversos tipos de força extrabucal utilizados quanto à altura facial ântero-inferior e à extrusão dos molares superiores em 
relação à linha SN. Concluíram que as alterações na posição dos molares, nos sentidos vertical e horizontal, estiveram relacionadas ao tipo de força aplicada, mas não com a realização ou não de extração de pré-molares.

Estudando a influência do tratamento ortodôntico com e sem extração dos quatro primeiros pré-molares em dois tipos de padrão facial, braqui e dolicofaciais, KLAPPER et al. ${ }^{111}$, em 1992, classificaram esses pacientes, utilizando o Índice facial de RICKETTS ${ }^{172}$. Este índice é composto por cinco medidas angulares: profundidade facial, eixo facial, ângulo do plano mandibular, altura facial inferior e arco mandibular. Dessa forma, analisaramse as alterações no eixo facial e a correlação entre este e o movimento ânteroposterior dos molares superiores. Como resultados deste trabalho, os autores observaram uma correlação positiva entre tais medidas cefalométricas em ambos os padrões faciais quando tratados sem extrações dentárias. Já nos grupos tratados com extração, houve uma suave correlação. Não se observaram diferenças estatisticamente significantes nas alterações do eixo facial entre os grupos estudados, independentemente do tipo facial ou do plano de tratamento. Entretanto, houve indícios de que quanto maior a abertura do eixo facial (Ba-Na.Gn), maior o movimento distal dos molares superiores, em ambos os padrões faciais estudados.

Num estudo cefalométrico comparativo, BURKE \& JACOBSON ${ }^{36}$, em 1992, avaliaram as alterações verticais em pacientes com padrão de crescimento vertical e Classe II, $1^{\text {a }}$ divisão tratados com dois tipos de ancoragem extrabucal: cervical e occipital. Concluíram que não há diferenças significantes entre a ancoragem cervical e a occipital quanto à dimensão vertical e ao ângulo do plano mandibular. 
A utilização do Índice da Altura Facial (IAF) durante o tratamento ortodôntico foi proposta por $\mathrm{HORN}^{91}$, em 1992. Este índice, que permite que o profissional monitore direta e dinamicamente o controle vertical de cada caso, é a razão entre a altura facial posterior (PFH) e a anterior (AFH), medidas preconizadas por GEBECK \& MERRIFIELD ${ }^{75,76}$. O índice de HORN indica o sentido da rotação mandibular durante o tratamento ortodôntico e é particularmente útil no tratamento da Classe II, $1^{\text {a }}$ divisão, pois se a PFH aumentar mais rapidamente que a $\mathrm{AFH}$, o índice irá aumentar, colaborando para a obtenção de um perfil facial mais harmonioso, além de auxiliar na correção ântero-posterior da má oclusão, uma vez que a mandíbula sofre rotação no sentido anti-horário como nos casos de oclusão normal. Por outro lado, se a AFH aumentar mais do que a PFH, a mandíbula apresentará rotação horária, tornando o perfil ainda mais convexo e anti-estético. Logo, se durante o tratamento o índice estiver diminuindo, caberá ao profissional a revisão imediata do plano de tratamento e o controle mais rígido da altura facial, controlando a extrusão dos dentes posteriores e mantendo os planos palatino e oclusal mais próximos possíveis de suas posições iniciais.

Estudando os efeitos da extração dos primeiros pré-molares sobre a altura facial em pacientes com más oclusões de Classe I e Classe II, ângulo do plano mandibular acentuado (SN.GoMe maior que $36^{\circ}$ ), e extração dos quatro primeiros pré-molares, CUSIMANO; MCLAUGHLIN; ZERNIK ${ }^{53}$, em 1993, concluíram que, apesar de haver mesialização dos dentes posteriores durante a retração, o ângulo do plano mandibular permanece praticamente constante devido ao crescimento vertical e também pela própria extrusão causada pela mecânica ortodôntica. 
Buscando esclarecer os efeitos do tratamento ortodôntico sobre a altura facial ântero-inferior, CHUA; LIM; LUBIT ${ }^{45}$, em 1993, examinaram 174 pacientes divididos igualmente em Classe I e Classe II. Cada grupo foi subdividido de acordo com o tipo de tratamento: com ou sem extração dos quatro primeiros pré-molares. Para se diferenciar as alterações decorrentes do tratamento daquelas advindas do próprio processo de crescimento, os autores utilizaram um método no qual compararam seus resultados aos valores normais propostos pelo Centro de crescimento de Michigan. Dessa forma, a amostra empregada pôde ser ampliada, pela possibilidade de se compararem diferentes idades e intervalos de tempo, por exemplo. Os resultados obtidos demonstraram que os tratamentos sem extrações na Classe I e na Classe II estão associados ao aumento significante na altura facial ântero-inferior, ao contrário do tratamento com extrações, que não a alterou significativamente.

Com o objetivo precípuo de esclarecer a intrigante questão existente na literatura quanto à influência das extrações dos quatro primeiros pré-molares sobre a altura facial ântero-inferior, STAGGERS ${ }^{193}$, em 1994, comparou 38 casos com má oclusão de Classe I tratados com extração e 45 casos com Classe I tratados sem extração. As análises estatísticas demonstraram que não houve diferença estatística nas alterações verticais entre os grupos; ambos produziram um suave aumento na dimensão vertical. Segundo a autora, os resultados eram os esperados, pois na Classe I, o objetivo da ancoragem é manter a relação molar estável. Dessa forma, os dentes posteriores não necessitariam de mesialização, portanto não poderia haver diminuição perceptível da dimensão vertical. STAGGERS ${ }^{193}$ relatou ainda que, mesmo em pacientes com má oclusão de Classe II, $1^{\text {a }}$ divisão, a dimensão vertical não 
deve reduzir pois a própria mecânica ortodôntica é extrusiva (elásticos de classe II, preparo de ancoragem de Tweed e ancoragem extrabucal cervical). No entanto, sugere que estudos sejam realizados nas más oclusões de Classe II. KOCADERELI ${ }^{112}$, em 1999, também chegou a conclusões bastante semelhantes às de STAGGERS ${ }^{193}$.

Também no afã de se estabelecer as alterações nas alturas faciais após as extrações durante o tratamento e 6 anos após, VADEN; HARRIS; SINCLAIR $^{206}$, em 1994, estudaram o Índice de Horn em 23 pacientes do gênero feminino com Classe II, $1^{a}$ divisão tratadas com extração dos quatro primeiros pré-molares. Os resultados foram comparados a um grupo controle de 17 jovens com Classe II não tratados, concluindo que o tratamento ortodôntico proporcionou um aumento da altura facial posterior e essa alteração continuou após os 6 anos de tratamento. Assim, houve um aumento significante da razão AFP/AFA nos casos tratados, sendo que este aumento deve ser considerado o principal fator de manutenção da correção da Classe II. Concluíram também que se a Classe II for corrigida com um sistema de força que controle a dimensão vertical, haverá um crescimento mandibular mais favorável do que nos que não forem tratados ortodonticamente.

ZAHER; BISHARA; JAKOBSEN ${ }^{220}$, em 1994, analisaram cefalometricamente as alterações verticais durante e 2 anos após o tratamento ortodôntico nos diferentes tipos faciais. Utilizaram a proporção entre a AFA e a AFP, SN.GoGn e PoOr.GoGn para a determinação do padrão de crescimento facial. A amostra constou de 66 pacientes com Classe II, $1^{\text {a }}$ divisão, todos tratados sem extração, utilizando-se a técnica de "edgewise" e ancoragem extrabucal. Os três tipos de padrão facial não diferiram nas 
alterações pós-tratamento, exceto nas meninas com face longa, em que se observou um maior incremento na altura facial anterior e uma maior diminuição do comprimento do arco dentário superior. Os resultados desta pesquisa indicaram, segundo os autores, que o tipo facial não representa um papel importante na estabilidade dos casos.

As alterações dentofaciais e de tecido mole em casos de Classe II, $1^{\text {a }}$ divisão com e sem extração dos quatro primeiros pré-molares foram avaliadas e comparadas entre si por BISHARA et al. ${ }^{23}$ em 1995. A amostra foi dividida em dois grupos: 44 pacientes tratados com extração e 47 sem extração dos referidos dentes. Quanto às dimensões verticais, os autores observaram que não houve diferença significante na inclinação do plano mandibular entre os grupos, concordando com STAGGERS ${ }^{193}$ e discordando de BOWBEER $^{28}$.

Outro autor que demonstrou bastante interesse no controle vertical durante a correção ortodôntica de pacientes com padrão de crescimento facial vertical acentuado foi BILODEAU ${ }^{16}$ em 1995. Segundo ele, o importante é que o ângulo FMA seja mantido ou diminuído durante o tratamento ortodôntico.

Para ORTIAL ${ }^{153}$, em 1995, o padrão esquelético no sentido vertical constitui um fator que diferencia as más oclusões com um relacionamento dentário idêntico. Portanto, é obrigatória a análise das alturas faciais no diagnóstico de pacientes com Classe II, principalmente nos casos que requerem extrações. 
Por meio de uma revisão da Iteratura concernente ao dilema "extração x não extração" e a disfunção craniomandibular, MCLAUGHLIN; BENNETT $^{132}$, em 1995, concluíram que o tratamento ortodôntico com extração dos quatro primeiros pré-molares não diminui a altura facial anterior; pelo contrário, há a manutenção ou um suave aumento da mesma, causada pelo próprio processo de crescimento e pela extrusão dos dentes posteriores promovida pela mecânica ortodôntica.

MAGGIONCALDA $^{124}$, em 1997, apresentou o tratamento ortodôntico de um paciente com Classe II, $1^{\text {a }}$ divisão, apinhamento anterior acentuado, padrão de crescimento facial vertical, artrite juvenil crônica e retrognatismo mandibular. Apesar disto, a paciente foi tratada com extrações dos primeiros pré-molares em ambos os arcos dentários. O crescimento favorável inesperado e a diminuição significante no ângulo do plano mandibular durante um longo período de tratamento, proporcionaram um resultado bastante satisfatório.

Apesar do tratamento ortodôntico-cirúrgico de pacientes adultos com discrepância vertical ser bastante comum, muitas vezes, apenas o tratamento ortodôntico é uma opção bastante viável, fornecendo ao paciente uma face equilibrada e uma oclusão funcional satisfatória. Para isso deve-se observar os dois pontos-chave do tratamento: o diagnóstico diferencial e o controle vertical. Segundo VADEN ${ }^{205}$, em 1998, a hiperdivergência facial encontra-se relacionada com uma altura facial posterior diminuída devido ao ramo mandibular curto. A altura facial anterior, por sua vez, pode estar relacionada à direção de crescimento do ramo da mandíbula e à forma e posição da maxila, com as compensações dentoalveolares. 
Neste mesmo ano, HENRIQUES; FREITAS; HAYASAKI ${ }^{88}$ apresentaram as principais indicações e efeitos da ancoragem extrabucal occipital (I.H.G.) no tratamento de jovens com má oclusão de Classe II, $1^{\text {a }}$ divisão. A título de ilustração do assunto, apresentou-se também um caso clínico de uma paciente com Classe II, $1^{a}$ divisão com tendência vertical de crescimento e a maxila protruída que foi tratada com essa metodologia. Concluíram que o I.H.G. demonstrou ser um meio eficiente de controle do crescimento vertical da face, possibilitando muitas vezes um tratamento ortodôntico sem exodontias e com sensível melhora no perfil facial.

As alterações esqueléticas e dentárias que contribuem para a correção da Classe II sem extrações pela técnica de Begg foram avaliadas quantitativamente por NELSON; HANSEN; HÄGG ${ }^{151}$, em 1999. A amostra consistiu de 18 pacientes do gênero masculino, tratados com aparelho fixo por um período médio de 1,3 anos. Concluíram que as alterações que contribuíram para a correção da Classe II foram mais dentoalveolares. Verticalmente, os principais efeitos do tratamento foram o aumento do ângulo do plano mandibular e da altura facial ântero-inferior.

No entanto, TANER-SARISOY; DARENDELILER ${ }^{199}$, ainda em 1999, ressaltam a importância de se diferenciar os efeitos da extração dos primeiros pré-molares sobre as alturas faciais em relação aos diferentes padrões de crescimento e aos tipos de ancoragem extrabucal utilizados. Neste trabalho, 41 pacientes com idade média de 14 anos e 7 meses, que apresentavam má oclusão de Classe I ou de Classe II, $1^{\text {a }}$ divisão, foram tratados com a mecânica de "edgewise" e extração dos quatro primeiros pré-molares. Na primeira parte 
do trabalho, os pacientes foram avaliados quanto ao padrão de crescimento: meso e hiperdivergentes. Na segunda parte, foram avaliados quanto ao uso ou não do aparelho extrabucal. Os autores concluíram que nem o tratamento ortodôntico com extração dos quatro primeiros pré-molares nem o uso do extrabucal alteram significantemente o padrão de crescimento e que houve diferença estatisticamente significante entre meso e hiperdivergentes apenas quanto às alturas faciais superior e total.

Em 1999, KOCADERELI ${ }^{112}$ realizou um estudo com o objetivo de avaliar as alterações verticais que ocorreram em 40 pacientes com Classe I tratados ortodonticamente com extração dos quatro primeiros pré-molares, comparando-os com um grupo de 40 pacientes tratados sem extração dentária. Nenhum dos grupos utilizou ancoragem extrabucal. Os resultados obtidos demonstraram a inexistência de diferenças nas alterações verticais entre os casos tratados com e sem extrações de primeiros pré-molares. Houve diferença estatisticamente significante entre os grupos apenas na medida DMS-PTV, em que os casos com extração apresentaram mesialização quase três vezes maior que no grupo sem extração.

O estudo cefalométrico realizado por SANKEY et al. ${ }^{174}$, em 2000, avaliou a abordagem precoce sem extrações em pacientes com displasia esquelética vertical acentuada e atresia maxilar. Desse modo, 38 crianças aos 8,2 anos de idade foram tratadas por um período de 1,3 anos por meio de exercícios de vedamento labial, pelo expansor colado e por uma placa lábioativa do tipo Crozat. $\mathrm{O}$ expansor colado desempenhou a mesma função de um "bite-block" posterior. Os pacientes que apresentavam uma força insuficiente dos músculos da mastigação receberam uma mentoneira para a utilização por 
12 a 14 horas ao dia. As alterações cefalométricas foram comparadas a um grupo controle. Essa abordagem terapêutica foi capaz de alterar a posição dos côndilos numa direção ântero-superior, produzindo uma rotação mandibular anti-horária 2,7 vezes maior do que no grupo controle. A altura facial posterior aumentou significantemente mais do que no grupo controle e os molares superiores apresentaram uma intrusão relativa. Nos pacientes tratados, o ângulo articular aumentou, o ângulo goníaco diminuiu e o mento se posicionou 2 vezes mais para anterior que o grupo controle. $\mathrm{O}$ tratamento também diminuiu a sobressaliência e aumentou a sobremordida, pelo controle da altura facial ântero-inferior. Logo, os autores concluíram que esta mecanoterapia se faz eficaz nos pacientes hiperdivergentes que possuam discrepância nos outros 2 planos espaciais também.

Em um artigo publicado na Revista Dental Press de Ortodontia e Ortopedia Facial, em 2000, CAPELOZZA FILHO et al. $^{39}$ avaliaram as alterações verticais em casos de Classe II, $1^{\text {a }}$ divisão dentária com extração dos quatro primeiros pré-molares. A amostra foi composta por 8 pacientes do gênero masculino e 11 do gênero feminino, com idade média de 13 anos e 3 meses e diferentes padrões de crescimento. As grandezas cefalométricas angulares relacionadas ao padrão de crescimento não mostraram alteração com o tratamento ortodôntico. Quanto às medidas lineares verticais, observou-se que a altura facial posterior teve um maior aumento que a altura facial anterior na proporção de 1,12:1. Quanto às proporções das alturas faciais anteriores, constatou-se que a altura facial ântero-inferior não aumentou significantemente, o que seria um reflexo das exodontias. Além disso, a correção da sobremordida relacionou-se à extrusão dos molares inferiores e não à intrusão dos incisivos inferiores. 
As alterações do ângulo do plano mandibular e do eixo $\mathrm{Y}$ são exaustivamente estudadas nos jovens em crescimento, porém, AHN; SCHNEIDER $^{1}$, também em 2000, observaram que em adultos há poucos trabalhos existentes na literatura. Estas pesquisas relatam que há uma diferença essencial na fase de contenção e pós-contenção: enquanto nos adolescentes, há uma retomada do padrão de crescimento facial original, nos adultos há uma alteração permanente do ângulo do plano mandibular, pelo controle ou aumento da altura facial ântero-inferior, por exemplo. Por isso, o objetivo deste estudo foi avaliar as alterações mandibulares decorrentes do tratamento ortodôntico em adultos e verificar se as alterações verticais seriam mantidas na fase pós-tratamento. Porém, concluíram que tanto as medidas iniciais quanto as alterações decorrentes do tratamento não predizem o comportamento do ângulo do eixo Y na fase pós-contenção.

As alterações verticais na posição dos molares inferiores simultaneamente à manutenção do perímetro do arco por meio de um arco lingual fixo foram determinadas e quantificadas por VILLALOBOS; SINHA; NANDA $^{208}$, em 2000. A idade média foi de 10,4 anos e a duração do tratamento foi de 18,3 meses. Os resultados foram comparados a um grupo controle e indicaram que o arco lingual fixo é bastante útil para controlar o desenvolvimento dos molares inferiores, principalmente em pacientes hiperdivergentes. Nestes casos, os autores recomendam a instalação deste aparelho por volta dos 7 anos de id ade.

Para verificarem se a dimensão vertical, ao ser alterada significantemente pelo tratamento, apresentaria uma reversão ao valor 
original após o tratamento, podendo ser, neste caso, um dos principais fatores que levam à recidiva, BEATRICE; WOODS $^{12}$, em 2000, realizaram um interessante estudo cefalométrico. Apesar de relatarem que as faces hiperdivergentes são mais suscetíveis ao aumento da dimensão vertical durante o tratamento do que as hipodivergentes, seus resultados não concordaram com essa assertiva, pois nenhuma relação direta entre o padrão vertical e o eixo facial foi encontrada. Pôde-se observar que em pacientes hipodivergentes, ocorreu um mínimo de abertura do eixo facial durante o tratamento, podendo até mesmo apresentar um fechamento do mesmo após o tratamento. Por isso, RICKETTS ${ }^{170}$, em 1981, e outros pesquisadores recomendam que, em pacientes braquifaciais, as sobremordidas profundas devem ser reduzidas por meio da intrusão dos incisivos e não tanto pelo aumento da altura facial ântero-inferior. As alterações pós-tratamento mais freqüentemente relatadas são as recidivas nos trespasses horizontal e vertical.

Para se determinar a influência do padrão de crescimento vertical nas alterações oclusais ocorridas após o tratamento ortodôntico em pacientes tratados por um único ortodontista, PINTO; WOODS; CRAWFORD ${ }^{163}$, em 2000, utilizaram as telerradiografias de 60 pacientes (46 do gênero feminino e 14 do masculino), incluindo as fases pré-tratamento (T1), pós-tratamento (T2) e controle de no mínimo 6,5 anos (T3), bem como os respectivos modelos de gesso. A média de idade foi de 13,7 anos, sendo que 17 foram tratados com extrações de pré-molares e 43 sem extrações. A média de duração do tratamento foi de 29 meses. O tempo médio de controle pós-tratamento foi de 11 anos. Os resultados deste estudo sugeriram que o padrão vertical prétratamento não é predictivo da quantidade de alterações oclusais póstratamento. A ausência de diferenças estatisticamente significantes nas 
alterações pós-tratamento relacionadas ao padrão vertical difere do relatado na literatura. Autores como KILLIARIDIS et al. ${ }^{108}$, em 1993, ZAHER; BISHARA; JAKOBSEN ${ }^{220}$, em 1994 e RICKETTS ${ }^{171}$, em 1960, advogaram que o padrão de crescimento vertical geralmente exibe uma força muscular mandibular mais enfraquecida e menor capacidade de adaptação à expansão dos arcos durante o tratamento. Pode-se esperar, portanto, que as maiores alterações oclusais ocorram em pacientes dolicofaciais; nos pacientes braquifaciais, é comum a recidiva da sobremordida profunda.

Também neste ano, CARVALHO ${ }^{41}$ avaliou cefalometricamente a influência do padrão de crescimento facial na correção da má oclusão de Classe II, $1^{\text {a }}$ divisão, realizada com aparelho fixo da técnica de Arco de Canto Simplificada, ancoragem extrabucal cervical e extração dos quatro primeiros pré-molares. A amostra foi composta por 30 pacientes com padrão de crescimento equilibrado e 30 com padrão vertical. Verificou-se que o aumento das dimensões verticais da face ocorreu de modo semelhante entre os dois grupos. Apenas a proporção entre as alturas faciais anteriores denotou um comportamento mais favorável ao crescimento vertical. O comportamento vertical dos primeiros molares superiores e inferiores demonstrou um aumento similar em suas alturas para ambos os grupos. No padrão horizontal, ocorreu uma mesialização de corpo dos primeiros molares superiores, enquanto o padrão vertical apresentou a restrição deste deslocamento para mesial.

Num estudo cefalométrico prospectivo, REDDY et al. ${ }^{166}$, em 2000, avaliaram o modo e a magnitude de correção da Classe II por meio da mecânica de Begg sem extrações em pacientes dos 9 aos 12 anos de idade. 
Todos os pacientes da amostra apresentavam um padrão facial braqui ou mesodivergente. O período médio de tratamento foi de 9 meses. Dentre as alterações observadas ao final do estudo, a proporção entre a altura facial posterior e a anterior aumentou significantemente (1,17 vezes), demonstrando que houve um controle vertical bem efetuado e que contribuiu para a correção da Classe II.

A ancoragem extrabucal é amplamente utilizada para modificar a relação sagital entre as bases ósseas em pacientes em crescimento. Entretanto, ela também tem influência sobre o crescimento vertical. $O$ objetivo do estudo retrospectivo de KIM; MUHL ${ }^{109}$, publicado em 2001, foi avaliar as alterações mandibulares em 30 pacientes com Classe II tratados com ancoragem extrabucal cervical associada ao aparelho fixo e compará-las com as alterações ocorridas em 26 jovens não tratados ortodonticamente. Durante o tratamento, observou-se que a mandíbula sofreu uma suave rotação $\left(0,25^{\circ}\right)$ no grupo tratado em comparação ao grupo controle $\left(-1,7^{\circ}\right)$. No período de contenção, observou-se que o padrão de crescimento dos pacientes foi retomado. Não houve correlação entre as alterações nas alturas dentoalveolares superior e inferior e a rotação mandibular, sugerindo que tais alterações não constituem o maior determinante da rotação mandibular.

Os efeitos da ancoragem extrabucal cervical associada ao aparelho fixo em pacientes na fase de crescimento, ou seja, dos 7,5 aos 13,5 anos de idade também foram alvo do estudo de SCHIAVON GANDINI et al. ${ }^{181}$, em 2001. Assim, 45 pacientes tratados com esta abordagem terapêutica foram comparados com 30 jovens não submetidos a tratamento ortodôntico. A ancoragem extrabucal cervical foi utilizada até que se obtivesse a relação 
molar de Classe I. Os resultados demonstraram que a má oclusão foi provavelmente corrigida pela manutenção dos molares superiores em posição durante o processo de crescimento. $\mathrm{O}$ desenvolvimento vertical dos molares superiores não diferiu entre os tipos faciais.

Finalmente, em 2001, DARENDELILER; TANER-SARISOY ${ }^{58}$, utilizando a mesma amostra da pesquisa publicada em 1999, avaliaram os efeitos dos padrões de crescimento (meso e hiperdivergentes) e dos tipos de tratamento (com e sem ancoragem extrabucal) sobre as estruturas dentoalveolares. Como resultados, obtiveram uma diminuição da sobremordida no grupo mesodivergente estatisticamente significante quando comparada ao aumento da mesma no grupo hiperdivergente. A extrusão dos molares inferiores também foi significante, sendo maior no grupo hiperdivergente. Concluíram que a extração dos pré-molares e o uso da ancoragem extrabucal não alteram significantemente a sobressaliência, o ângulo do plano oclusal, as alturas dentoalveolares ântero-superior e inferior, a altura dentoalveolar póstero-superior ou a inclinação dos incisivos superiores e inferiores. As únicas alterações significantes foram observadas na sobremordida, devido à mecânica de tratamento, e na altura dentoalveolar póstero-inferior, devido ao padrão de crescimento.

Face ao exposto, tornou-se clara a necessidade de se verificarem quais as alterações provocadas pelo tratamento ortodôntico com extração dos quatro primeiros pré-molares sobre as alturas faciais e suas proporções nas Classes I e II, $1^{\text {a }}$ divisão, bem como estudar quais mensurações apresentam correlações entre si. 


\section{5- O ESTUDO CEFALOMÉTRICO EM GRUPOS RACIAIS E ÉTNICOS}

Até a década de 50, os ortodontistas de várias nações utilizavam normas estabelecidas pelas análises cefalométricas realizadas nos Estados Unidos, pelo fato de haver o maior número de pesquisas realizadas naquela população, que era, em grande parte, descendente dos anglo-saxões. Porém, nessa época, o desenvolvimento de diferentes análises fez estes profissionais começarem a verificar que o diagnóstico, o resultado final e a estabilidade da correção ortodôntica eram dependentes das limitações impostas pelo tipo facial do paciente, que por sua vez, variava de acordo com o grupo racial ou étnico ao qual pertencia.

Em 1951, surgiram os primeiros trabalhos publicados sobre a análise cefalométrica em diferentes grupos étnicos. COTTON, TAKANO, WONG ${ }^{49}$ aplicaram a análise de DOWNS ${ }^{63}$ em americanos descendentes de negros, japoneses e chineses, respectivamente, todos apresentando oclusão normal. Os valores cefalométricos obtidos confirmaram as diferenças entre os grupos estudados demonstrando a importância de serem consideradas no tratamento ortodôntico. Comparando suas amostras com os leucodermas, COTTON verificou um maior ângulo de convexidade nos melanodermas, TAKANO observou que os xantodermas apresentavam maior protrusão dentária e maior ângulo do Eixo "Y", podendo indicar um menor comprimento ânteroposterior da face, ou um crescimento predominantemente vertical e WONG verificou um padrão facial de Classe II nos americanos descendentes de chineses. 
Com o intuito de se comparar o padrão dentoesquelético de melanodermas e leucodermas norte-americanos, ALTEMUS ${ }^{4}$ em 1960, estudou uma amostra de 80 jovens com idades entre 12 e 16 anos. As telerradiografias foram analisadas de acordo com os cefalogramas de Downs e Sassouni. O autor verificou um maior tamanho absoluto da cabeça e da face dos melanodermas em relação aos leucodermas de mesma idade, além de haver ainda uma maior protrusão dentária e maior altura facial ântero-inferior. Portanto, os valores médios para um determinado grupo não devem ser aplicados em outro grupo sem que haja adaptações.

GRESHAM $^{80}$, em 1963, comparou os componentes dentoesqueléticos de crianças leucodermas, com oclusão normal, originárias da Nova Zelândia e dos Estados Unidos da América. Os resultados revelaram que o ângulo ANB foi significantemente maior na amostra norte-americana, ao passo que o ângulo interincisivos foi maior no grupo da Nova Zelândia.

Com relação aos xantodermas japoneses, MIURA; INOUE; SUZUKI ${ }^{140}$ destacaram-se em dois estudos, um de 1963 e outro de 1965, nos quais estabeleceram valores cefalométricos normativos para a idade média de 10 anos e 9 meses. Por meio da comparação com os valores propostos por Steiner, observaram que os japoneses apresentavam tendência a uma mandíbula retroposicionada e a uma protrusão e vestibuloversão dos incisivos superiores e inferiores.

Analisando 38 telerradiografias pertencentes a japonesas adultas, com oclusão normal, perfis faciais aceitáveis e faixa etária entre os 18 e 25 anos de 
idade, ITO; SUEMATSU ${ }^{98}$, em 1967, verificaram que o local de maior variação entre os indivíduos é a face inferior, principalmente na região do mento.

Com o intuito de se detectar um possível dimorfismo entre os gêneros, YAMAUCHI et al. ${ }^{218}$, em 1967, analisaram os tecidos duros e moles de 30 estudantes japoneses do gênero masculino, com oclusão normal e idade entre 23 e 26 anos. As medidas obtidas foram comparadas com as observadas por ITO; SUEMATSU ${ }^{98}$ no gênero feminino. Os autores verificaram uma maior espessura do lábio superior no gênero masculino.

Quando comparados aos leucodermas norte-americanos, os melanodermas norte-americanos, com oclusão normal, caracterizam-se por um ângulo FMA maior, pelo posicionamento mais anterior da maxila e pela biprotrusão dentária, segundo DRUMMOND ${ }^{65}$, em 1968.

Neste mesmo ano, UESATO ${ }^{204}$ preocupou-se em estabelecer alguns parâmetros para o tratamento ortodôntico em pacientes norte-americanos descendentes de japoneses, pois acreditava que havia diferenças marcantes entre estes, os japoneses e os caucasianos. Para isso, realizou uma comparação entre as amostras com oclusão normal, pertencentes a diferentes autores. Assim, utilizou a amostra de Downs e Steiner para os caucasianos, a de MIURA; INOUE; SUZUKI ${ }^{140}$ para os japoneses e a de TAKANO para os norte-americanos descendentes de japoneses. Verificou-se uma maior tendência dos japoneses e dos norte-americanos descendentes de japoneses para um padrão de Classe II. Em relação aos incisivos, os japoneses apresentam maior biprotrusão dentária que os caucasianos, enquanto os norte- 
americanos descendentes de japoneses apresentam o posicionamento dos incisivos bastante semelhante aos caucasianos. Como os japoneses norteamericanos sofrem influência do padrão de beleza dos caucasianos e não dos japoneses, UESATO ${ }^{204}$ sugere que o ortodontista deve buscar um perfil facial cuja linha do perfil deve estar entre a E de Ricketts e a $S$ de Steiner.

Utilizando a análise de Steiner, SHISHIKURA ${ }^{187}$, em 1969, estabeleceu valores normais para os xantodermas japoneses por meio de uma amostra composta por 96 japoneses adultos, com oclusão normal e 36 estudantes de Odontologia, com perfis agradáveis.

$\mathrm{CHAN}^{43}$, em 1972, investigou uma amostra de 30 chineses (cantonenses) do gênero masculino, com idade entre 18 e 33 anos, que apresentavam oclusão excelente e perfis harmoniosos ou aceitáveis. Verificou uma mandíbula retrognática e uma biprotrusão dentária quando comparados aos leucodermas. Os chineses apresentaram também um ângulo facial menor, um maior ângulo do plano mandibular e um Eixo "Y" aumentado, além dos lábios mais protruídos e um perfil mais convexo que os leucodermas.

Com o intuito de auxiliar o diagnóstico e o plano de tratamento, $\mathrm{YEN}^{219}$, em 1973, estabeleceu o padrão facial de chineses, fornecendo informações a respeito das características raciais. Sua amostra foi composta por 50 jovens do gênero masculino, com idade média de 11,8 anos, com oclusão normal e equilíbrio da musculatura facial. Observou um achatamento da face superior, uma retrusão do mento e uma protrusão dos incisivos superiores e inferiores. 
Para verificarem a estética facial e determinarem as medidas para o triângulo de TWEED $^{203}$, na tentativa de se correlacionar os lábios e a posição dos incisivos, IWASAWA; MORO; NAKAMURA ${ }^{99}$, em 1977, realizaram um estudo utilizando o ângulo $\mathrm{Z}$, proposto por MERRIFIELD ${ }^{139}$. Analisaram 118 japoneses de ambos os gêneros, com idades entre 19 e 24 anos e compararam os valores obtidos com os propostos para leucodermas. Assim, o ângulo $\mathrm{Z}$ apresentou-se significantemente menor nos leucodermas, sendo que o lábio superior foi o que predominantemente tocou essa linha. Nos japoneses, o mento é mais retruído e os dentes anteriores são mais protruídos que nos leucodermas. Os valores médios para as medidas FMA, IMPA e FMIA foram, respectivamente, $27,28^{\circ}, 95,50^{\circ}$ e $57,22^{\circ}$.

$\mathrm{JACOBSON}^{100}$, em 1978, realizou um estudo em uma amostra de melanodermas sul-africanos, sendo 27 do gênero masculino e 28 do feminino, com oclusão excelente, comparando os valores aos de leucodermas com oclusões também excelentes. Observou-se que nos melanodermas, a maxila se posicionou mais anteriormente em relação à base do crânio, o ângulo ANB apresentou-se aumentado e os incisivos inferiores com maior inclinação vestibular. Entretanto, a inclinação dos incisivos superiores foi bastante semelhante à dos leucodermas.

Comparando-se cefalometricamente 35 japoneses e tailandeses, com oclusão normal, adultos, do gênero masculino e perfis harmoniosos, LIN ${ }^{118}$, em 1978, utilizou as análises de Downs e Tweed. Verificou que o plano mandibular (PoOr.GoMe) de Downs foi menor nos tailandeses do que nos japoneses e uma maior inclinação vestibular dos incisivos inferiores nos tailandeses. 
Dois anos mais tarde, num estudo longitudinal, MASAKI ${ }^{130}$ avaliou as diferenças das estruturas craniofaciais entre os xantodermas japoneses e os leucodermas norte-americanos. Todos os integrantes da amostra possuíam oclusão normal e idades entre os 7 e 15 anos. O comprimento da base craniana e da altura facial anterior foram significantemente maiores nos japoneses de ambos os gêneros quando comparados ao grupo dos norteamericanos. Os ângulos Z e SN.Pocl também foram maiores nos japoneses. Estes apresentaram um padrão facial divergente, com rotação horária da mandíbula, associada a uma maxila menor.

Em 1996, para compararem adultos xantodermas de origem japonesa e leucodermas americanos de origem européia, MYIAJIMA et al. ${ }^{142}$ observaram que a amostra masculina xantoderma apresentou um maior comportamento vertical, comprovado pelo ângulo maior do eixo facial (BaN.PTMGn), além de um menor comprimento efetivo da maxila e da mandíbula. Já no gênero feminino, a altura facial anterior foi maior, com o ângulo FMA aumentado e uma tendência vertical. Todas as medidas referentes ao perfil (ângulo nasolabial, inclinação do lábio superior, Is-linha $\mathrm{E}$ e Ii-linha E) demonstraram maior protrusão nos xantodermas de ambos os gêneros.

No Brasil, o estudo dos vários grupos étnicos assume importância fundamental, por ser um país de grande variação de raças, etnias e miscigenação entre elas. As comparações entre as medidas cefalométricas de melanodermas e leucodermas abrangem várias pesquisas, dentre elas a de 
BERTOZ; MARTINS ${ }^{15}$, a de HENRIQUES \& FREITAS $^{87}$, a de MEDEIROS; HENRIQUES; FREITAS ${ }^{136}$ e a de MORAES; FREITAS; HENRIQUES ${ }^{144}$.

Com relação à comparação entre os leucodermas brasileiros e norteamericanos, FREITAS ${ }^{71}$, em 1978, avaliou as análises do perfil facial preconizadas por Steiner, Burstone, Merrifield, Ricketts e Holdaway, a fim de verificar qual era a que mais se coadunaria com o perfil do brasileiro. Como resultados, o autor observou que o perfil facial do brasileiro do gênero masculino é mais convexo que o dos norte-americanos e que as análises de Steiner e de Burstone foram as que melhor se enquadraram ao perfil mole de leucodermas brasileiros. Trabalhos brasileiros semelhantes foram realizados por MARTINS ${ }^{128}$, CERCI $^{42}$, MATOS $^{131}$, REZENDE; TELLES ${ }^{167}$, ALMEIDA $^{3}$ e MARTINS; VIGORITO ${ }^{129}$.

Em relação aos xantodermas brasileiros, sejam eles descendentes de japoneses ou chineses, são escassos os estudos cefalométricos realizados.

Efetuando um estudo comparativo do tipo de oclusão dentária entre os brasileiros descendentes de japoneses originários da ilha de Okinawa e originários das demais ilhas, SAKIMA ${ }^{173}$, em 1976 examinaram 198 nisseis japoneses (grupo I) e 198 nisseis okinawanos (grupo II), com idade variando de 10 a 41 anos. O autor selecionou os indivíduos segundo a classificação de Angle e, posteriormente, pelas radiografias cefalométricas em norma lateral. Concluiu ser impossível classificar o indivíduo somente pelo tipo de oclusão, não sendo possível também a distinção entre japoneses e okinawanos por meio do prognatismo mandibular. 
Com o objetivo de se determinar a linha "I" para xantodermas nipobrasileiros, RADDI; HENRIQUES; MARTINS ${ }^{165}$, em 1989, utilizaram uma amostra de 26 telerradiografias cefalométricas em norma lateral de filhos e netos de japoneses, de ambos os gêneros, com oclusão normal e faixa etária de 12 a 18 anos e 6 meses, que não haviam se submetido a tratamento ortodôntico. Os valores obtidos foram comparados aos efetuados por INTERLANDI $^{95}$, em leucodermas brasileiros e MEDEIROS; HENRIQUES; FREITAS $^{136}$, em melanodermas brasileiros. Concluíram que os xantodermas brasileiros apresentaram o valor médio da linha "I" de $-4,40 \mathrm{~mm}$, variando de $-8,5 \mathrm{a}-0,5 \mathrm{~mm}$. Com base na comparação entre as três raças, aconselharam a utilização de uma medida própria para cada grupo racial.

Em 1998, MARTINS et al. ${ }^{127}$ publicaram o "Atlas de Crescimento Craniofacial", que é resultado de um brilhante estudo longitudinal de 75 jovens brasileiros leucodermas ( 37 do gênero masculino e 38 do feminino) dos 6 aos 18 anos de idade. A amostra era descendente de mediterrâneos: portugueses, espanhóis ou italianos, sem mutilações nos arcos dentários e que nunca haviam sido submetidos ao tratamento ortodôntico. Os dados obtidos foram os relacionados às análises cefalométricas de Downs, Steiner, Tweed, Ricketts e Mcnamara e fornecem ao ortodontista um inestimável auxílio durante o diagnóstico, plano de tratamento e prognóstico em pacientes de mesma origem da pesquisa.

Neste mesmo ano, TAKAHASHI ${ }^{196}$, percebendo a necessidade de se determinar os valores médios de normalidade das grandezas cefalométricas esqueléticas, dentárias e tegumentares de nipo-brasileiros, com oclusão normal, estudou o padrão cefalométrico FOB-USP para este grupo étnico, 
utilizando 41 telerradiografias cefalométricas em norma lateral de jovens com idades de 12 a 18 anos e 6 meses. Os valores cefalométricos estudados, por apresentarem características próprias e específicas desta população, mais uma vez demonstraram que tais diferenças não podem ser esquecidas durante o diagnóstico e o plano de tratamento.

A importância de se estabelecer valores normativos para as diversas raças e etnias já se encontra embutida no pensamento dos ortodontistas da atualidade, sendo alvo de inúmeras pesquisas cefalométricas. Entretanto, o estudo das alterações esqueléticas, dentárias e as relativas ao tecido mole advindas do tratamento ortodôntico em xantodermas encontra-se bastante deficiente. Hoje, os brasileiros descendentes de japoneses compõem uma parcela considerável da população, particularmente nos estados de São Paulo e Paraná. Além disso, a experiência clínica nos revela que um elevado número de pacientes xantodermas procura por tratamento ortodôntico devido às preocupações estéticas, causadas não somente pela má oclusão de Classe III, mas também pelo acentuado número de apinhamentos dentários e biprotrusões. Apesar disto, não foi encontrado nenhum estudo cefalométrico brasileiro sobre as alterações incitadas pelo tratamento ortodôntico em nipobrasileiros, ficando nítida a necessidade de se verificarem quais as alterações provocadas pelo tratamento ortodôntico com extração dos quatro primeiros pré-molares sobre as alturas faciais e suas proporções nesse grupo étnico. 


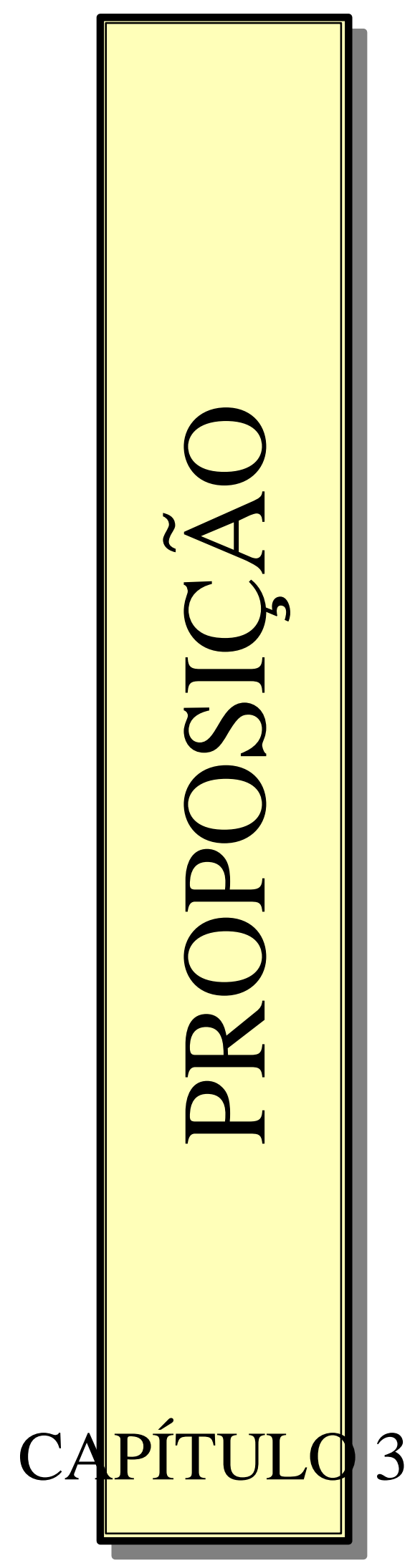




\section{PROPOSIÇÃO}

O objetivo desta pesquisa foi estudar, cefalometricamente, as alturas faciais anterior (AFA) e posterior (AFP) em pacientes brasileiros, xantodermas, descendentes de japoneses, de ambos os gêneros, com más oclusões de Classe I e Classe II, $1^{\text {a }}$ divisão de Angle tratados com e sem extração dos quatro primeiros pré-molares, com o intuito de observar se, ao final do tratamento ortodôntico:

3.1- Existem diferenças estatisticamente significantes nas alterações das alturas faciais anterior e posterior entre os casos tratados com e sem extração dos primeiros pré-molares;

3.2- Os ângulos FMA e SN.GoGn aumentam, diminuem ou se mantêm constantes;

3.3- O Índice de Horn (PHF/AFH) aumenta ou diminui;

3.4- As dimensões AFA e AFP e a proporção AFP/AFA aumentam, diminuem ou se mantêm constantes;

3.5- Há alterações nas proporções faciais anteriores (AFAI/AFAS, AFAI/AFA e AFAI/AFAS);

3.6- Existe dimorfismo entre os gêneros nas alterações das alturas faciais anterior e posterior. 


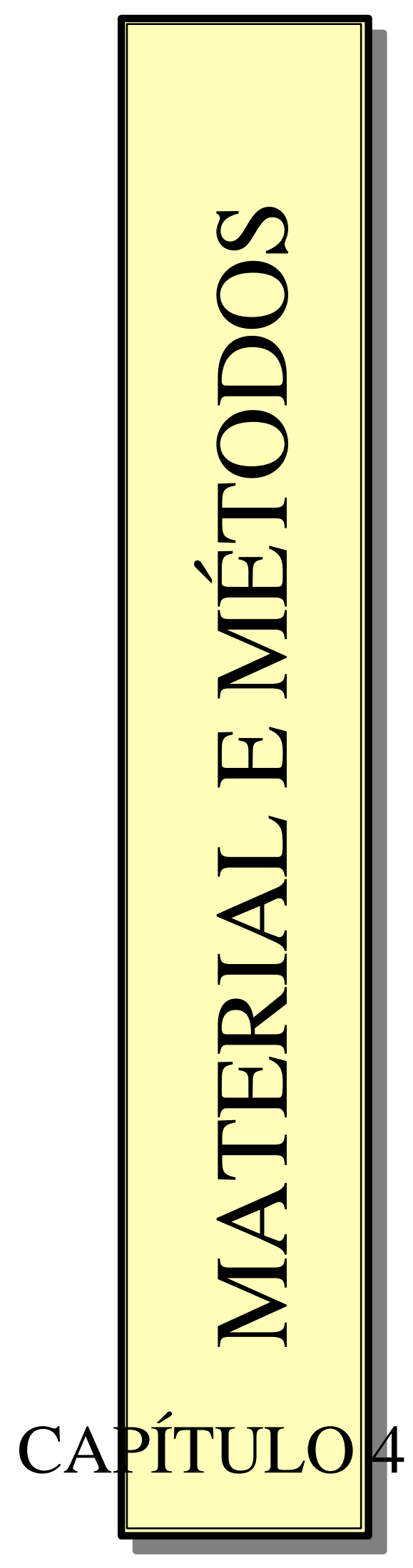




\section{MATERIAL E MÉTODOS}

\section{1- MATERIAL}

A amostra constituiu-se de 118 telerradiografias em norma lateral, obtidas de 59 pacientes adolescentes, nipo-brasileiros, tomadas antes e imediatamente após o tratamento ortodôntico. Atualmente, a miscigenação racial no Brasil é bastante ampla, sendo muito mais comum a existência de mestiços do que de descendentes puros, mesmo em xantodermas. Por esse motivo, uma das dificuldades encontradas durante a coleta desta amostra foi a obtenção de um número suficiente de pacientes nipo-brasileiros que tivessem sido tratados apenas no curso de Pós-graduação em Ortodontia da FOB-USP. Assim, também foram selecionados pacientes de uma clínica particular localizada na cidade de Bauru e de outra na cidade de São Paulo.

Para melhor padronização dos grupos, os seguintes critérios foram respeitados:

1) Jovens filhos ou netos de japoneses;

2) Faixa etária dos 10 aos 18 anos de idade, de ambos os gêneros;

3) Presença de todos os dentes permanentes superiores e inferiores, até os primeiros molares permanentes e sem mutilações no arco dentário;

4) Presença de má oclusão de Classe I ou Classe II, $1^{\text {a }}$ divisão de Angle, constatadas por meio das fichas clínicas e de modelos de estudo;

5) Todos tratados com a Técnica do Arco de Canto Simplificada; ${ }^{72}$

6) Padrão de crescimento equilibrado. 


\subsection{1- Critério para seleção da amostra segundo o padrão de crescimento}

Para uma maior homogeneidade da amostra, selecionaram-se apenas pacientes com más oclusões de Classe I e de Classe II, $1^{\text {a }}$ divisão de Angle com padrão de crescimento equilibrado. A seleção da amostra conforme o padrão de crescimento obedeceu aos valores normais de FMA ou SN.GoGn propostos por TAKAHASHI ${ }^{196}$ para nipo-brasileiros, com valores de FMA compreendidos entre 23,4 e 34,4 graus para o gênero feminino $(28,9 \pm 5,5) \mathrm{e}$ entre 22,4 e 32,0 graus para o masculino $(27,2 \pm 4,8)$ e SN.GoGn compreendidos entre os 27,3 e 39,1 graus para o gênero feminino $(33,2 \pm 5,9)$ e 26,4 e 35,2 graus para o masculino $(30,8 \pm 4,4)$.

Sendo assim, distribuiu-se a amostra como ilustrado na Tabela 4.1.

TABELA 4.1 - Características da amostra empregada

\begin{tabular}{|c|c|l|}
\hline GRUPO & $\begin{array}{c}\text { NÚMERO } \\
\text { (N) }\end{array}$ & \multicolumn{1}{|c|}{ CARACTERÍSTICA } \\
\hline I & 15 & Classe I com extração dos 4 primeiros pré-molares \\
\hline II & 15 & Classe I sem extrações \\
\hline III & 14 & $\begin{array}{l}\text { Classe II, 1 1ª divisão com extração dos } 4 \text { primeiros pré- } \\
\text { molares }\end{array}$ \\
\hline IV & 15 & Classe II, 1ª divisão sem extrações \\
\hline
\end{tabular}


Para a realização dos tratamentos ortodônticos, utilizaram-se acessórios da técnica do Arco de Canto Simplificada com ranhura .022"x.028" (0,558 x $0,711 \mathrm{~mm}$ ) e fios twist-flex redondos e de aço inoxidável redondos de diâmetros de .016" $(0,406 \mathrm{~mm})$ ao .020" $(0,508 \mathrm{~mm})$ para o nivelamento, assim como fios retangulares .019 ” $.025 "(0,482$ x $0,635 \mathrm{~mm})$ e .021 ” .025 " $(0,533 \times 0,635 \mathrm{~mm})$ para a fase final de nivelamento, retração anterior (para os casos tratados com extração) e aplicação dos torques.

Nos Grupos I e II, ou seja, os que apresentavam más oclusões de Classe I tratadas com e sem extração dos quatro primeiros pré-molares, respectivamente, a relação molar foi mantida por meio da ancoragem extrabucal cervical (400 a 600 gramas de força), e da placa lábio-ativa e dos elásticos de Classe III, quando necessários, utilizados durante 10 horas por dia.

Nos Grupos III e IV (más oclusões de Classe II tratadas com e sem extração dos quatro primeiros pré-molares, respectivamente), utilizou-se a ancoragem extrabucal cervical (400 a 600 gramas de força) durante 18 horas por dia até a obtenção da relação molar de Classe I; a partir daí, o uso do aparelho passava a ser de 10 horas ao dia.

O tempo médio de tratamento foi de 2,45 anos para o Grupo I, 2,01 anos para o Grupo II, 2,93 anos para o Grupo III e 2,58 anos para o Grupo IV. Após o período de tratamento ativo, utilizou-se como contenção no arco superior a placa removível de Hawley e a barra 3x3 no arco inferior. 


\section{2- MÉTODOS}

\subsection{1- A OBTENÇÃO DAS TELERRADIOGRAFIAS EM NORMA LATERAL}

As telerradiografias pré e pós-tratamento dos pacientes da amostra foram obtidas em norma lateral, com os jovens ocluindo em posição de máxima intercuspidação habitual, com os lábios em repouso e obedecendo-se aos critérios convencionalmente aceitos de padronização para a tomada radiográfica e para o processamento dos filmes radiográficos.

Pelo fato das telerradiografias terem sido obtidas em diferentes centros de documentação, para uma correta análise e comparação das medidas obtidas, houve a necessidade de se calcular o fator de magnificação para cada um dos centros radiográficos, obtendo-se quatro valores para os mesmos: $6 \%$, $7,3 \%, 7,9 \%$ e 9,8\%. Tais fatores foram adicionados às informações solicitadas pelo programa Dentofacial Planner 7.02 Plus $^{a}$ que, automaticamente converteu os valores ampliados para os valores reais.

\footnotetext{
${ }^{a}$ Dentofacial Software Inc.- 100 Simcoe Street, Suite 303, Toronto, Ontário, Canadá.
} 


\subsubsection{1- Cálculo do fator de magnificação}

O fator de magnificação corresponde à porcentagem de ampliação da imagem radiográfica em relação ao tamanho real das estruturas do complexo craniofacial. Para seu cálculo, é preciso primeiramente medir a distância de uma oliva metálica a outra (A). Em seguida, mantendo-se a mesma medida A entre as olivas, obtém-se uma radiografia PA (póstero-anterior) na qual apareça a imagem radiográfica apenas das olivas metálicas (B). Assim, o fator de magnificação $(\mathrm{X})$ é obtido por meio da seguinte fórmula matemática:

$$
X=\frac{B-A}{A} \times 100
$$

Em que:

$\mathrm{X}=$ Fator de magnificação

$\mathrm{A}=$ Distância de uma oliva metálica a outra

$\mathrm{B}=$ Distância de uma oliva metálica a outra na imagem radiográfica

Para se ilustrar esse cálculo, apresenta-se, a seguir, um exemplo:

Distância de uma oliva metálica a outra (A): $15.1 \mathrm{~cm}$

Distância de uma oliva metálica a outra na imagem radiográfica (B): $16.3 \mathrm{~cm}$

Cálculo para o fator de magnificação (x):

$$
\frac{\mathrm{B}-\mathrm{A}}{\mathrm{A}} \times 100=\frac{16.3-15.1}{15.1} \times 100=\mathbf{7 . 9 \%}
$$


Além disso, há uma maneira de se verificar se o cálculo do fator de magnificação está correto. Deve-se obter a distância do ponto focal ao plano sagital mediano (C) e a distância do ponto focal ao filme (D). Em seguida, aplica-se a seguinte fórmula:

$$
\frac{\mathrm{A}}{\mathrm{B}}=\frac{\mathrm{C}}{\mathrm{D}}
$$

O valor de B deverá se aproximar ao máximo do valor medido na radiografia PA. Se isso ocorrer, confirma-se que o fator de magnificação está correto. Assim, por exemplo:

Distância do ponto focal ao plano sagital mediano (C): $151.2 \mathrm{~cm}$

Distância do ponto focal ao filme (D): $166.5 \mathrm{~cm}$

$$
\frac{\mathrm{A}}{\mathrm{B}}=\frac{\mathrm{C}}{\mathrm{D}} \quad \frac{15.1}{\mathrm{~B}}=\frac{151.2}{166.5} \quad \mathrm{~B}=16.6
$$

Como o valor encontrado na radiografia PA para B foi de $16,3 \mathrm{~cm}$, demonstra-se que o fator de magnificação foi corretamente calculado. 


\subsection{2- A ELABORAÇÃO DOS CEFALOGRAMAS}

Os traçados foram realizados em sala escurecida para melhor visualização das estruturas anatômicas de interesse. Sobre cada telerradiografia, adaptou-se uma folha de papel de acetato transparente "Ultraphan", de tamanho 17,5 cm x 17,5 cm e espessura de 0,07 mm, fixada por meio de fita adesiva. Para auxiliar a perfeita determinação das estruturas anatômicas, colocou-se uma máscara de cartolina preta sobre cada radiografia, de modo a eliminar ao máximo a luminosidade lateral proveniente do negatoscópio. Com lapiseira e grafite preto $\mathrm{H}$ de $0,3 \mathrm{~mm}$, uma mesma operadora traçou os cefalogramas sobre um negatoscópio, desenhando primeiramente as estruturas anatômicas de interesse e, em seguida, demarcou os pontos cefalométricos.

Em seguida, os pontos cefalométricos foram digitalizados por meio de uma mesa digitalizadora Numonics Accugrid $X N T^{a}$, conectada a um microcomputador Pentium II - $166 M M X^{b}$ e para a mensuração das grandezas cefalométricas, utilizou-se o programa Dentofacial Planner 7.02 Plus.

\footnotetext{
${ }^{a}$ Numonics Corporation- 101 Commerce Drive, Montgomerryville, PA 18963

${ }^{b}$ Intel Corporation - 2200 Mission College Blvd., Santa Clara, CA, E.U.A..
} 


\subsection{3- A DELIMITAÇÃO DO DESENHO ANATÔMICO}

O traçado cefalométrico incluiu as seguintes estruturas anatômicas:

TABELA 4.2 - Estruturas anatômicas incluídas no traçado cefalométrico

\section{ESTRUTURAS ANATÔMICAS}

- a sela túrcica;

- o corpo do esfenóide;

- o meato auditivo externo;

- a fissura pterigomaxilar;

- o limite póstero-inferior das cavidades orbitárias;

- os contornos da maxila e da mandíbula;

- os incisivos centrais superiores e inferiores;

- os primeiros molares superiores e inferiores

- o contorno anterior do osso frontal e dos ossos nasais;

- o perfil mole, estendendo-se desde a região acima da glabela até o contorno inicial do pescoço. 


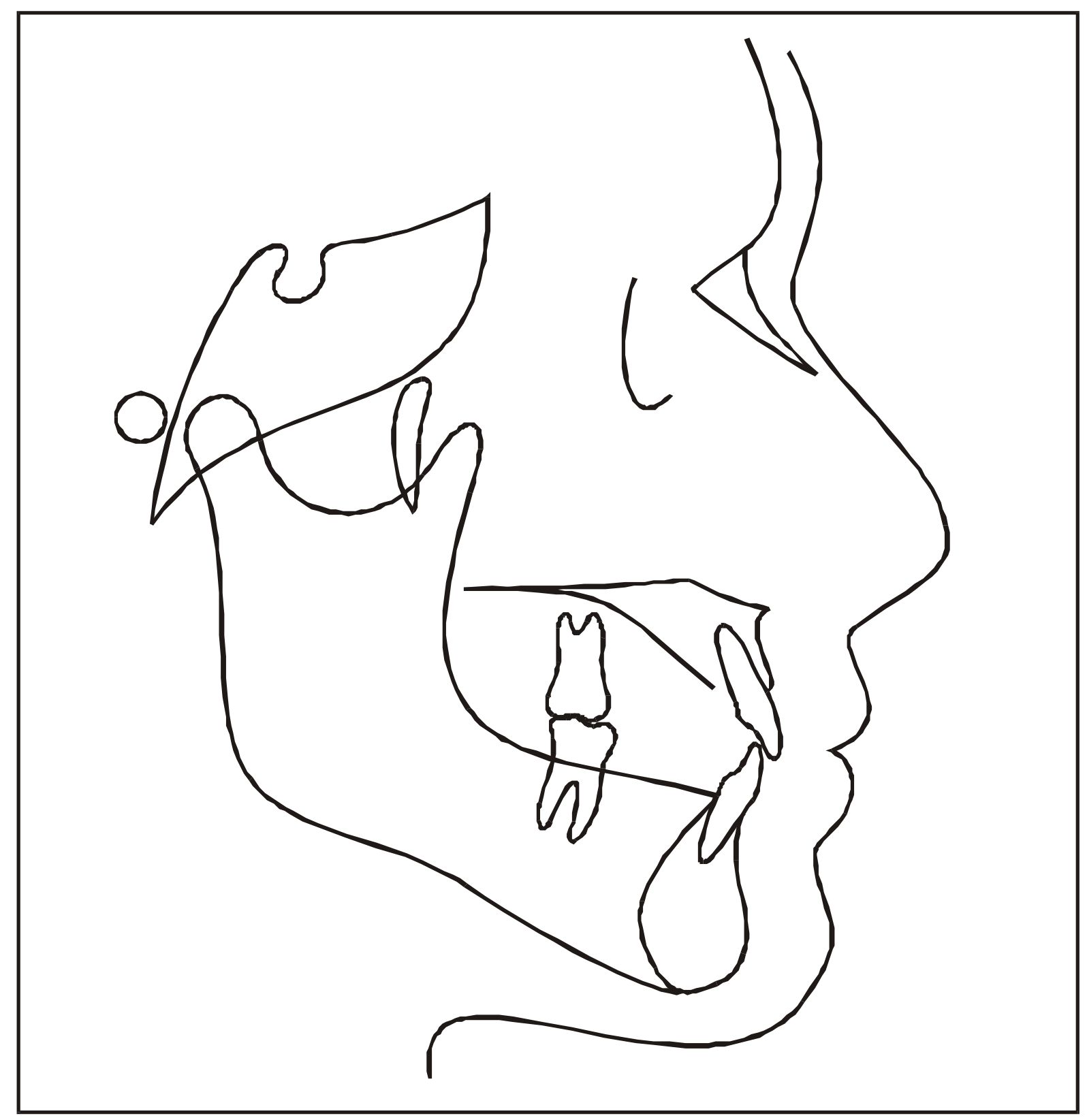

FIGURA 4.1 - Delimitação do desenho anatômico 


\subsection{4- A DEMARCAÇÃO DOS PONTOS CEFALOMÉTRICOS}

Os seguintes pontos cefalométricos foram utilizados:

TABELA 4.3 - Descrição dos pontos cefalométricos utilizados

\begin{tabular}{|c|c|c|}
\hline Número & Abreviação & Definição \\
\hline 1 & $\mathrm{~N}$ & $\begin{array}{l}\text { NÁSIO- Intersecção da sutura internasal com a sutura } \\
\text { frontonasal. }\end{array}$ \\
\hline 2 & S & $\begin{array}{l}\text { SELA TÚRCICA- Centro da concavidade óssea da sela } \\
\text { túrcica. }\end{array}$ \\
\hline 3 & Or & $\begin{array}{l}\text { ORBITÁRIO- Ponto mais inferior da margem } \\
\text { infraorbitária. }\end{array}$ \\
\hline 4 & Po & PÓRIO- Ponto mais superior do meato auditivo externo. \\
\hline 5 & PTM & $\begin{array}{l}\text { FISSURA PTERIGOMAXILAR- Ponto mais póstero- } \\
\text { superior da fissura pterigomaxilar. }\end{array}$ \\
\hline 6 & $\mathrm{Ar}$ & $\begin{array}{l}\text { ARTICULAR- Intersecção da face inferior da base } \\
\text { craniana com o contorno distal dos côndilos mandibulares. }\end{array}$ \\
\hline 7 & ENA & $\begin{array}{l}\text { ESPINHA NASAL ANTERIOR- Ponto mais anterior do } \\
\text { palato duro; intersecção da parte ântero-superior da maxila } \\
\text { com o assoalho da fossa nasal. }\end{array}$ \\
\hline 8 & ENP & $\begin{array}{l}\text { ESPINHA NASAL POSTERIOR- Ponto mais posterior do } \\
\text { palato duro. }\end{array}$ \\
\hline 9 & A & $\begin{array}{l}\text { PONTO A- Ponto mais profundo da concavidade anterior } \\
\text { da maxila. }\end{array}$ \\
\hline 10 & B & $\begin{array}{l}\text { PONTO B- Ponto mais profundo da concavidade anterior } \\
\text { da mandíbula. }\end{array}$ \\
\hline 11 & $\mathrm{P}$ & POGÔNIO- Ponto mais proeminente do mento ósseo. \\
\hline 12 & Gn & $\begin{array}{l}\text { GNÁTIO- Ponto mais ântero-inferior do contorno do mento } \\
\text { ósseo. }\end{array}$ \\
\hline 13 & $\mathrm{Me}$ & MENTONIANO- Ponto mais inferior do contorno da \\
\hline
\end{tabular}




\begin{tabular}{|c|c|c|}
\hline & & sínfise mentoniana. \\
\hline 14 & Go & $\begin{array}{l}\text { GÔNIO- Ponto mais póstero-inferior do contorno do } \\
\text { ângulo goníaco. }\end{array}$ \\
\hline 15 & CMS & $\begin{array}{l}\text { CÚSPIDE DO MOLAR SUPERIOR- Ponto mais inferior } \\
\text { da cúspide mesial do primeiro molar superior. }\end{array}$ \\
\hline 16 & DMS & $\begin{array}{l}\text { DISTAL DO MOLAR SUPERIOR- Ponto mais posterior } \\
\text { da face distal do primeiro molar superior. }\end{array}$ \\
\hline 17 & CMI & $\begin{array}{l}\text { CÚSPIDE DO MOLAR INFERIOR- Ponto mais superior } \\
\text { da cúspide mesial do primeiro molar inferior. }\end{array}$ \\
\hline 18 & DMI & $\begin{array}{l}\text { DISTAL DO MOLAR INFERIOR- Ponto mais posterior da } \\
\text { face distal do primeiro molar inferior. }\end{array}$ \\
\hline
\end{tabular}

Os pontos apresentados seguem as demarcações e definições apresentadas por KROGMAN; SASSOUNI ${ }^{114}$ (1957), por MCNAMARA JÚNIOR $^{135}$ (1984) e RICKETTS ${ }^{172}$ (1961). 
Mateial eMéoodos

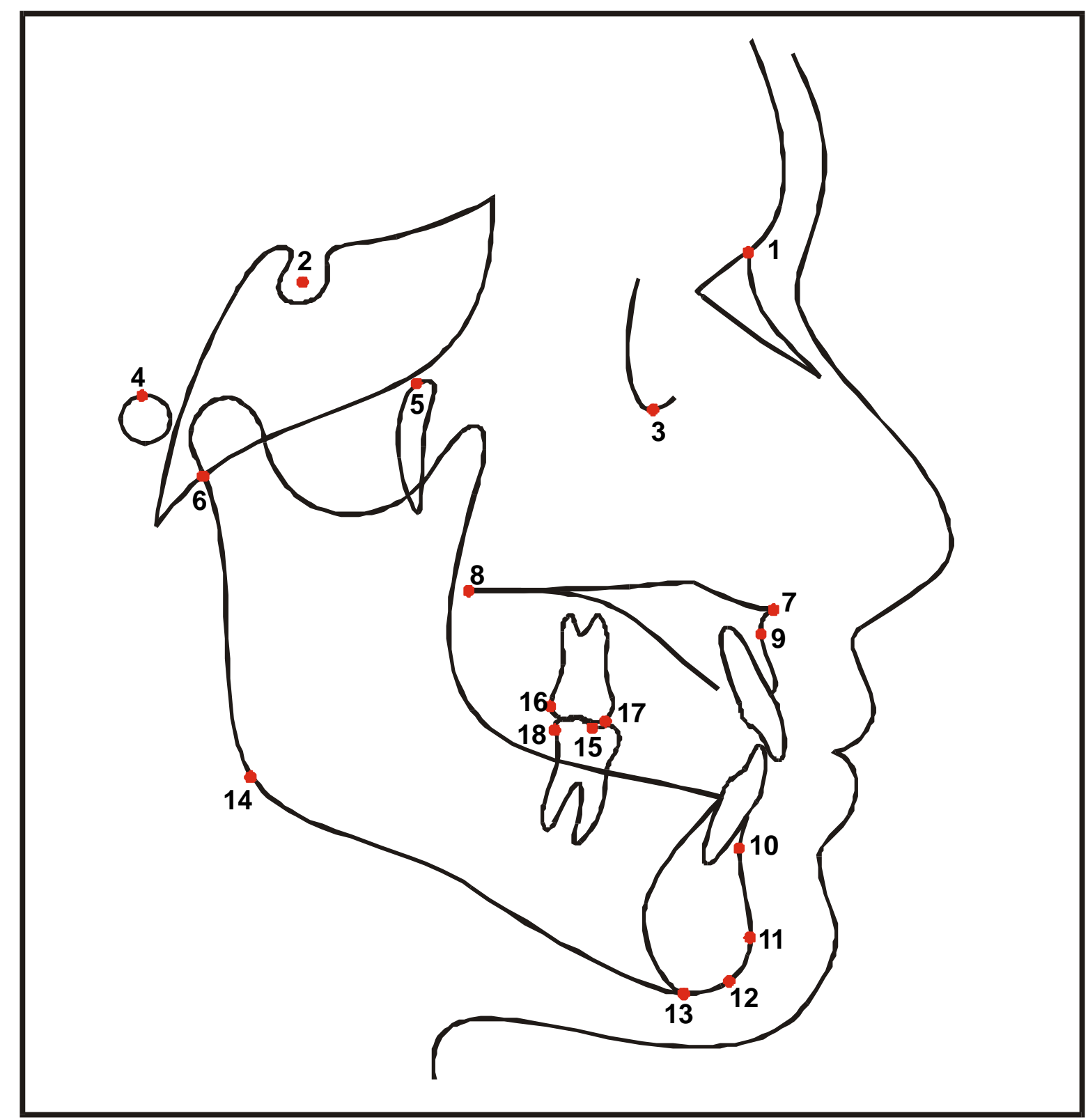

FIGURA 4.2 - Pontos cefalométricos utilizados 


\subsection{5- LINHAS E PLANOS DE REFERÊNCIA}

TABELA 4.4 - Descrição das linhas e planos utilizados

\section{Número Definição}

2 Plano de Francfort (Po-Or) - do pório ao orbitário

3 Plano palatino (ENA-ENP) - da espinha nasal anterior à espinha nasal posterior

4 Plano mandibular (Go-Me) - do gônio ao mentoniano

5 Plano mandibular (Go-Gn) - do gônio ao gnátio

6 Linha PTV - Linha perpendicular ao Plano de Francfort passando pelo ponto PTM 
92

Material eMéodos

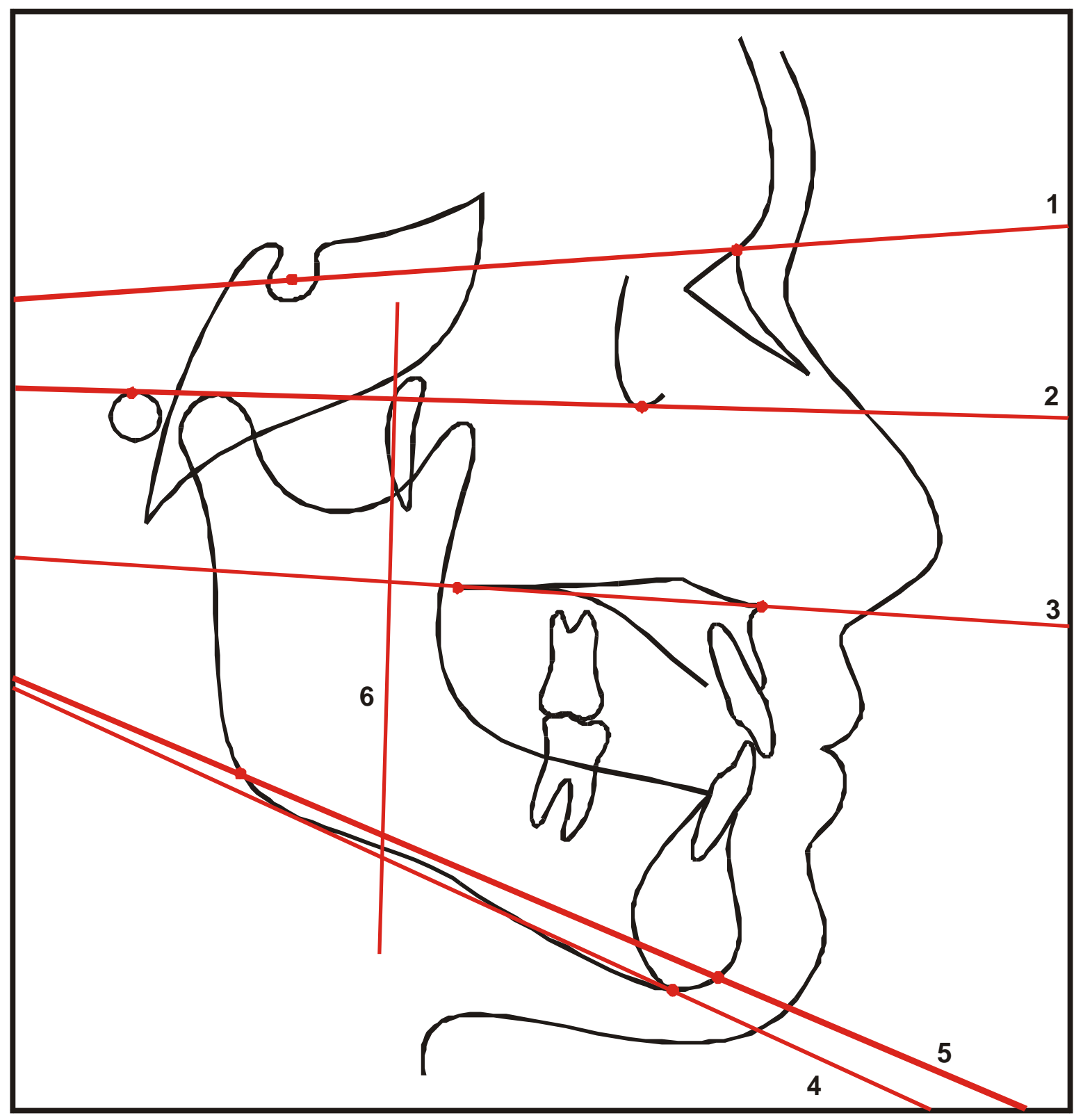

FIGURA 4.3 - Linhas e planos de referência utilizados 


\subsubsection{A OBTENÇÃO DAS MEDIDAS CEFALOMÉTRICAS} ANGULARES

TABELA 4.5 - Descrição das grandezas cefalométricas angulares

\begin{tabular}{ccl}
\hline Número & Abreviação & \multicolumn{1}{c}{ Descrição } \\
\hline 1 & FMA & Ângulo entre o plano de Francfort e o \\
& Plano Mandibular, que é um plano que \\
& tangencia a borda inferior da mandíbula, \\
& passando pelo ponto mentoniano, como \\
& & proposto por TWEED ${ }^{203}$. \\
& & Ângulo entre Sela-Násio e Gônio- \\
& SN.GoGn & Gnátio \\
\hline
\end{tabular}


Mateial eMéoodos

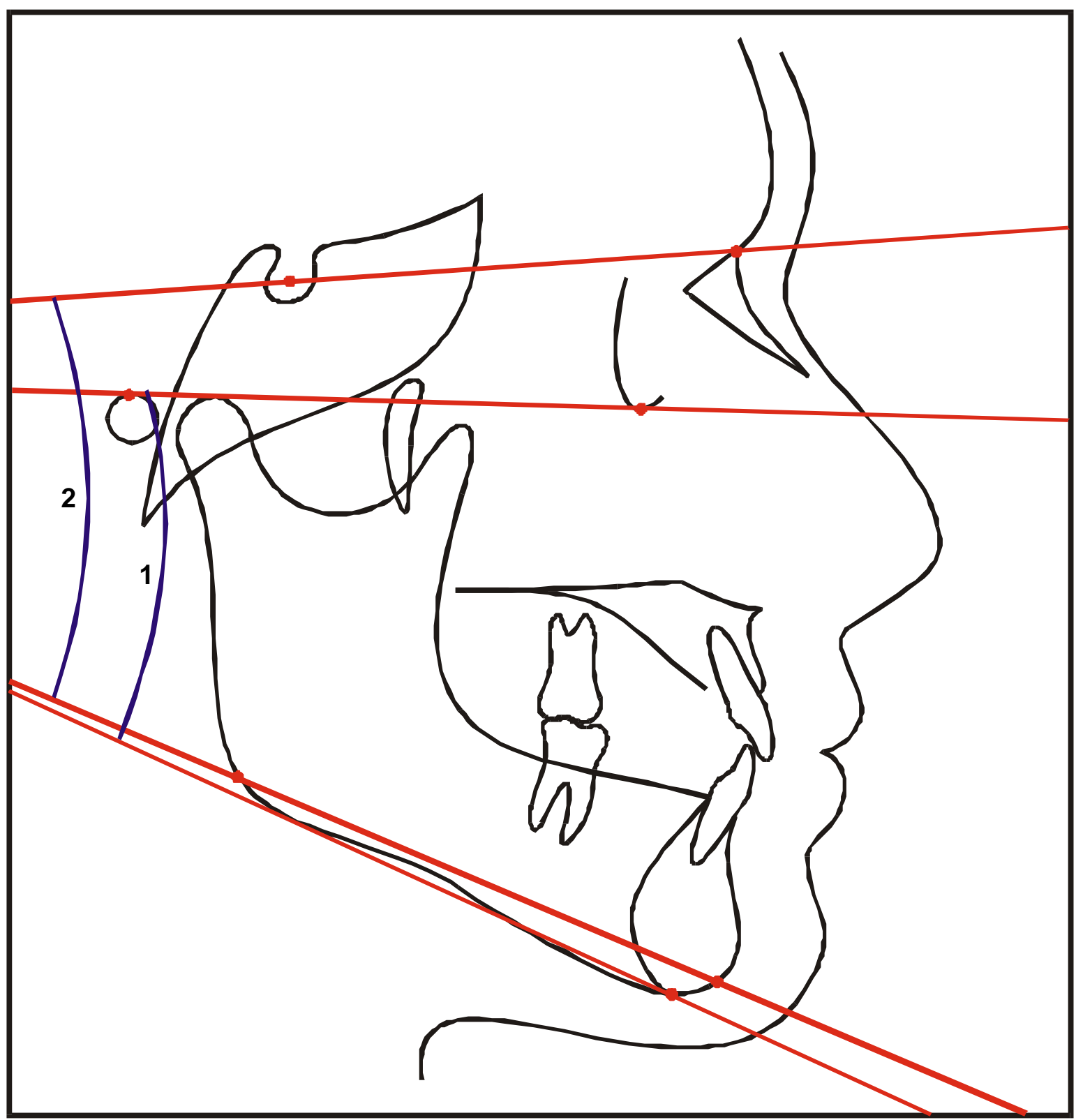

FIGURA 4.4 - Grandezas cefalométricas angulares 


\subsection{7- A OBTENÇÃO DAS MEDIDAS CEFALOMÉTRICAS LINEARES DENTOALVEOLARES}

TABELA 4.6 - Descrição das grandezas cefalométricas lineares dentoalveolares

\begin{tabular}{cll}
\hline Número & Abreviação & \multicolumn{1}{c}{ Descrição } \\
\hline 3 & CMS-Franc & Distância entre a ponta de cúspide \\
& mesial do primeiro molar superior \\
& permanente e o Plano de Francfort \\
& & Distância entre a ponta de cúspide \\
& mesial do primeiro molar superior \\
& & permanente e o Plano Palatino \\
& & Distância entre a ponta de cúspide \\
& CMI-PM & mesial do primeiro molar inferior \\
& & permanente e o Plano Mandibular \\
& & Distância horizontal entre a face distal \\
& do primeiro molar superior permanente \\
& & e a linha PTV \\
& & Distância horizontal entre a face distal \\
& & do primeiro molar inferior permanente e \\
& DMI-PTV & a linha PTV \\
&
\end{tabular}




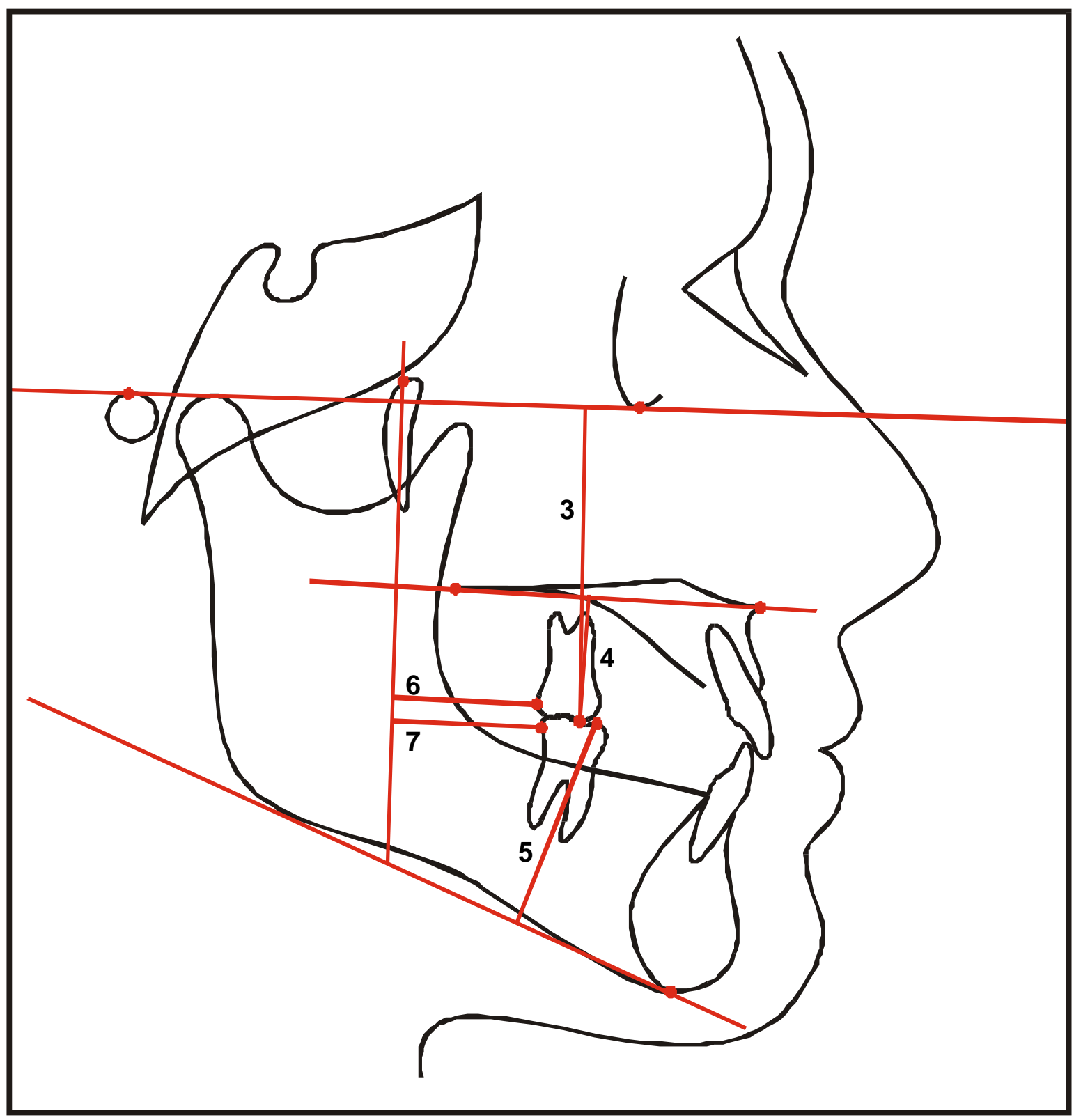

FIGURA 4.5 - Grandezas cefalométricas lineares dentoalveolares 


\subsection{8- A OBTENÇÃO DAS MEDIDAS CEFALOMÉTRICAS LINEARES ESQUELÉTICAS}

TABELA 4.7 - Grandezas cefalométricas lineares esqueléticas

\begin{tabular}{|c|c|c|}
\hline Número & Abreviação & Descrição \\
\hline 8 & PFH & $\begin{array}{l}\text { Distância entre o ponto Ar e o plano } \\
\text { formado pelos pontos mais inferiores da } \\
\text { borda inferior da mandíbula, } \\
\text { tangenciando a borda posterior (ramo } \\
\text { ascendente). }\end{array}$ \\
\hline 9 & $\mathrm{AFH}$ & $\begin{array}{l}\text { Altura facial ântero-inferior segundo } \\
\mathrm{HORN}^{91} \text {, ou seja, distância do ponto Me } \\
\text { perpendicularmente ao plano palatino. }\end{array}$ \\
\hline 10 & AFP & $\begin{array}{l}\text { Altura facial posterior: medida linear } \\
\text { que une o ponto } S \text { ao ponto Go. }\end{array}$ \\
\hline 11 & AFA & $\begin{array}{l}\text { Altura facial anterior: medida linear que } \\
\text { une o ponto } \mathrm{N} \text { ao ponto } \mathrm{Me} \text {. }\end{array}$ \\
\hline 12 & AFAS & $\begin{array}{l}\text { Altura facial ântero-superior: do ponto } \\
\mathrm{N} \text { à projeção do ponto ENA } \\
\text { perpendicular à N-Me, segundo WYLIE } \\
\& \mathrm{JOHNSON}^{216}\end{array}$ \\
\hline 13 & AFAI & $\begin{array}{l}\text { Altura facial ântero-inferior, que } \\
\text { corresponde ao ponto da projeção do } \\
\text { ponto ENA perpendicular à N-Me ao } \\
\text { Me, segundo WYLIE \& JOHNSON }\end{array}$ \\
\hline
\end{tabular}




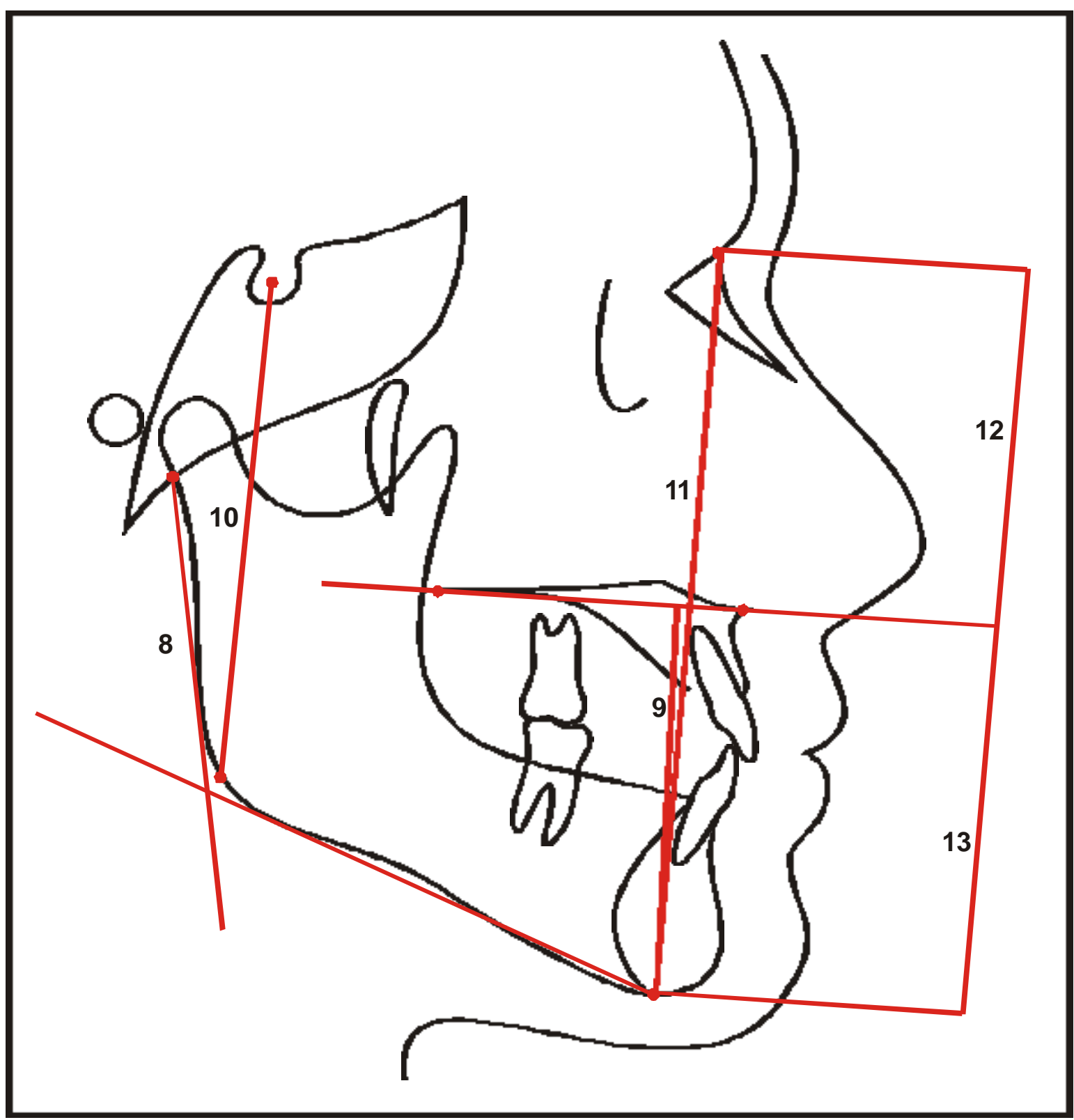

FIGURA 4.6 - Grandezas cefalométricas lineares esqueléticas 


\subsection{9 -PROPORÇÕES ENTRE AS MEDIDAS CEFALOMÉTRICAS VERTICAIS ESQUELÉTICAS}

TABELA 4.8 - Proporções entre as medidas cefalométricas verticais esqueléticas

\begin{tabular}{cl}
\hline Abreviação & \multicolumn{1}{c}{ Descrição } \\
\hline HORN & Proporção entre a medida PFH e a medida \\
& AFH. \\
AFP/ AFA & Proporção ou Quociente de JARABAK ${ }^{186}$ : \\
& entre as medidas AFP (S-Go) e AFA (N-Me). \\
AFAI/AFA & Proporção entre a altura facial ântero-inferior \\
& (ENA-Me) e a altura facial anterior (N-Me) \\
AFAI/AFAS & Proporção entre a altura facial ântero-inferior \\
& (ENA-Me) e a altura facial ântero-superior (N- \\
& ENA) \\
& Proporção entre a altura facial ântero-superior \\
& (N-ENA) e a altura facial anterior (N-Me) \\
\hline
\end{tabular}

Os valores observados para as medidas angulares e lineares foram dispostos em quadros do programa Excel para o encaminhamento à análise estatística. 


\subsection{8- ERRO DO MÉTODO}

Para a avaliação do erro metodológico intra-examinador, selecionou-se aleatoriamente $20 \%$ do número total de telerradiografias da amostra (24 telerradiografias) sendo que a examinadora traçou o cefalograma das mesmas duas vezes consecutivamente, com um intervalo de 15 dias entre um e outro. Em seguida, os pontos cefalométricos foram demarcados manualmente com uma lapiseira provida de grafite $\mathrm{H}$ de $0,3 \mathrm{~mm}$ de diâmetro. Digitalizaram-se os pontos por meio de uma mesa digitalizadora Numonics Accugrid XNT, conectada a um microcomputador Pentium II-166 MMX, para a obtenção das grandezas cefalométricas. Para a realização das mensurações dos pontos digitalizados, utilizou-se o programa Dentofacial Planner 7.02 Plus. A diferença entre a primeira e a segunda medição de cada variável resultou numa tabela montada no programa Excel para posteriores cálculos dos erros metodológicos.

\section{$\underline{E R R O C A S U A L}$}

O erro casual foi obtido com a aplicação da fórmula matemática proposta por DAHLBERG ${ }^{56}$ :

$$
E^{2}=\frac{\sum d^{2}}{2 n}
$$

na qual: "d" indica a diferença entre as mensurações de uma mesma variável e " $n$ " indica o número de pares de cefalogramas comparados. Os valores podem ser visualizados na Tabela 1, sendo que não houve erro casual significante entre os traçados. 


\section{ERRO SISTEMÁTICO}

O erro sistemático foi obtido de acordo com o teste " $t$ " pareado, ao nível de significância de 5\%. Não se observaram diferenças estatisticamente significantes entre os dois traçados, o que se pode constatar na Tabela 4.9. 
TABELA 4.9 - Análise estatística para determinação da confiabilidade do método cefalométrico. Apresentação das médias (X) e desvio-padrão (DP) e do erro casual (Dalhberg- E) e erro sistemático (Teste "t" pareado) para os dois tempos realizados.

\begin{tabular}{|c|c|c|c|c|c|c|c|c|}
\hline \multirow{2}{*}{$M E D I D A$} & \multicolumn{2}{|c|}{ ТЕМРО 1} & \multicolumn{2}{|c|}{ TEMPO 2} & \multirow{2}{*}{$\frac{\text { Dahl. }}{E}$} & \multicolumn{2}{|c|}{ Teste " $t$ " } & \multirow{2}{*}{$S I G$. } \\
\hline & $X 1$ & $D P 1$ & $X 2$ & $D P 2$ & & “t” & $P$ & \\
\hline FMA(graus) & 28,17 & 5,54 & 27,83 & 5,38 & 0,67 & 1,77 & 0,08 & n.s. \\
\hline SN.GoGn(graus) & 32,30 & 6,63 & 32,20 & 6,71 & 0,70 & 0,46 & 0,64 & n.s. \\
\hline CMS-Franc(mm) & 45,46 & 3,33 & 45,21 & 3,15 & 0,54 & 1,60 & 0,12 & n.s. \\
\hline CMS-PP(mm) & 21,85 & 2,35 & 21,73 & 2,12 & 0,52 & 0,78 & 0,43 & n.s. \\
\hline CMI-PM(mm) & 31,06 & 2,84 & 31,05 & 2,85 & 0,50 & 0,05 & 0,95 & n.s. \\
\hline DMS-PTV(mm) & 15,57 & 3,86 & 15,37 & 3,84 & 0,60 & 1,17 & 0,24 & n.s. \\
\hline DMI-PTV(mm) & 15,77 & 4,03 & 15,45 & 3,98 & 0,60 & 1,92 & 0,06 & n.s. \\
\hline PFH(mm) & 44,57 & 4,53 & 44,35 & 4,65 & 0,81 & 0,93 & 0,35 & n.s. \\
\hline $\mathbf{A F H}(\mathbf{m m})$ & 60,63 & 5,59 & 60,46 & 5,49 & 0,35 & 1,78 & 0,08 & n.s. \\
\hline Horn(\%) & 73,95 & 10,57 & 73,97 & 10,89 & 1,36 & 0,06 & 0,95 & n.s. \\
\hline $\operatorname{AFP}(\mathbf{m m})$ & 73,46 & 4,92 & 73,51 & 5,18 & 0,51 & 0,36 & 0,72 & n.s. \\
\hline $\operatorname{AFA}(\mathbf{m m})$ & 111,36 & 7,77 & 111,15 & 7,54 & 0,44 & 1,66 & 0,10 & n.s. \\
\hline AFP/AFA(\%) & 66,15 & 5,28 & 66,15 & 5,41 & 0,59 & 0,02 & 0,98 & n.s. \\
\hline $\operatorname{AFAS}(\mathbf{m m})$ & 49,32 & 3,89 & 49,24 & 3,65 & 0,64 & 0,44 & 0,66 & n.s. \\
\hline $\operatorname{AFAI}(\mathbf{m m})$ & 61,56 & 5,93 & 61,41 & 5,89 & 0,41 & 1,21 & 0,23 & n.s. \\
\hline AFAI/AFA(\%) & 55,67 & 2,86 & 55,68 & 2,76 & 0,44 & 0,12 & 0,90 & n.s. \\
\hline AFAI/AFAS(\%) & 125,35 & 14,69 & 125,65 & 14,47 & 2,42 & 0,42 & 0,67 & n.s. \\
\hline AFAS/AFA(\%) & 44,73 & 2,82 & 44,72 & 2,74 & 0,43 & 0,09 & 0,92 & n.s. \\
\hline
\end{tabular}




\subsection{9- ANÁLISE ESTATÍSTICA}

A análise estatística foi realizada empregando-se o programa Statistica $^{d}$. Para a comparação entre as medidas inicial e final em cada grupo, utilizou-se o teste " $t$ " pareado.

Para a comparação entre os quatro grupos, aplicou-se a análise de variância a um critério fixo (ANOVA). Na observação de um resultado significante, o teste de Tukey seria utilizado com o objetivo de indicar especificamente em quais grupos estaria ocorrendo essa significância.

As possíveis correlações entre as mensurações estudadas foram avaliadas por meio do coeficiente de correlação de Pearson.

Em todos os testes, os resultados foram considerados estatisticamente significantes para $\mathrm{p} \leq 0,05$.

${ }^{d}$ Statistica for Windows - Release 4.3B. - Copywright Statsoft, Inc. 1993. 


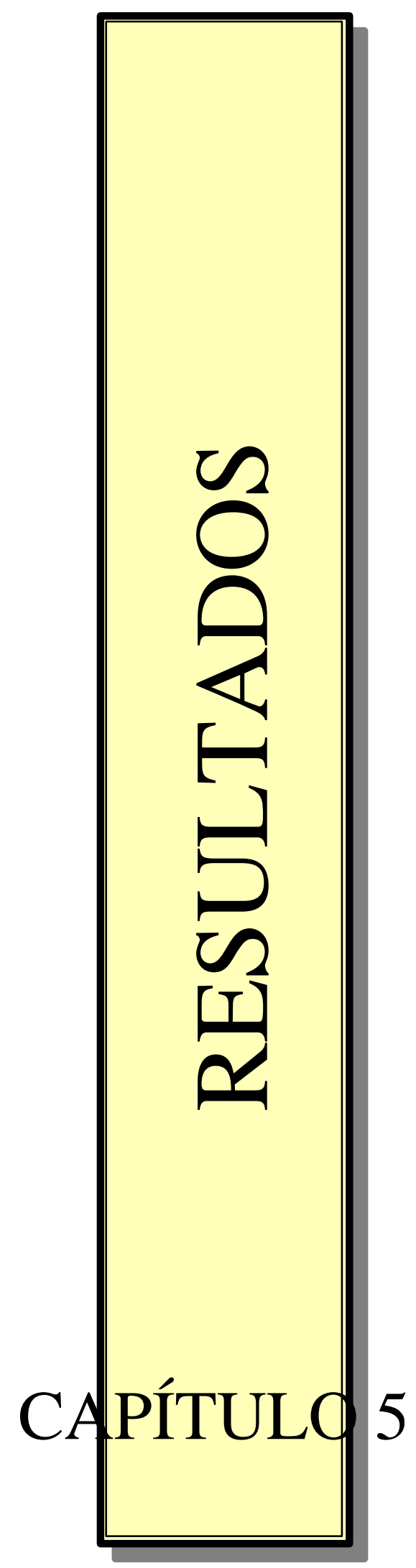




\section{RESULTADOS}

Os resultados apresentados a seguir compreendem as medidas das alterações das grandezas cefalométricas entre as fases inicial e final do tratamento ortodôntico. A avaliação intragrupo foi realizada por meio do teste " $t$ " pareado e a avaliação intergrupos, pela ANOVA (Análise de Variância a um critério fixo). As correlações entre as mensurações foram verificadas pelo coeficiente de correlação de Pearson. O dimorfismo entre os gêneros foi avaliado pelo teste " $t$ ". Todas as medidas foram consideradas estatisticamente significantes para $\mathrm{p} \leq 0,05$. Os valores individuais, de cada paciente, referentes a todas as grandezas cefalométricas utilizadas encontram-se nas tabelas do apêndice.

As médias das idades iniciais e finais dos pacientes e o tempo de tratamento avaliado encontram-se dispostos em uma tabela de acordo com cada grupo.(TABELAS 5.1 e 5.2)

TABELA 5.1 - Média das idades iniciais e finais dos jovens nos quatro grupos e o tempo de tratamento.

\begin{tabular}{|c|c|c|c|}
\hline \multirow{2}{*}{ GRUPO } & $\begin{array}{c}\text { IDADE } \\
\text { INICIAL }\end{array}$ & $\begin{array}{c}\text { IDADE } \\
\text { FINAL }\end{array}$ & TEMPO DE TRATAMENTO \\
\hline I & 12,27 & 14,76 & 2,45 \\
\hline II & 11,87 & 13,89 & 2,01 \\
\hline III & 12,28 & 15,20 & 2,93 \\
\hline IV & 12,15 & 14,73 & 2,58 \\
\hline I+II+III+IV & 12,14 & 14,64 & 2,49 \\
\hline \multirow{2}{*}{ ANOVA } & $\mathrm{f}=0,15$ & $\mathrm{f}=0,82$ & $\mathrm{f}=2,47$ \\
& $\mathrm{p}=0,932$ & $\mathrm{p}=0,487$ & $\mathrm{p}=0,07$ \\
\hline
\end{tabular}


TABELA 5.2 - Média das idades iniciais, finais e do tempo de tratamento dos jovens nos quatro grupos, divididos de acordo com o gênero.

\begin{tabular}{|c|c|c|c|c|c|}
\hline GRUPO & GÊNERO & $\begin{array}{c}\mathbf{N}^{\mathbf{0}} \text { DE } \\
\text { PACIENTES }\end{array}$ & $\begin{array}{c}\text { IDADE } \\
\text { INICIAL }\end{array}$ & $\begin{array}{c}\text { IDADE } \\
\text { FINAL }\end{array}$ & $\begin{array}{c}\text { TEMPO DE } \\
\text { TRATAMENTO }\end{array}$ \\
\hline I & F & 9 & 12,03 & 14,36 & 2,32 \\
\hline I & M & 6 & 12,72 & 15,36 & 2,63 \\
\hline II & F & 8 & 11,80 & 13,63 & 1,83 \\
\hline II & M & 7 & 11,96 & 14,19 & 2,22 \\
\hline III & F & 7 & 12,64 & 15,98 & 3,34 \\
\hline III & M & 7 & 11,92 & 14,42 & 2,52 \\
\hline IV & F & 7 & 12,33 & 15,29 & 2,96 \\
\hline IV & M & 8 & 12,00 & 14,25 & 2,25 \\
\hline
\end{tabular}




\section{1- COMPARAÇÃO INTRAGRUPO}

\subsection{1- Grupo I}

De acordo com o teste estatístico realizado para identificar as diferenças significantes entre o início e o final do tratamento ortodôntico no Grupo I, a maioria das grandezas cefalométricas apresentou diferenças estatisticamente significantes como pode se constatar na Tabela 5.3. 
TABELA 5.3 - Apresentação das alterações médias ocorridas durante o tratamento de pacientes do Grupo I $(\mathrm{N}=15)$

\begin{tabular}{|c|c|c|c|c|c|c|c|c|c|}
\hline$M E D I D A$ & $X i$ & D.P. & $\overline{X f}$ & D.P. & $\overline{X f-X i}$ & D.P. & "t $t "$ & $P$ & SIG. \\
\hline FMA(graus) & 28,79 & 3,37 & 28,36 & 4,48 & $-0,43$ & 2,09 & 0,80 & 0,43 & n.s. \\
\hline SN.GoGn(graus) & 32,36 & 5,10 & 31,54 & 5,73 & $-0,82$ & 2,04 & 1,55 & 0,14 & n.s. \\
\hline CMS-Franc(mm) & 44,30 & 2,91 & 47,93 & 3,77 & 3,62 & 2,51 & $-5,58$ & 0,00 & s. \\
\hline CMS-PP(mm) & 20,68 & 1,10 & 22,74 & 2,06 & 2,06 & 1,64 & $-4,87$ & 0,00 & s. \\
\hline CMI-PM(mm) & 30,00 & 2,12 & 32,05 & 2,88 & 2,05 & 2,00 & $-3,95$ & 0,00 & s. \\
\hline DMS-PTV(mm) & 11,78 & 3,47 & 15,70 & 2,88 & 3,92 & 1,95 & $-7,77$ & 0,00 & s. \\
\hline DMI-PTV(mm) & 12,30 & 3,40 & 16,15 & 2,94 & 3,85 & 1,93 & $-7,69$ & 0,00 & s. \\
\hline PFH(mm) & 41,58 & 3,69 & 44,73 & 4,82 & 3,14 & 2,72 & $-4,47$ & 0,00 & s. \\
\hline AFH(mm) & 59,36 & 2,94 & 62,18 & 4,67 & 2,82 & 2,58 & $-4,21$ & 0,00 & s. \\
\hline $\operatorname{Horn}(\%)$ & 70,07 & 5,66 & 72,21 & 8,37 & 2,14 & 3,93 & $-2,10$ & 0,05 & s. \\
\hline $\operatorname{AFP}(\mathbf{m m})$ & 71,08 & 5,20 & 75,20 & 6,36 & 4,11 & 3,37 & $-4,72$ & 0,00 & s. \\
\hline $\operatorname{AFA}(\mathbf{m m})$ & 108,9 & 8,32 & 113,4 & 9,12 & 4,52 & 3,81 & $-4,59$ & 0,00 & s. \\
\hline $\operatorname{AFP} / A F A(\%)$ & 65,36 & 3,43 & 66,39 & 4,36 & 1,02 & 1,82 & $-2,17$ & 0,04 & s. \\
\hline $\operatorname{AFAS}(\mathbf{m m})$ & 47,96 & 5,98 & 50,10 & 5,70 & 2,14 & 2,69 & $-3,07$ & 0,00 & s. \\
\hline $\operatorname{AFAI}(\mathbf{m m})$ & 60,32 & 3,16 & 62,78 & 4,92 & 2,45 & 2,42 & $-3,91$ & 0,00 & s. \\
\hline $\operatorname{AFAI/AFA}(\%)$ & 56,12 & 2,58 & 55,89 & 2,56 & $-0,22$ & 1,57 & 0,55 & 0,58 & n.s. \\
\hline AFAI/AFAS(\%) & 127,2 & 13,73 & 126,3 & 12,84 & $-0,95$ & 8,73 & 0,42 & 0,67 & n.s. \\
\hline AFAS/AFA(\%) & 44,35 & 2,56 & 44,50 & 2,49 & 0,15 & 1,58 & $-0,37$ & 0,71 & n.s. \\
\hline
\end{tabular}




\subsubsection{GRUPO II}

A avaliação das diferenças entre o início e o final do tratamento ortodôntico no grupo formado por jovens com Classe I tratados sem extração demonstrou significância para a maioria das grandezas cefalométricas verificadas, de acordo com o teste estatístico empregado. Os dados desta avaliação encontram-se expostos na Tabela 5.4. 
TABELA 5.4 - Apresentação das alterações médias ocorridas durante o tratamento de pacientes do Grupo II $(\mathrm{N}=15)$

\begin{tabular}{|c|c|c|c|c|c|c|c|c|c|}
\hline$M E D I D A$ & $X i$ & D.P. & $X f$ & D.P. & $X f-X i$ & D.P. & "t $t "$ & $p$ & $S I G$. \\
\hline FMA(graus) & 26,86 & 5,23 & 27,04 & 4,62 & 0,17 & 3,40 & $-0,19$ & 0,84 & n.s. \\
\hline SN.GoGn(graus) & 31,38 & 5,37 & 32,18 & 6,01 & 0,80 & 2,65 & $-1,16$ & 0,26 & n.s. \\
\hline CMS-Franc(mm) & 43,20 & 3,98 & 45,96 & 4,45 & 2,75 & 1,89 & $-5,63$ & 0,00 & s. \\
\hline CMS-PP(mm) & 20,46 & 2,68 & 22,06 & 2,56 & 1,59 & 1,69 & $-3,63$ & 0,00 & s. \\
\hline CMI-PM(mm) & 29,72 & 1,79 & 31,77 & 1,88 & 2,04 & 2,20 & $-3,60$ & 0,00 & s. \\
\hline DMS-PTV(mm) & 10,55 & 3,45 & 12,66 & 3,22 & 2,11 & 4,03 & $-2,02$ & 0,06 & n.s. \\
\hline DMI-PTV(mm) & 11,05 & 3,57 & 13,43 & 3,37 & 2,38 & 3,94 & $-2,33$ & 0,03 & s. \\
\hline PFH(mm) & 42,82 & 4,93 & 45,28 & 4,63 & 2,46 & 2,51 & $-3,78$ & 0,00 & s. \\
\hline $\mathbf{A F H}(\mathbf{m m})$ & 59,27 & 3,25 & 62,82 & 3,73 & 3,55 & 2,71 & $-5,06$ & 0,00 & s. \\
\hline $\operatorname{Horn}(\%)$ & 72,17 & 6,24 & 72,12 & 6,25 & $-0,05$ & 3,21 & 0,06 & 0,94 & n.s. \\
\hline $\operatorname{AFP}(\mathbf{m m})$ & 71,70 & 6,27 & 75,54 & 5,68 & 3,84 & 2,77 & $-5,35$ & 0,00 & s. \\
\hline AFA(mm) & 108,38 & 5,20 & 114,36 & 6,53 & 5,97 & 4,38 & $-5,27$ & 0,00 & $\mathrm{~s}$ \\
\hline $\operatorname{AFP} / \operatorname{AFA}(\%)$ & 66,12 & 4,36 & 66,14 & 4,55 & 0,02 & 1,85 & $-0,04$ & 0,96 & n.s. \\
\hline AFAS(mm) & 47,86 & 4,10 & 50,58 & 3,92 & 2,72 & 2,77 & $-3,79$ & 0,00 & $\mathrm{~s}$ \\
\hline AFAI(mm) & 60,02 & 2,91 & 63,33 & 3,59 & 3,30 & 2,84 & $-4,50$ & 0,00 & $\mathrm{~s}$ \\
\hline AFAI/AFA(\%) & 55,88 & 2,44 & 55,76 & 1,76 & $-0,12$ & 1,53 & 0,30 & 0,76 & n.s. \\
\hline AFAI/AFAS(\%) & 126,34 & 13,59 & 125,64 & 8,98 & $-0,70$ & 8,96 & 0,30 & 0,76 & n.s. \\
\hline AFAS/AFA(\%) & 44,49 & 2,48 & 44,52 & 1,74 & 0,02 & 1,56 & $-0,06$ & 0,94 & n.s. \\
\hline
\end{tabular}




\subsubsection{GRUPO III}

A avaliação das diferenças entre o início e o final do tratamento ortodôntico no grupo formado por jovens com Classe II, $1^{\text {a }}$ divisão tratados com extração dos quatro primeiros pré-molares também demonstrou significância para a maioria das grandezas cefalométricas, como pode-se observar na Tabela 5.5. 
TABELA 5.5- Apresentação das alterações médias ocorridas durante o tratamento de pacientes do Grupo III ( $\mathrm{N}=14)$

\begin{tabular}{|c|c|c|c|c|c|c|c|c|c|}
\hline$M E D I D A$ & $X i$ & D.P. & $X f$ & D.P. & $X f-X i$ & D.P. & "t $t "$ & $p$ & $S I G$. \\
\hline FMA(graus) & 25,90 & 6,05 & 25,24 & 7,06 & $-0,66$ & 2,81 & 0,87 & 0,39 & n.s. \\
\hline SN.GoGn(graus) & 31,17 & 6,29 & 30,10 & 6,97 & $-1,07$ & 2,53 & 1,58 & 0,13 & n.s. \\
\hline CMS-Franc(mm) & 43,58 & 3,20 & 46,77 & 3,97 & 3,18 & 2,46 & $-4,82$ & 0,00 & s. \\
\hline CMS-PP(mm) & 21,06 & 2,20 & 22,46 & 2,46 & 1,40 & 1,50 & $-3,48$ & 0,00 & s. \\
\hline CMI-PM(mm) & 29,15 & 2,48 & 31,90 & 2,34 & 2,75 & 1,67 & $-6,14$ & 0,00 & s. \\
\hline DMS-PTV(mm) & 13,13 & 3,44 & 16,17 & 3,97 & 3,03 & 2,47 & $-4,58$ & 0,00 & s. \\
\hline DMI-PTV(mm) & 12,44 & 3,71 & 16,70 & 4,09 & 4,26 & 2,53 & $-6,28$ & 0,00 & s. \\
\hline PFH(mm) & 41,82 & 4,22 & 45,34 & 3,52 & 3,51 & 2,20 & $-5,97$ & 0,00 & s. \\
\hline $\mathbf{A F H}(\mathbf{m m})$ & 58,19 & 4,92 & 60,80 & 5,59 & 2,61 & 2,29 & $-4,25$ & 0,00 & s. \\
\hline $\operatorname{Horn}(\%)$ & 72,25 & 8,99 & 75,26 & 10,47 & 3,00 & 4,10 & $-2,73$ & 0,01 & s. \\
\hline $\operatorname{AFP}(\mathbf{m m})$ & 72,52 & 4,84 & 77,40 & 4,05 & 4,88 & 2,69 & $-6,78$ & 0,00 & s. \\
\hline $\operatorname{AFA}(\mathbf{m m})$ & 109,02 & 7,36 & 113,62 & 7,68 & 4,60 & 2,90 & $-5,91$ & 0,00 & s. \\
\hline $\operatorname{AFP} / \operatorname{AFA}(\%)$ & 66,70 & 4,97 & 68,36 & 5,39 & 1,66 & 2,04 & $-3,04$ & 0,00 & s. \\
\hline AFAS(mm) & 49,57 & 2,99 & 51,85 & 3,07 & 2,27 & 1,58 & $-5,35$ & 0,00 & s. \\
\hline AFAI(mm) & 58,91 & 5,07 & 61,22 & 5,93 & 2,31 & 2,34 & $-3,69$ & 0,00 & s. \\
\hline $\operatorname{AFAI} / \operatorname{AFA}(\%)$ & 54,46 & 1,86 & 54,29 & 2,47 & $-0,17$ & 1,23 & 0,51 & 0,61 & n.s. \\
\hline AFAI/AFAS(\%) & 118,93 & 9,17 & 118,32 & 12,67 & $-0,61$ & 6,01 & 0,38 & 0,70 & n.s. \\
\hline $\operatorname{AFAS/AFA(\% )}$ & 45,92 & 1,79 & 46,10 & 2,47 & 0,17 & 1,25 & $-0,53$ & 0,60 & n.s. \\
\hline
\end{tabular}




\subsubsection{GRUPO IV}

Novamente, houve significância para a maioria das grandezas cefalométricas estudadas no grupo constituído por jovens com Classe II, $1^{\text {a }}$ divisão, tratados sem extração. Os dados desta avaliação encontram-se expostos na Tabela 5.6. 
TABELA 5.6- Apresentação das alterações médias ocorridas durante o tratamento de pacientes do Grupo IV $(\mathrm{N}=15)$

\begin{tabular}{|c|c|c|c|c|c|c|c|c|c|}
\hline$M E D I D A$ & $X i$ & D.P. & $X f$ & D.P. & $X f-X i$ & D.P. & "t $t "$ & $p$ & $S I G$. \\
\hline FMA(graus) & 25,96 & 3,59 & 25,20 & 3,42 & $-0,76$ & 2,31 & 1,28 & 0,21 & n.s. \\
\hline SN.GoGn(graus) & 31,89 & 3,13 & 31,49 & 3,61 & $-0,40$ & 2,14 & 0,72 & 0,48 & n.s. \\
\hline CMS-Franc(mm) & 43,16 & 4,12 & 46,15 & 3,57 & 2,99 & 2,47 & $-4,69$ & 0,00 & s. \\
\hline CMS-PP(mm) & 20,94 & 2,91 & 22,41 & 2,68 & 1,46 & 1,27 & $-4,45$ & 0,00 & s. \\
\hline CMI-PM(mm) & 29,34 & 2,24 & 31,28 & 2,39 & 1,94 & 1,60 & $-4,69$ & 0,00 & s. \\
\hline DMS-PTV(mm) & 12,52 & 4,23 & 13,78 & 4,37 & 1,26 & 2,65 & $-1,84$ & 0,08 & n.s. \\
\hline DMI-PTV(mm) & 11,68 & 4,39 & 14,45 & 5,09 & 2,77 & 2,42 & $-4,43$ & 0,00 & s. \\
\hline PFH(mm) & 41,88 & 4,21 & 44,99 & 3,57 & 3,10 & 2,59 & $-4,63$ & 0,00 & s. \\
\hline AFH(mm) & 59,10 & 4,78 & 62,64 & 4,54 & 3,54 & 2,10 & $-6,51$ & 0,00 & s. \\
\hline $\operatorname{Horn}(\%)$ & 70,96 & 5,30 & 71,96 & 5,24 & 0,99 & 3,32 & $-1,15$ & 0,26 & n.s. \\
\hline $\operatorname{AFP}(\mathbf{m m})$ & 71,66 & 6,30 & 76,37 & 5,85 & 4,71 & 3,45 & $-5,29$ & 0,00 & s. \\
\hline $\operatorname{AFA}(\mathbf{m m})$ & 109,09 & 7,59 & 114,75 & 6,59 & 5,66 & 4,29 & $-5,10$ & 0,00 & s. \\
\hline $\operatorname{AFP} / \mathbf{A F A}(\%)$ & 65,67 & 2,98 & 66,55 & 3,32 & 0,88 & 1,70 & $-2,00$ & 0,06 & n.s. \\
\hline $\operatorname{AFAS}(\mathbf{m m})$ & 48,08 & 3,97 & 50,55 & 3,83 & 2,46 & 3,06 & $-3,11$ & 0,00 & s. \\
\hline AFAI(mm) & 60,50 & 4,92 & 63,85 & 4,95 & 3,34 & 2,05 & $-6,29$ & 0,00 & s. \\
\hline $\operatorname{AFAI} / \operatorname{AFA}(\%)$ & 55,91 & 2,21 & 55,93 & 2,60 & 0,02 & 1,48 & $-0,05$ & 0,95 & n.s. \\
\hline AFAI/AFAS(\%) & 126,28 & 11,38 & 126,94 & 14,00 & 0,66 & 8,07 & $-0,31$ & 0,75 & n.s. \\
\hline AFAS/AFA(\%) & 44,45 & 2,16 & 44,32 & 2,58 & $-0,12$ & 1,41 & 0,34 & 0,73 & n.s. \\
\hline
\end{tabular}




\subsection{COMPARAÇÃO DAS DIFERENÇAS ENTRE OS GÊNEROS}

\subsubsection{COMPARAÇÃO DAS DIFERENÇAS ENTRE OS GÊNEROS NO GRUPO I}

A avaliação das diferenças entre as alterações cefalométricas ocorridas no gênero feminino e no masculino verificou que houve significância apenas nas medidas que representam o movimento ântero-posterior dos molares superiores e inferiores em relação à linha PTV, conforme se verifica na Tabela 5.7. 
TABELA 5.7- Comparação entre os gêneros feminino e masculino das alterações médias ocorridas durante o tratamento do Grupo I

\begin{tabular}{|c|c|c|c|c|c|c|c|}
\hline$M E D I D A$ & $X f$ & D.P.f & $X m$ & D.P.m & "tt" & $p$ & $S I G$. \\
\hline FMA(graus) & 0,34 & 2,13 & $-1,60$ & 1,49 & 1,92 & 0,07 & n.s. \\
\hline SN.GoGn(graus) & $-0,55$ & 1,98 & $-1,21$ & 2,24 & 0,59 & 0,55 & n.s. \\
\hline CMS-Franc(mm) & 3,78 & 2,93 & 3,38 & 1,96 & 0,29 & 0,77 & n.s. \\
\hline CMS-PP(mm) & 1,71 & 1,65 & 2,60 & 1,60 & $-1,02$ & 0,32 & n.s. \\
\hline CMI-PM(mm) & 1,70 & 2,41 & 2,58 & 1,17 & $-0,82$ & 0,42 & n.s. \\
\hline DMS-PTV(mm) & 3,13 & 2,08 & 5,10 & 0,96 & $-2,14$ & 0,05 & s. \\
\hline DMI-PTV(mm) & 2,84 & 1,77 & 5,36 & 0,94 & $-3,16$ & 0,00 & s. \\
\hline PFH(mm) & 2,28 & 2,82 & 4,43 & 2,16 & $-1,56$ & 0,14 & n.s. \\
\hline $\operatorname{AFH}(\mathbf{m m})$ & 2,16 & 2,75 & 3,80 & 2,16 & $-1,21$ & 0,24 & n.s. \\
\hline Horn(\%) & 1,51 & 3,88 & 3,08 & 4,16 & $-0,74$ & 0,46 & n.s. \\
\hline $\operatorname{AFP}(\mathbf{m m})$ & 3,15 & 3,33 & 5,55 & 3,14 & $-1,39$ & 0,18 & n.s. \\
\hline $\operatorname{AFA}(\mathbf{m m})$ & 0,60 & 1,68 & 1,66 & 2,00 & $-1,11$ & 0,28 & n.s. \\
\hline $\operatorname{AFP} / \operatorname{AFA}(\%)$ & 3,76 & 4,13 & 5,66 & 3,30 & $-0,94$ & 0,36 & n.s. \\
\hline $\operatorname{AFAS}(\mathbf{m m})$ & 1,97 & 3,20 & 2,38 & 1,94 & $-0,27$ & 0,78 & n.s. \\
\hline $\operatorname{AFAI}(\mathbf{m m})$ & 1,77 & 2,51 & 3,46 & 2,06 & $-1,36$ & 0,19 & n.s. \\
\hline AFAI/AFA(\%) & $-0,46$ & 1,90 & 0,13 & 0,95 & $-0,70$ & 0,49 & n.s. \\
\hline AFAI/AFAS(\%) & $-2,51$ & 10,62 & 1,38 & 4,71 & $-0,83$ & 0,41 & n.s. \\
\hline AFAS/AFA(\%) & 0,46 & 1,89 & $-0,31$ & 0,92 & 0,93 & 0,36 & n.s. \\
\hline
\end{tabular}




\subsubsection{COMPARAÇÃO DAS DIFERENÇAS ENTRE OS GÊNEROS NO GRUPO II}

A avaliação das diferenças entre as alterações cefalométricas ocorridas no gênero feminino e no masculino não demonstrou significância em nenhuma das medidas cefalométricas estudadas, conforme se observa na Tabela 5.8. 
TABELA 5.8 - Comparação entre os gêneros feminino e masculino das alterações médias ocorridas durante o tratamento do Grupo II

\begin{tabular}{|c|cc|cc|c|c|c|}
\hline MEDIDA & $\boldsymbol{X} \boldsymbol{f}$ & $\boldsymbol{D . P . f}$ & $\boldsymbol{X} \boldsymbol{m}$ & $\boldsymbol{D . P . m}$ & “t” & $\boldsymbol{P}$ & $\boldsymbol{S I G .}$ \\
\hline FMA(graus) & 1,33 & 2,58 & $-1,15$ & 3,91 & 1,47 & 0,16 & n.s. \\
SN.GoGn(graus) & 1,51 & 3,29 & $-0,01$ & 1,50 & 1,12 & 0,28 & n.s. \\
CMS-Franc(mm) & 3,12 & 2,32 & 2,32 & 1,29 & 0,80 & 0,43 & n.s. \\
CMS-PP(mm) & 1,88 & 1,97 & 1,25 & 1,38 & 0,70 & 0,49 & n.s. \\
CMI-PM(mm) & 1,31 & 1,64 & 2,88 & 2,56 & $-1,43$ & 0,17 & n.s. \\
DMS-PTV(mm) & 0,51 & 2,90 & 3,94 & 4,56 & $-1,76$ & 0,10 & n.s. \\
DMI-PTV(mm) & 0,76 & 3,15 & 4,22 & 4,16 & $-1,83$ & 0,08 & n.s. \\
PFH(mm) & 2,60 & 2,03 & 2,30 & 3,14 & 0,22 & 0,82 & n.s. \\
AFH(mm) & 3,33 & 2,24 & 3,80 & 3,35 & $-0,31$ & 0,75 & n.s. \\
Horn(\%) & 0,50 & 3,03 & $-0,68$ & 3,52 & 0,69 & 0,49 & n.s. \\
AFP(mm) & 3,21 & 1,64 & 4,55 & 3,69 & $-0,93$ & 0,36 & n.s. \\
AFA(mm) & 5,67 & 4,60 & 6,31 & 4,44 & $-0,27$ & 0,78 & n.s. \\
AFP/AFA(\%) & $-0,40$ & 2,03 & 0,50 & 1,65 & $-0,93$ & 0,36 & n.s. \\
AFAS(mm) & 2,47 & 3,51 & 3,00 & 1,83 & $-0,35$ & 0,72 & n.s. \\
AFAI(mm) & 3,07 & 2,09 & 3,57 & 3,67 & $-0,32$ & 0,74 & n.s. \\
AFAI/AFA(\%) & $-0,11$ & 1,89 & $-0,12$ & 1,13 & 0,01 & 0,98 & n.s. \\
AFAI/AFAS(\%) & $-1,25$ & 11,42 & $-0,07$ & 5,87 & $-0,24$ & 0,81 & n.s. \\
\hline AFAS/AFA(\%) & 0,15 & 1,82 & $-0,11$ & 1,33 & 0,31 & 0,75 & n.s. \\
\hline
\end{tabular}




\subsubsection{COMPARAÇÃO DAS DIFERENÇAS ENTRE OS GÊNEROS NO GRUPO III}

A avaliação das diferenças entre as alterações cefalométricas ocorridas no gênero feminino e no masculino verificou que houve significância apenas nas medidas CMI-PP, PFHe AFP, conforme se verifica na Tabela 5.9. 
TABELA 5.9 - Comparação entre os gêneros feminino e masculino das alterações médias ocorridas durante o tratamento do Grupo III

\begin{tabular}{|c|cc|cc|c|c|c|}
\hline MEDIDA & $\boldsymbol{X} \boldsymbol{f}$ & $\boldsymbol{D . P . f}$ & $\boldsymbol{X} \boldsymbol{m}$ & $\boldsymbol{D . P .} \boldsymbol{m}$ & “t” & $\boldsymbol{P}$ & $\boldsymbol{S I G .}$ \\
\hline FMA(graus) & $-0,87$ & 3,84 & $-0,44$ & 1,50 & $-0,27$ & 0,78 & n.s. \\
SN.GoGn(graus) & $-0,17$ & 2,92 & $-1,97$ & 1,87 & 1,37 & 0,19 & n.s. \\
CMS-Franc(mm) & 2,02 & 2,31 & 4,34 & 2,17 & $-1,92$ & 0,07 & n.s. \\
CMS-PP(mm) & 1,11 & 1,53 & 1,68 & 1,53 & $-0,69$ & 0,49 & n.s. \\
CMI-PM(mm) & 1,84 & 0,84 & 3,67 & 1,85 & $-2,37$ & 0,03 & s. \\
DMS-PTV(mm) & 2,40 & 2,57 & 3,67 & 2,38 & $-0,95$ & 0,35 & n.s. \\
DMI-PTV(mm) & 3,48 & 2,81 & 5,04 & 2,13 & $-1,16$ & 0,26 & n.s. \\
PFH(mm) & 2,08 & 2,17 & 4,94 & 0,98 & $-3,15$ & 0,00 & s. \\
AFH(mm) & 1,48 & 1,91 & 3,74 & 2,18 & $-2,05$ & 0,06 & n.s. \\
Horn(\%) & 2,22 & 5,10 & 3,78 & 3,01 & $-0,69$ & 0,50 & n.s. \\
AFP(mm) & 2,85 & 2,15 & 6,91 & 1,21 & $-4,33$ & 0,00 & s. \\
AFA(mm) & 3,27 & 2,04 & 5,92 & 3,17 & $-1,86$ & 0,08 & n.s. \\
AFP/AFA(\%) & 0,72 & 2,29 & 2,60 & 1,32 & $-1,86$ & 0,08 & n.s. \\
AFAS(mm) & 1,82 & 1,29 & 2,71 & 1,82 & $-1,04$ & 0,31 & n.s. \\
AFAI(mm) & 1,47 & 2,13 & 3,15 & 2,38 & $-1,39$ & 0,18 & n.s. \\
AFAI/AFA(\%) & $-0,35$ & 1,32 & 0,01 & 1,21 & $-0,54$ & 0,59 & n.s. \\
AFAI/AFAS(\%) & $-1,21$ & 6,62 & $-0,01$ & 5,81 & $-0,36$ & 0,72 & n.s. \\
\hline AFAS/AFA(\%) & 0,32 & 1,28 & 0,02 & 1,30 & 0,43 & 0,67 & n.s. \\
\hline
\end{tabular}




\subsubsection{COMPARAÇÃO DAS DIFERENÇAS ENTRE OS GÊNEROS NO GRUPO IV}

A avaliação das diferenças entre as alterações cefalométricas ocorridas no gênero feminino e no masculino verificou que não houve significância em nenhuma das medidas cefalométricas estudadas, conforme se verifica na Tabela 5.10. 
TABELA 5.10 - Comparação entre os gêneros feminino e masculino das alterações médias ocorridas durante o tratamento do Grupo IV

\begin{tabular}{|c|c|c|c|c|c|c|c|}
\hline$M E D I D A$ & $X f$ & D.P.f & $X m$ & D.P.m & "tt" & $p$ & SIG. \\
\hline FMA(graus) & $-0,45$ & 2,46 & $-1,03$ & 2,30 & 0,47 & 0,64 & n.s. \\
\hline SN.GoGn(graus) & 0,60 & 2,03 & $-1,27$ & 1,93 & 1,82 & 0,09 & n.s. \\
\hline CMS-Franc(mm) & 2,88 & 1,89 & 3,08 & 3,01 & $-0,15$ & 0,88 & n.s. \\
\hline CMS-PP(mm) & 1,61 & 1,02 & 1,33 & 1,52 & 0,40 & 0,69 & n.s. \\
\hline CMI-PM(mm) & 1,77 & 1,86 & 2,08 & 1,43 & $-0,36$ & 0,71 & n.s. \\
\hline DMS-PTV(mm) & 1,05 & 3,61 & 1,45 & 1,66 & $-0,27$ & 0,78 & n.s. \\
\hline DMI-PTV(mm) & 2,65 & 3,23 & 2,87 & 1,65 & $-0,16$ & 0,86 & n.s. \\
\hline PFH(mm) & 2,41 & 2,70 & 3,71 & 2,50 & $-0,96$ & 0,35 & n.s. \\
\hline AFH(mm) & 3,37 & 1,81 & 3,70 & 2,45 & $-0,29$ & 0,77 & n.s. \\
\hline Horn $(\%)$ & 0,04 & 4,02 & 1,82 & 2,55 & $-1,03$ & 0,31 & n.s. \\
\hline $\operatorname{AFP}(\mathbf{m m})$ & 3,11 & 2,87 & 6,11 & 3,45 & $-1,81$ & 0,09 & n.s. \\
\hline $\operatorname{AFA}(\mathbf{m m})$ & 4,58 & 2,91 & 6,60 & 5,24 & $-0,89$ & 0,38 & n.s. \\
\hline $\operatorname{AFP/AFA(\% )}$ & 0,08 & 1,76 & 1,57 & 1,39 & $-1,82$ & 0,09 & n.s. \\
\hline $\operatorname{AFAS}(\mathbf{m m})$ & 1,38 & 2,11 & 3,41 & 3,56 & $-1,31$ & 0,21 & n.s. \\
\hline AFAI(mm) & 3,32 & 1,52 & 3,36 & 2,54 & $-0,03$ & 0,97 & n.s. \\
\hline $\operatorname{AFAI/AFA(\% )}$ & 0,52 & 1,19 & $-0,42$ & 1,63 & 1,26 & 0,22 & n.s. \\
\hline AFAI/AFAS(\%) & 3,08 & 6,37 & $-1,46$ & 9,20 & 1,09 & 0,29 & n.s. \\
\hline AFAS/AFA(\%) & $-0,64$ & 1,10 & 0,32 & 1,57 & $-1,35$ & 0,19 & n.s. \\
\hline
\end{tabular}




\subsection{COMPARAÇÃO DA DIFERENÇA ENTRE OS GRUPOS}

A análise intergrupos, por meio do teste estatístico ANOVA (Análise de Variância a um critério fixo), não constatou diferença estatisticamente significante para nenhuma das grandezas cefalométricas estudadas, como é observado na Tabela 5.11.

As grandezas angulares referentes ao padrão de crescimento facial, SN.GoGn e FMA, apesar de não mostrarem diferenças estatisticamente significantes, revelaram que o Grupo II (Tabela 5.11 e Figuras 5.1 e 5.2) foi o único que apresentou um suave aumento.

As grandezas lineares dentárias, CMS-Franc, CMS-PP, CMI-PM, DMS-PTV, DMI-PTV, comportaram-se com similaridade entre os grupos, tendo seus valores aumentados em toda a amostra. Apesar de insuficiente para demonstrar significado estatístico, verificou-se um maior movimento ânteroposterior (mesialização) e no sentido vertical dos molares superiores e inferiores nos grupos I e III, ou seja, aqueles tratados com extração dos quatro primeiros pré-molares.

Em relação às grandezas lineares esqueléticas, houve bastante semelhança entre os quatro grupos, todas aumentando seus valores após o tratamento ortodôntico. As medidas lineares referentes à altura facial posterior, PFH e AFP, comportaram-se de modo similar nos quatro grupos, ambas apresentando aumento de seus valores após o tratamento ortodôntico. As medidas cefalométricas referentes à altura facial anterior, tanto total como 


\section{Resultadbs}

da porção inferior, demonstraram uma tendência para maiores aumentos nos grupos sem extração (Grupos II e IV).

Com relação à proporção entre a altura facial posterior e a anterior, apesar de não haver significado estatístico, observou-se que a altura facial anterior aumentou mais nos grupos sem extração em comparação aos grupos com extração, porém não o suficiente para diminuir tal medida (AFP/AFA). 
TABELA 5.11 - Comparação entre os quatro grupos das alterações médias obtidas durante o tratamento (ANOVA)

\begin{tabular}{|c|c|c|c|c|c|c|c|c|c|c|}
\hline MEDID $A$ & $X f-X i 1$ & D.P. & $X f-X i 2$ & D.P. & $X f-X i 3$ & D.P. & $X f-X i 4$ & D.P. & $p$ & SIG. \\
\hline FMA(graus) & $-0,43$ & 2,09 & 0,17 & 3,40 & $-0,65$ & 2,81 & $-0,76$ & 2,31 & 0,78 & n.s. \\
\hline SN.GoGn(graus) & $-0,82$ & 2,04 & 0,80 & 2,65 & $-1,07$ & 2,53 & $-0,40$ & 2,14 & 0,15 & n.s. \\
\hline CMS-Franc(mm) & 3,62 & 2,51 & 2,75 & 1,89 & 3,18 & 2,46 & 2,99 & 2,47 & 0,77 & n.s. \\
\hline CMS-PP(mm) & 2,06 & 1,64 & 1,59 & 1,69 & 1,40 & 1,50 & 1,46 & 1,27 & 0,64 & n.s. \\
\hline CMI-PM(mm) & 2,05 & 2,00 & 2,04 & 2,20 & 2,75 & 1,67 & 1,94 & 1,60 & 0,64 & n.s. \\
\hline DMS-PTV(mm) & 3,92 & 1,95 & 2,11 & 4,03 & 3,03 & 2,47 & 1,26 & 2,65 & 0,08 & n.s. \\
\hline DMI-PTV(mm) & 3,85 & 1,93 & 2,38 & 3,94 & 4,26 & 2,53 & 2,77 & 2,42 & 0,23 & n.s. \\
\hline PFH(mm) & 3,14 & 2,72 & 2,46 & 2,51 & 3,51 & 2,20 & 3,10 & 2,59 & 0,72 & n.s. \\
\hline $\operatorname{AFH}(\mathbf{m m})$ & 2,82 & 2,58 & 3,55 & 2,71 & 2,61 & 2,29 & 3,54 & 2,10 & 0,62 & n.s. \\
\hline Horn(\%) & 2,14 & 3,93 & $-0,05$ & 3,21 & 3,00 & 4,10 & 0,99 & 3,32 & 0,13 & n.s. \\
\hline $\operatorname{AFP}(\mathbf{m m})$ & 4,11 & 3,37 & 3,84 & 2,77 & 4,88 & 2,69 & 4,71 & 3,45 & 0,77 & n.s. \\
\hline $\operatorname{AFA}(\mathbf{m m})$ & 1,02 & 1,82 & 0,02 & 1,85 & 1,66 & 2,04 & 0,88 & 1,70 & 0,13 & n.s. \\
\hline $\operatorname{AFP} / \mathbf{A F A}(\%)$ & 4,52 & 3,81 & 5,97 & 4,38 & 4,60 & 2,90 & 5,66 & 4,29 & 0,66 & n.s. \\
\hline AFAS(mm) & 2,14 & 2,69 & 2,72 & 2,77 & 2,27 & 1,58 & 2,46 & 3,06 & 0,93 & n.s. \\
\hline AFAI(mm) & 2,45 & 2,42 & 3,30 & 2,84 & 2,31 & 2,34 & 3,34 & 2,05 & 0,53 & n.s. \\
\hline AFAI/AFA(\%) & $-0,22$ & 1,57 & $-0,12$ & 1,53 & $-0,17$ & 1,23 & 0,02 & 1,48 & 0,97 & n.s. \\
\hline AFAI/AFAS(\%) & $-0,95$ & 8,73 & $-0,70$ & 8,96 & $-0,61$ & 6,01 & 0,66 & 8,07 & 0,94 & n.s. \\
\hline AFAS/AFA(\%) & 0,15 & 1,58 & 0,02 & 1,56 & 0,17 & 1,25 & $-0,12$ & 1,41 & 0,93 & n.s. \\
\hline
\end{tabular}




\subsection{CORRELAÇÃO ENTRE AS MEDIDAS CEFALOMÉTRICAS ESTUDADAS}

Nesta parte do estudo, analisaram-se as possíveis correlações entre as medidas angulares FMA e SN.GoGn e as alturas faciais anterior, posterior e as medidas dentoalveolares CMS-Franc, CMS-PP e CMI-PM nos quatro grupos (Tabelas 5.12 a 5.15). Avaliaram-se também as possíveis correlações entre a altura facial anterior e as medidas lineares dentoalveolares CMSFranc, CMS-PP, CMI-PM, DMS-PTV e DMI-PTV (Tabelas 5.16 a 5.19). 
TABELA 5.12 - Coeficiente de correlação de Pearson para verificar a correlação entre as alterações das medidas FMA, SN.GoGn e PFH, AFH, PFH/AFH, AFP, AFA, AFP/AFA, CMS-Franc, CMS-PP, CMI-PM para o Grupo I

\begin{tabular}{|c|c|c|c|c|}
\hline VARIÁVEL & r (FMA) & r(SN.GoGn) & P(FMA) & p(SN.GoGn) \\
\hline CMS-Franc & 0,41 & $-0,32$ & 0,12 & 0,23 \\
CMS-PP & 0,30 & 0,04 & 0,27 & 0,87 \\
CMI-PM & 0,12 & 0,04 & 0,65 & 0,88 \\
PFH & $-0,29$ & $-0,28$ & 0,28 & 0,30 \\
AFH & 0,36 & 0,22 & 0,18 & 0,42 \\
HORN & $-0,58$ & $-0,48$ & 0,02 & 0,06 \\
AFP & $-0,18$ & $-0,38$ & 0,52 & 0,15 \\
AFA & 0,13 & 0,22 & 0,62 & 0,42 \\
AFP/AFA & $-0,45$ & $-0,91$ & 0,09 & 0,00 \\
AFAI & 0,33 & 0,16 & 0,21 & 0,55 \\
\hline
\end{tabular}

$\mathrm{p} \leq 0,05$ : significante

TABELA 5.13 - Coeficiente de correlação de Pearson para verificar a correlação entre as alterações das medidas FMA, SN.GoGn e PFH, AFH, PFH/AFH, AFP, AFA, AFP/AFA, CMS-Franc, CMS-PP, CMI-PM para o Grupo II

\begin{tabular}{|c|c|c|c|c|}
\hline VARIÁVEL & $\mathrm{r}$ (FMA) & $\mathrm{r}$ (SN.GoGn) & $\mathrm{p}$ (FMA) & $\mathrm{p}$ (SN.GoGn) \\
\hline CMS-Franc & 0,33 & $-0,14$ & 0,22 & 0,59 \\
CMS-PP & 0,07 & $-0,12$ & 0,78 & 0,65 \\
CMI-PM & $-0,48$ & 0,22 & 0,06 & 0,41 \\
PFH & $-0,41$ & $-0,11$ & 0,12 & 0,68 \\
AFH & $-0,16$ & 0,20 & 0,54 & 0,45 \\
HORN & $-0,39$ & $-0,29$ & 0,14 & 0,27 \\
AFP & $-0,57$ & $-0,08$ & 0,02 & 0,75 \\
AFA & $-0,37$ & 0,60 & 0,16 & 0,01 \\
AFP/AFA & $-0,30$ & $-0,92$ & 0,27 & 0,00 \\
AFAI & $-0,31$ & 0,21 & 0,25 & 0,44 \\
\hline
\end{tabular}


TABELA 5.14 - Coeficiente de correlação de Pearson para verificar a correlação entre as alterações das medidas FMA, SN.GoGn e PFH, AFH, PFH/AFH, AFP, AFA, AFP/AFA, CMS-Franc, CMS-PP, CMI-PM para o Grupo III

\begin{tabular}{|c|c|c|c|c|}
\hline VARIÁVEL & $\mathrm{r}$ (FMA) & $\mathrm{r}$ (SN.GoGn) & $\mathrm{p}$ (FMA) & $\mathrm{p}$ (SN.GoGn) \\
\hline CMS-Franc & 0,57 & 0,22 & 0,03 & 0,44 \\
CMS-PP & 0,55 & 0,54 & 0,04 & 0,04 \\
CMI-PM & 0,19 & $-0,03$ & 0,50 & 0,90 \\
PFH & $-0,39$ & $-0,71$ & 0,16 & 0,04 \\
AFH & 0,43 & 0,41 & 0,12 & 0,13 \\
HORN & $-0,64$ & $-0,90$ & 0,01 & 0,00 \\
AFP & $-0,21$ & $-0,58$ & 0,46 & 0,02 \\
AFA & 0,48 & 0,38 & 0,07 & 0,17 \\
AFP/AFA & $-0,62$ & $-0,96$ & 0,01 & 0,00 \\
AFAI & 0,42 & 0,51 & 0,12 & 0,06 \\
\hline
\end{tabular}

$\mathrm{p} \leq 0,05$ : significante

TABELA 5.15 - Coeficiente de correlação de Pearson para verificar a correlação entre as alterações das medidas FMA, SN.GoGn e PFH, AFH, PFH/AFH, AFP, AFA, AFP/AFA, CMS-Franc, CMS-PP, CMI-PM para o Grupo IV

\begin{tabular}{|c|c|c|c|c|}
\hline VARIÁVEL & $\mathrm{r}$ (FMA) & $\mathrm{r}$ (SN.GoGn) & $\mathrm{p}$ (FMA) & $\mathrm{p}$ (SN.GoGn) \\
\hline CMS-Franc & 0,10 & $-0,03$ & 0,71 & 0,89 \\
CMS-PP & $-0,01$ & 0,00 & 0,94 & 0,97 \\
CMI-PM & $-0,00$ & $-0,01$ & 0,97 & 0,95 \\
PFH & $-0,38$ & $-0,35$ & 0,15 & 0,19 \\
AFH & 0,14 & 0,05 & 0,60 & 0,85 \\
HORN & $-0,62$ & $-0,53$ & 0,01 & 0,04 \\
AFP & $-0,26$ & $-0,30$ & 0,34 & 0,26 \\
AFA & 0,05 & 0,25 & 0,83 & 0,35 \\
AFP/AFA & $-0,54$ & $-0,92$ & 0,03 & 0,00 \\
AFAI & 0,18 & 0,10 & 0,51 & 0,70 \\
\hline
\end{tabular}


TABELA 5.16 - Coeficiente de correlação de Pearson para verificar a correlação entre as alterações da altura facial anterior e as medidas lineares dentoalveolares CMS-Franc, CMS-PP, CMI-PM, DMS-PTV e DMI-PTV para o Grupo I

\begin{tabular}{|c|c|c|c|c|}
\hline VARIÁVEL & r (AFAI) & r(AFA) & p(AFAI) & p(AFA) \\
\hline CMS-Franc & 0,47 & 0,51 & 0,07 & 0,04 \\
CMS-PP & 0,68 & 0,65 & 0,00 & 0,00 \\
CMI-PM & 0,70 & 0,72 & 0,00 & 0,00 \\
DMS-PTV & 0,23 & 0,14 & 0,40 & 0,59 \\
DMI-PTV & 0,26 & 0,18 & 0,33 & 0,50 \\
\hline
\end{tabular}

$\mathrm{p} \leq 0,05$ : significante

TABELA 5.17 - Coeficiente de correlação de Pearson para verificar a correlação entre as alterações da altura facial anterior e as medidas lineares dentoalveolares CMS-Franc, CMS-PP, CMI-PM, DMS-PTV e DMI-PTV para o Grupo II

\begin{tabular}{|c|c|c|c|c|}
\hline VARIÁVEL & $\mathrm{r}(\mathrm{AFAI})$ & $\mathrm{r}(\mathrm{AFA})$ & $\mathrm{p}(\mathrm{AFAI})$ & $\mathrm{p}(\mathrm{AFA})$ \\
\hline CMS-Franc & 0,37 & 0,15 & 0,16 & 0,57 \\
CMS-PP & 0,51 & 0,27 & 0,06 & 0,31 \\
CMI-PM & 0,83 & 0,85 & 0,00 & 0,00 \\
DMS-PTV & 0,65 & 0,71 & 0,00 & 0,00 \\
DMI-PTV & 0,63 & 0,71 & 0,01 & 0,00 \\
\hline
\end{tabular}


TABELA 5.18 - Coeficiente de correlação de Pearson para verificar a correlação entre as alterações da altura facial anterior e as medidas lineares dentoalveolares CMS-Franc, CMS-PP, CMI-PM, DMS-PTV e DMI-PTV para o Grupo III

\begin{tabular}{|c|c|c|c|c|}
\hline VARIÁVEL & r (AFAI) & r(AFA) & p(AFAI) & P(AFA) \\
\hline CMS-Franc & 0,33 & 0,56 & 0,23 & 0,03 \\
CMS-PP & 0,57 & 0,68 & 0,03 & 0,00 \\
CMI-PM & 0,64 & 0,58 & 0,01 & 0,02 \\
DMS-PTV & 0,35 & 0,51 & 0,21 & 0,06 \\
DMI-PTV & 0,32 & 0,50 & 0,25 & 0,06 \\
\hline
\end{tabular}

$\mathrm{p} \leq 0,05$ : significante

TABELA 5.19 - Coeficiente de correlação de Pearson para verificar a correlação entre as alterações da altura facial anterior e as medidas lineares dentoalveolares CMS-Franc, CMS-PP, CMI-PM, DMS-PTV e DMI-PTV para o Grupo IV

\begin{tabular}{|c|c|c|c|c|}
\hline VARIÁVEL & r (AFAI) & r(AFA) & p(AFAI) & P(AFA) \\
\hline CMS-Franc & 0,86 & 0,77 & 0,00 & 0,00 \\
CMS-PP & 0,48 & 0,28 & 0,06 & 0,31 \\
CMI-PM & 0,73 & 0,66 & 0,00 & 0,00 \\
DMS-PTV & 0,15 & 0,00 & 0,57 & 0,98 \\
DMI-PTV & 0,07 & $-0,07$ & 0,78 & 0,80 \\
\hline
\end{tabular}




\section{FMA}

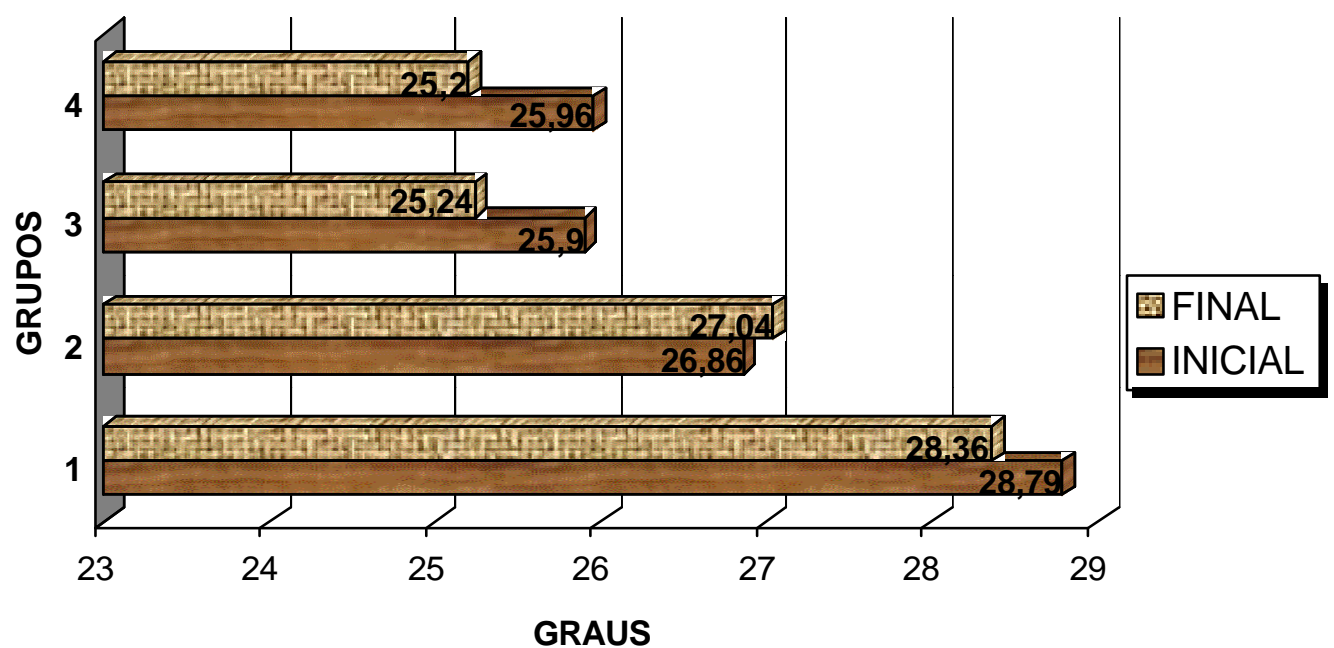

FIGURA 5.1 - Angulação do plano mandibular em relação ao plano de Francfort. Valores médios iniciais e finais para cada grupo.

\section{SN.GoGn}
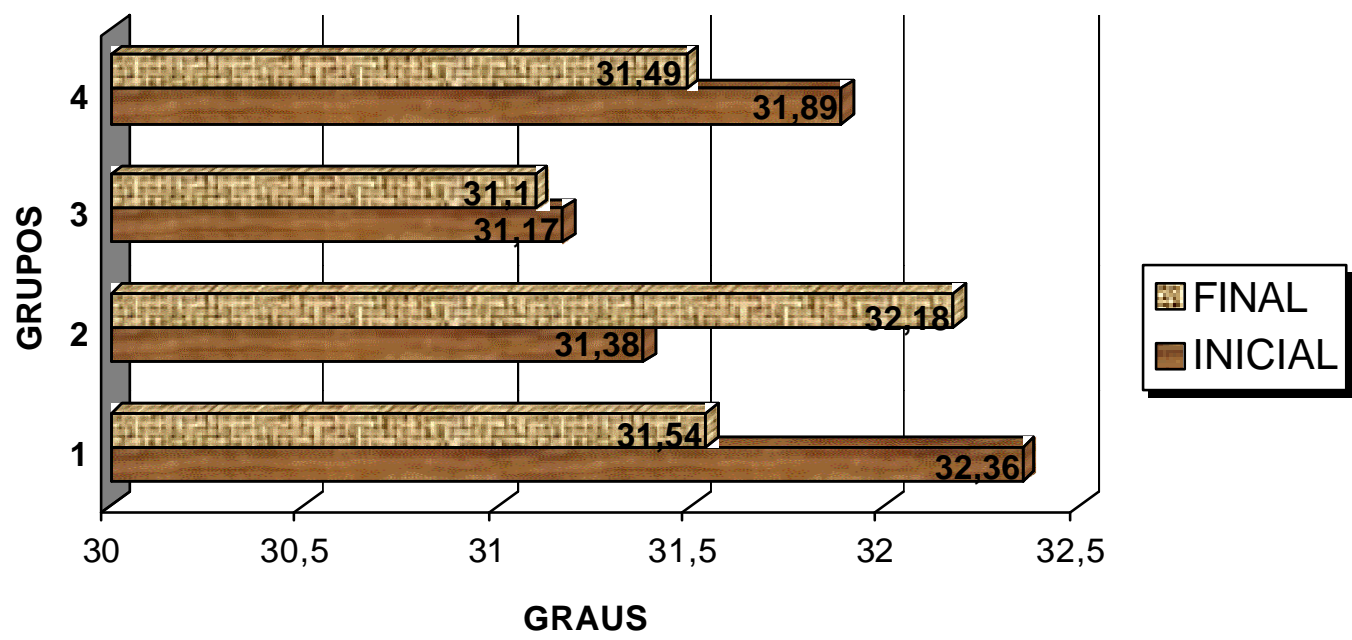

FIGURA 5.2 - Angulação do plano mandibular em relação à base do crânio. Valores médios iniciais e finais para cada grupo. 


\section{CMS-Franc}

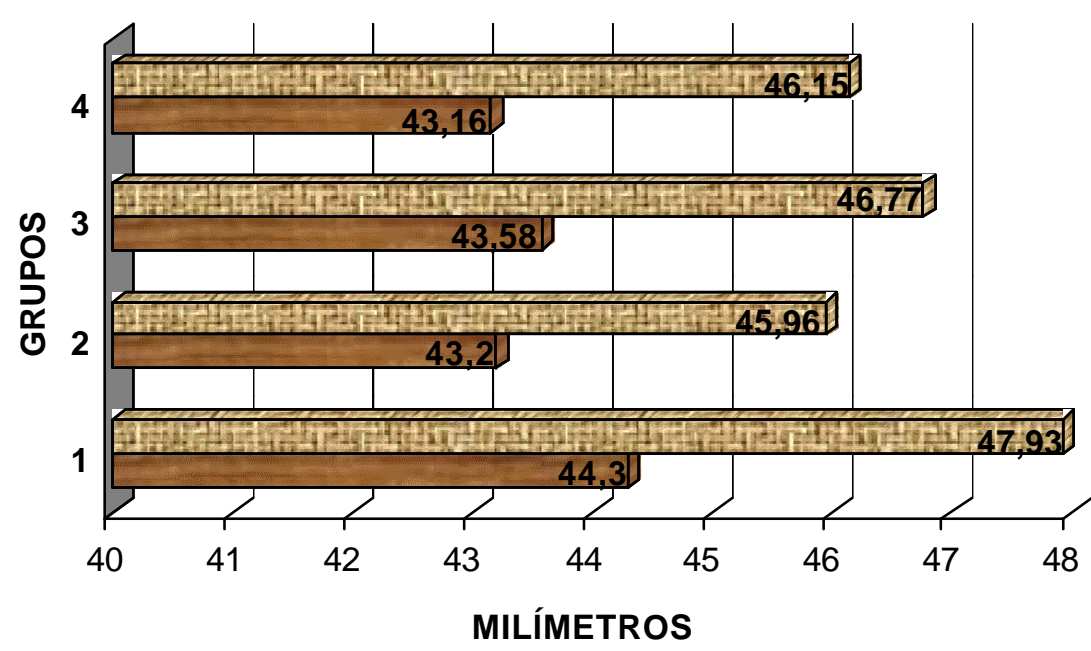

FIGURA 5.3 - Distância entre a ponta de cúspide mesial do primeiro molar superior permanente e o Plano de Francfort. Valores médios iniciais e finais para cada grupo.

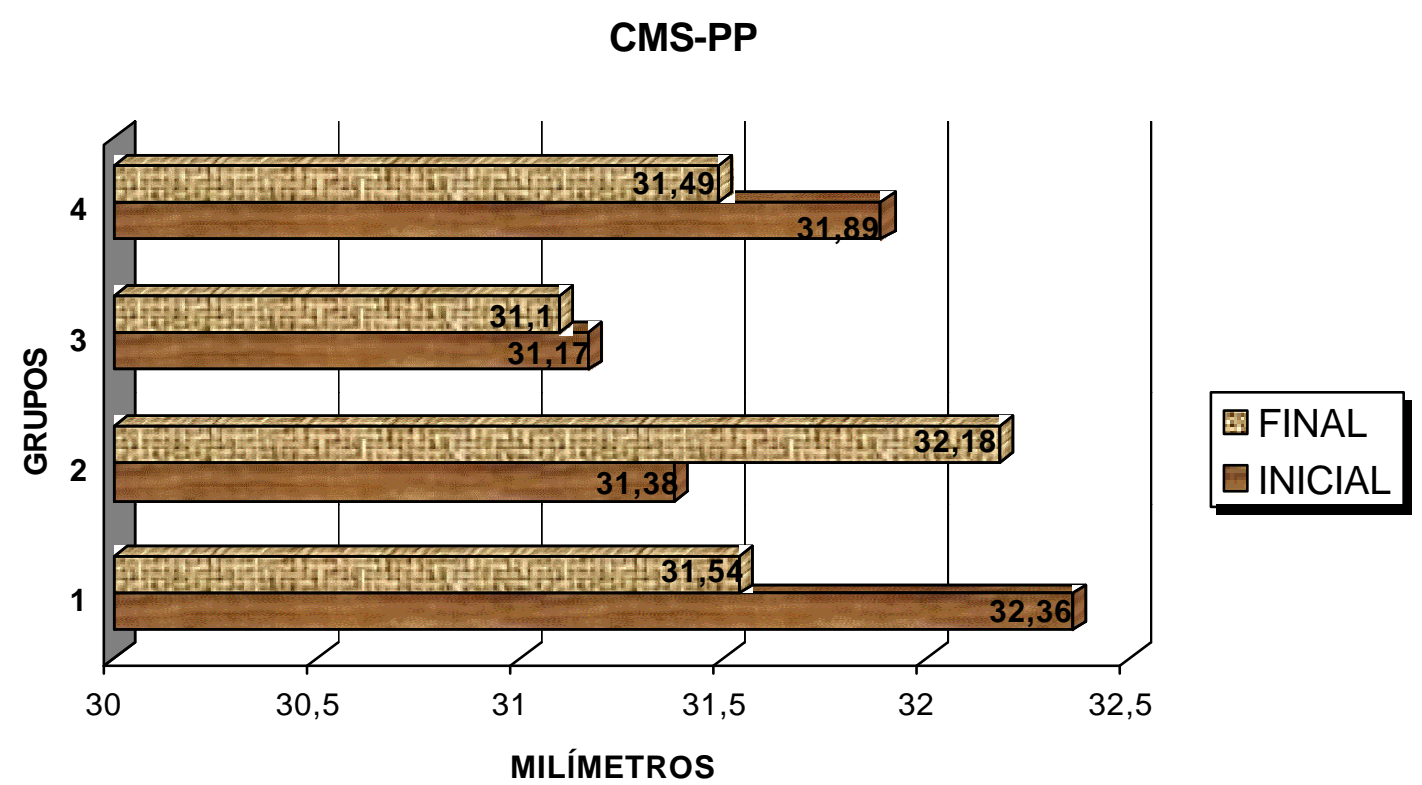

FIGURA 5.4 - Distância entre a ponta de cúspide mesial do primeiro molar superior permanente e o plano palatino. Valores médios iniciais e finais para cada grupo. 


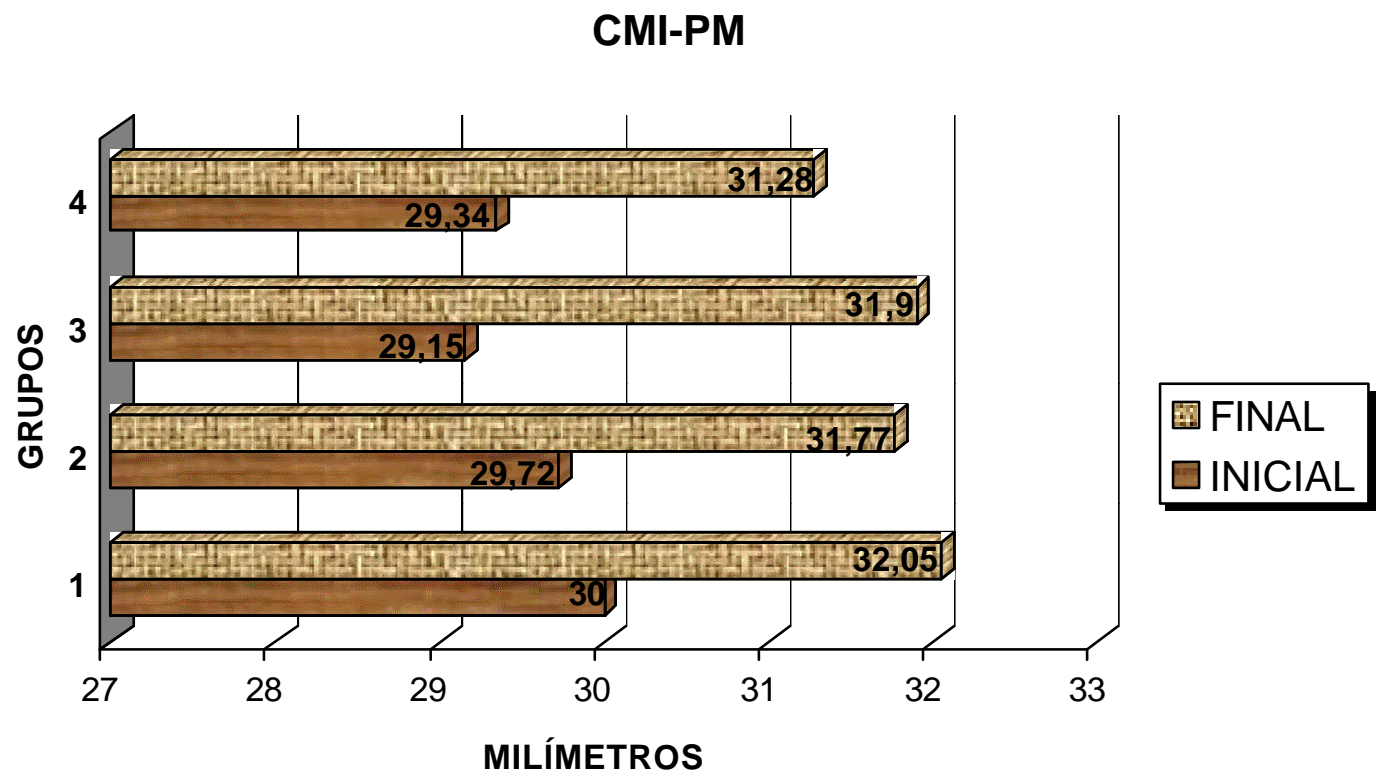

FIGURA 5.5 - Distância entre a ponta de cúspide mesial do primeiro molar inferior permanente e o Plano Mandibular. Valores médios iniciais e finais para cada grupo.

\section{DMS-PTV}

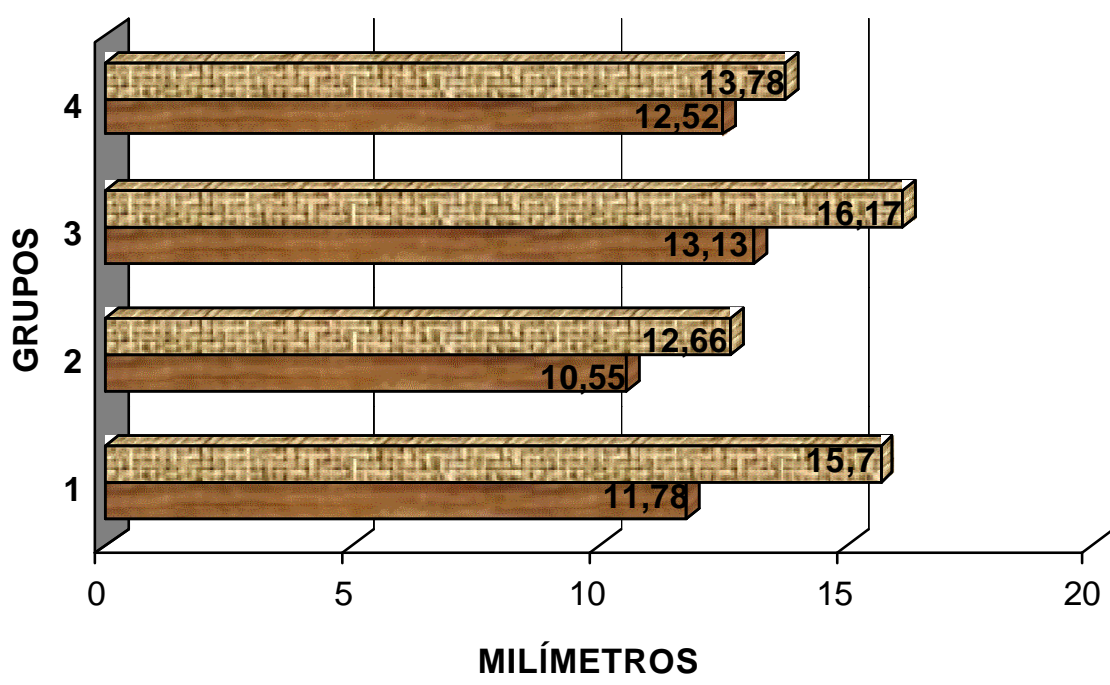

FIGURA 5.6- Distância horizontal entre a face distal do primeiro molar superior permanente e a linha PTV. Valores médios iniciais e finais para cada grupo. 


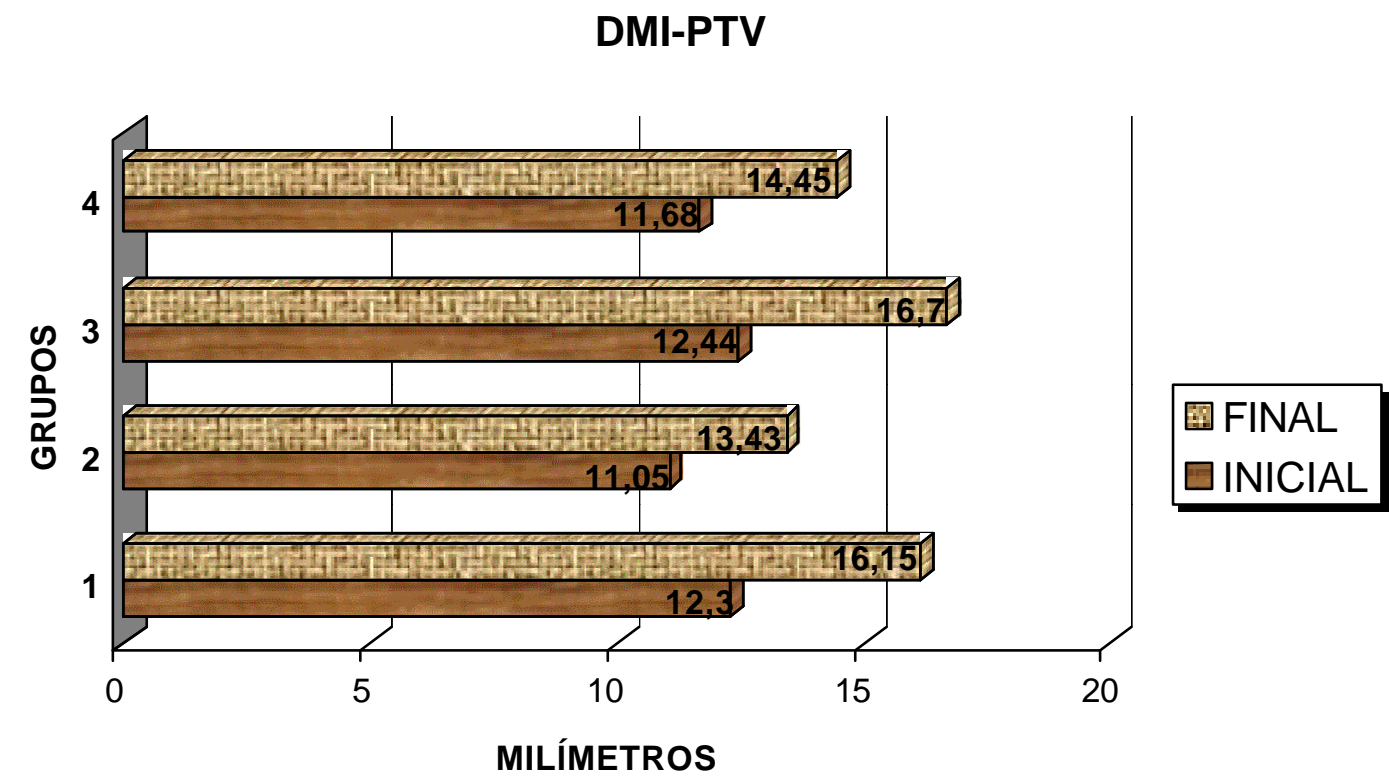

FIGURA 5.7 - Distância horizontal entre a face distal do primeiro molar inferior permanente e a linha PTV. Valores médios iniciais e finais para cada grupo

\section{PFH}

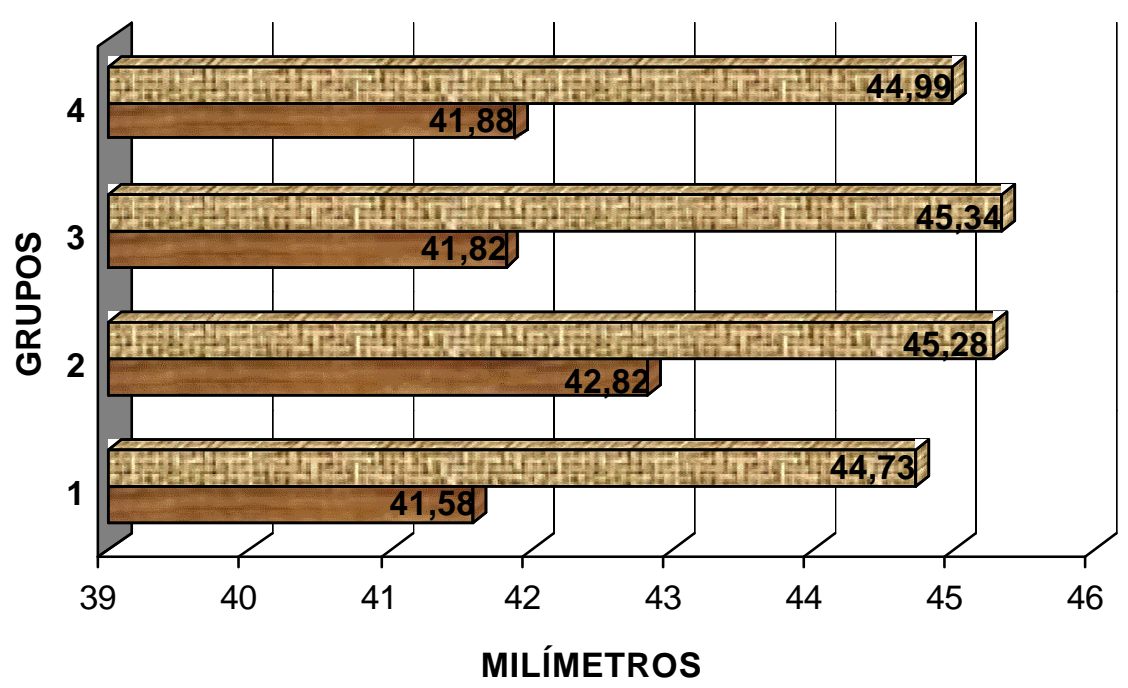

圆 FINAL

$\square$ INICIAL

FIGURA 5.8 - Altura facial póstero-inferior. Valores médios iniciais e finais para cada grupo 


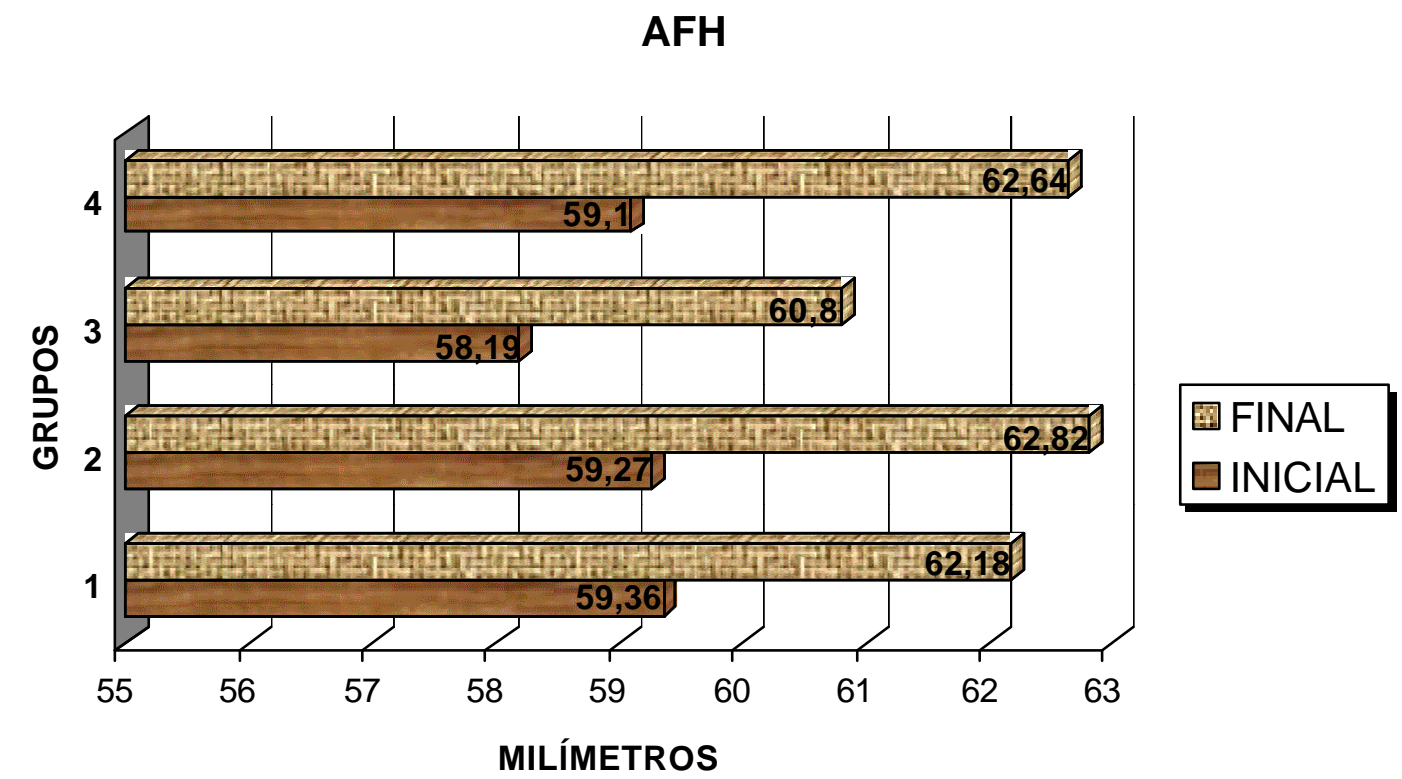

FIGURA 5.9 - Altura facial ântero-inferior segundo GEBECK \& MERRIFIELD ${ }^{75,76}$. Valores médios iniciais e finais para cada grupo

HORN

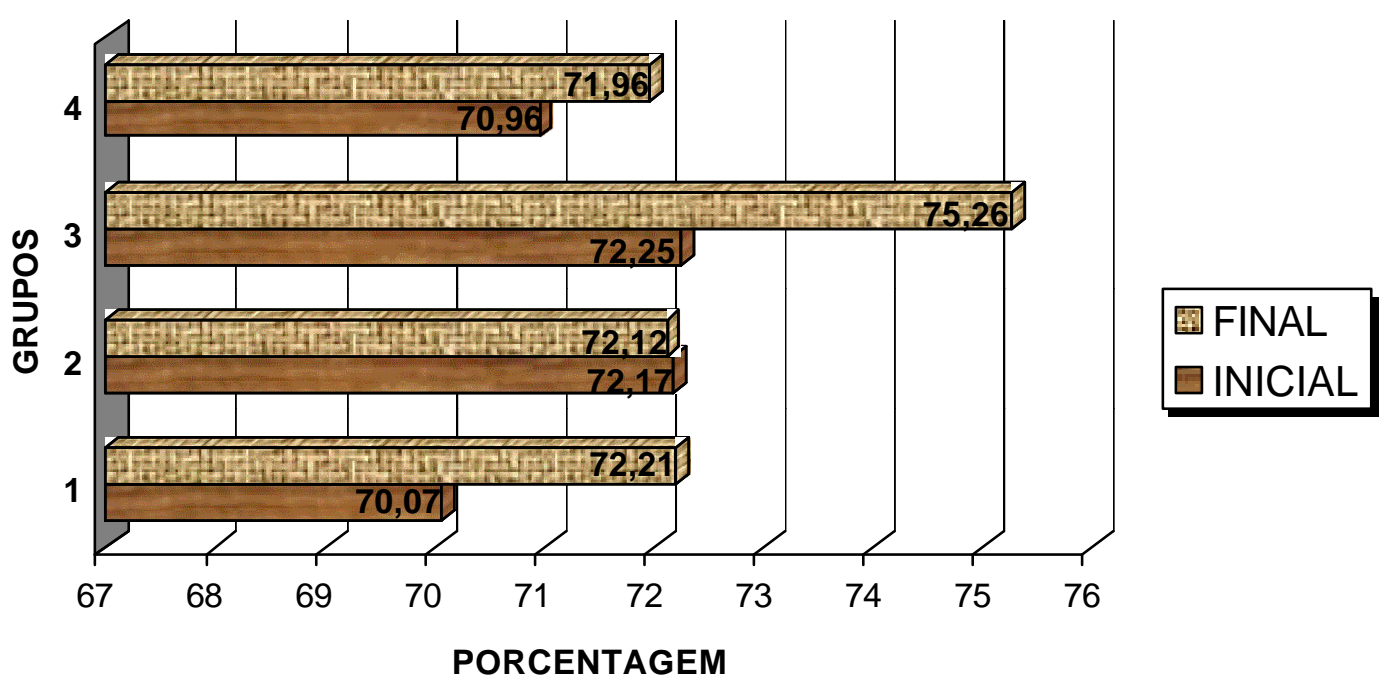

FIGURA 5.10 - Índice de HORN ${ }^{91}$. Proporção entre a medida PFH e a medida AFH. Valores médios iniciais e finais para cada grupo 


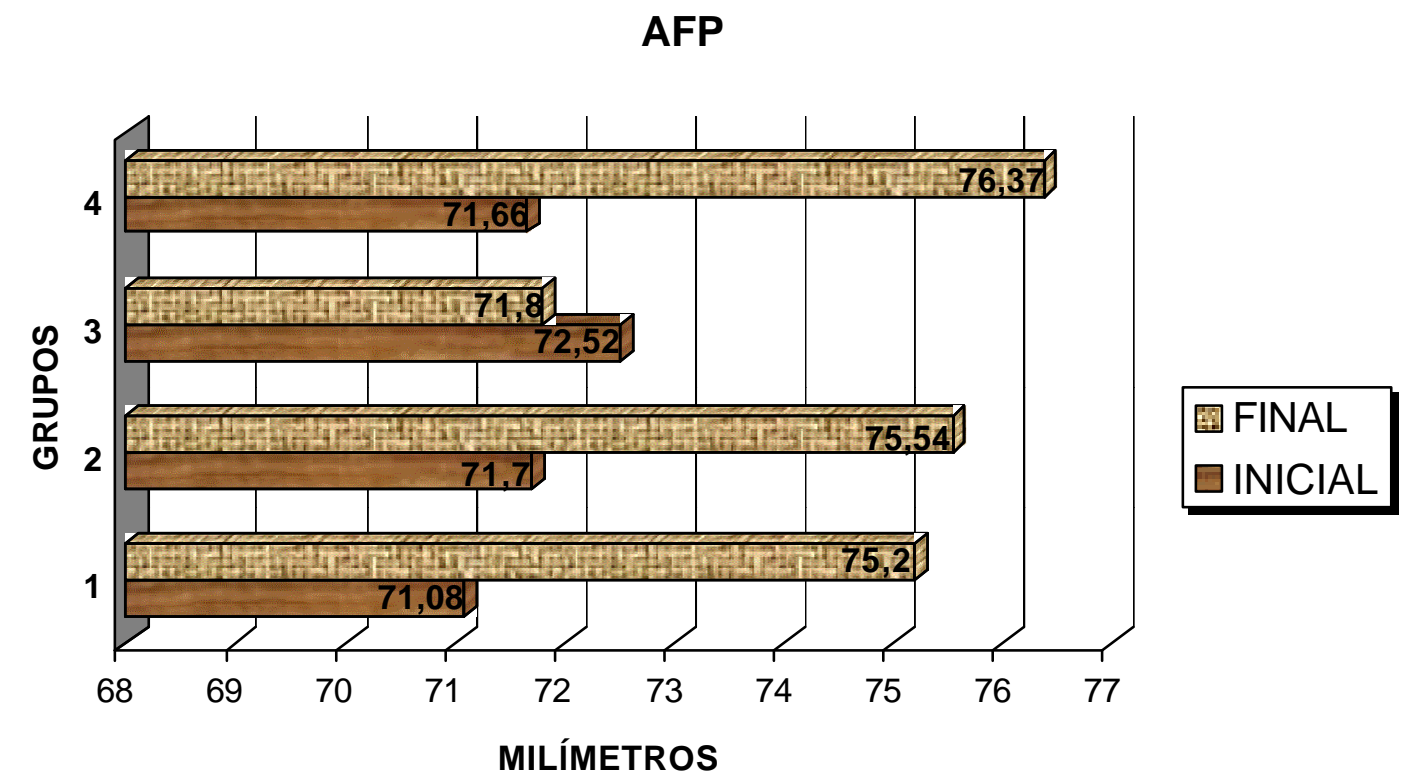

FIGURA 5.11 - Altura facial posterior total. Valores médios iniciais e finais para cada grupo

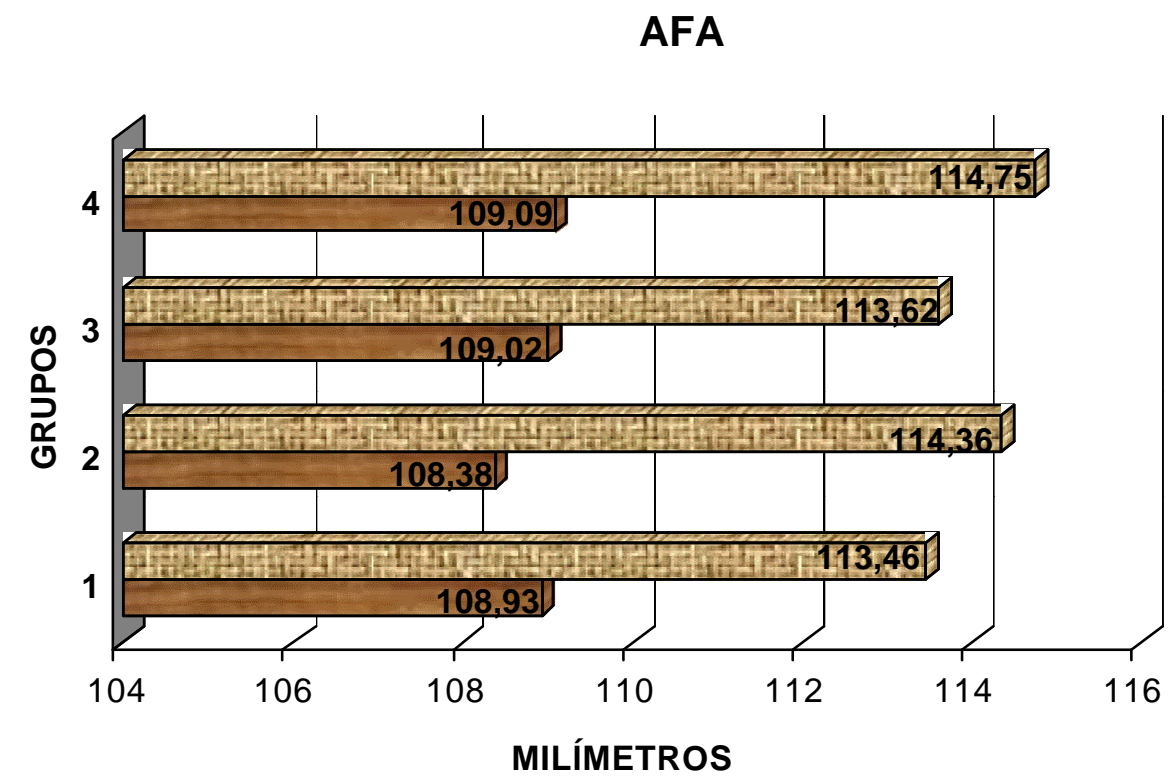
圆FINAL
$\square$ INICIAL

FIGURA 5.12 - Altura facial anterior total. Valores médios iniciais e finais para cada grupo 


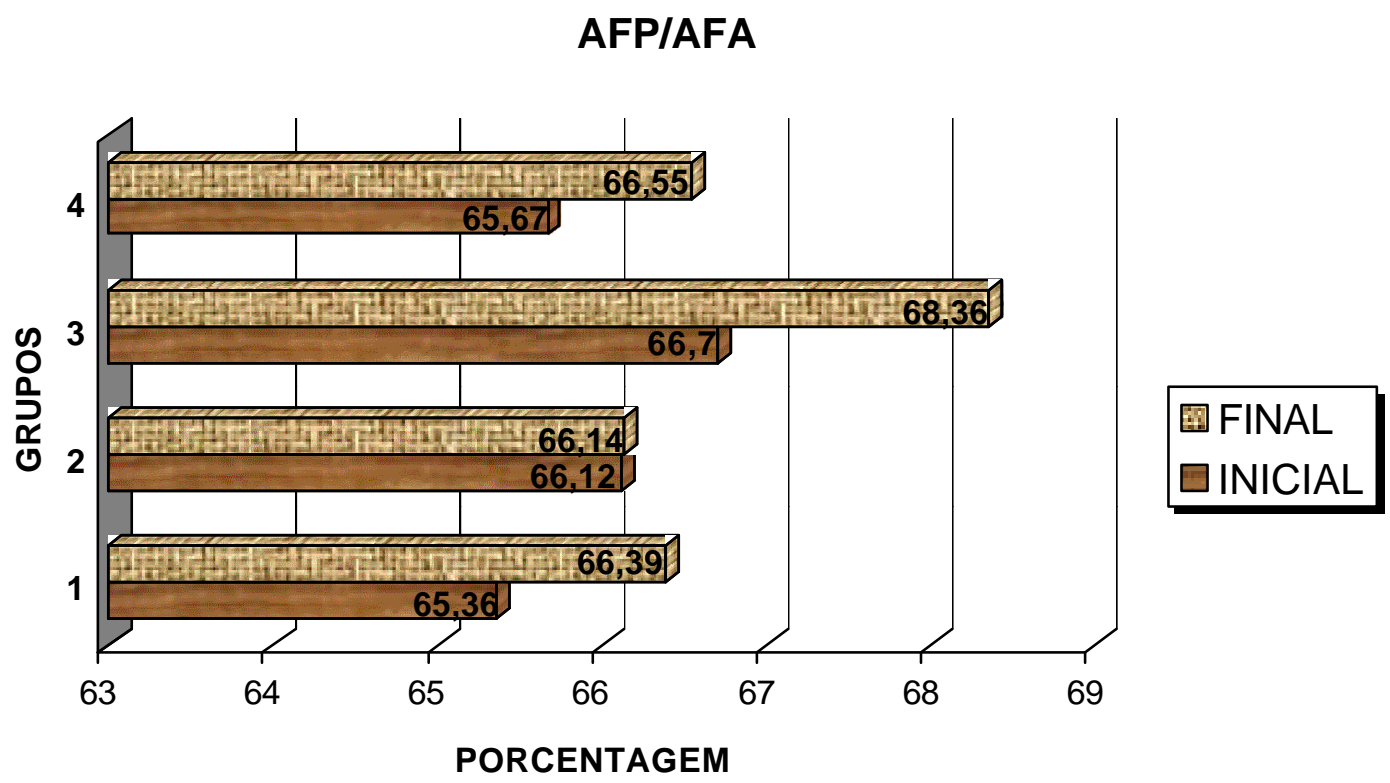

FIGURA 5.13 - Quociente de Jarabak. Proporção entre a altura facial posterior total e a altura facial anterior total. Valores médios iniciais e finais para cada grupo

\section{AFAS}

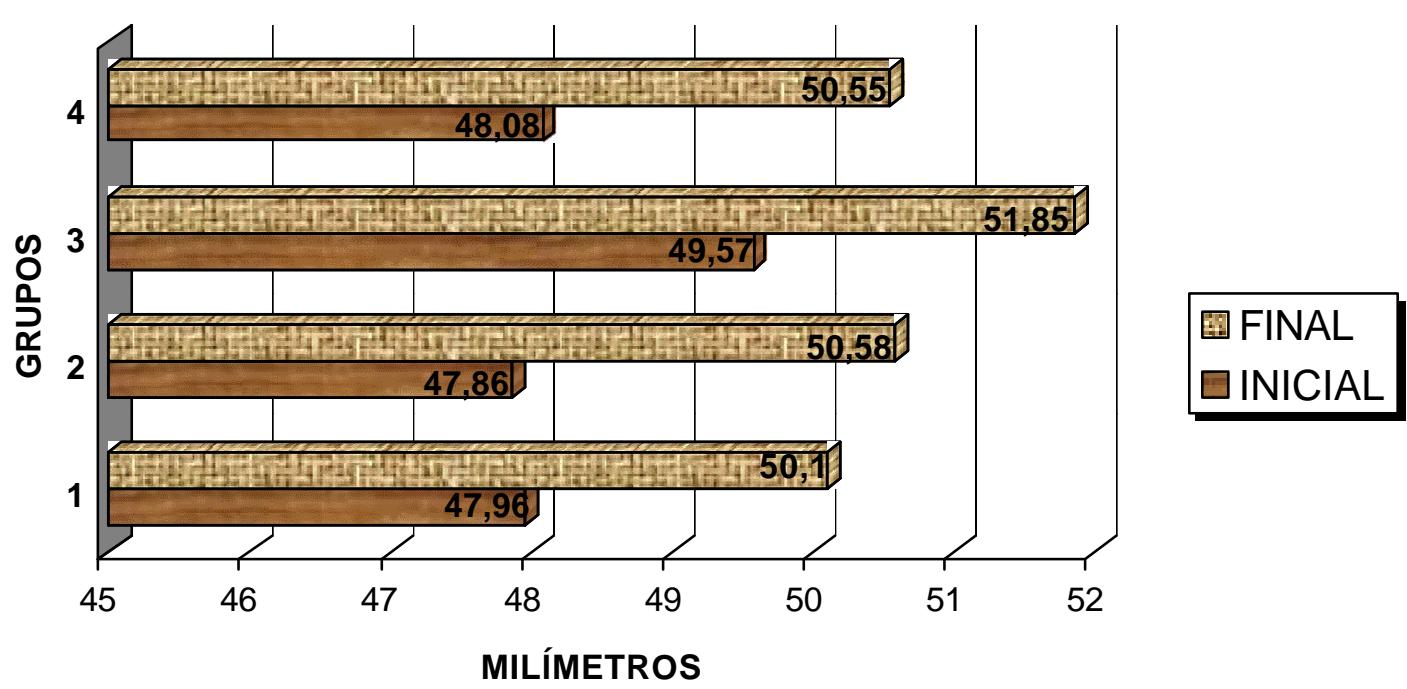

FIGURA 5.14 - Altura facial ântero-superior. Valores médios iniciais e finais para cada grupo 


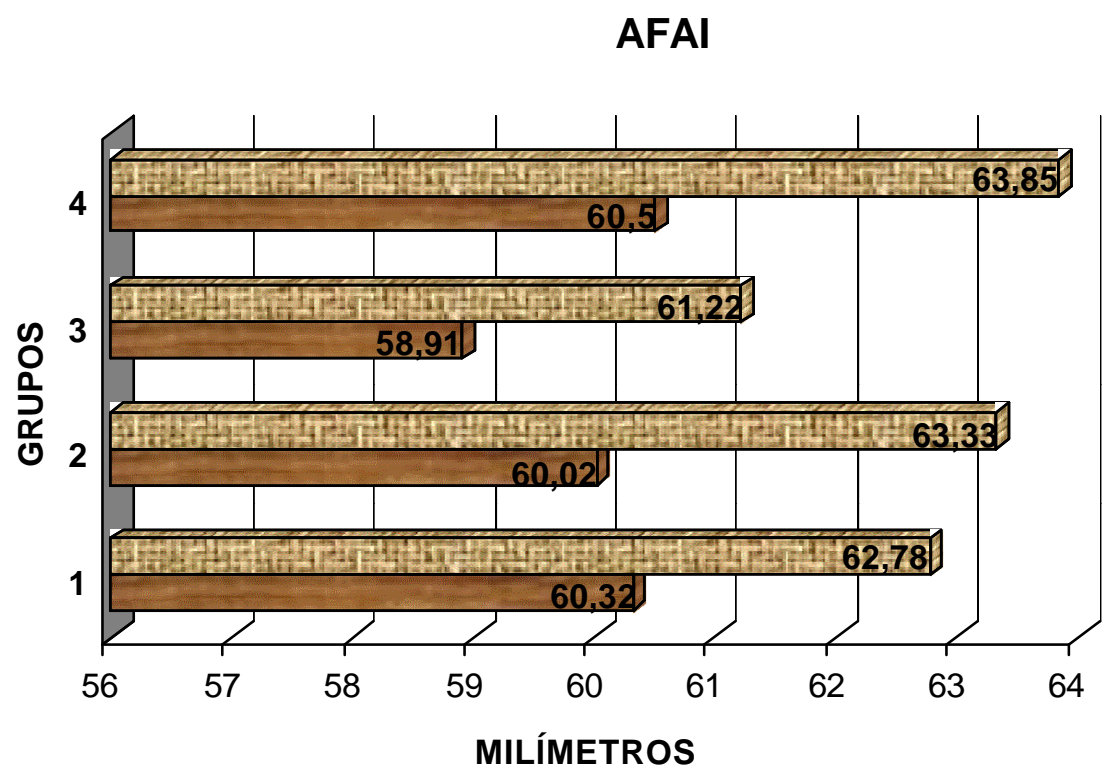

FIGURA 5.15 - Altura facial ântero-inferior. Valores médios iniciais e finais para cada grupo

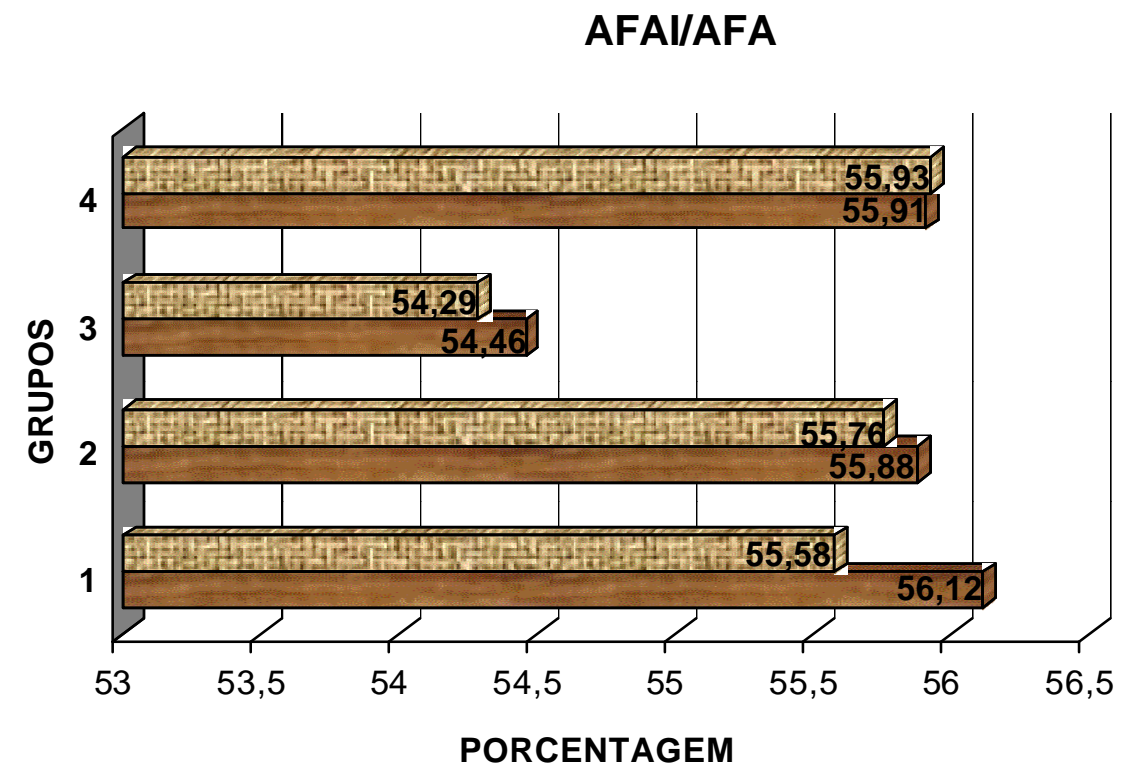

FIGURA 5.16 - Proporção entre a altura facial antero-inferior e a altura facial anterior total. Valores médios iniciais e finais para cada grupo 


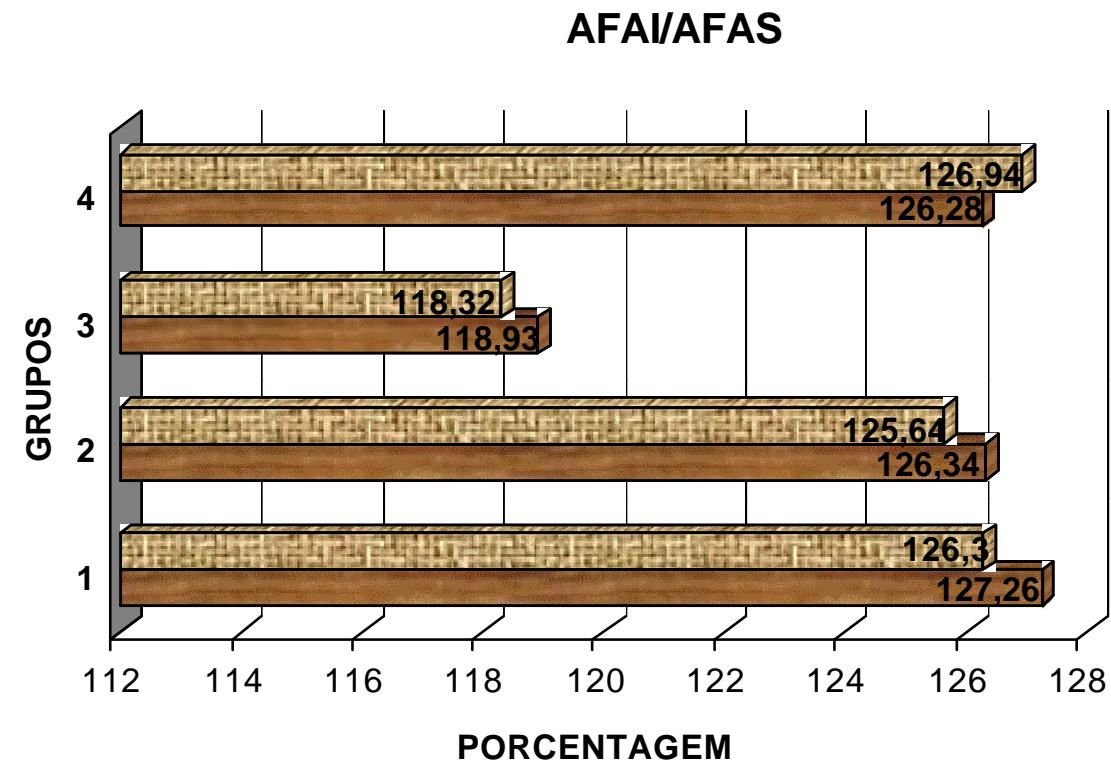

FIGURA 5.17 - Proporção entre a altura facial ântero-inferior e a altura facial anterosuperior. Valores médios iniciais e finais para cada grupo

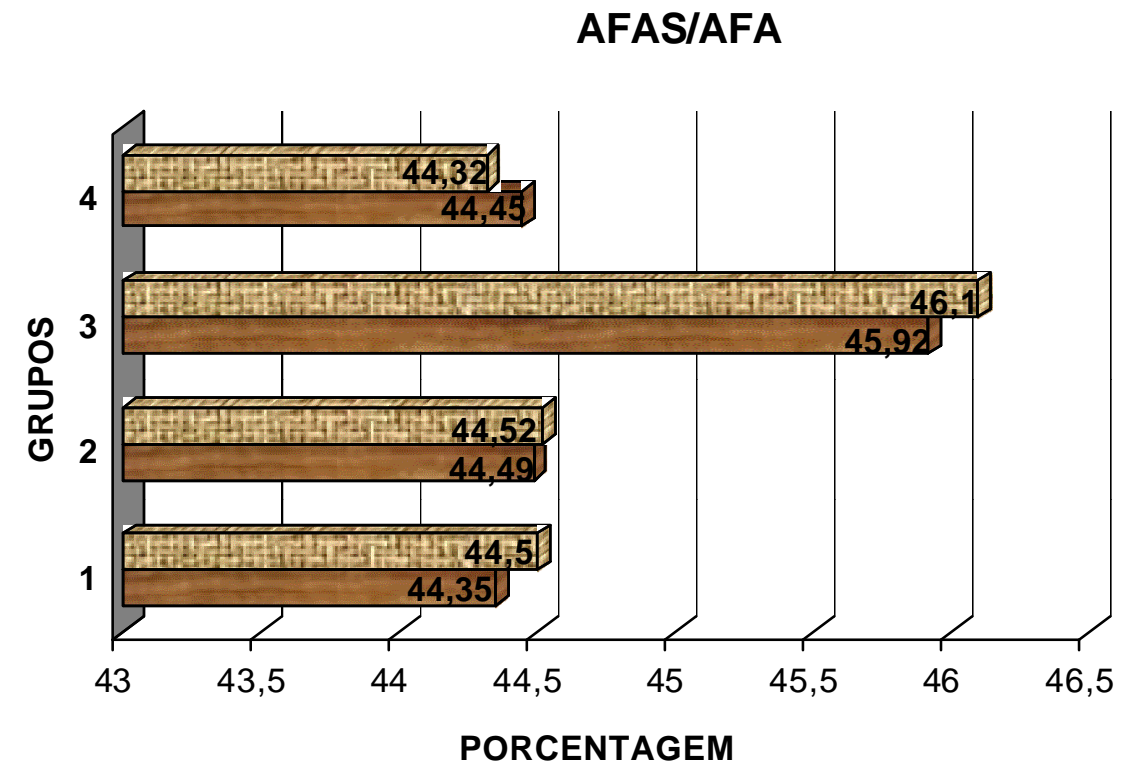

FIGURA 5.18 - Proporção entre a altura facial ântero-superior e a altura facial anterior total. Valores médios iniciais e finais para cada grupo 


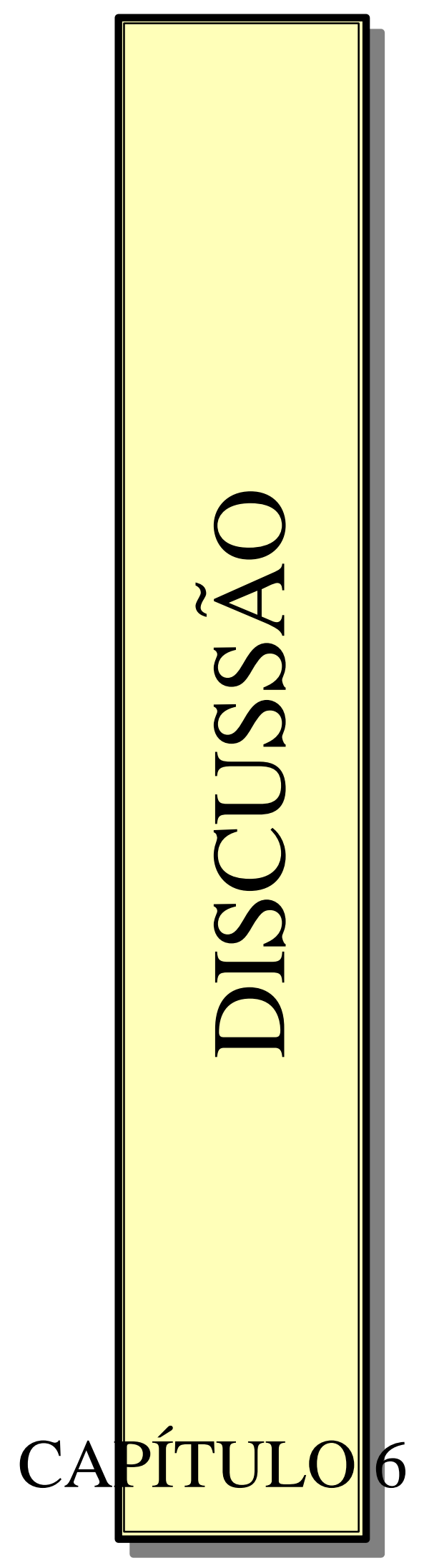




\section{DISCUSSÃO}

A obtenção da estética facial constitui um dos principais objetivos do tratamento ortodôntico, além de ser um requisito extremamente fundamental para a satisfação do paciente. Para isso, deve haver equilíbrio e harmonia do complexo craniofacial nos sentidos horizontal, transversal e vertical ${ }^{7,17,146,176}$.

Muitas más oclusões ântero-posteriores são decorrentes de um desenvolvimento vertical anormal ou são agravadas pelo mesmo. Na Classe II, $1^{\text {a }}$ divisão, por exemplo, quanto mais a altura facial anterior se desenvolver em relação à altura facial posterior, maior será a rotação mandibular no sentido horário, tornando o perfil facial mais convexo ${ }^{27,41,58,75,76,91,119,153,178,183}$.

Embora o equilíbrio e a harmonia da face humana não recebam influência apenas das alturas faciais e de suas proporções, é de suma importância que o ortodontista possua o conhecimento dos padrões de normalidade, para que assim ele possa reconhecer mais facilmente as anormalidades do complexo craniofacial ${ }^{8,10,44,50,63,121,123}$.

A estética e a harmonia não são conceitos fixos e os padrões de beleza variam apreciavelmente de pessoa para pessoa, entre as diferentes etnias, além de serem influenciados pelo padrão sócio-econômico-cultural ${ }^{54}$. Assim, pelo fato da estética ser um sentimento muito pessoal e subjetivo, a avaliação das proporções faciais é muito mais útil do que a avaliação estética por si só ${ }^{40,109}$.

Apesar do estudo das proporções faciais não ser recente nem tampouco escasso, sua interação com o processo de crescimento e desenvolvimento 


\section{Disaussão}

craniofacial foi alvo de muita discussão. Os primeiros trabalhos encontrados na literatura, desde o início do século XX, como os realizados por BROADBENT ${ }^{31}$, BRODIE $^{33}$, HERZBERG \& HOLIC ${ }^{89}$, WYLIE $^{214}$, TIRK $^{200}$, concentraram-se em demonstrar a "constância" do padrão de crescimento e a manutenção das proporções faciais. Em geral, estes autores relataram que tanto o padrão de crescimento quanto as proporções faciais são estabelecidos precocemente, permanecendo constantes até o final do crescimento. Porém, é extremamente perceptível que a face da criança não aumenta apenas em tamanho ao passar para a fase adulta. Assim, constatou-se que os padrões esquelético e dentário, bem como as proporções faciais anteriores estão sujeitos a alterações com o crescimento, principalmente durante a adolescência, segundo os trabalhos de $\operatorname{HELLMAN}^{82}$, ISAACSON ${ }^{97}$, $\mathrm{KROGMAN}^{113}$, BJÖRK ${ }^{25}, \mathrm{JOHNSON}^{103}, \mathrm{BAUM}^{11}, \mathrm{LANDE}^{116}, \mathrm{DOWNS}^{64}$, MEREDITH; KNOTT; HIXON $^{137}$; MOORE $^{143}, \quad$ GRABER $^{79}$,

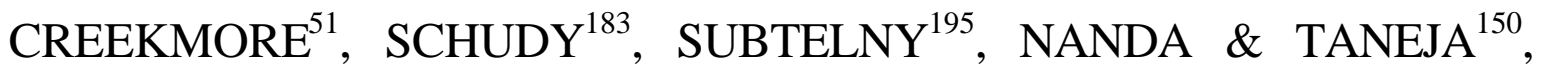
$\mathrm{CROSS}^{52}$, BISHARA et al. ${ }^{18}$, VAN DER BEEK et al. ${ }^{207}$, KERR \& LAN FORD $^{107}$, CLEALL; BEGOLE; CHEBIB $^{46}$; SCAVONE JR; FREITAS; HENRIQUES $^{179}$. MCNAIR ${ }^{133}$ verificou que o maior crescimento vertical ocorre entre as idades de 12 e 13 anos, no gênero masculino e entre os 11 e 12 anos no gênero feminino, ou seja, durante o pico de crescimento.

Os estudos sobre o crescimento vertical da face com oclusão normal afirmam que a altura facial posterior desenvolve-se mais que a anterior. ${ }^{25,82}$ Logo, é de se esperar que o tratamento ortodôntico idealmente produza efeitos semelhantes aos produzidos pela natureza, compensando os padrões faciais desfavoráveis à estética facial. 
Os resultados deste trabalho demonstraram uma harmonia com o processo de crescimento normal. Para um melhor desenvolvimento deste capítulo, as alterações dentoesqueléticas ocorridas durante o tratamento ortodôntico das Classes I e II, $1^{\text {a }}$ divisão com e sem extrações foram divididas em:

6.1- Medidas esqueléticas

6.2- Medidas dentoalveolares 


\section{1- Medidas esqueléticas}

Para um diagnóstico e um plano de tratamento ideais, é de suma importância a consideração do padrão de crescimento vertical, uma vez que muitas más oclusões ântero-posteriores são decorrentes de um desenvolvimento vertical anormal. ${ }^{119,178}$ Além disso, o padrão esquelético no sentido vertical constitui um fator que diferencia as más oclusões com um relacionamento dentário idêntico ${ }^{153}$, sendo, portanto, decisivo na escolha da abordagem terapêutica a ser utilizada.

Neste tópico, foram abordadas as alterações ocorridas durante o tratamento ortodôntico tanto nas medidas angulares como nas medidas lineares envolvidas diretamente com o padrão de crescimento facial, ou seja: FMA, SN.GoGn, PFH, AFH, HORN, AFP, AFA, AFP/AFA, AFA, AFAS, AFAI, AFAI/AFA, AFAI/AFAS e AFAS/AFA.

\subsubsection{FMA e SN.GoGn}

Inicialmente, os ângulos FMA e SN.GoGn foram utilizados neste estudo para uma melhor padronização da amostra, ou seja, foram selecionados apenas pacientes que apresentassem um padrão de crescimento equilibrado, com valores de FMA compreendidos entre 23,4 e 34,4 graus para o gênero feminino $(28,9 \pm 5,5)$ e entre 22,4 e 32,0 graus para o masculino $(27,2 \pm 4,8)$ ou SN.GoGn compreendidos entre os 27,3 e 39,1 graus para o gênero feminino $(33,2 \pm 5,9)$ e 26,4 e 35,2 graus para o masculino $(30,8 \pm 4,4)$. Estes valores correspondem aos preconizados por TAKAHASHI ${ }^{196}$, em 1998, para nipo-brasileiros com faces equilibradas. Embora autores como JANSON; 


\section{Disaussão}

WOODSIDE; METAXAS ${ }^{102}$ e DAINESI $^{57}$ tenham proposto a determinação do tipo facial pelo cálculo da proporção entre as alturas faciais anteriores, não se encontraram valores normais que pudessem ser aplicados aos nipobrasileiros. Assim, por esse motivo, decidiu-se utilizar as medidas FMA e SN.GoGn como parâmetros para a determinação do padrão facial, assim como vários outros autores os utilizaram para leucodermas, tais como DARENDELILER; TANER-SARISOY ${ }^{58}, \quad$ JOHNSON $^{103}, \quad$ SCHUDY $^{184}$, WYLIE \& JOHNSON ${ }^{216}$, ZAHER; BISHARA; JAKOBSEN ${ }^{220}$.

Uma vez utilizados para a determinação do padrão facial, estes ângulos foram analisados para se verificar se o tratamento ortodôntico com extrações os alteraria significantemente.

Os resultados obtidos para os valores de FMA e SN.GoGn não demonstraram alterações estatisticamente significantes durante o tratamento ortodôntico nos quatro grupos estudados e estão de acordo com os achados de BISHARA et $\mathrm{al}^{23}$, CAPELOZZA FILHO et $\mathrm{al}^{39}$, CUSIMANO et $\mathrm{al}^{53}$, KOCADERELLI $^{112}$, SANKEY et $\mathrm{al}^{174}$, STAGGERS ${ }^{193}$ e TANER-SARISOY; DARENDELILER $^{198}$ (Figura 6.1). A não alteração destes ângulos sugere que a mecânica ortodôntica foi condizente com o processo de crescimento dos pacientes, fato este muito importante, principalmente para os casos de Classe II, pois não houve uma rotação horária da mandíbula, o que pode ter favorecido a correção da má oclusão, além de proporcionar um perfil facial mais agradável.

Além da influência da mecânica ortodôntica, deve-se levar em consideração também o próprio processo de crescimento facial. Embora não 
tenha ocorrido significância estatística, observou-se uma tendência de fechamento dos ângulos FMA e SN.GoGn para os grupos I, III e IV, conforme a Figura 6.1. O comportamento destes ângulos encontra-se dentro do esperado para uma face equilibrada em crescimento, como verificado por HELMANN $^{87}$ e MARTINS et al ${ }^{127}$. BEATRICE;WOODS ${ }^{12}$, CAPELOZZA FILHO et al $^{39}$ e STAGGERS ${ }^{193}$ alcançaram resultados bastante semelhantes.

O Grupo II apresentou um suave aumento dos ângulos FMA e SN.GoGn em relação aos outros grupos, concordando com CUSIMANO et al. $^{53}$, DOUGHERTY ${ }^{62}$, KIM; MUHL ${ }^{109}$ e MCLAUGHLIN; BENNETT ${ }^{132}$. Uma possível explicação para a diferença de comportamento destes ângulos é o fato de se tratar de más oclusões de Classe I cuja abordagem terapêutica foi realizada sem extrações dentárias. Comparando-se as medidas cefalométricas lineares correspondentes ao movimento ântero-posterior dos molares superiores e inferiores, DMS-PTV e DMI-PTV, respectivamente, embora não tenham sido estatisticamente significantes, observou-se que estas duas medidas foram menores para o Grupo II, ou seja, houve uma menor mesialização neste grupo. Isto pode ter ocorrido devido principalmente ao processo de crescimento normal, pois não havia interesse em se alterar a relação ântero-posterior dos molares superiores e inferiores. Isso porque a relação molar já era normal, tornando o tratamento ortodôntico basicamente resumido à correção do suave apinhamento anterior. Simultaneamente a esse fenômeno, o crescimento dos processos dentoalveolares posteriores e a extrusão causada pela mecânica ortodôntica, podem ter contribuído para uma rotação horária da mandíbula, observada pelas alterações nos ângulos FMA e SN.GoGn. CUSIMANO et $\mathrm{al}^{53}$, DOUGHERTY ${ }^{62}$, KLAPPER et al. ${ }^{111} \mathrm{e}$ 


\section{Disaussão}

MCLAUGHLIN; BENNET ${ }^{132}$ também verificaram um pequeno aumento destes ângulos em casos tratados ortodonticamente.

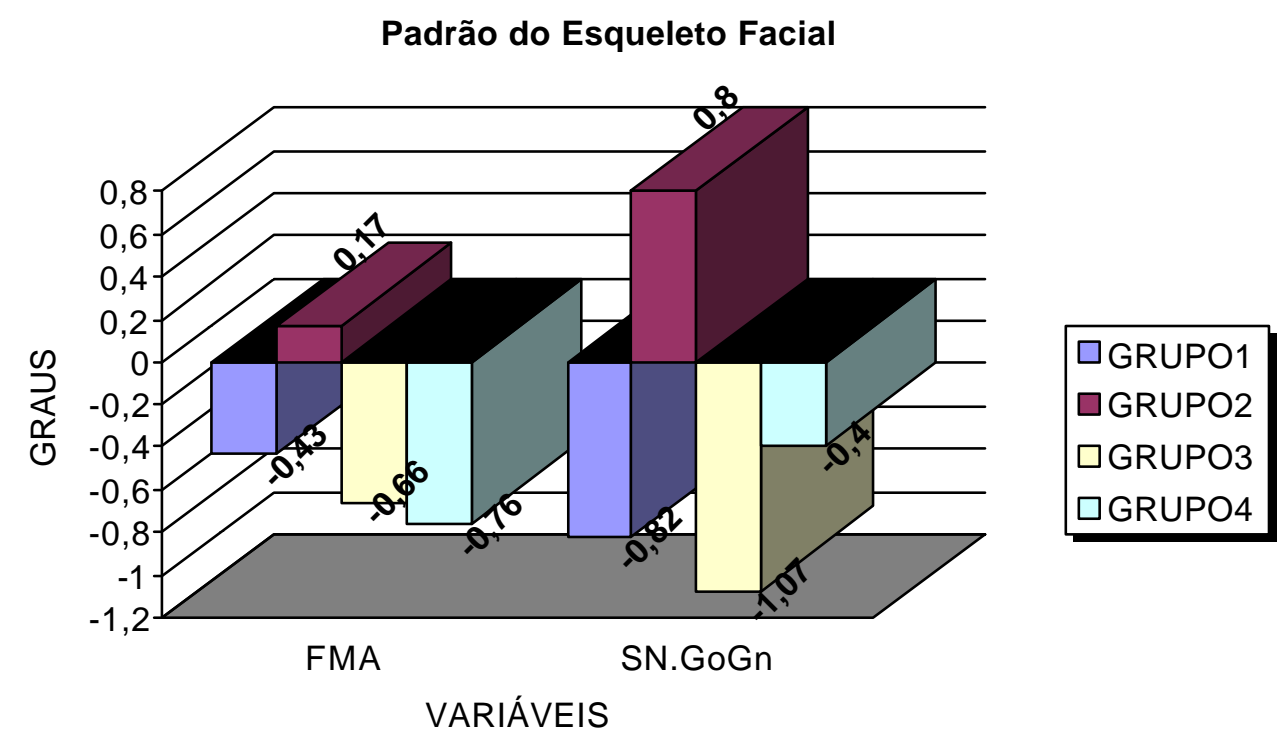

FIGURA 6.1 - Alterações das medidas angulares esqueléticas.

\subsubsection{PFH, AFH e HORN}

O Índice de Horn, proposto por André $\mathrm{HORN}^{91}$, em 1992, pode ser definido como sendo a proporção entre a medida PFH (distância em milímetros do ponto articular ao plano mandibular, medido ao longo da borda posterior do ramo ascendente da mandíbula) e AFH (distância em milímetros do ponto mentoniano ao plano palatino).

$$
\mathrm{HORN}=\frac{\mathrm{PFH}}{\mathrm{AFH}} \times 100
$$


Este índice indica o sentido da rotação mandibular durante o tratamento ortodôntico. Segundo o autor, é particularmente útil no tratamento da Classe II, $1^{\text {a }}$ divisão, pois se a altura facial posterior aumentar mais rapidamente que a altura facial anterior, o índice irá aumentar, colaborando para a obtenção de um perfil facial mais harmonioso, além de auxiliar na correção ânteroposterior da má oclusão, uma vez que a mandíbula sofre rotação no sentido anti-horário como nos casos de oclusão normal.

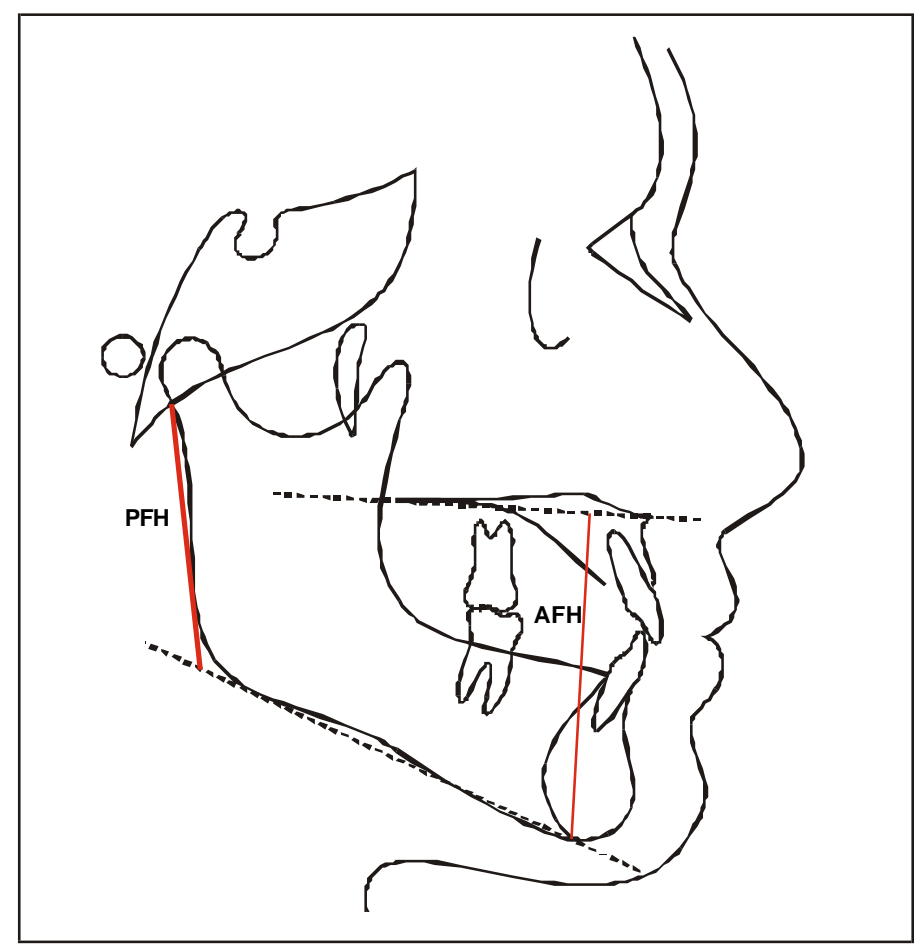

FIGURA 6.2 - Medidas utilizadas no Índice de HORN ${ }^{91}$

De acordo com as alterações verificadas na Figura 6.3, observou-se que nos Grupos I e III o Índice de Horn aumentou de maneira significante, ou seja, a altura facial posterior aumentou mais que a altura facial anterior. $\mathrm{O}$ incremento na $\mathrm{AFH}$ foi menor que na PFH devido a dois possíveis fatores: a influência da extração dos quatro primeiros pré-molares e o processo normal de crescimento. As extrações dos primeiros pré-molares permitiram uma 
maior mesialização dos molares superiores e inferiores, compensando a extrusão dos mesmos, corroborando com YAMAGUCHI; NANDA ${ }^{217}$, CAPELOZZA FILHO et $\mathrm{al}^{39}$. Com o controle da AFH e o aumento da PFH, o Índice de HORN aumentou. Como o aparelho ortodôntico tem pequena influência direta na $\mathrm{PFH}$, seu aumento se deve primariamente ao crescimento, concordando com BISHARA et al. ${ }^{17}$, CAPELOZZA FILHO et al. ${ }^{39}$, HELLMAN $^{83}$, KROGMAN ${ }^{113}$ e VADEN; HARRIS; SINCLAIR ${ }^{206}$.

O grupo II, por sua vez, demonstrou aumento significante para PFH e $\mathrm{AFH}$, mas o Índice de Horn não demonstrou alteração estatisticamente significante. Apesar disto, houve uma suave diminuição nessa proporção. Esse resultado pode ser explicado pelo fato da altura facial anterior ter aumentado suavemente mais neste grupo do que nos grupos I e III. Os suaves aumentos nos ângulos FMA e SN.GoGn reforçam essa idéia.

Já no grupo IV, houve aumento dos valores de $\mathrm{PFH}$ e AFH, mas o Índice de Horn não demonstrou significância. Apesar disso, o mesmo apresentou um suave aumento, como seria de se esperar, uma vez que PFH foi suavemente maior que $\mathrm{AFH}$. 


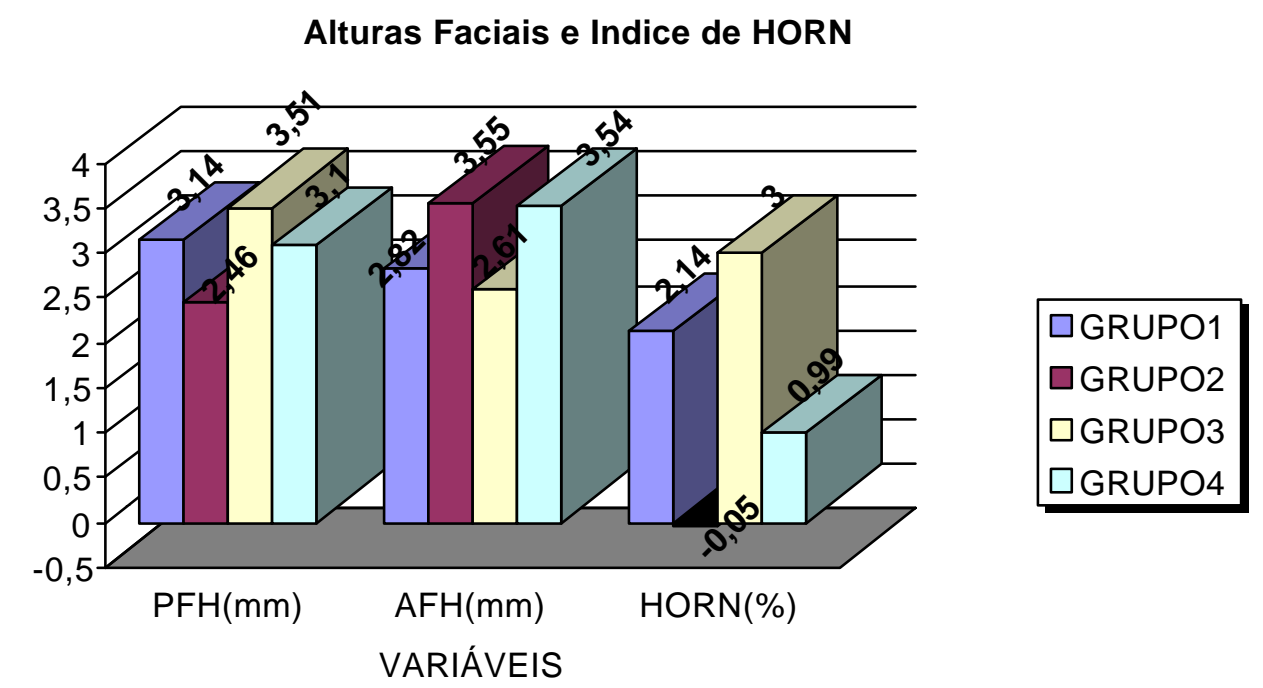

FIGURA 6.3 - Alterações das alturas faciais póstero-inferior e ântero-inferior e do Índice de HORN $^{91}$

\subsubsection{AFP, AFA e AFP/AFA}

A proporção AFP/AFA corresponde ao quociente de Jarabak, definido por SIRIWAT \& JARABAK ${ }^{186}$, em que a AFP corresponde à medida linear entre os pontos $\mathrm{S}$ e Go e a AFA, entre os pontos $\mathrm{N}$ e $\mathrm{Me}$.

De acordo com os resultados mostrados nas Tabelas 5.3 e 5.5, os Grupos I e III apresentaram aumentos estatisticamente significantes para as três mensurações. Este comportamento das medidas citadas possivelmente refletiu mais uma vez que a mecânica ortodôntica com e sem extrações controlou a altura facial anterior, permitindo que a altura facial posterior aumentasse de acordo com o potencial de crescimento para uma face equilibrada, estando de acordo com GEBECK ${ }^{77}, \mathrm{SCHUDY}^{184}$, AIDAR \& 
SCANAVINI $^{2}$, SIRIWAT \& JARABAK ${ }^{186}$ e KOCADERELLI ${ }^{112}$, VADEN; HARRIS; SINCLAIR ${ }^{206}$.

Os grupos II e IV demonstraram aumentos significantes para as medidas AFP e AFA, porém, o quociente de Jarabak não demonstrou significância estatística, apesar de apresentar um pequeno aumento, talvez pelo fato do aumento de AFP ser suavemente maior que o aumento de AFA.

Alturas faciais e Quociente de SIRIWAT \& JARABAK

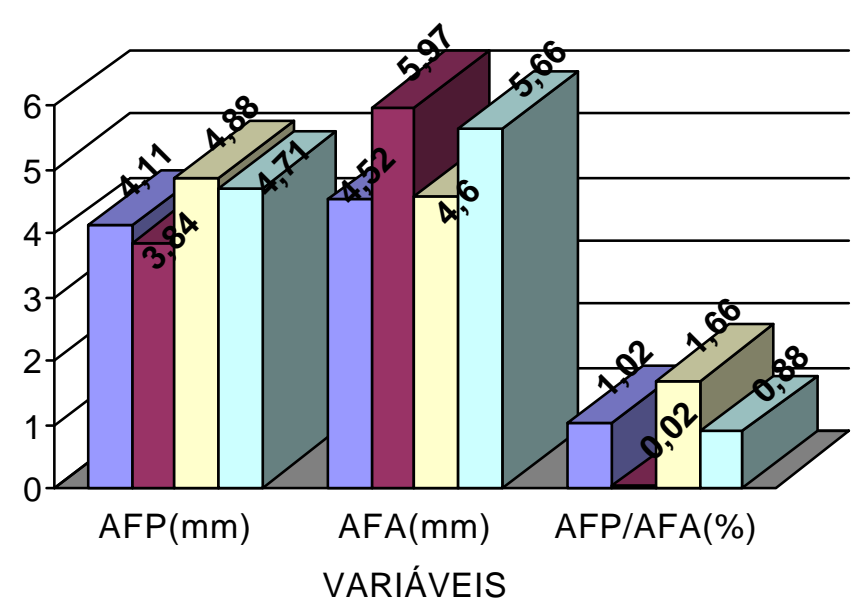

FIGURA 6.4 - Alterações das alturas faciais posterior e anterior e do Quociente de Siriwat $\& \operatorname{Jarabak}^{186}$.

\subsubsection{AFA, AFAS, AFAI, AFAI/AFA, AFAI/AFAS e AFAS/AFA}

Os resultados das Tabelas 5.3 a 5.6 revelaram um aumento significante para as medidas AFA, AFAI e AFAS para todos os grupos estudados, estando de acordo com STAGGERS ${ }^{193}$. CHUA; LIM; LUBIT $^{45}$ observaram aumento das alturas faciais anteriores em casos de Classe I e II sem extração. Nos casos com extrações, porém, o aumento não foi estatisticamente significante. 
Entretanto, esse pequeno aumento pode ser atribuído ao fato do autor não ter utilizado ancoragem extrabucal em seus pacientes, concordando com NANDA. ${ }^{149}$ Como no presente trabalho os pacientes utilizaram ancoragem extrabucal cervical, deve-se levar em consideração também o componente vertical deste sistema de forças, além da influência da placa lábio-ativa sobre a verticalização dos molares inferiores.

Ao se verificar as proporções AFAI/AFA, AFAI/AFAS e AFAS/AFA, não se observaram diferenças estatisticamente significantes em nenhum dos quatro grupos. Estes resultados demonstraram que não houve alterações nas proporções faciais anteriores durante o período de tratamento ativo, cuja média foi de 2,49 anos. KIM; MUHL ${ }^{109}$, estudando pacientes com Classe II, $1^{\text {a }}$ divisão tratados com AEB cervical e sem extrações, verificaram que a proporção AFAI/AFA diminuiu $0,1 \%$, porém esta alteração não foi estatisticamente significante. Essa diminuição pode ter ocorrido devido ao tempo de tratamento bastante extenso, 4 anos, em média. Apesar de alguns autores ${ }^{18,137,150,179,207}$ relatarem que estas proporções se modificam com a idade, possivelmente isso não ocorreu neste estudo pelo fato do intervalo de tempo estudado ter sido muito pequeno em relação ao que se verificou nos estudos sobre as alterações das proporções faciais no crescimento. Outra possível explicação é a influência da força muscular, que atua no intuito de manter o comprimento de repouso muscular, fazendo com que as alterações dentoalveolares ocorram de modo a compensar o padrão de crescimento equilibrado da amostra. 


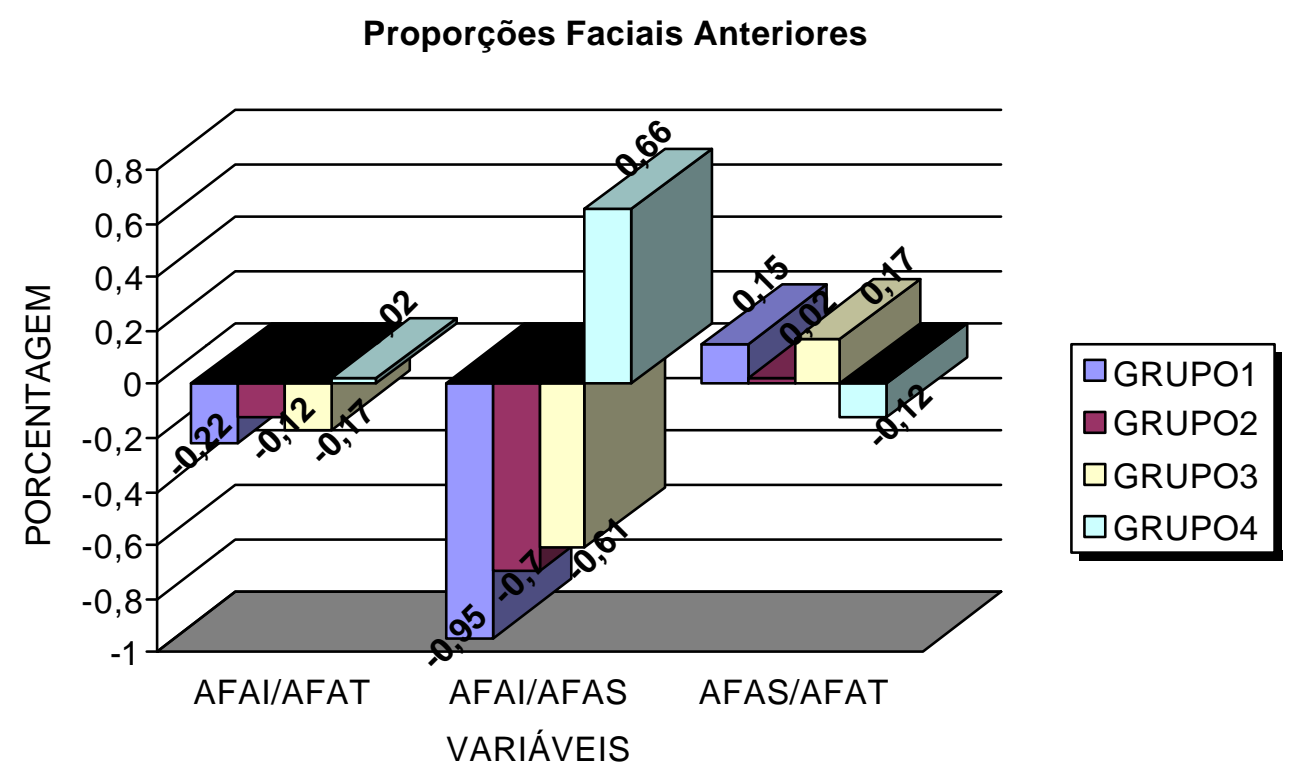

FIGURA 6.5 - Alterações das proporções faciais anteriores.

\subsection{Medidas dentoalveolares}

\subsubsection{CMS-Franc e CMS-PP}

As medidas dentoalveolares CMS-Franc e CMS-PP correspondem à quantidade de movimento no sentido vertical que os molares superiores apresentaram em relação ao plano de Francfort e ao plano palatino, respectivamente.

Como ilustrado nas Tabelas 5.3 a 5.6, houve diferenças estatisticamente significantes entre as medidas inicial e final para os quatro grupos, quando estudados individualmente. CAPELOZZA FILHO et al. ${ }^{39}$ também encontraram aumento significante nestas medidas em casos de Classe II, $1^{\text {a }}$ divisão tratados com extração dos quatro primeiros pré-molares. Por outro lado, na comparação entre os grupos, realizada por meio da ANOVA, não se 


\section{Disaussão}

verificaram diferenças estatisticamente significantes (Tabela 5.11). Ao se analisar os grupos com extração, I e III, observa-se que apesar da extrusão dos molares superiores ter apresentado valores maiores que os grupos sem extração, houve também uma maior mesialização dos mesmos, verificada pela medida DMS-PTV. Isso sugere que, embora o tratamento ortodôntico com extração dos quatro primeiros pré-molares apresente maior extrusão dos molares superiores, a mesialização dos mesmos compensa o desenvolvimento vertical.

O desenvolvimento vertical dos molares superiores provavelmente recebeu duas influências: a extrusão pela mecânica ortodôntica, de acordo com STAGGERS ${ }^{193}$, e o processo de crescimento normal, como demonstrado por MARTINS et al. ${ }^{127}$

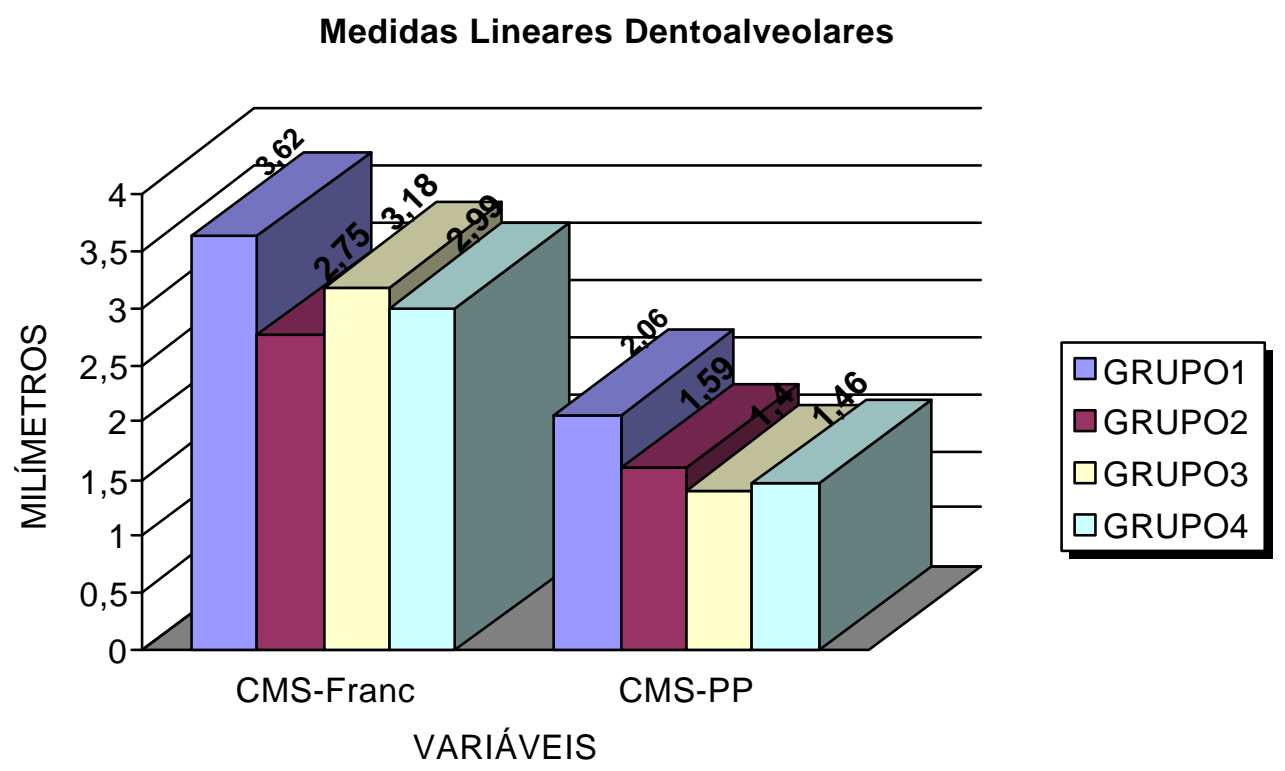

FIGURA 6.6 - Alterações das distâncias entre a ponta de cúspide mesial do primeiro molar superior permanente e o plano de Francfort (CMS-Franc) e o plano palatino (CMS-PP). 


\subsubsection{CMI-PM}

A medida linear CMI-PM representa o desenvolvimento vertical dos molares inferiores em relação ao plano mandibular.

Observando-se a Figura 6.7 e as Tabelas 5.3 a 5.6, verifica-se que os molares inferiores apresentaram uma extrusão estatisticamente significante para os quatro grupos, estando em concordância com CAPELOZZA FILHO et al. $^{39}$, CLEALL; BEGOLE; CHEBIB ${ }^{46}$, CREEKMORE $^{51}$, DOUGHERTY ${ }^{62}$, RICKETTS $^{171}$ e SCHUDY ${ }^{182}$. Semelhantemente ao ocorrido com os molares superiores, embora o tratamento ortodôntico com extração dos quatro primeiros pré-molares tenha apresentado uma extrusão suavemente maior dos molares inferiores, a mesialização dos mesmos compensou o desenvolvimento vertical.

A extrusão dos molares inferiores pode ser atribuída ao efeito extrusivo da mecânica ortodôntica, como por exemplo, o nivelamento da Curva de Spee e o uso de elásticos de Classe II, estando de acordo com STAGGERS ${ }^{192,193}$ e CUSIMANO et $\mathrm{al}^{53}$. O crescimento também pode ser um importante fator, confirmando os relatos de STAGGERS ${ }^{193}$. VILLALOBOS; SINHA; NANDA $^{208}$ verificaram maior extrusão nos molares inferiores em relação aos superiores e indicaram para pacientes dolicofaciais, o tratamento precoce com um arco lingual fixo a partir dos 7 anos de idade para controlá-los. RICKETTS $^{171}$ observou que os molares inferiores se desenvolveram no sentido vertical aproximadamente 3,3 milímetros durante 30 meses de tratamento, sendo que o grupo controle, composto por Classe I e Classe II, apresentou um aumento de 1,5 milímetros durante o mesmo intervalo de 
tempo. CREEKMORE ${ }^{51}$ encontrou um aumento de 1,59 milímetros em jovens não tratados. Para os casos com extração, DOUGHERTY ${ }^{62}$ notou um aumento de 3,4 milímetros e para os casos sem extração e com preparo de ancoragem, 2,6 milímetros.

O desenvolvimento vertical dos molares inferiores pode sugerir que tais dentes sejam um dos principais responsáveis pela correção da sobremordida e pelo nivelamento da Curva de Spee quando a mecânica de fio contínuo é utilizada, como afirmam CAPELOZZA FILHO et al. ${ }^{39}$ e SCHUDY ${ }^{182,183}$.

\section{Medida Linear Dentoalveolar}

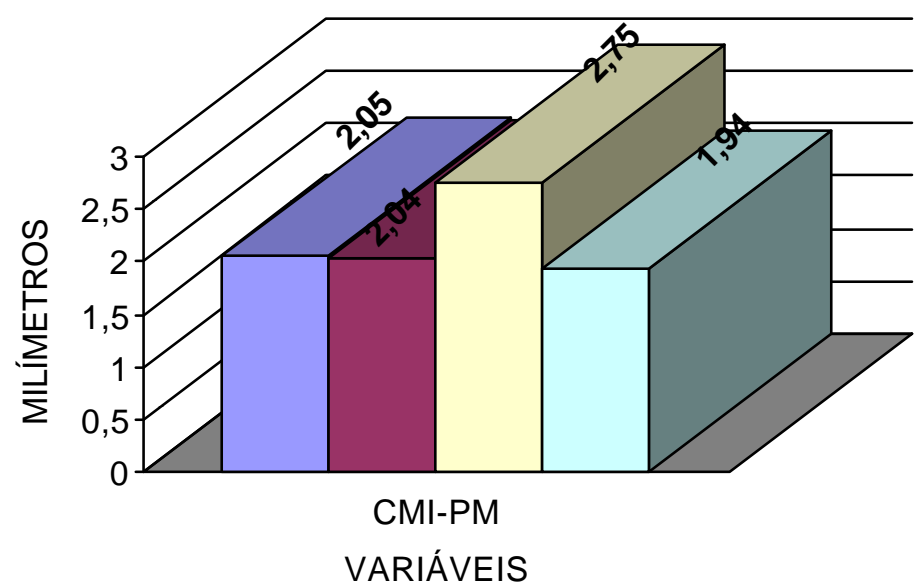

FIGURA 6.7- Alterações da distância entre a ponta de cúspide mesial do primeiro molar inferior permanente e o plano mandibular. 


\section{Disaussão}

\subsubsection{DMS-PTV, DMI-PTV}

As medidas lineares horizontais DMS-PTV e DMI-PTV representam, respectivamente, a mesialização dos molares superiores e inferiores em relação à linha PTV.

Os resultados angariados mostraram que houve uma mesialização dos molares inferiores estatisticamente significante para os quatro grupos estudados. Quanto aos molares superiores, verificou-se que sua mesialização em relação à linha PTV foi estatisticamente significante somente para os grupos tratados com extração (Grupos I e III), o que era o esperado. KOCADERELLI $^{112}$ também observou uma diferença estatisticamente significante apenas na medida DMS-PTV, em que os casos de Classe I tratados com extração de primeiros pré-molares apresentaram uma mesialização quase três vezes maior que nos casos tratados sem extração. $\mathrm{O}$ autor, entretanto, não utilizou nenhuma ancoragem extrabucal, sendo este um dos possíveis motivos que levaram a uma mesialização significante dos molares superiores. No presente estudo, verficou-se uma mesialização dos molares superiores nos casos tratados com extração, porém este movimento dentário não foi tão acentuado uma vez que todos os pacientes da amostra utilizaram ancoragem extrabucal.

Geralmente, os casos de más oclusões de Classe I tratados com extração dos quatro primeiros pré-molares, necessitam destes espaços para solucionarem as discrepâncias de modelo e cefalométrica mais acentuadas, ou seja, maiores que quatro milímetros. Assim sendo, grande parte dos espaços das extrações é utilizada pelos dentes anteriores e a ancoragem extrabucal, 
nesses casos, tem o objetivo de manter a relação molar normal, principalmente durante a fase de retração anterior.

Em relação à correção da Classe II, deve-se considerar que, em pacientes na fase de crescimento, a relação molar é corrigida por meio de uma restrição da mesialização dos molares superiores promovida pela ancoragem extrabucal e de uma mesialização dos molares inferiores em relação aos superiores, pelo próprio processo de crescimento, tanto nos casos com como nos sem extração. Os molares superiores não demonstraram distalização em relação à linha PTV, mas sim mesialização. A ancoragem extrabucal permitiu que os molares superiores mesializassem menos que os inferiores, auxiliando na correção da Classe II. Provavelmente, se a ancoragem extrabucal não tivesse sido utilizada nestes casos, a mesialização dos molares superiores seria muito mais acentuada, o que dificultaria a correção da relação molar. Estes resultados encontram-se em concordância com os de CARVALHO ${ }^{41}$ Apesar da mesialização "controlada" dos molares superiores no Grupo III, com a retração anterior, os molares também sofreram mesialização, mesmo que de pequena magnitude, fazendo com que apresentasse diferença estatisticamente significante na medida dentoalveolar DMS-PTV. Já o Grupo IV, tratado sem extrações, apresentou menor mesialização dos molares superiores em relação ao Grupo III. 


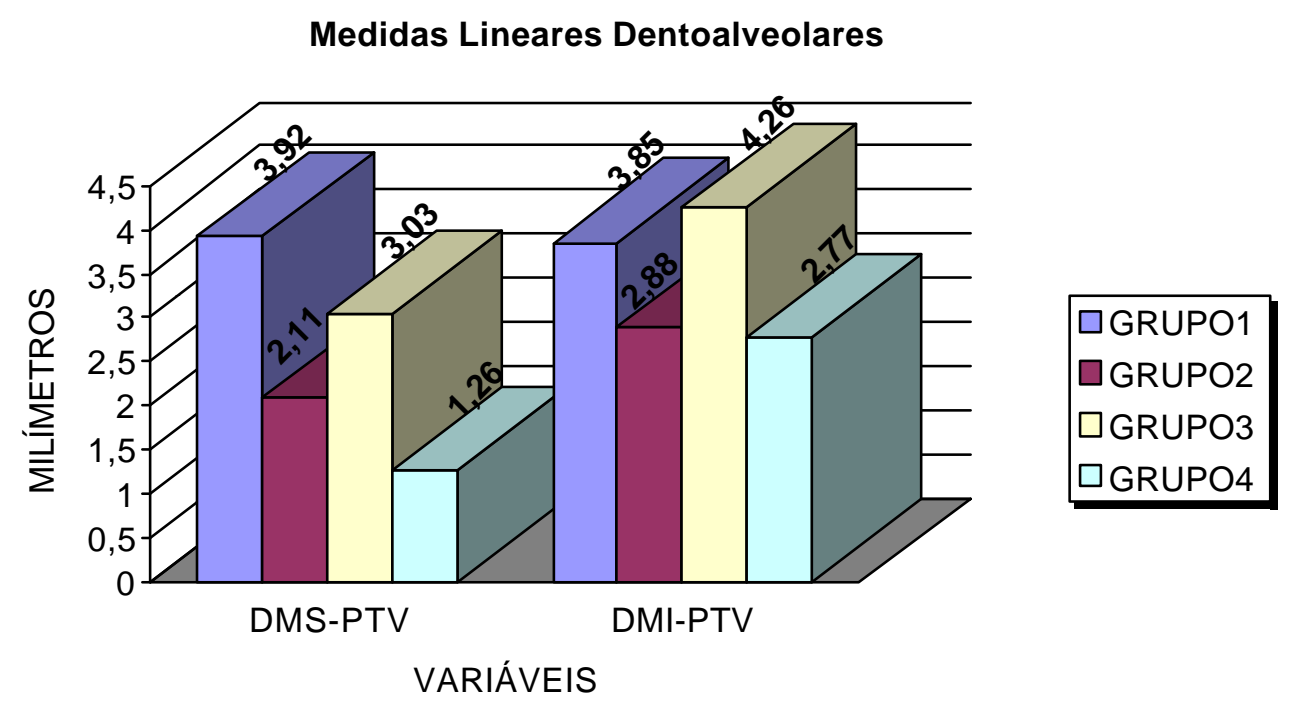

FIGURA 6.8 - Alterações das distâncias horizontais entre a face distal dos primeiros molares superior e inferior permanentes e a linha PTV.

\subsection{Dimorfismo entre os gêneros}

Por meio do teste " $\mathrm{t}$ " não pareado, verificou-se que nos grupos tratados sem extração, grupos II e IV, não houve dimorfismo entre os gêneros. No grupo I, houve dimorfismo apenas nas medidas dentoalveolares DMS-PTV e DMI-PTV, em que o gênero masculino apresentou valores maiores que o feminino, ou seja, o movimento de mesialização foi mais acentuado no masculino. A explicação mais plausível é o fato dos meninos, cuja idade média ao início do tratamento foi de 12,15 anos, poderem estar atingindo o pico de crescimento máximo na fase de tratamento, ao passo que as meninas, cuja idade média foi de 12,20 anos, já estariam na fase descendente de crescimento, fazendo com que a mecânica, neste caso, imperasse mais. MCNAIR $^{133}$, estudando o crescimento vertical, observou também que o maior 


\section{Disaussão}

aumento ocorre entre as idades de 12 e 13 anos no gênero masculino e entre os 11 e 12 anos no gênero feminino, ou seja, durante o pico de crescimento. Assim, sugere-se que, em casos com idade média semelhante ao do presente estudo, e cujo objetivo do tratamento é a ancoragem dos molares, a ancoragem máxima (ancoragem extrabucal, placa lábio-ativa e elásticos de Classe III) se faz mais necessária nos meninos do que nas meninas.

No grupo III, o gênero masculino apresentou maiores alterações nas medidas CMI-PM, PFH e AFP em relação ao gênero feminino, talvez por estar atingindo o pico máximo de crescimento. Isso significa que, embora o desenvolvimento vertical dos molares inferiores tenha sido maior nos meninos, a dimensão vertical foi mantida pelo maior aumento compensatório da altura facial posterior. Daí a explicação também de não haver diferença estatisticamente significante entre os gêneros nas proporções entre as alturas faciais posterior e anterior.

\subsection{Correlações estudadas}

\subsubsection{Correlação entre as alterações das medidas FMA, SN.GoGn e PFH, AFH, PFH/AFH, AFP, AFA, AFP/AFA, CMS-Franc, CMS-PP, CMI-PM}

Nesta parte do estudo, analisaram-se as possíveis correlações entre as medidas angulares FMA e SN.GoGn e as alturas faciais anterior, posterior, as proporções entre elas e as medidas dentoalveolares CMS-Franc, CMS-PP e CMI-PM nos quatro grupos (Tabelas 5.12 a 5.15). 
Em toda a amostra, observou-se uma correlação negativa entre FMA e SN.GoGn e PFH/AFH e AFP/AFA, ou seja, a diminuição dos ângulos FMA e SN.GoGn relacionou-se com o aumento das proporções PFH/AFH e AFP/AFA. Estas correlações poderiam sugerir que a mecânica de "edgewise" simplificada, realizada com ou sem extrações dentárias, em pacientes com padrão facial equilibrado, é eficiente no controle da AFA, permitindo que a AFP se desenvolva normalmente, uma vez que, se os ângulos do padrão de crescimento não se alteraram significantemente é porque a AFA foi convenientemente controlada.

Principalmente para os casos de Classe II, essa correlação é muito importante, pois indica uma resposta favorável da mandíbula ao sistema de forças utilizado, o que favorece a obtenção da melhora do perfil facial, contribuindo também para a estabilidade a longo prazo.

No grupo III, verificou-se a existência de uma correlação entre as medidas dentoalveolares CMS-Franc e CMS-PP e as esqueléticas FMA e SN.GoGn. Entretanto, embora os ângulos SN.GoGn e FMA possam ter recebido influência do componente extrusivo dos molares superiores, não demonstraram aumento, provavelmente pela compensação do crescimento da AFP e pela mesialização dos molares, o que corrobora com os relatos de CUSIMANO $^{53}$. 


\subsubsection{Correlação entre as alterações da altura facial anterior e as medidas lineares dentoalveolares CMS-Franc, CMS-PP, CMI-PM, DMS-PTV e DMI-PTV}

Testaram-se as correlações entre as alterações da altura facial anterior e as medidas dentoalveolares CMS-Franc, CMS-PP, CMI-PM, DMS-PTV, DMI-PTV (Tabelas 5.16 a 5.19). Verificou-se uma correlação positiva entre a AFA e CMI-PM nos quatro grupos estudados, ou seja, o aumento estatisticamente significante da AFA encontrou-se diretamente relacionado ao aumento da medida CMI-PM. Para se localizar o componente da altura facial anterior mais envolvido com este aumento, verificou-se a medida AFAI. Uma vez que houve correlação positiva entre a AFAI e CMI-PM, denota-se que o aumento estatisticamente significante na AFAI recebeu bastante influência do componente dentoalveolar CMI-PM. Nos grupos I, III e IV, verificou-se também uma correlação positiva entre AFA e AFAI e as medidas CMS-Franc e CMS-PP. Todos estas correlações corroboram com os resultados de RICKETTS $^{171}$. Em seu estudo, afirmou que aproximadamente $60 \%$ do aumento da altura facial anterior total se deve às estruturas dentoalveolares.

As correlações positivas entre as medidas DMS-PTV e AFAI e entre DMI-PTV e AFAI foram observadas no grupo II. Isto provavelmente ocorreu sob influência do crescimento e não da mecânica ortodôntica. 


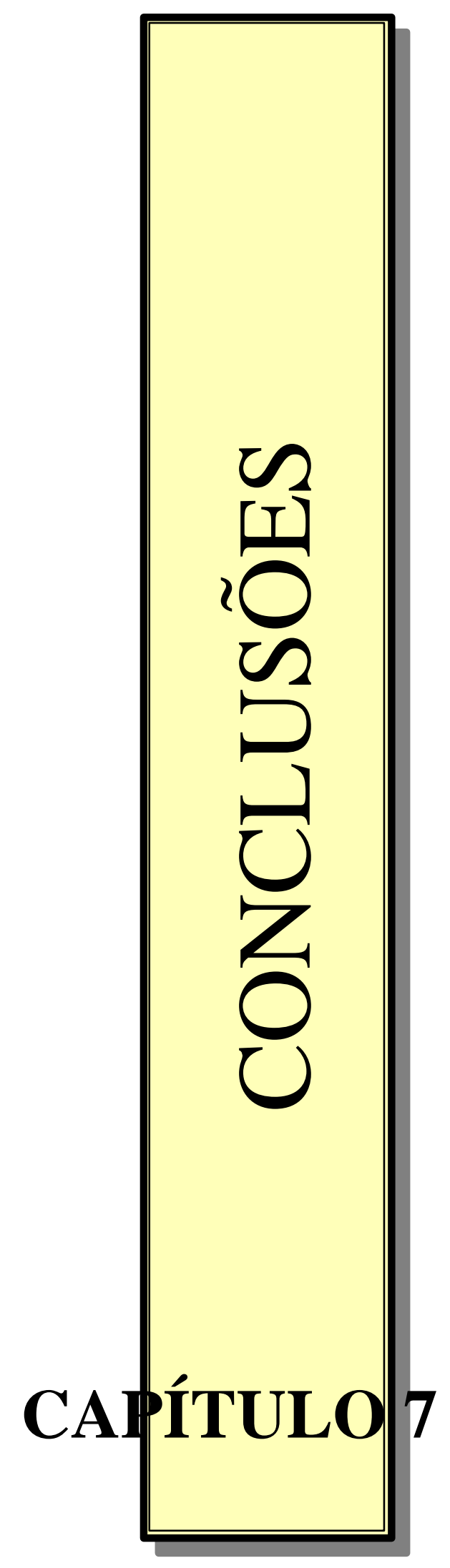




\section{Condusões}

\section{CONCLUSÕES}

Baseando-se nos resultados obtidos e na metodologia utilizada, julga-se lícito concluir que:

7.1 - As alterações nas alturas faciais anterior e posterior foram similares nos quatro grupos estudados, apresentando aumento de ambas ao final do tratamento ortodôntico.

7.2 - As alterações dos ângulos FMA e SN.GoGn não foram estatisticamente significantes.

7.3 - Quanto ao Índice de Horn, verificou-se que:

7.3.1- Houve aumento nos Grupos I e III, ou seja, a altura facial posterior ( $\mathrm{PFH})$ aumentou mais que a anterior (AFH).

7.3.2- O Grupo II demonstrou aumento significante para PFH e AFH, porém o Índice de Horn não demonstrou alteração estatisticamente significante.

7.3.3- O Grupo IV, por sua vez, apresentou aumentos significantes na PFH e na AFH e, embora o Índice de Horn não tenha demonstrado alteração significante, apresentou um discreto aumento, pois PFH aumentou suavemente mais que a AFH. 


\section{Condusões}

7.4- Os grupos I e III apresentaram aumentos estatisticamente significantes para AFP, AFA e para a proporção AFP/AFA. Os grupos II e IV demonstraram aumentos estatisticamente significantes para AFP e AFA, porém, o aumento da proporção AFP/AFA não demonstrou significância estatística, pelo fato do aumento de AFP ser suavemente maior que o aumento de AFA.

7.5- Apesar das medidas lineares AFA, AFAI e AFAS revelarem aumento estatisticamente significante para os quatro grupos, as proporções AFAI/AFA, AFAI/AFAS e AFAS/AFA não se alteraram no período de tratamento ativo.

7.6 - Não houve dimorfismo entre os gêneros quanto às alterações nas alturas faciais anterior e posterior. Observou-se dimorfismo apenas nas medidas dentoalveolares DMS-PTV e DMI-PTV, no Grupo I, em que o gênero masculino apresentou valores maiores que o feminino. No Grupo III, o gênero masculino apresentou alterações maiores nas medidas CMI-PM, PFH e AFP em relação ao feminino. 


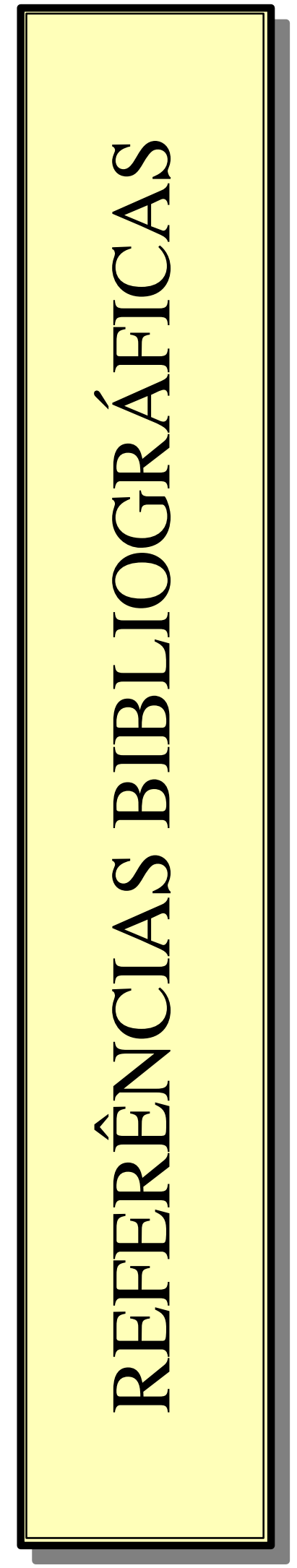




\section{REFERÊNCIAS BIBLIOGRÁFICAS}

1. AHN, J.G.; SCHNEIDER, B.J. Cephalometric appraisal of posttreatment vertical changes in adult orthodontic patients. Amer. J. Orthodont. Orthop. Dentofac., v.118, n.4, p.378-84, Oct. 2000.

2. AIDAR, L.A.A.; SCANAVINI, M.A. Estudo comparativo cefalométrico radiográfico dos padrões de crescimento facial em pacientes portadores de oclusão normal e maloclusões de Classe I, Classe II, divisão 1, Classe II, divisão 2, e de Classe III, de Angle, de acordo com SIRIWAT \& JARABAK. Ortodontia, v.22, n.2, p.31-52, Mai/Ago. 1989.

3. ALMEIDA, P.D. Estudo comparativo entre os padrões cefalométricosradiográficos da análise de Steiner e os encontrados em brasileiros, leucodermas, portadores de oclusão normal. São Bernardo do Campo, 1986. 91p. Dissertação (Mestrado) - Instituto Metodista de Ensino Superior.

4. ALTEMUS, L.A. A comparison of cephalofacial relatioships. Angle Orthodont., v.30, n.4, p.233-40, Oct. 1960

5. ANGLE, E.H. Classification of malocclusion. Dent. Cosmos, v.41, p.246-64, 1899.

6. ANGLE, E.H. Malocclusions of the teeth. 7.ed. Philadelphia, S.S. White, 1907.

Normas recomendadas para uso no âmbito da Universidade de São Paulo, com base no documento "Referências Bibliográficas: exemplos", emanado do Conselho Superior do Sistema Integrado de Bibliotecas da USP, em reunião de 20 de setembro de 1990. 


\section{Referênaias Bibliográficas}

7. ARIZA DIAZ, M.C.; PINZAN, A.; HENRIQUES, J.F.C. Avaliação comparativa do crescimento maxilomandibular em crianças leucodermas brasileiras, com oclusão normal, utilizando as medidas Co-A, Co-Gn, AFAI e Dif. Mand./Max. da análise cefalométrica proposta por McNamara Jr. Estudo longitudinal. Ortodontia, v.26, n.1, p.14-37, Jan./Abr. 1993.

8. ARNETT, G.W.; BERGMAN, R.T. Facial keys to orthodontic diagnosis and treatment planning- Part II. Amer. J. Orthodont. Dentofac. Orthop., v.103, n.5, p.395-411, May 1993.

9. BAIRD, F.P. Cephalometric evaluation of the skeletal and dental pattern of seven to nine-year-old children with excellent occlusions. Washington, 1952. Thesis University of Washington apud JANSON, G.R.P.; MARTINS, D.R. Estudo longitudinal e comparativo do crescimento facial dos 13 aos 18 anos de idade em jovens brasileiros leucodermas, utilizando a análise cefalométrica de McNamara Jr. Bauru, 1990. 138p. Tese (Doutorado)- Faculdade de Odontologia de Bauru, Universidade de São Paulo.

10. BASS, N.M. The aesthetic analysis of the face. Eur. J. Orthodont., v.13, p.34350, 1991.

11. BAUM, A.T. A cephalometric evaluation of the normal skeletal and dental pattern of children with excellent occlusions. Angle Orthodont., v.21, p.96-103, 1951.

12. BEATRICE, M.; WOODS, M. Vertical facial pattern and orthodontic stability. Part II: facial axis changes and stability. Austr. J. Orthodont., v.16, n. 3, p.133-9, Nov. 2000.

13. BELCHIER, J. Communication. Roy. Soc. Phil. Trans., v.39, p.287, 1736 apud BRODIE, A.G. On the growth pattern of human head from the third month to the eight years. Am. J. Anat., v.68, p.209-62, 1941. 


\section{ReferêndiasBibliográficas}

14. BERGENSEN, E.O. The direction of facial growth from infancy to adulthood. Angle Orthodont., v.36, n.1, p.18-43, Jan. 1966.

15. BERTOZ, F.A.; MARTINS, D.R. Determinação da linha "I" em melanodermas brasileiros, masculinos, de 12 a 17 anos, com oclusão normal. Ortodontia, v.14, n.3, p.186-98, set./dez. 1981.

16. BILODEAU, J.E. Vertical considerations in diagnosis and treatment. A surgical orthodontic case report. Amer. J. Orthodont. Dentofac. Orthop., v.107, n.1, p.91-100, Jan. 1995.

17. BISHARA, S.E. Facial and Dental changes in adolescents and their clinical implications. Angle Orthodont., v.70, n.6, p.471-83, Dec. 2000.

18. BISHARA, S.E. Longitudinal cephalometric standards from 5 years of age to adulthood. Amer. J. Orthodont., v.79, n.1, p.35-44, Jan. 1981.

19. BISHARA, S.E.; BAYATI, P.; JAKOBSEN, J.R. Longitudinal comparisons of dental arch changes in normal and untreated Class II, Division 1 subjects and their clinical implications. Amer. J. Orthodont. Orthop. Dentofac., v.110, n.5, p.483-9, Nov. 1996.

20. BISHARA, S.E.; CUMMINS, D.M.; ZAHER, A.R. Treatment and posttreatment changes in patients with Class II, Division 1 malocclusion after extraction and nonextraction treatment. Amer. J. Orthodont. Orthop. Dentofac., v.111, n.1, p.18-27, Jan. 1997.

21. BISHARA, S.E.; JAKOBSEN, J.R. Longitudinal changes in three normal facial types. Amer. J. Orthodont., v.88, n.6, p.466-502, Dec. 1985. 


\section{ReferêndiasBibliográficas}

22. BISHARA, S.E.; PETERSON, L.C.; BISHARA, E.C. Changes in facial dimensions and relationships between the ages of 5 and 25 years. Amer. J. Orthodont., v.85, n.3, p.238-52, Mar. 1984.

23. BISHARA, S.E. et al. Dentofacial and soft tissue changes in Class II, división 1 cases treated with and without extractions. Amer. J. Orthodont. Orthop. Dentofac., v.107, n.1, p.28-37, Jan. 1995.

24. BISHARA, S.E.; JAKOBSEN, J.R. Changes in overbite and face height from 5 to 45 years of age in normal subjects. Angle Orthodont., v.68, n.3, p.207-16, Jun. 1998.

25. BJÖRK, A. The face in profile. Sweed. Dent. J., v.40, p.180, 1947 apud JANSON, G.R.P.; MARTINS, D.R. Estudo longitudinal e comparativo do crescimento facial dos 13 aos 18 anos de idade em jovens brasileiros leucodermas, utilizando a análise cefalométrica de McNamara Jr. Bauru, 1990. 138p. Tese (Doutorado)- Faculdade de Odontologia de Bauru, Universidade de São Paulo.

26. BJÖRK, A. The nature of facial prognathism and its relation to normal occlusion of the teeth. Amer. J. Orthodont., v.37, p.106-24, 1951.

27. BJÖRK, A. Prediction of mandibular growth rotation. Amer. J. Orthodont., v.55, n.6, p.585-99, Jun. 1969.

28. BOWBEER, G.R. The sixth keys to facial beauty and TMJ health. Func. Orthodont., v.14, p.4-22, 1987.

29. BRASH, J.C. Growth of the jaws and palate, dental board of the United Kingdom, 1924 apud WYLIE, W.L. The relationship between ramus height, dental height, and overbite. Amer. J. Orthodont. Oral Surg., v.32, n.2, p.5767, Feb. 1946. 
30. BROADBENT, B. H. A new x-ray technique and its application to orthodontia. Angle Orthodont., v.1, p.45-66, 1931.

31. BROADBENT, B. H. The face of the normal child. Angle Orthodont., v.7, p.183208, 1937.

32. BRODIE, A.G. On the growth of the jaws and the eruption of the teeth. J. Dept. Orthodont., v.12, p.109-23, 1942.

33. BRODIE, A.G. On the growth pattern of human head from the third month to the eight years. Am. J. Anat., v.68, p.209-62, 1941.

34. BRODIE, A.G. Facial patterns: a theme on variation. Angle Orthodont., v.16, p.75-87, 1946.

35. BRODIE, A.G. Appraisal of present concepts in orthodontia. Angle Orthodont., v.20, p.24-38, 1950.

36. BURKE, M.; JACOBSON, A. Vertical changes in high-angle Class II, Division 1 patients treated with cervical or occipital pull headgear. Amer. J. Orthodont. Orthop. Dentofac., v.102, n.6, p.501-8, Dec. 1992.

37. BURNS, M.H. Psychological aspects of orthodontics. In: CINOTTI, W.R.; GRIEDER, A.; SPRINGOB, H.K. Applied psychology in dentistry. 2 ed., St. Louis, Mosby, 1972, p.200-8.

38. CANNON, J. Craniofacial height and depth increments in normal children. Angle Orthodont., v.40, p.202-18, 1970. 


\section{ReferêndiasBibliográficas}

39. CAPELOZZA FILHO, L. Alterações verticais em casos de Classe II divisão 1 dentária com exodontias dos quatro primeiros pré-molares.Rev. Dental Press Ortod Ortop Facial, v.5, n.5, p.12-9, set./out. 2000.

40. CARDOSO, S.M.O. Estudo da estética facial visando à confecção das próteses faciais. Dissertação (Mestrado), Faculdade de Odontologia, Universidade de São Paulo, 238p., São Paulo, 1990.

41. CARVALHO, P.E.G. A influência do padrão de crescimento facial anterior na correção da má oclusão de Classe II, $1^{\text {a }}$ divisão, realizada com aparelho fixo, extração dos primeiros pré-molares e ancoragem cervical. Bauru, 2000. 181p. Dissertação (Mestrado) - Faculdade de Odontologia de Bauru, Universidade de São Paulo.

42. CERCI, V. Estudo comparativo de leucodermas brasileiros em relação aos padrões das análises de Steiner e Downs. Rio de Janeiro, 1979. 74p. Dissertação (Mestrado) - Faculdade de Odontologia da Universidade Federal do Rio de Janeiro.

43. CHAN, G.K.H. A cephalometric appraisal of the Chinese (Cantonese). Amer. J. Orthodont., v.61, n.3, p.279-85, Mar. 1972.

44. CHRISTIE, T.E. Cephalometric patterns of adults with normal occlusion. Angle Orthodont., v.47, n.2, p.128-35, Apr. 1977.

45. CHUA, A.L.; LIM, J.Y.; LUBIT, E.C. The effects of extraction versus nonextraction orthodontic treatment on the growth of the lower anterior face height. Amer. J. Orthodont. Orthop. Dentofac., v.104, n.4, p.361-8, Oct. 1993.

46. CLEALL, J.F.; BEGOLE, A.; CHEBIB, F.S. Craniofacial morphology: a principal component analysis. Amer. J. Orthodont., v.75, n.6, p.650-66,Jun. 1979. 
47. COBEN, S.E. The integration of facial skeletal variants. Amer. J. Orthodont., v.41, n.6, p.407-34, Jun. 1955.

48. COBEN, S.E. Growth concepts. Angle Orthodont., v.31, p.194-201, 1961.

49. COTTON, W.N.; TAKANO, W.S.; WONG, W.M.W. The Downs analysis applied to three other ethnic groups. Angle Orthodont., v.21, n.4, P.213-20, Oct. 1951.

50. COX, N.H.; VAN DER LINDEN, P.G.M. Facial harmony. Amer. J. Orthodont., v.60, n.2, p.175-83, Aug. 1971.

51. CREEKMORE, T.D. Inhibition or stimulation of the vertical growth of facial complex, its significance to treatment. Angle Orthodont., v.37, n.4, p.285-97, Oct. 1967.

52. CROSS, J.J. Facial growth: before, during, and following orthodontic treatment. Amer. J. Orthodont., v.71, n.1, p.68-78, Jan. 1977.

53. CUSIMANO, C.; MCLAUGHLIN, R.P.; ZERNIK, J.H. Effects of first bicuspid extractions on facial height in high-angle cases. J. Clin. Orthodont., v.27, n.11, p.594-8, Nov. 1993.

54. CZARNECKI, S.T.; NANDA, R.S.; CURRIER, G.F. Perceptions of a balanced facial profile. Amer. J. Orthodont. Dentofac. Orthop., v.104, n.2, p.180-7, Aug. 1993.

55. D'CUNHA, K.M. The quadrilateral cephalometric analysis: standardization of its proportional relationship in adults. Thesis graduate Orthodontic Department. Fairleigh Dickinson University, 1983 apud ESTRIPEAUT-LOPEZ, L.E. Estudo longitudinal do conceito de proporcionalidade da análise quadrangular de Di Paolo e sua aplicação em jovens adolescentes 
brasileiros, leucodermas, de origem mediterrânea e com oclusão normal. Dissertação (Mestrado). Faculdade de Odontologia de Bauru, Universidade de São Paulo. Bauru, 111p.

56. DAHLBERG, G. Statistical methods for medical and biological students. New York, Interscience, 1940.

57. DAINESI, E.A. A influência dos padrões extremos de crescimento da face sobre o perfil tegumentar, analisada cefalometricamente em jovens leucodermas brasileiros. Bauru, 1998. 244p. Tese (Doutorado) - Faculdade de Odontologia de Bauru, Universidade de São Paulo.

58. DARENDELILER, N.; TANER-SARISOY, L. The influence of orthodontic extraction treatment on dental structures: a two-factor evaluation. Eur. J. Orthodont., v.23, n.3, p.295-303, jun.2001.

59. DERMAUT, L.R.; O'REILLY, M.I.T. Changes in anterior facial height in girls during puberty. Angle Orthodont., v.48, p.163-71, 1978.

60. DI PAOLO, R.J. The quadrilateral analysis: cephalometric analysis oh the lower face. J. Clin. Orthodont., v.3, p.523-30, 1969.

61. DIAMOND, M. The ramus as a factor in the development of the dental height. J. Dent. Resear., v.22, p.346, 1943.

62. DOUGHERTY, H.L. The effect of mechanical forces upon the mandibular buccal segments during orthodontic treatment. Amer. J. Orthodont., v.54, n.2, p.83103, Feb. 1968.

63. DOWNS, W.B. Variations in facial relationships: their significance in treatment and prognosis. Amer. J. Orthodont. Oral Surg., v.34, n.10, p.812-40, Oct. 1948. 
64. DOWNS, W.B. Analysis of the dentofacial profile. Angle Orthodont., v.26, n.4, p.191-212, Oct. 1956.

65. DRUMMOND, R.A. A determination of cephalometric norms for the Negro race. Amer. J. Orthodont., v.54, n.9, p.670-82, Sept. 1968.

66. DUHAMEL, H.L. Sur une racine qui teint les os en rouge. Communication to the French Academy of Science. 1739 apud BRODIE, A.G. On the growth pattern of human head from the third month to the eight years. Am. J. Anat., v.68, p.209-62, 1941.

67. ESTRIPEAUT LOPEZ, L.E. Estudo longitudinal do conceito de proporcionalidade da análise quadrangular de Di Paolo e sua aplicação em jovens adolescentes brasileiros, leucodermas, de origem mediterrânea e com oclusão normal. Dissertação (Mestrado). Faculdade de Odontologia de Bauru, Universidade de São Paulo. Bauru, 111p.

68. FISH, L.C.; WOLFORD, L.M.; EPKER, B.N. Surgical-orthodontic correction of vertical maxillary excess. Amer. J. Orthodont., v.73, n.3, p.241-57, Mar. 1978.

69. FORZBERG, C.M. et al. Face height and tooth eruption in adults - a 20 years follow-up investigation. Eur. J. Orthodont., v.13, p.249-54, 1991.

70. FOTIS, V. et al. Vertical control as an important ingredient in the treatment of severe sagittal discrepancies. Amer. J. Orthodont., v.86, n.3, p.224-32, Sept. 1984.

71. FREITAS, P.A. Estudo analítico e comparativo do perfil facial mole, em adolescentes brasileiros, leucodermas, apresentando “oclusão normal”, 
com as diversas linhas estéticas preconizadas. Bauru, 1978. 69p. Tese (Mestrado) - Faculdade de Odontologia de Bauru, Universidade de São Paulo.

72. FREITAS, M.R. de; MARTINS, D.R. Estudo cefalométrico da ancoragem inferior, em pacientes tratados com a técnica da classe II, divisão $1^{\mathrm{a}}$, com aparelho extrabucal de Klohen, e aparelho fixo - alterações esqueléticas (Parte I). Rev. Dental Press de Ortodontia e Ortopedia Maxilar, v.2, n.6, p.75-87, nov./dez. 1997.

73. GARNOT, J.S.F. Egipto. In: CONTENAU, G. et al. Historia general del arte. Barcelona, Montaner y Simon, v.1, p.13-37, 1958 apud CARDOSO, S.M.O. Estudo da estética facial visando à confecção das próteses faciais. Dissertação (Mestrado), Faculdade de Odontologia, Universidade de São Paulo, 238p., São Paulo, 1990.

74. GARLINGTON, M.A Changes in mandibular plane angles after second bicuspid enucleation. Califórnia, 1987. Dissertação (Mestrado)- University of Southern California apud CUSIMANO, C.; MCLAUGHLIN, R.P.; ZERNIK, J.H. Effects of first bicuspid extractions on facial height in high-angle cases. J. Clin. Orthodont., v.27, n.11, p.594-8, Nov. 1993.

75. GEBECK, R.T.; MERRIFIELD, L.L. Analysis - Concept and values. Part I. Journal of the Charles Tweed Foundation, v.17, p.19-48, 1989 apud LOCKS, A. Estudo cefalométrico das alturas faciais anterior e posterior, em crianças brasileiras, portadoras de má oclusão Classe I de Angle, na fase de dentadura mista. Araraquara, 1996. 128p. Tese (Doutorado)Faculdade de Odontologia de Araraquara- UNESP.

76. GEBECK, R.T.; MERRIFIELD, L.L. Analysis - Concept and values. Part II. Journal of the Charles Tweed Foundation, v.17, p.63-92, 1989 apud LOCKS, A. Estudo cefalométrico das alturas faciais anterior e posterior, em crianças brasileiras, portadoras de má oclusão Classe I de Angle, na 


\section{ReferênaiasBibliográficas}

fase de dentadura mista. Araraquara, 1996. 128p. Tese (Doutorado)Faculdade de Odontologia de Araraquara- UNESP.

77. GEBECK, T.R. Analysis - concepts and values. Part I. J. Charles H. Tweed Found., v.17, p.19-48, Apr. 1989.

78. GONDIM, P.P.C. Estudo cefalométrico longitudinal do arescimento vertical da face em jovens leucodermas brasileiros dos 6 aos 18 anos. Bauru, 1999. 148p. Tese (Doutorado) - Faculdade de Odontologia de Bauru, Universidade de São Paulo.

79. GRABER,T.M. Clinical cephalometric analysis. In: KRAUS, B.S. \& RIEDEL, R.A. Vistas in orthodontics. Philadelphia, Lea \& Febinger, 1962, p.162-87.

80. GRESHAM, H.A. A cephalometric comparison of some skeletal and denture pattern components in two groups of children with acceptable occlusions. Angle Orthodont., v.33, n.2, p.114-9, Apr. 1963.

81. GURGEL, J.A. Estudo cefalométrico comparativo das alterações maxilomandibulares entre jovens, do sexo masculino, com má oclusão de Classe II, 1 $1^{\text {a }}$ divisão tratados ortodonticamente e com oclusão normal. Bauru, 1999. 163p. Tese (Doutorado) - Faculdade de Odontologia de Bauru, Universidade de São Paulo.

82. HELlMAN, M. Preliminary study in the development of the human face. Dental Cosmos, v.69, p.250-69, 1927.

83. HELMANN, M. An introduction to growth of the human face from infancy to adulthood. Int. J. Orthodont., v.18, p.777-98, 1932.

84. HELMANN, M. Changes in the human face brought about by development. Int. J. Orthodont., v.13, p.475-516, 1927. 
85. HELMANN, M. The face in its developmental career. Dental Cosmus, v.77, p.685-99, 777-87, 1935.

86. HENRIQUES, J.F.C. Estudo cefalométrico da ação da ancoragem extrabucal cervical, na dentadura mista, sobre a maxila, mandíbula e dentes, em pacientes com classe II, divisão 1. Bauru, 1979. 71p. Dissertação (Mestrado) Faculdade de Odontologia de Bauru, Universidade de São Paulo.

87. HENRIQUES, J.F.C.; FREITAS, M.R. Determinação da medida Wits em jovens brasileiros melanodermas com “ oclusão normal” e comparação com a dos jovens brasileiros leucodermas. Ortodontia, v.23, n.2, p.4-10, Mai/Ago. 1990.

88. HENRIQUES, J.F.C.; FREITAS, M.R.; HAYASAKI, S.M. Principais indicações da ancoragem extrabucal occipital (I.H.G.) no tratamento de jovens com má oclusão de Classe II, $1^{\text {a }}$ divisão de Angle: apresentação de um caso clínico. Rev. Dental Press Ortod. Ortop. Fac., v.4, n.2, p.33-8, Mar./Abr. 1999.

89. HERZBERG, F.; HOLIC, R. An anthropologic study of face height. . Amer. J. Orthodont. Oral Surg., v.29, p.90-100, 1943.

90. HOFRATH, H. Die bedeutung der röntgenfern und abstandsaufnahmen für die diagnostik der kiefenanomalien. Fortshc. Orthodont., v.2, p.232-58, 1931 apud ESTRIPEAUT LOPEZ, L.E. Estudo longitudinal do conceito de proporcionalidade da análise quadrangular de Di Paolo e sua aplicação em jovens adolescentes brasileiros, leucodermas, de origem mediterrânea e com oclusão normal. Dissertação (Mestrado). Faculdade de Odontologia de Bauru, Universidade de São Paulo. Bauru, 111p.

91. HORN, A.J. Facial height index. Amer. J. Orthodont. Orthop. Dentofac., v.102, n.2, p.180-6, Aug. 1992. 
92. HUltGREN, B.W. et al. Mechanics, growth, and class II corrections. Amer. J. Orthodont., v.74, n.4, p.388-95, Oct. 1978.

93. HUNPHREY, G. On the growth of the jaws. Trans. Of the Cambridge Phil. Society. Cambridge, $1^{\text {a }}$ ed., 1864. apud BRODIE, A.G. On the growth pattern of human head from the third month to the eight years. Am. J. Anat., v.68, p.209-62, 1941.

94. HUNTER, J. Natural history of the human teeth. London, 1771 apud BRODIE, A.G. On the growth pattern of human head from the third month to the eight years. Am. J. Anat., v.68, p.209-62, 1941.

95. INTERLANDI, S. Linha "I" na análise morfodiferencial para o diagnóstico ortodôntico. Rev. Fac. Odont. USP, v.9, n.2, p.289-310, Jul./Dez. 1971.

96. ISAACSON, J.R. et al. Extreme variation in vertical facial growth and associated variation in skeletal and dental relations. Angle Orthodont., v.41, n.3, p.21929, Jul. 1971.

97. ISAACSON, R.J. et al. Atualidades em Ortodontia. Ed. Premier. São Paulo.

98. ITO, K.; SUEMATSU, H. Cephalometrical study on the profile of Japanese young adult females with normal occlusion. Nippon Kyosei Shika Gakkai Zasshi, v.26, n.1, p.35-41, June 1967.

99. IWASAWA, T.; MORO, T.; NAKAMURA, K. Tweed triangle and soft-tissue consideration of japanese with normal occlusion and good facial profile. Amer. J. Orthodont., v.72, n.2, p.119-27, Aug. 1977.

100. JACOBSON, A. The craniofacial skeletal pattern of the south African Negro. Amer. J. Orthodont., v.73, n.6, p.544-56, June 1978. 


\section{ReferêndiasBibliográficas}

101. JANSON, G.R.P.; MARTINS, D.R. Estudo longitudinal e comparativo do crescimento facial dos 13 aos 18 anos de idade em jovens brasileiros leucodermas, utilizando a análise cefalométrica de McNamara Jr. Bauru, 1990. 138p. Tese (Doutorado)- Faculdade de Odontologia de Bauru, Universidade de São Paulo.

102. JANSON, G.R.P.; METAXAS, A.; WOODSIDE, D.G. Variations in maxillary and mandibular molar and incisor vertical dimension in 12-years-old subjects with excess, normal, and short lower anterior face height. Amer. J. Orthodont. Orthop. Dentofac., v.106, n.4, p.409-18, Oct. 1994.

103. JOHNSON, E.L. The Frankfort- Mandibular plane angle and the facial pattern. Amer. J. Orthodont., v.36, p.516-33, 1950.

104. JONES, B.H.; MEREDITH, H.V. Vertical change in osseous and odontic portions of human face height between the ages of 5 and 15 years. Angle Orthodont., v.52, n.12, p.902-21, Dec. 1966.

105. KAMITSUJI, I.K.N. Estudo cefalométrico dos efeitos do uso do aparelho extrabucal tipo I.H.G., em pacientes portadores de má-oclusão de classe II divisão $1^{a}$ de Angle. São Paulo, 1998. 155p. Monografia (Especialização) Instituto de Ciências da Saúde, Universidade Paulista.

106. KARLSEN, A.T. Craniofacial growth differences between low and high MP-SN angle males: a longitudinal study. Angle Orthodont., v.65, n.5, p.341-50, Sept. 1994.

107. KERR, W.J.S.; LANFORD, B.S. The variability of some craniofacial dimensions. Angle Orthodont., v.61, p.205-10, 1991. 
108. KILLIARIDIS, S. et al. The relationship between maximal bite force, bite force endurence and facial morphology during growth. A cross-sectional study. Acta Odontol. Scand., v.51, p.323-31, 1993.

109. KIM, K.R.; MUHL, Z.F. Changes in mandibular growth direction during and after cervical headgear treatment. Amer. J. Orthodont. Orthop. Dentofac., v.119, n.5, p.522-30, May. 2001.

110. KING, E.W. Cervical anchorage in ClassII, division 1 treatment, a cephalometric appraisal. Angle Orthodont., v.27, p.98-104, 1957.

111. KLAPPER, L. et al. The influence of extraction and nonextraction orthodontic treatment on brachyfacial and dolichofacial growth patterns. Amer. J. Orthodont. Orthop. Dentofac., v.101, n.5, p.425-30, May. 1992.

112. KOCADERELI, I. The effect of first premolar extraction on vertical dimension. Amer. J. Orthodont. Orthop. Dentofac., v.116, n.1, p.41-5, Jul. 1999.

113. KROGMAN, W.M. The problem of the growth changes in the face and skull as viewed from comparative study of anthropoids and man. Dental Cosmos, v.72, p.624-30, 1930.

114. KROGMAN, W.M., SASSOUNI, V. A syllabus in roentgenographic cephalometric. 2.ed. Philadelphia, College Offset, 1957, p.45-103 apud JANSON, G.R.P.; MARTINS, D.R. Estudo longitudinal e comparativo do crescimento facial dos 13 aos 18 anos de idade em jovens brasileiros leucodermas, utilizando a análise cefalométrica de McNamara Jr. Bauru, 1990. 138p. Tese (Doutorado)- Faculdade de Odontologia de Bauru, Universidade de São Paulo.

115. KROGMAN, W.M. Biological timing and the dentofacial complex. Part III. J. Dent. Child., v.35, p.377-81, 1968. 
116. LANDE, M.J. Growth behavior of the human body facial profile as revealed by serial cephalometric roentgenology. Angle Orthodont., v.22, p.78-90, 1952.

117. LIGTHELM-BAKKER, A.S.W.M.R. et al. Vertical growth of the anterior face: a new approach. Amer. J. Orthodont. Orthop. Dentofac., v.101, n.6, p.509-13, Jun. 1992.

118. LIN, J.K. Roentgen cephalometric study on craniums of Formosan and Japanese adults. 2 standard values for various cephalometric analysis. Shikwa Gakuho, v.78, n.6, p.951-9, 1978.

119. LINDER-ARONSON, S.; WOODSIDE, D.G. Excess face height malocclusion: etiology, diagnosis, and treatment. Chicago, Quintessence Publishing Co., 2000.

120. LOCKS, A. Análise das proporções verticais anteriores da face de indivíduos brasileiros, portadores de oclusão excelente e perfil agradável. Rio de Janeiro, 1981. 69p. Dissertação (Mestrado)- Faculdade de Odontologia, Universidade Federal do Rio de Janeiro.

121. LOCKS, A. Estudo cefalométrico das alturas faciais anterior e posterior, em crianças brasileiras, portadoras de má oclusão Classe I de Angle, na fase de dentadura mista. Araraquara, 1996. 128p. Tese (Doutorado)- Faculdade de Odontologia de Araraquara- UNESP.

122. LUNA, M.S. \& BLAHA, L. La odontología en funcion de la estetica. Rev. Fac. Odontol. (San Miguel de Tucuman), v.12, p.39-42, 1978 apud CARDOSO, S.M.O. Estudo da estética facial visando à confecção das próteses faciais. Dissertação (Mestrado), Faculdade de Odontologia, Universidade de São Paulo, 238p., São Paulo, 1990. 


\section{ReferêndiasBibliográficas}

123. LUSTERMAN, E.A. The esthetics of the occidental face: a study of dentofacial morphology based upon anthropologic criteria. Amer. J. Orthodont., v.19, p.826-50, 1963.

124. MAGGIONCALDA, E.A. Treatment of a Class II, division 1 vertical growth pattern with severe anterior crowding. Amer. J. Orthodont. Dentofac. Orthop., v.112, n.4, p.300-8, Oct. 1997.

125. MALTAGLIATI, L.A. et al. Estudo comparativo das alterações dentoesqueléticas da má oclusão de classe II, $1^{\text {a }}$ divisão de Angle, nos jovens sem tratamento e nos submetidos a dois tipos de aparelhos ortodônticos. Rev. Odontol. Univ. São Paulo, v.13, n.4, p.407-16, out./dez. 1999.

126. MARGOLIS, H.I. A basic facial pattern and its application in clinical orthodontics. Amer. J. Orthodont. Oral Surg., v.33, n.10, p.631-41, Oct. 1947.

127. MARTINS, D.R. et al. Atlas de crescimento craniofacial. 1.ed. São Paulo, Ed. Santos, 1998.

128. MARTINS, D.R. Estudo comparativo dos valores cefalométricos das análises de Downs, Tweed, Steiner e Alabama, com os de adolescentes brasileiros, leucodermas, de origem mediterrânea. Bauru, 1979. 141p. Tese (Livre Docência) - Faculdade de Odontologia de Bauru, Universidade de São Paulo.

129. MARTINS, N.S.; VIGORITO, J.W. Estudo dos valores cefalométricos da análise de Björk, em adolescentes brasileiros, leucodermas, portadores de oclusão normal. Ortodontia, v.20, n.1/2, p.18-38, 1987.

130. MASAKI, F. The longitudinal study of morphological differences in the cranial base and facial structure between Japanese and American white. Nippon Kyosei Shika Gakkai Zasshi, v.39, n.4, p.436-56, 1980. 


\section{Referêndas Bibliográficas}

131. MATOS, E.B. Análise de Tweed - individualização para uma comunidade de brasileiros. Rio de Janeiro, 1980.72p. Dissertação (Mestrado) - Faculdade de Odontologia da Universidade Federal do Rio de Janeiro.

132. MCLAUGHLIN, R.P.; BENNETT, J.C. The extraction-nonextraction dilemma as it relates to TMD. Angle Orthodont., v.65, n.3, p.175-86, Jan./Fev. 1995.

133. MCNAIR, R.W. A cross-sectional study of vertical facial dimensions of children with excellent occlusions. Master of science thesis, University of Washington, Seattle, Washington, 1953 apud BAUM, A.T. Age and sex differences in the dentofacial changes following orthodontic treatment, and their significance in treatment planning. Amer. J. Orthodont., v.47, p.355-70, 1961.

134. MCNAMARA JÚNIOR,.A. An experimental study of increased vertical dimension in the growing face. Amer. J. Orthodont., v.71, n.4, p.382-95, Apr. 1977.

135. MCNAMARA JÚNIOR, J.A. A method of cephalometric evaluation. Amer. J. Orthodont., v.86, n.6, p.449-69. Dec. 1984.

136. MEDEIROS, M.A.Q.B.; HENRIQUES, J.F.C.; FREITAS, M.R. Estudo cefalométrico do padrão dentário de jovens brasileiros melanodermas do sexo feminino, com “ oclusão normal”. Ortodontia, v.2, n.1, p.34-48, Jan./Jun. 1988.

137. MEREDITH, H.V.; KNOTT, V.B.; HIXON, E.H. Relation of the nasal and subnasal components of facial height in childhood. Amer. J. Orthodont., v.43, n.5, p.285-94, Apr. 1958.

138. MEROW, W.A. A cephalometric statistical appraisal of dentofacial growth. Angle Orthodont., v.32, p.205-13, Oct. 1962. 


\section{ReferênaiasBibliográficas}

139. MERRIFIELD, L.L. Analysis - concepts and values. Part II. J. Charles H. Tweed Found., v.17, p.49-64, Apr. 1989.

140. MIURA, F.; INOUE, N.; SUZUKI, K. The standards of Steiner's analysis for japanese. Bull. Med. And Dent. Univ., v.10, p.387-95, 1963.

141. MIURA, F.; INOUE, N.; SUZUKI, K. Cephalometric standards for japanese according to the Steiner analysis. Amer. J. Orthodont., v.51, n.4, p.288-95, 1965.

142. MIYAJIMA, K. et al. Craniofacial structure of Japanese and European-American adults with normal occlusion and well-balanced faces. Amer. J. Orthodont. Dentofac. Orthop., v.110, n.4, p.431-8, Oct. 1996.

143. MOORE, A.W. Observations on facial growth and its clinical significance. Amer. J. Orthodont., v.45, n.6, p.399-423, Jun. 1959.

144. MORAES, C.; FREITAS, M.R.; HENRIQUES, J.F.C. Cefalometria: determinação do padrão esquelético das adolescentes melanodermas brasileiras com "oclusão normal". Ortodontia, v.22, n.2, p.4-14, Jul./Dez. 1988.

145. MOYERS, R.E. et al. Differential diagnosis of Class II malocclusions. Part 1Facial types associated with Class II malocclusions. Amer. J. Orthodont., v.78, n.5, p.477-94, Nov. 1980.

146. MOYERS, R.E. Técnicas ortodônticas. In: Ortodontia. 4.ed. Rio de Janeiro, Guanabara Koogan, c1991. Cap.18, p.438-79.

147. NAHOUM, H.I. Vertical proportions and the palatal plane in anterior open-bite. Amer. J. Orthodont., v.59, n.3, p.273-82, Mar. 1971. 
148. NAHOUM, H.I. et al. Varieties of anterior open-bites. Amer. J. Orthodont., v.61, n.5, p.486-92, May 1972.

149. NANDA, S.K. Patterns of vertical growth in the face. Amer. J. Orthodont. Dentofac. Orthop. v.93, n.2, p.103-16, Feb. 1988.

150. NANDA, S.K.; TANEJA, R.C. Growth of the face during the transitional period. Angle Orthodont., v.42, p.165-71, 1972.

151. NELSON, B.; HANSEN, K.; HÄGG, U. Overjet reduction and molar correction in fixed appliance treatment of Class II, Division 1, malocclusions: sagittal and vertical components. Amer. J. Orthodont. Orthop. Dentofac., v.115, n.1, p.13-23, Jan. 1999.

152. NIELSEN, I.L. Vertical malocclusions: etiology, development, diagnosis and some aspects of treatment. Angle Orthodont., v.61, n.4, p.247-60, Oct./Dec. 1991.

153. ORTIAL, J.P. Vertical dimension and therapeutic choices. Amer. J. Orthodont. Dentofac. Orthop., v.108, n.4, p.432-41, Oct. 1995.

154. OUVRARD, M.J. Réflexion sur deux préoccupations journaliére de l'odontologie: la douler et la beauté. Bull. Acad. Dent., v.8, p.31-45, 1964 apud CARDOSO, S.M.O. Estudo da estética facial visando à confecção das próteses faciais. Dissertação (Mestrado), Faculdade de Odontologia, Universidade de São Paulo, 238p., São Paulo, 1990.

155. PAQUETTE, D.E.; BEATTIE, J.R.; JOHNSTON JUNIOR, L.E. A long term comparison of nonextraction and premolar extraction edgewise therapy in "borderline" class II patients. Amer. J. Orthodont. Dentofac. Orthop., v.102, n.1, p.1-14, July 1992. 


\section{Referêndas Bibliográficas}

156. PEARSON, L.E. Vertical control in treatment of patients having backwardrotational growth tendencies. Angle Orthodont., v.48, n.2, p.132-40, Apr. 1978.

157. PEARSSON, L.E. Vertical control through use of mandibular posterior intrusive forces. Angle Orthodont., v.43, n.2, p.194-200, Apr. 1973.

158. PECK, H.; PECK, S. A concept of facial esthetics. Angle Orthodont., v.40, n.4, p.284-317, 1970.

159. PECK, S. Relevância da Estética Facial na Ortodontia. Secção II- p.63-116, Ed. Premier. São Paulo, 1997.

160. PERRY, H.T. Adolescent temporomandibular dysfunction. Amer. J. Orthodont., v.63, p.517-25, 1973.

161. PERSSON, M.; PERSSON, E.C.; SKAGIUS, S. Long-term spontaneous changes following removal of all first premolars in Class I cases with crowding. Eur. J. Orthodont., v.11, n.3, p.271-82, Aug. 1989.

162. PETRAITIS, B.J. A cephalometric study of excellent occlusion and Class I malocclusion of children and adults. Washington, 1951. Thesis - University of Washington apud BAUM, A.T. Age and sex differences in the dentofacial changes following orthodontic treatment, and their significance in treatment planning. Amer. J. Orthodont., v.47, p.355-70, 1961.

163. PINTO, N.; WOODS, M.; CRAWFORD, E. Vertical facial pattern and orthodontic stability. Part I: pretreatment vertical pattern and stability. Aust. Orthodont. J., v.16, n.3, p.127-32, Nov. 2000.

164. PROFFIT, W.R. Concepts of physical growth and development. In: Contemporary orthodontics. Saint Louis, Mosby, p.16-38, 1986. 
165. RADDI, I.M.G.; HENRIQUES, J.F.C.; MARTINS, D.R. Determinação da linha "I" em xantodermas nipo-brasileiros, dos 12 aos 18 anos e 6 meses, com "oclusão normal". Ortodontia, v.22, n.3, p.24-32, Set./Dez. 1989.

166. REDDY, P. et al. Skeletal and dental changes with nonextraction Begg mechanoterapy in patients with Class II division 1 malocclusion. Amer. J. Orthodont. Dentofac. Orthop., v.118, n.6, p.641-8, Dec. 2000.

167. REZENDE, H.S.G.; TELLES, C.S. Análise de Downs: individualização para uma comunidade de brasileiros. Ortodontia, v.17, n.1/3, p.15-28, jan./dez. 1984.

168. RICHARDSON, A. Skeletal factors in open-bite and deep overbite. Amer. J. Orthodont., v.56, n.2, p.114-27, Aug. 1969.

169. RICKETTS, R.M. The biologic significance of the divine proportion and Fibonacci series. Amer. J. Orthodont., v.81, n.5, p.351-70, May 1982.

170. RICKETTS, R.M. The golden diviner. J.Clin. Orthodont., v.11, n.15, p.752-9, Nov. 1981.

171. RICKETTS, R.M. The influence of orthodontic treatment on facial growth and development. Angle Orthodont., v.30, n.3, p.103-33, July 1960.

172. RICKETTS, R.M. Cephalometric analysis and synthesis. Angle Orthodont. v.31,n.3, p.141-56, July 1961.

173. SAKIMA, T. Estudo comparativo do tipo de oclusão dentária entre japoneses originários da ilha de Okinawa e japoneses originários das demais ilhas. Araraquara, 1976. 52p. Tese (Livre-docência)- Faculdade de Odontologia de Araraquara- UNESP. 


\section{Referêndias Bibliográficas}

174. SANKEY-W.L. et al. Early treatment of vertical skeletal dysplasia: the hyperdivergent phenotype. Amer. J. Orthodont. Orthop. Dentofac., v.118, n.3, p.317-27, Sept. 2000.

175. SANSOY, L.T.; DARENDELILER, N. The influence of extraction orthodontic treatment on craniofacial structures: evaluation according to two different factors. Amer. J. Orthodont. Orthop. Dentofac., v.115, n.5, p.508-14, May 1999.

176. SASSOUNI, V. A classification of skeletal facial types. Amer. J. Orthodont., v.55, n.2, p.109-23, Feb. 1969.

177. SASSOUNI, V. The Class II syndrome: differential diagnosis and treatment. Angle Orthodont., v.40, n.4, p.334-41, Oct. 1970.

178. SASSOUNI, V.; NANDA, S. Analysis of dentofacial vertical proportions. Amer. J. Orthodont., v.50, n.11, p.801-23, Nov. 1964.

179. SCAVONE JR., H.; FREITAS, M.R.; HENRIQUES, J.F.C. Estudo cefalométrico longitudinal das alterações no perfil facial tegumentar, posteriores ao tratamento ortodôntico, em jovens leucodermas do sexo masculino. Ortodontia, v.26, n.1, p.38-69, Jan/ Abr. 1993.

180. SCHENDEL, S.A. et al. The long face syndrome: vertical maxillary excess. Amer. J. Orthodont., v.70, n.4, p.398-408, Oct. 1976.

181. SCHIAVON GANDINI, M.R.E.A. et al. Effects of cervical headgear and edgewise appliances on growing patients. Amer. J. Orthodont. Orthop. Dentofac., v.119, n.5, p.522-39, May 2001.

182. SCHUDY, F.F. The control of vertical overbite in clinical orthodontics., Angle Orthodont., v.38, n.1, p.19-39, Jan. 1968. 
183. SCHUDY, F.F. The rotation of the mandible resulting from growth: its implications in orthodontic treatment. Angle Orthodont., v.35, n.1, p.36-50, Jan. 1965.

184. SCHUDY, F.F. Vertical growth versus anteroposterior growth as related to function and treatment. Angle Orthodont., v.34, n.2, p.75-93, Apr. 1964.

185. SCOTT, J.H. The analysis of facial growth. Amer. J. Orthodont., v.44, p.507-12, 1958.

186. SIRIWAT, P.P.; JARABAK, J.R. Malocclusion and facial morphology. Is there a relationship? - an epidemiologic study. Angle Orthodont., v.55, n.2, p.127-38, Apr. 1985.

187. SHISHIKURA, K. The study on measurements of hard and soft tissues by cephalograms - particularly on normal and Class I occlusion among Japanese adults. Nippon Kyosei Shika Gakkai Zasshi, v.28, n.2, Dec. 1969.

188. SHULTZ, J.D. A serial cephalometric study of children at twelve and sixteen years of age having excellent occlusions. Washington, 1955. Thesis University of Washington apud BAUM, A.T. Age and sex differences in the dentofacial changes following orthodontic treatment, and their significance in treatment planning. Amer.J.Orthodont., v.47, p.355-70, 1961.

189. SMITH, W.S. Ancient Egypt. Boston, Beacon Press, p.15-35, 1961 apud PECK, H.; PECK, S. A concept of facial esthetics. Angle Orthodont., v.40, n.4, p.284$317,1970$.

190. SOLNICA, S. L'harmonie dento-faciale selon les artistes de la Renaissance. Rev. Odonto-Stomat., v.3, n.1, p.27-37, jan./fev. 1974. 


\section{ReferênaiasBibliográficas}

191. SPYROPOULOS, M.N.; ASKARIEH, M. Vertical control: a multifactorial problem and its clinical implications. Amer. J. Orthodont., v.70, n.1, p.70-80, Jul. 1976.

192. STAGGERS, J.A. A comparison of results of second molar and first premolar extraction treatment. Amer. J. Orthodont. Orthop. Dentofac., v.98, n.5, p.430-6, Nov. 1990.

193. STAGGERS, J.A. Vertical changes following first premolar extractions. Amer. J. Orthodont. Orthop. Dentofac., v.105, n.1, p.19-24, Jan. 1994.

194. SUBTELnY, J.D.; SAKUDA, M. Open-bite: diagnosis and treatment. Amer. J. Orthodont., v.50, n.5, p.337-58, May 1964.

195. SUBTELNY, J.D. Cephalometric diagnosis, growth and treatment changes. Angle Orthodont., v.57, p.262-86, 1970.

196. TAKAHASHI, R. Padrão cefalométrico FOB-USP para jovens nipo-brasileiros e portadores de oclusão normal. Bauru, 1998. 133p. Dissertação (Mestrado) Faculdade de Odontologia de Bauru, Universidade de São Paulo.

197. TANAKA, O.M. As proporções faciais verticais anteriores em leucodermas brasileiros adultos com oclusão excelente e perfil facial agradável. Rio de Janeiro, 1990. 58p. Dissertação (Mestrado)- Universidade Federal do Rio de Janeiro.

198. TANER-SANSOY, L.; DARENDELILER, N. The influence of extraction orthodontic treatment on craniofacial structures: evaluation according to two different factors. Amer. J. Orthodont. Dentofac. Orthop., v.115, n.5, p.50814, May 1999. 


\section{ReferêndiasBibliográficas}

199. THOMPSON, J.R.; BRODIE, A.G. Factors in the position of he mandible. Amer. J. Orthodont., v.29, p.925-41, 1942.

200. TIRK, T.M. A study of the growth of the head by planimetric method. Angle Orthodont., v.17, p.76-94, 1948.

201. TODD, T.W. The orthodontic value of research and observations in developmental growth of the face. Angle Orthodont., v.51, p.92, 1981.

202. TUlLEY, W.J. The role of extractions in orthodontic treatment. Brit. Dent. J., v.107, n.8, p.199-205, Oct. 1959.

203. TWEED, C.H. Indications for the extraction of teeth in orthodontic procedure. Amer. J. Orthodont. Oral Surg.,v.30, p.405-28, 1944.

204. UESATO, G. Esthetic facial balance of American-japanese. Amer. J. Orthodont., v.54, n.8, p.601-11, 1968.

205. VADEN, J.L. Nonsurgical treatment of the patient with vertical discrepancy. Amer. J. Orthodont. Orthop. Dentofac., v.113, n.5, p.567-82, May 1998.

206. VADEN, J.L.; HARRIS, E.F.; SINCLAIR, P.M. Clinical ramifications of posterior and anterior facial height chages between treated and untreated class II samples. Amer. J. Orthodont. Dentofac. Orthop., v.105, n.5, p.438-43, May 1994.

207. VAN DER BEEK, M.C.J.; HOEKSMA, J.B.; PRAHL-ANDERSEN, B. Vertical facial growth: a longitudinal sudy from 7 to 14 years of age. Eur. J. Orthodont., v.13, p.202-8. 1991.

208. VILLALOBOS, F.J.; SINHA, P.K.; NANDA, R.S. Longitudinal assessment of vertical and sagittal control in the mandibular arch by the mandibular fixed 
lingual arch. Amer. J. Orthodont. Orthop. Dentofac., v.118, n.4, p.366-770, Oct. 2000.

209. WARD, D.M. Angle class II, division 1 malocclusion. Amer. J. Orthodont. Dentofac. Orthop., v.106, n.4, p.428-33, Oct. 1994.

210. WEINBERG, H.; KRONMAN, J.H. Orthodontic influence upon anterior facial height. Angle Orthodont., v.36, n.1, p.80-8, Jan. 1966.

211. WIESLANDER, L. The effect of orthodontic treatment on the concurrent development of craniofacial complex. Amer. J. Orthodont., v.49, n.1, 15-27, Jan. 1963.

212. WILLIAMS, B.H. Craniofacial proportionality in a horizontal and vertical plane, a study in norma lateralis. Angle Orthodont., v.23, n.1, p.26-34, Jan. 1953.

213. WYATT, W.E. Preventing adverse effects on the temporomandibular joint through orthodontic treatment. Amer. J. Orthodont. Dentofac. Orthop., v.91, n.6, p.493-9, Jun. 1987.

214. WYLIE, W.L. Statistical analysis of the constancy of certain facial dimensions. J. Dent. Res., v.22, p.200-1, 1944.

215. WYLIE, W.L. The relationship between ramus height, dental height, and overbite. Amer. J. Orthodont. Oral Surg., v.32, n.2, p.57-67, Feb. 1946.

216. WYLIE, W.L.; JOHNSON, E.L. Rapid evaluation of facial dysplasia in the vertical plane. Angle Orthodont., v.22, n.3, p.165-82, July 1952.

217. YAMAGUCHI, K.; NANDA, R.S. The effects of extraction and nonextraction treatment on the mandibular position. Amer. J. Orthodont. Orthop. Dentofac., v.100, n.5, p.443-52, Nov. 1991. 


\section{Referências Bibliográficas}

218. YAMAUCHI, K. et al. Sex difference of Japanese adult profile with normal occlusion on cephalometric roentgenograms. Nippon Kyosei Shika Gakkai Zasshi, v.26, n.2, p.155-60, Dec. 1967.

219. YEN, P.K.J. The facial configuration in a sample of Chinese boys. Angle Orthodont., v.43, n.3, p.301-4, July 1973.

220. ZAHER, A.; BISHARA, S.E.; JAKOBSEN, J.R. Posttreatment changes in different facial types. Angle Orthodont., v.64, n.6, p.425-36, Nov./Dez. 1994. 


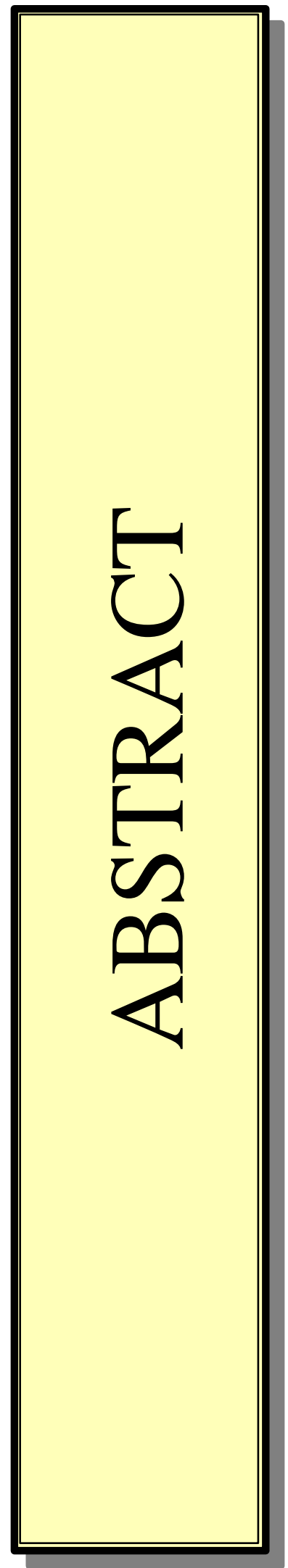




\section{Abstract}

The objective of this retrospective longitudinal cephalometric investigation was to study the influence of extraction and nonextraction orthodontic treatment on the facial height japanese children and grandchildren with Class I and Class II, Division 1 malocclusions. The sample included 59 mesocephalic subjects distributed in to 4 groups: group I- Class I treated with first bicuspid extractions (9 males and 6 females); group II- Class I treated without extraction (8 males and 7 females); group III- Class II, Division 1 treated with first bicuspid extractions (7 males and 7 females); group IVClass II, Division 1 treated without extraction (7 males and 8 females). The initial mean age was 12.14 years and all groups were treated with the Edgewise simplified technique, during a mean period of 2.49 years. The resulted changes were compared by the ANOVA. There were no statistically significant differences ( $p \quad 0,05)$ in the first bicuspid extractions orthodontic treatment when compared to the nonextraction treatment in both Class I and Class II, Division 1. The $\mathrm{t}$ test showed that extraction treatment in Class I and II (groups I and III) is associated with a significant increase in the Horn index and PFH/AFH ratio. In addition, FMA and SN.GoGn did not change statistically. No sexual dimorphism was encountered for the anterior and posterior facial height changes, except for some dentoalveolar measurements (U6-PTV and L6-PTV) in Group I, where males achieved higher values than females. In group III, greater changes in L6-MP, PFH and S-Go were also demonstrated by male patients. 


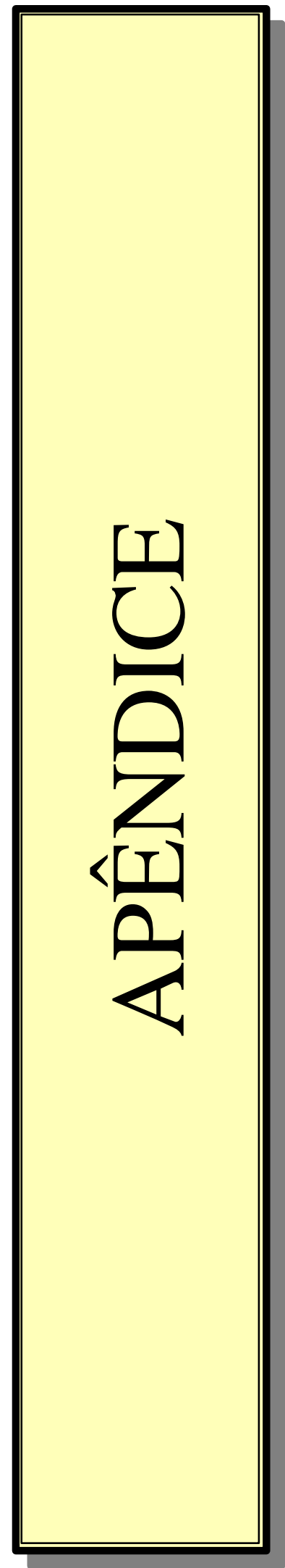

